\title{
OTEC Advanced Composite Cold Water Pipe: Final Technical Report
}

Work sponsored by the US Department of Energy and performed by Lockheed Martin Corporation and its subcontractors under DoE / LM MS2 Cooperative Agreement \# DE-FC36-08G018172. Includes other related work for completeness.

Dr. Alan K. Miller

LMSSC-ATC

Principal Investigator and CWP sub-system lead Mr. Matt Ascari

LM MS2

Program Manager

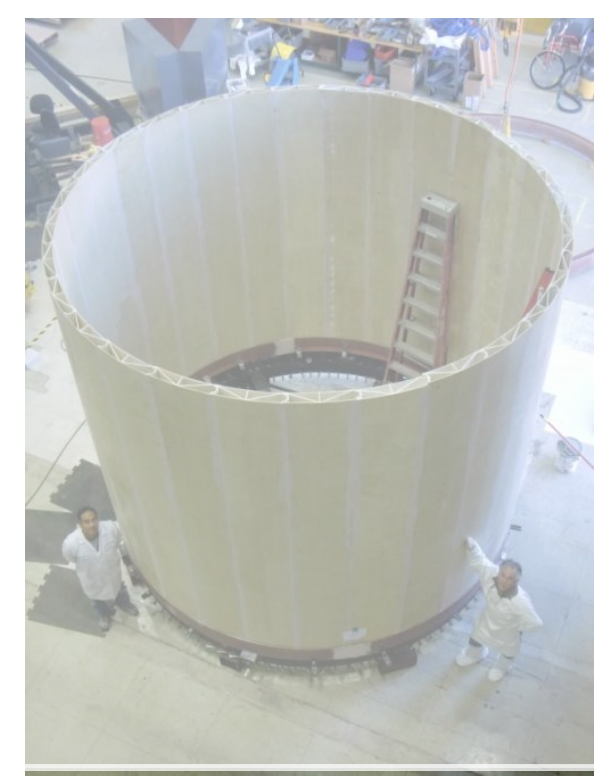

Rev. L, Sept. 4, 2011

Status: All slides released, LM PIRA \#MAN201104003 


\section{Abstract and 1-page Executive Summary}

Ocean Thermal Energy Conversion can exploit natural temperature gradients in the oceans to generate usable forms of energy (for example, cost-competitive baseload electricity in tropical regions such as Hawaii) free from fossil fuel consumption and global warming emissions.

The \#1 acknowledged challenge of constructing an OTEC plant is the Cold Water Pipe (CWP), which draws cold water from 1000m depths up to the surface, to serve as the coolant for the OTEC Rankine cycle. For a commercial-scale plant, the CWP is on the order of 10m in diameter. This report describes work done by LMSSC developing the CWP for LM MS2 New Ventures' emerging OTEC business. The work started in early 2008 deciding on the minimum-cost CWP architecture, materials, and fabrication process. In order to eliminate what in previous OTEC work had been a very large assembly/deployment risk, we took the innovative approach of building an integral CWP directly from the OTEC platform and down into the water. During the latter half of 2008, we proceeded to a successful small-scale Proof-of-Principles validation of the new fabrication process, at the Engineering Development Lab in Sunnyvale.

During 2009-10, under the Cooperative Agreement with the US Dept. of Energy, we have now successfully validated key elements of the process and apparatus at a $4 \mathrm{~m}$ diameter scale suitable for a future OTEC Pilot Plant. The validations include:

-Assembly of sandwich core rings from pre-pultruded hollow "planks," holding final dimensions accurately

-Machine-based dispensing of overlapping strips of thick fiberglass fabric to form the lengthwise-continuous face sheets, holding accurate overlap dimensions

-Initial testing of the fabric architecture, showing that the overlap splices develop adequate mechanical strength (work done under a parallel US Naval Facilities Command program)

-Successful resin infusion/cure of $4 \mathrm{~m}$ diameter workpieces, obtaining full wet-out and a non-discernable knitline between successive stepwise infusions.

After an introductory section describing the background and initial work, the major sections of this report describe (mostly by graphical means) the results of these validations at $4 \mathrm{~m}$ scale. Within each section, the key results, evidence, and future improvements are summarized concisely in tables.

The last section of this report describes future plans to complete the CWP risk retirement and implementation.

An extended Executive Summary at the end provides the key results from this work at the level of one photo montage and one table per validation. 


\section{Contributors to this work}

- CWP subsystem lead and Principal Investigator: Alan Miller

- LM MS2 CWP Program Manager: Matt Ascari

- LM SSC CWP Program Manager: Nat Shankar

- Design: Chad Nevills, Patrick Quigley, Bobby Lane

- Stress analysis: Matt Nahan, Doug Hillson, Matthew Nahan, Greg Cuzner

- Manufacturing engineering: Herman DeVliegher

- Engineering Development Lab: Ted Rosario (chief CWP technician), Mike Garcia, Jose Tellez, Frank Phillips, Gene Evans, Gill Hennessee, Manny Martinez (lead)

- Control system wiring: Loretta Robinette, Tina Retana

- Janicki Industries (Paul VanSant, project manager)

- Owens Corning Technical Fabrics

- Glasforms, Inc.

- West Virginia Univ. (Prof. Hota Gangarao; David Dittenber)

- Initial strategic approach: Steve Bailey 


\section{Table of Contents}

I. OTEC and the Cold Water Pipe

II. The LM Advanced Composite Cold Water Pipe

A. Selection of configuration, materials, and fabrication strategy

B. Selection of fabrication method and details

III. Analyses to date of CWP structural behavior

IV. Proof-of-Principles validation of the CWP fabrication process

V. Design configuration of the full CWP fabrication apparatus

VI. Validation of the CWP fabrication process at $4 \mathrm{~m}$ diameter scale

A. Validation 1 - Core plank production and assembly into core rings

B. Validation 2 - Fabric architecture, production, overlap splice performance, and fabric dispensing process

1. Fabric architecture

2. Validation of overlap splice strength

3. Fabric dispensing validation

C. Validation 3 - Stepwise infusion molding process

1. Apparatus
a. Hard shells
b. Soft tools including Re-Usable Resin Distribution Line (RURDL)
c. Resin and resin handling elements
d. Acceptance testing at Janicki, transport to Sunnyvale, and installation in B/132 High Bay
e. Molding region control system

2. Initial validation workpiece
a. Layup and insertion into Molding Region
b. Infusion of workpiece
c. Results on infused workpiece
d. Validation of analytical tools for predicting infusion behavior

VII. Path forward

VIII. Executive Summary (including one-page graphical and tabular summaries of overall approach and each validation) 


\section{OJEC}

\section{OTEC and the Cold Water Pipe}

- OTEC

- Major OTEC plant components

- The Cold Water Pipe is (literally) the single biggest challenge of OTEC

- The checquered past of Cold Water Pipes for OTEC projects

- Prior attempts at building OTEC plants have been bedeviled by disasters constructing and deploying the Cold Water Pipe 
OTEC (Ocean Thermal Energy Conversion) is a renewable energy technology that can provide large quantities of baseload (24/7/365) electricity in tropical climates, for example in Hawaii and at overseas Navy bases. The key benefits are:

-No fossil fuel is required

-No greenhouse gasses are emitted 


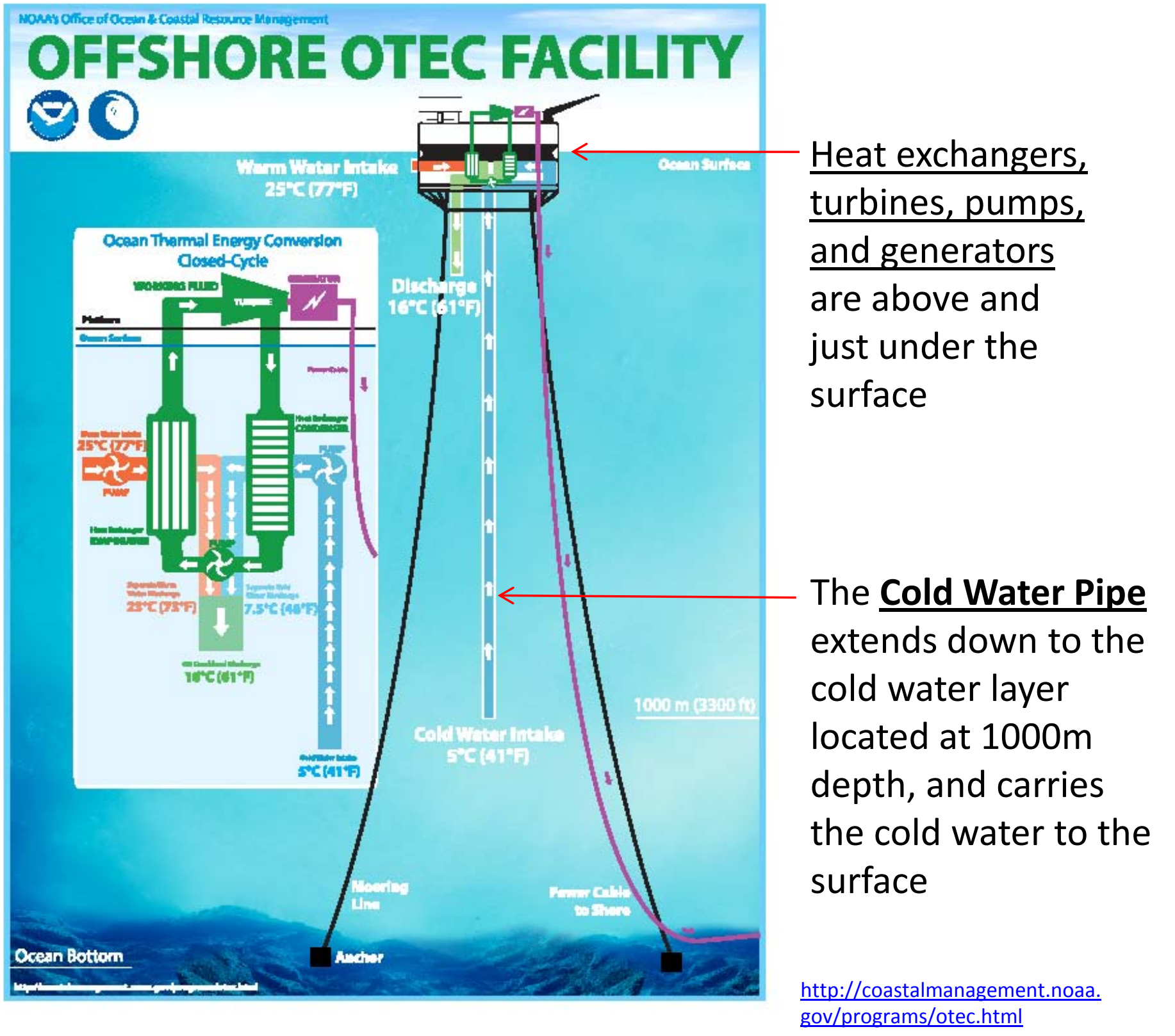




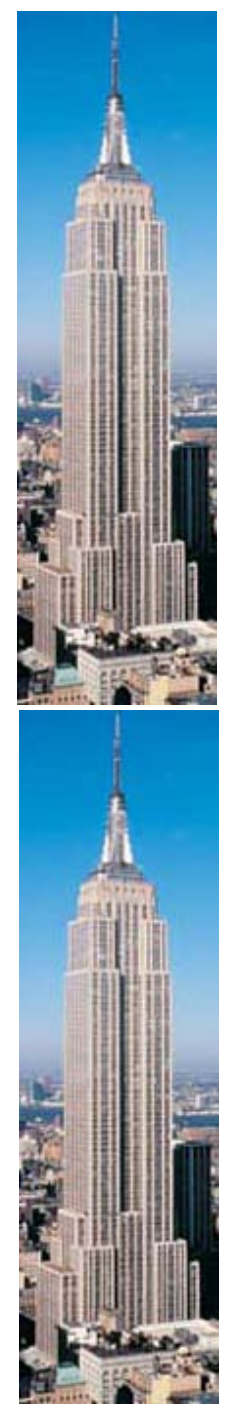

.by $10 \mathrm{~m} / 33 \mathrm{ft}$ in diameter

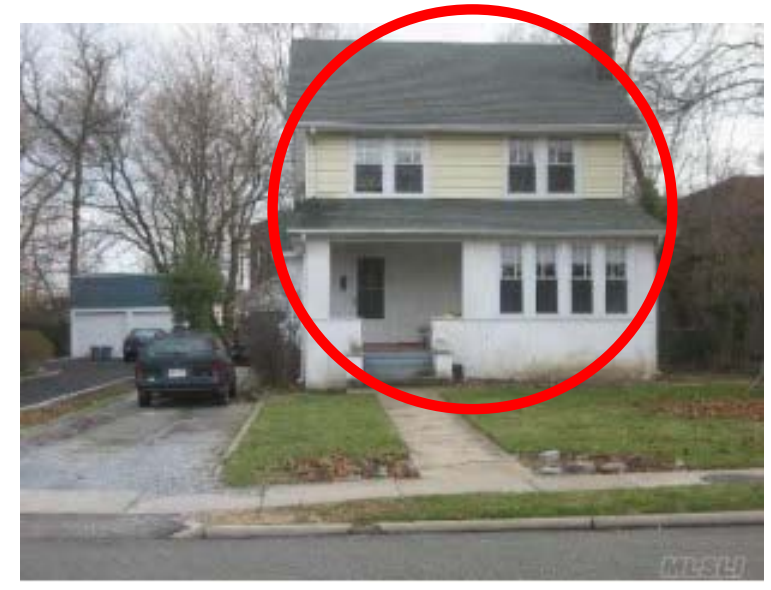

That is 2+

Empire

State

...and about the width of a modest

2-story house 


\section{The Checquered Past of Cold Water Pipes for OTEC projects}

\begin{tabular}{|c|c|c|c|c|}
\hline & Date & Diameter & CWP material & Results (CWP) \\
\hline $\begin{array}{l}\text { Claude - Cuba } \\
\text { (on-shore plant) }\end{array}$ & 1930 & $2 m$ & Corrugated steel sections & $\begin{array}{l}1^{\text {st }} 3 \text { attempts to deploy CWP } \\
\text { failed; } 4^{\text {th }} \text { was successful }\end{array}$ \\
\hline $\begin{array}{l}\text { Claude - Brazil } \\
\text { (plant ship) }\end{array}$ & 1935 & $2.4 \mathrm{~m}$ & Steel sections & $\begin{array}{l}\text { CWP broke off in a storm during } \\
\text { deployment; plant was abandoned }\end{array}$ \\
\hline Mini-OTEC & 1979 & $0.7 \mathrm{~m}$ & $\begin{array}{l}\text { HDPE (high density } \\
\text { polyethylene) }\end{array}$ & Successful \\
\hline $\begin{array}{l}\text { DoE sub-scale } \\
\text { CWP test (OTEC-1) }\end{array}$ & 1983 & $\begin{array}{l}2.4 \mathrm{~m} x \\
122 \mathrm{~m} \text { long }\end{array}$ & $\begin{array}{l}\text { Fiberglass face sheet / foam } \\
\text { core sandwich sections }\end{array}$ & Successful \\
\hline $\begin{array}{l}\text { Japan (Nauru; } \\
\text { shore-based demo) }\end{array}$ & 1981 & $0.7 \mathrm{~m}$ & HDPE & $\begin{array}{l}\text { Built; operated; a hurricane wiped } \\
\text { out the facility }\end{array}$ \\
\hline $\begin{array}{l}\text { India (Bay of } \\
\text { Bengal) }\end{array}$ & 2003 & $1 \mathrm{~m}$ & HDPE & $\begin{array}{l}\text { CWP dropped twice; project } \\
\text { abandoned }\end{array}$ \\
\hline Makai ONR study & 2007 & $10 \mathrm{~m}$ & Steel sections & Not built yet \\
\hline $\begin{array}{l}\text { Sea Solar Power } \\
\text { studies }\end{array}$ & & & HDPE - multiple tubes & Not built yet \\
\hline
\end{tabular}



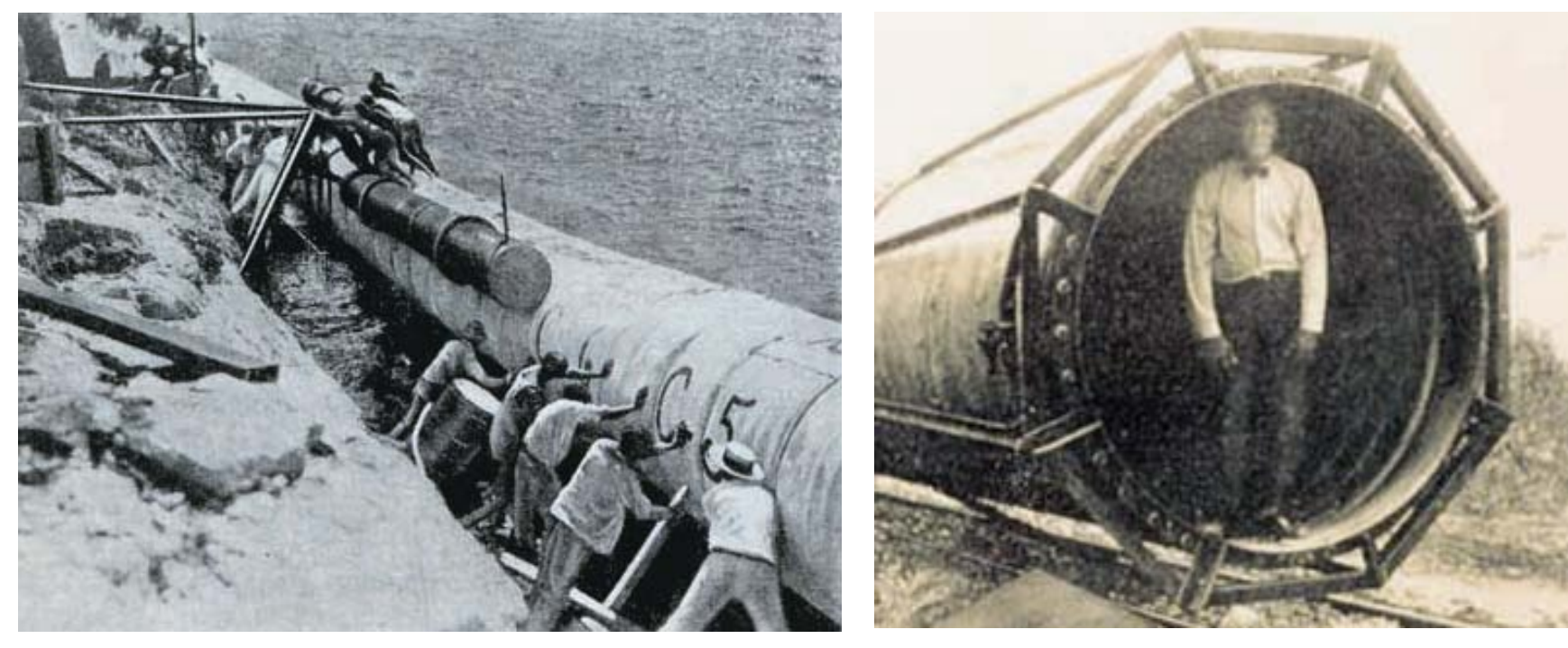

"Deploying the 2,200-yard, cold water intake tube in Cuba, far left, proved the undoing of Claude, standing, left, inside the pipe. Storms, waves, and logistical problems encountered while laying the unwieldy and vulnerable pipe, above, sank Claude's dream to harvest energy from the ocean."

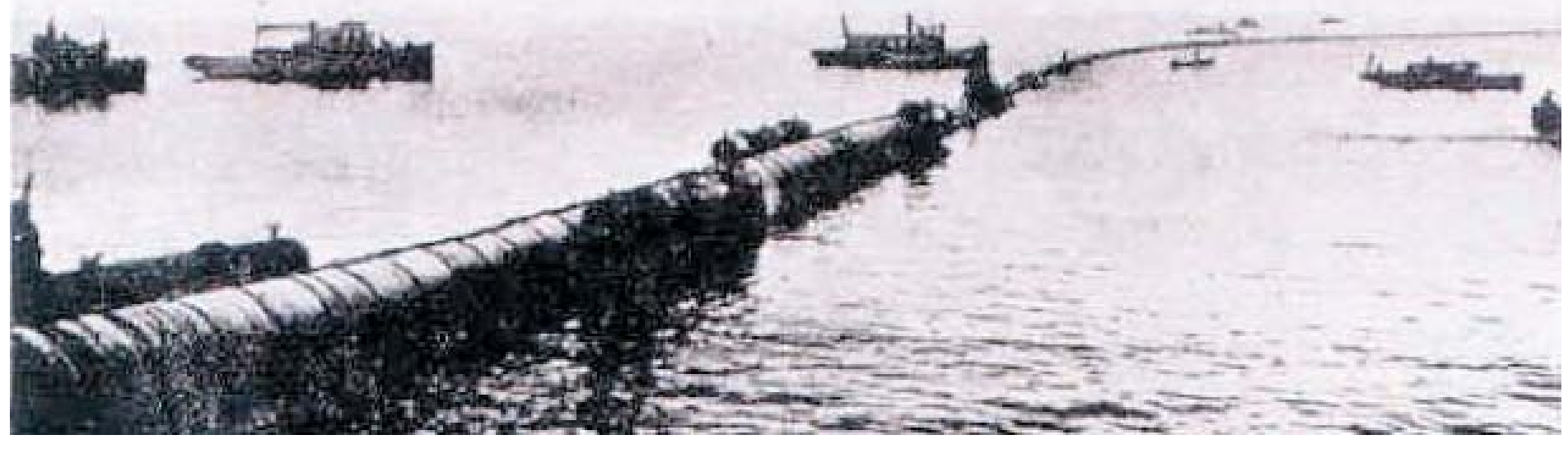




\section{The LM Advanced Composite Cold Water Pipe}

- Summary of LM Advanced Composite Cold Water Pipe Approach

- II.A - Selection of configuration, materials, and fabrication strategy

- II.B - Selection of fabrication method and major details 


\section{OIEC Pictorial summary of LM Advanced Composite Cold Water Pipe Approach}

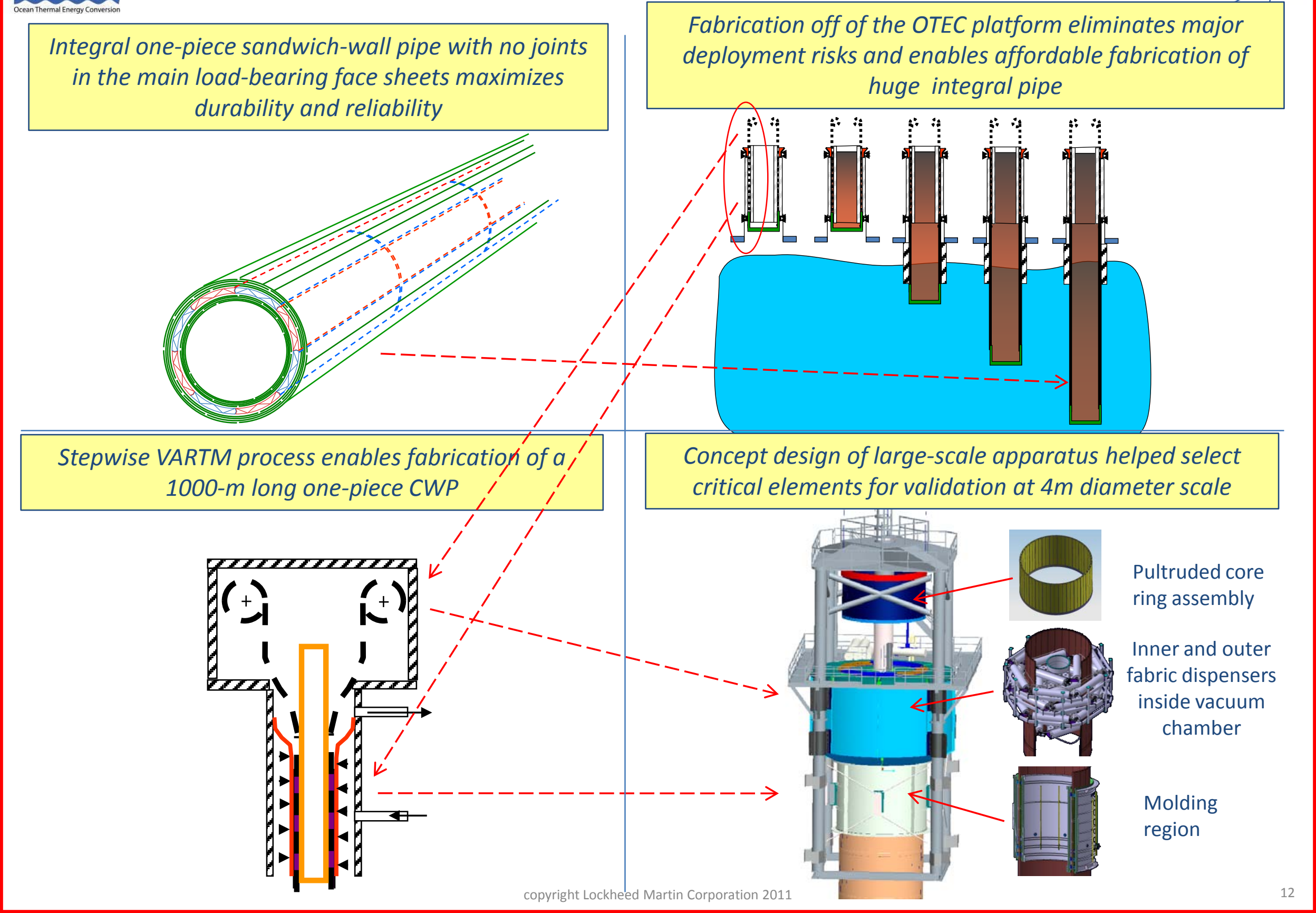




\section{A - Selection of}

\section{configuration, materials, and fabrication strategy}

(Work done prior to the DoE program, under LM MS2 IRAD funding)

- Cold Water Pipe structural requirements

- CWP architecture

- A section of LM CWP at $4 \mathrm{~m}$ diameter scale

- Fabrication strategy

- Primary basis for selecting the current CWP materials 


\section{OJEC Cold Water Pipe Structural Requirements:}

Origins, loadings, resulting features, analysis status

\begin{tabular}{|c|c|c|c|}
\hline Origin & Loading on CWP & $\begin{array}{l}\text { Leads to feature (see } \\
\text { next slide) }\end{array}$ & Analysis status \\
\hline $\begin{array}{l}\text { Wave-driven } \\
\text { platform motions }\end{array}$ & Fatigue strains & $\begin{array}{l}\text { Axial fibers; integral } \\
\text { pipe without joints }\end{array}$ & OK \\
\hline Internal suction & $\begin{array}{l}\text { Net external global } \\
\text { pressure }\end{array}$ & $\begin{array}{l}\text { Hoop fibers; sandwich } \\
\text { wall }\end{array}$ & OK \\
\hline $\begin{array}{l}\text { Grippers and } \\
\text { bushings }\end{array}$ & $\begin{array}{l}\text { Localized external } \\
\text { pressure }\end{array}$ & $\begin{array}{l}\text { Larger \# of ribs in } \\
\text { sandwich wall }\end{array}$ & OK \\
\hline $\begin{array}{l}\text { Clump weight, pipe } \\
\text { wet weight }\end{array}$ & Axial strain & Axial fibers & OK \\
\hline Water currents & Bending strain & Axial fibers & OK \\
\hline $1000 \mathrm{~m}$ length & $\begin{array}{l}1500 \text { psi water } \\
\text { pressure at depth }\end{array}$ & \multirow{2}{*}{$\begin{array}{l}\text { Vented hollow core } \\
\text { made of composite } \\
\text { laminate }\end{array}$} & \multirow{2}{*}{ OK } \\
\hline $\begin{array}{l}\text { Mildly negative wet } \\
\text { weight }\end{array}$ & & & \\
\hline $\begin{array}{c}\text { 30-year life, } \\
\text { immersed }\end{array}$ & Seawater corrosion & Vinyl ester resin & $\begin{array}{c}\text { OK by material } \\
\text { heritage }\end{array}$ \\
\hline
\end{tabular}




\section{CWP architecture}

\section{Construction: Sandwich wall with hollow vented core}

- Core: Pre-pultruded hollow "planks" assembled into core rings

- Face sheets:

Longitudinally continuous fabric strips, applied over assembled core rings

Materials

- Low-cost X-Strand ${ }^{1}$ glass fibers having superior fatigue resistance

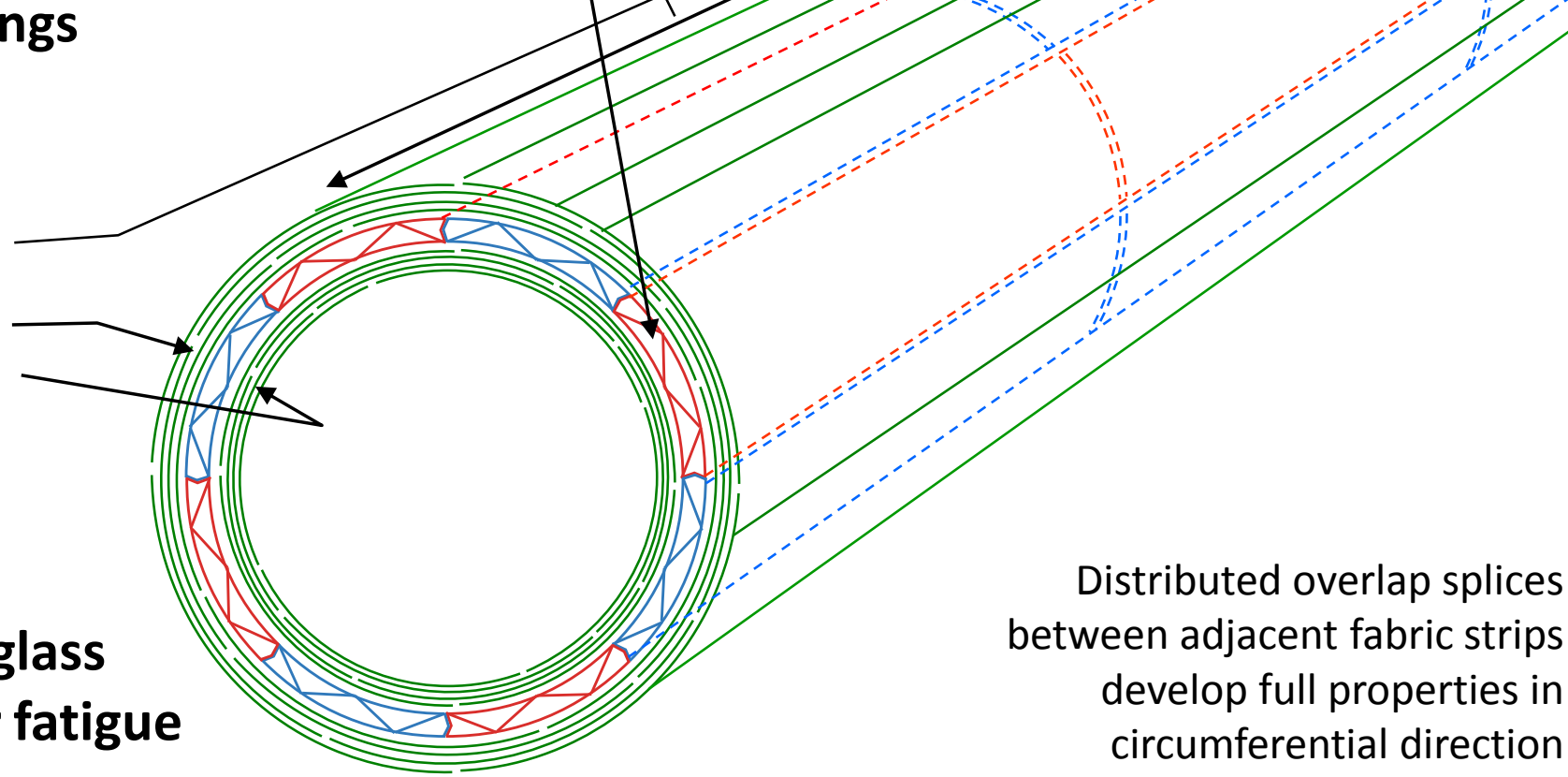

- Derakane $8084^{2}$ toughened vinyl ester resin matrix having very little water absorption

1. Product of Owens Corning Technical Fabrics

2. Product of Ashland Chemicals
Integral one-piece CWP with no joints in the main loadbearing face sheets maximizes durability and reliability 

directly from the floating platform

Overall process: Stepwise VARTM infusion molding

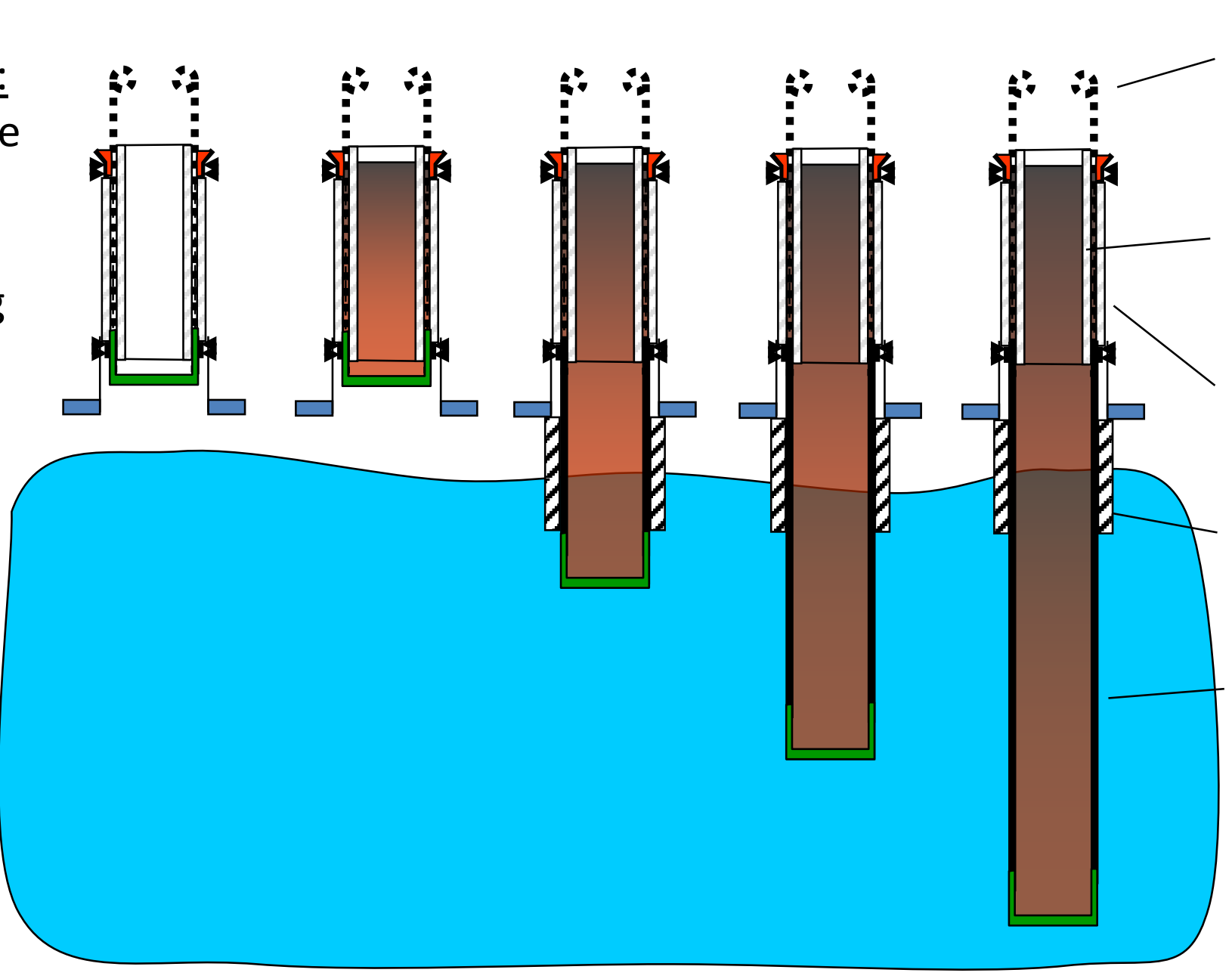

Fabric on dispensing rollers (continuous with fabric in molding region)

Hollow pultruded core rings

Molding region

Gripper/translator

Cured CWP

US Patent Application Publication \# US2009/0309271A1, 2009;

European Patent Office Application \#PCT/US2009047388, 2009

Fabrication from the platform eliminates major deployment challenges, enables integral fabrication of huge pipe, reduces transportation costs 


\section{OTEC Primary basis for selecting the current CWP materials: Recurring cost}

(materials and fabrication) of minimum-cost design of 10m CWP for 100 MW plants, in materials not eliminated by technical show-stoppers

- WIM = Wave-induced motions (from platform)

- VIV = Vortex-induced vibration

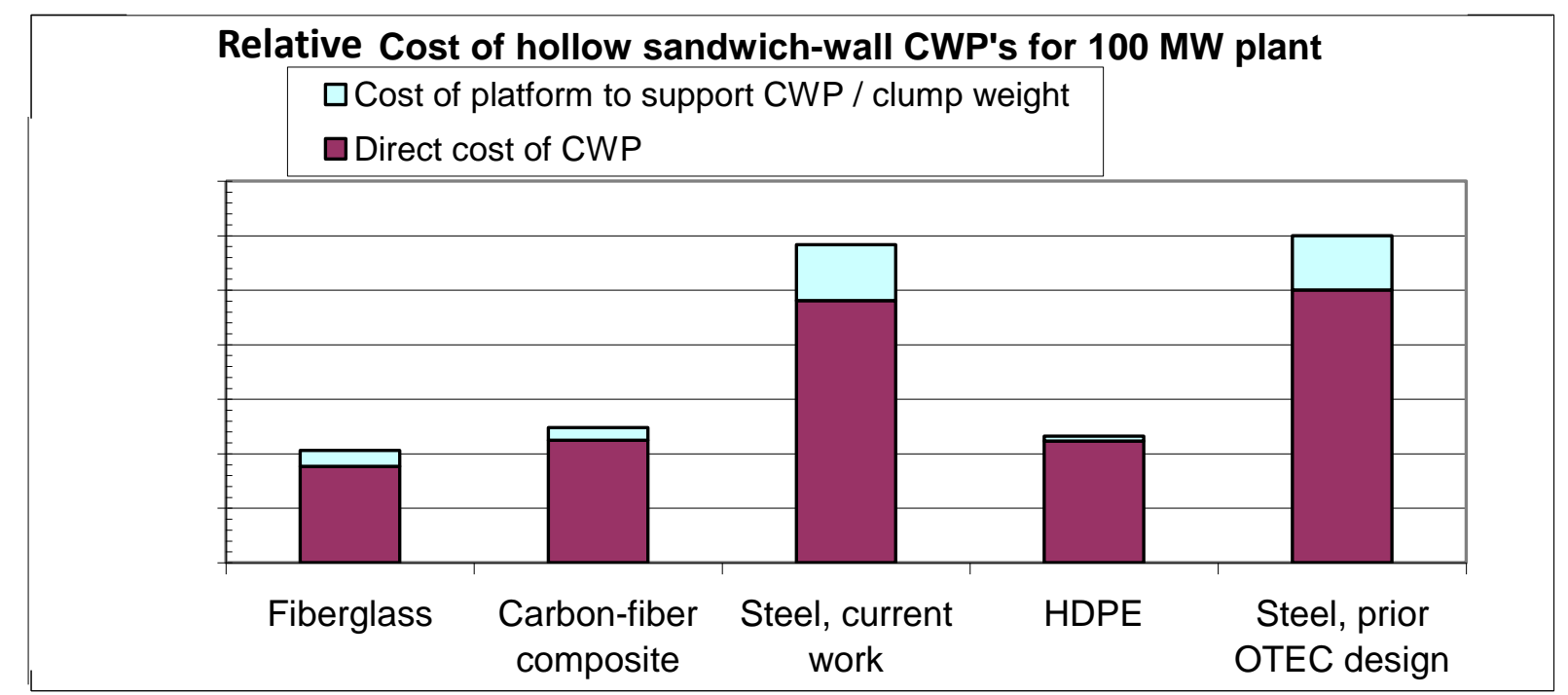

\begin{tabular}{|c|c|c|c|c|}
\hline Requirements met: & Fiberglass & $\begin{array}{c}\text { Carbon- } \\
\text { fiber } \\
\text { composite }\end{array}$ & Steel & HDPE \\
\hline External pressure & Yes & Yes & Yes & Yes \\
\hline WIM cyclic strain & Yes & Yes & No & Yes \\
\hline WIM axial buckling & Yes & Yes & Yes & Yes \\
\hline VIV cyclic strain (without strakes) & Yes & Yes & No & Yes \\
\hline Streaming and clump weight axial & Yes & Yes & Yes & Yes \\
\hline Platform rotation & Yes & Yes & Yes & Yes \\
\hline Manufacturable in low-cost configuration & Yes & Yes & Yes & No \\
\hline
\end{tabular}

Fiberglass and carbon-fiber composite are the two candidates with no show-stoppers. They have similar net costs and can be fabricated by the same methods. Fiberglass was chosen to simplify galvanic corrosion issues and to avoid near-term supply questions in the carbon fiber marketplace. 


\section{II.B - Selection of fabrication method and major details}

(Work done prior to the DoE program, under LM MS2 IRAD funding)

- Can we use an off-the-shelf composite fabrication process?

- Various possible liquid resin infusion processes as applied to vertical stepwise molding of a CWP

- VARTM - A quick summary tutorial

- VARTM of a large wind turbine blade shell

- Recent applications of large-scale VARTM technology

- CWP processing steps using stepwise VARTM

- Tooling strategy

- Elements of VARTM that are "tweaked" for our application

- Holding, lowering, and supporting the CWP during on-the-water fabrication 

process?

\begin{tabular}{|l|l|}
\hline \multicolumn{1}{|c|}{ Process } & Comments relative to usage for OTEC CWP \\
\hline $\begin{array}{l}\text { Spray-up (chopped } \\
\text { fibers) }\end{array}$ & Insufficient properties, VOC's into environment \\
\hline Wet layup (fabric) & Low fiber volume; VOC's into environment \\
\hline $\begin{array}{l}\text { Prepreg layup/ } \\
\text { autoclave cure }\end{array}$ & $\begin{array}{l}\text { Very expensive materials and labor; can only manufacture } \\
\text { finite-length segments in autoclave }\end{array}$ \\
\hline Automated tape laying & Very expensive equipment and materials \\
\hline Filament winding & $\begin{array}{l}\text { Very difficult to incorporate a sandwich core; finite-length } \\
\text { manufacturable segments require joints }\end{array}$ \\
\hline $\begin{array}{l}\text { Pultrusion (of entire } \\
\text { CWP) }\end{array}$ & $\begin{array}{l}\text { Required CWP cross-section is way too large - Pulling } \\
\text { force, fabric guidance machinery would be main issues }\end{array}$ \\
\hline Matched die molding & CWP much too large - Mold rigidity and weight issues \\
\hline Thermoplastic forming & Very expensive materials \\
\hline $\begin{array}{l}\text { Liquid resin infusion } \\
\text { (RTM, VARTM) }\end{array}$ & See next slide \\
\hline
\end{tabular}


Various possible liquid resin infusion processes as applied to vertical stepwise molding of a CWP

\begin{tabular}{|l|l|l|l|}
\hline Process & \multicolumn{1}{|c|}{ Mold } & \multicolumn{1}{|c|}{$\begin{array}{c}\text { Mold fill } \\
\text { process }\end{array}$} & \multicolumn{1}{c|}{$\begin{array}{c}\text { Can voids be } \\
\text { controlled? }\end{array}$} \\
\hline $\begin{array}{l}\text { 1. Resin Transfer } \\
\text { Molding ("ordinary } \\
\text { RTM)" }\end{array}$ & $\begin{array}{l}\text { Rigid fixed- } \\
\text { cavity mold } \\
\text { surrounds part. }\end{array}$ & $\begin{array}{l}\text { Resin flows through the } \\
\text { fabric itself. Slow fill } \\
\text { for large parts. }\end{array}$ & $\begin{array}{l}\text { Yes. Apply high resin } \\
\text { pressure during cure. } \\
\text { But requires very rigid } \\
\text { mold, prohibitive for } \\
\text { large parts }\end{array}$ \\
\hline $\begin{array}{l}\text { 2. VARTM } \\
\text { (Vacuum-Assisted } \\
\text { Resin Transfer } \\
\text { Molding) }\end{array}$ & $\begin{array}{l}\text { One-sided tool } \\
\text { with vacuum } \\
\text { bag as the } \\
\text { other side }\end{array}$ & $\begin{array}{l}\text { Resin flows through } \\
\text { high-permeability resin } \\
\text { distribution medium. } \\
\text { Rapid fill for large } \\
\text { parts. }\end{array}$ & $\begin{array}{l}\text { Yes. Pull good vacuum } \\
\text { on fabric before infusion, } \\
\text { to evacuate the air. }\end{array}$ \\
\hline
\end{tabular}

VARTM is the only composites fabrication process that meets the needs 


\section{VARTM* - A quick summary tutorial}

\section{Setup}

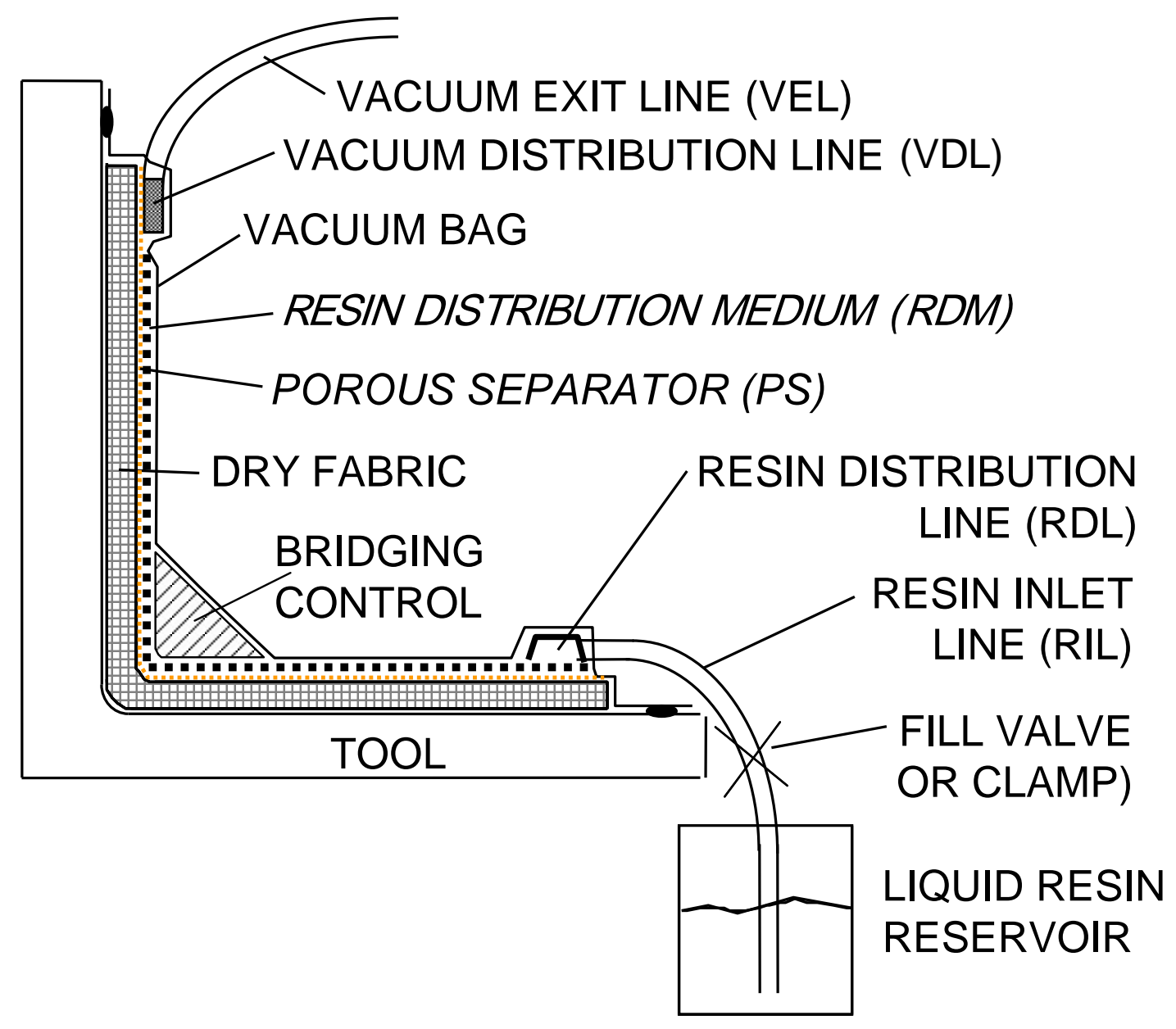

\section{Process}

- Lay up dry fabric on tool

-Apply PS, RDM, RDL, RIL, VDL, VEL, and vacuum bag

-Open fill valve

-Vacuum sucks liquid resin from a reservoir into the part

-Resin spreads quickly in the resin distribution medium (RDM, high permeability)

-Resin only has to travel throughthickness in the fabric (low permeability) - Overall wetout time for large parts is short and within the pot life of many resins

-After cure, the porous separator (PS) allows the RDM to be peeled off of the part. Or the PS can be omitted and the RDM left on the part. 


\section{OJEC}

VARTM of a large wind turbine blade shell

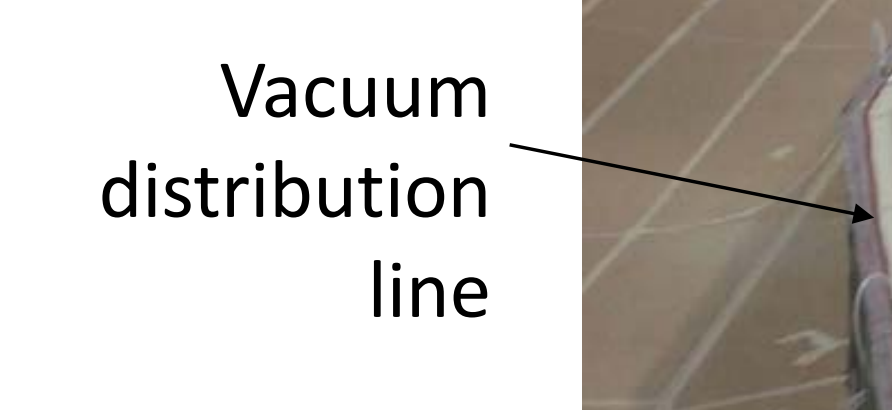

Vacuum exit line
Vacuum
trap
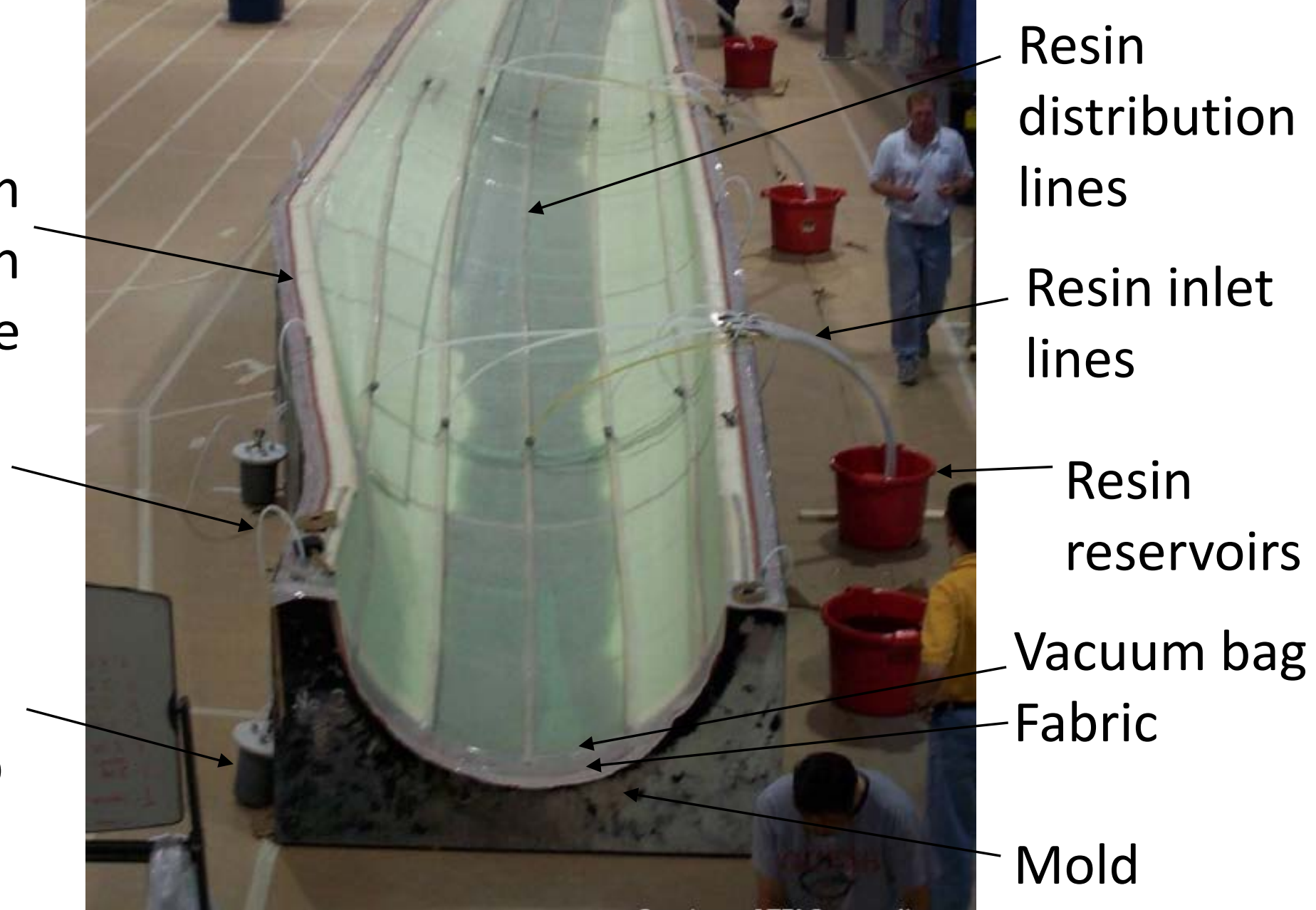
Modern wind turbine rotor blades (fiberglass shells)

size scale is similar to our CWP

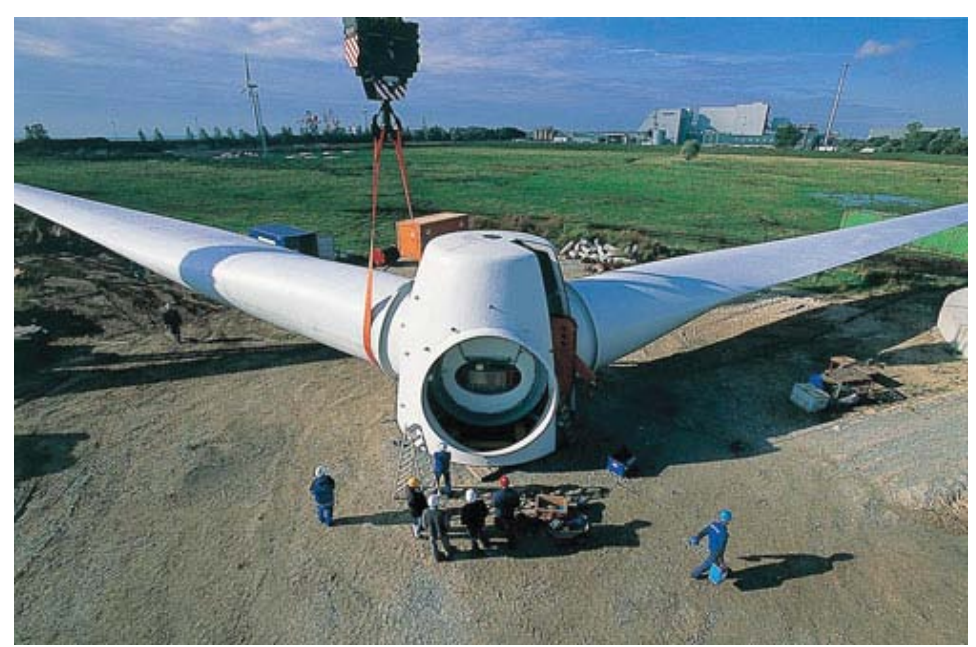

http://www.compositesworld.com/articles/wind-blade-manufacturing-part-i-mand-p-innovations-optimize-production.aspx

\section{-VARTM is currently being used} on some very large components

-There is a large business base of VARTM-experienced personnel, material suppliers, and equipment fabricators

Fiber composite highway bridge segments
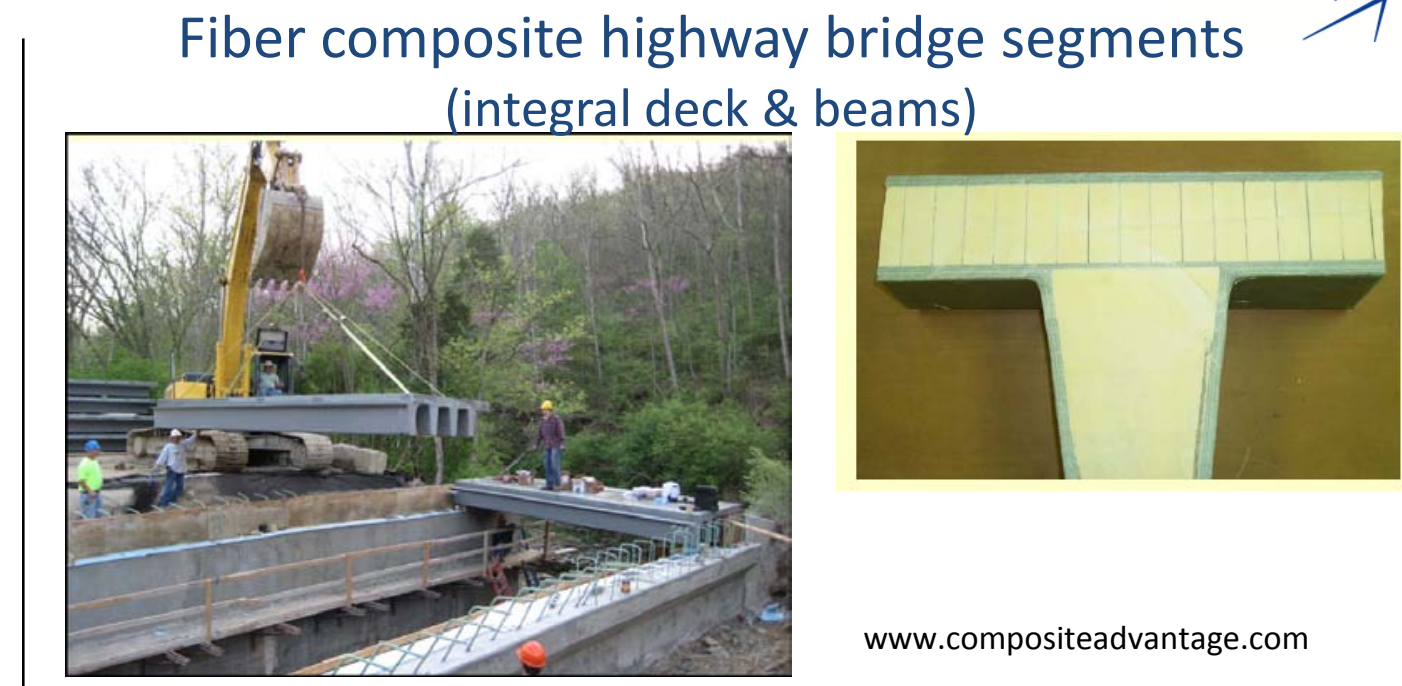

www.compositeadvantage.com 3m (10 ft.) demonstration Deep Space reflector antenna infused in one shot

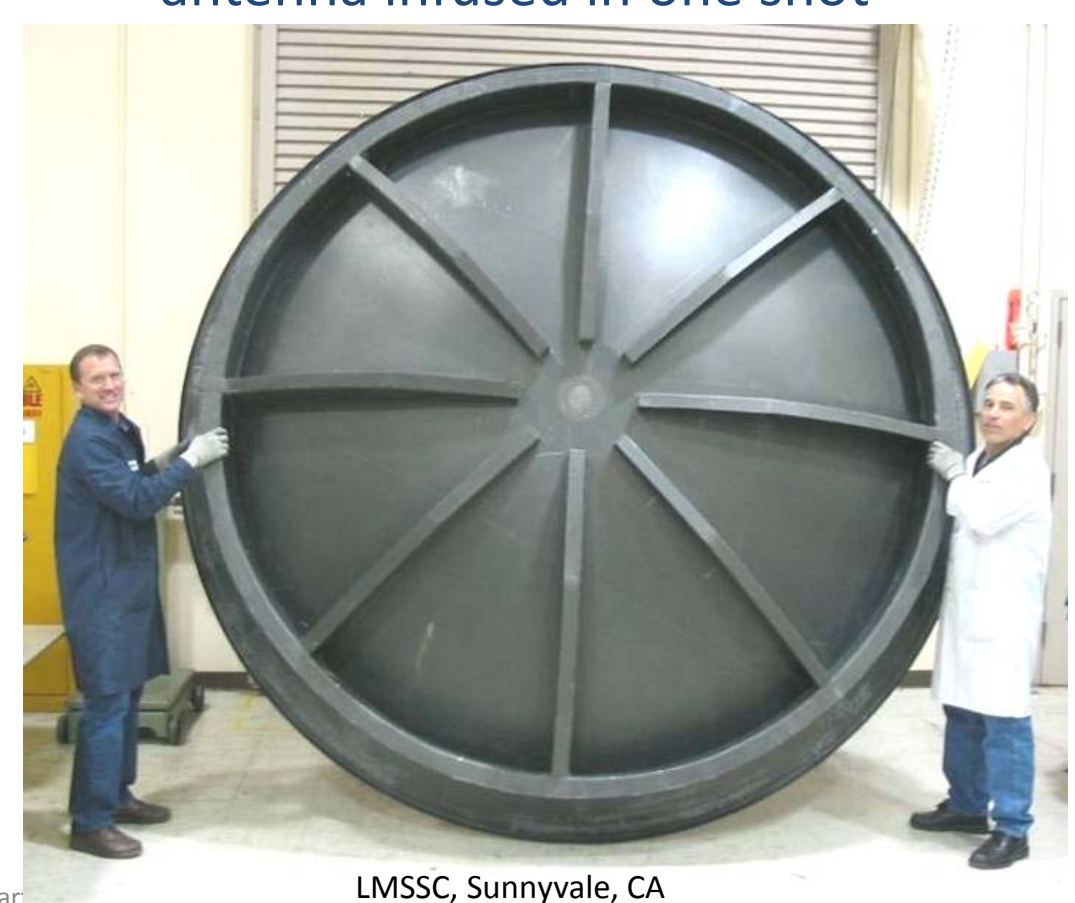


Pre-assembled ring of pultruded core planks
Fabric on rolls

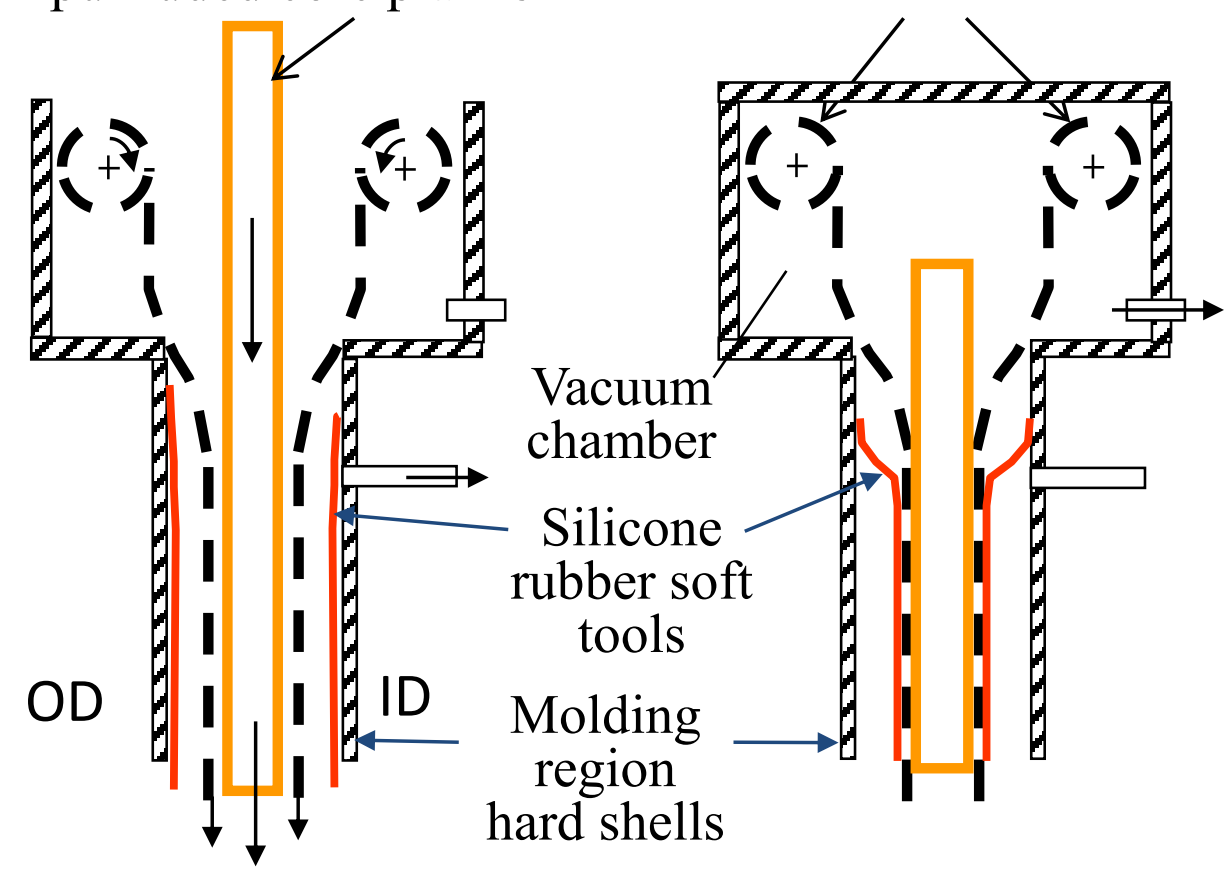

$\rightarrow$ (a) Load materials:

Maintain vacuum behind soft tools. Move cured CWP down, which pulls new fabric, RDM, and core segments into molding region (b) Evacuate air from fabric and compact it, by on workpiece and fabric rolls pulling vacuum

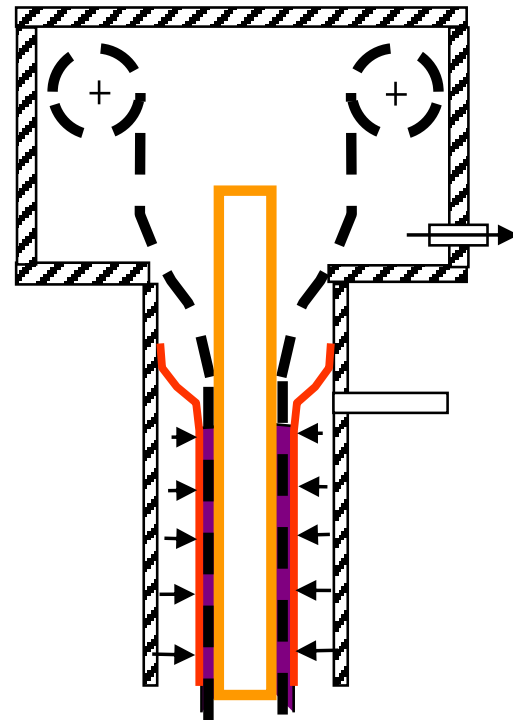

(c) Infuse resin from bottom: Use liquid behind soft tools to counteract hydrostatic pressure gradient in liquid resin column

(d) Initial cure: Ambient temperature

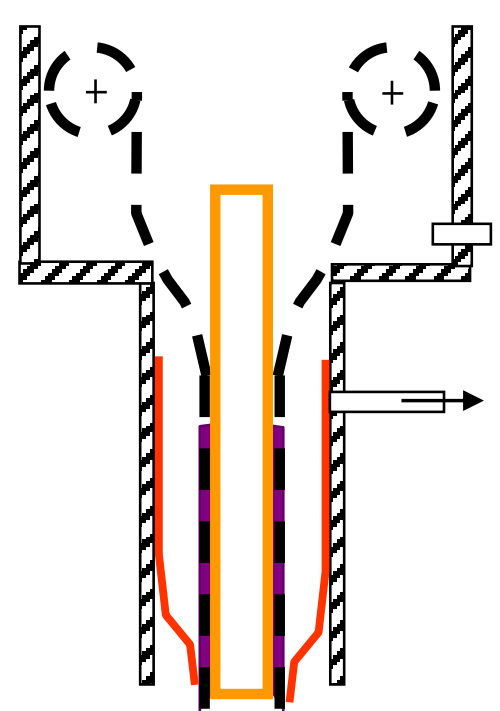

(e) Release: Apply vacuum behind soft tools

(f) Post-cure: Circulate hot air or hot water next to workpiece 
-The process is applied multiple times in a stepwise manner to a single workpiece

-The shape-defining element (assembled pultruded core) becomes part of the product

-The vacuum bag (soft tools) can be pulled away from the workpiece over the entire inner and outer surfaces

-The resin distribution lines are re-usable

-The resin distribution medium is left on the product and doubles as a "gel-coat" 
OTEC Holding, lowering, and supporting the CWP during on-the-water fabrication

Work done by Makai Ocean Engg. under LM program N62583-09-C-0083 sponsored by the US Navy Facilities Command
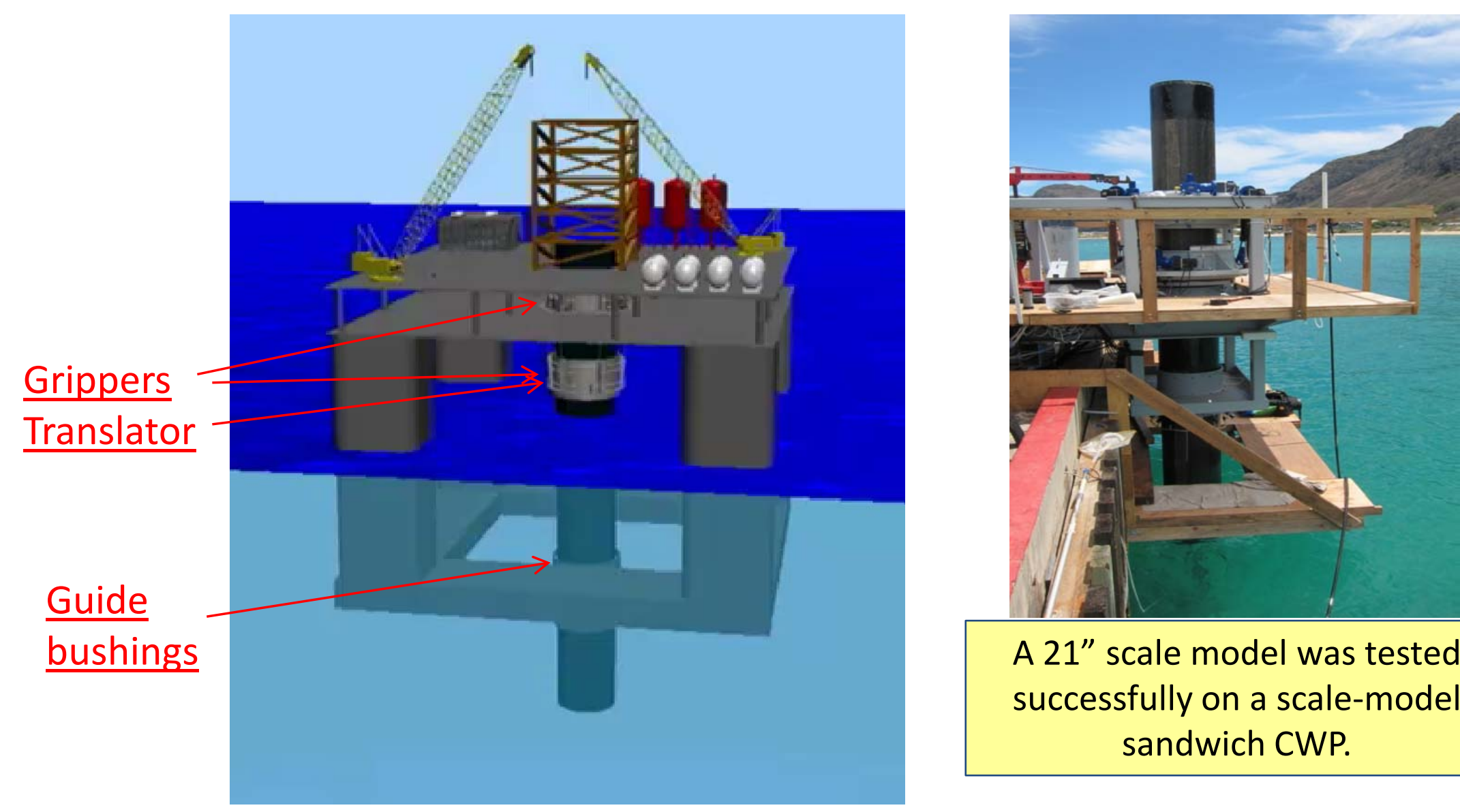

A 21 " scale model was tested successfully on a scale-model sandwich CWP.

Gripper and bushings have been designed by Makai Ocean Engineering to manipulate and support the CWP during fabrication and subsequent service. 
III. Analyses to date of CWP

\section{structural behavior}

(Work done outside of the DoE program, under LM MS2 IRAD or US Navy funding)

- External pressure buckling

- Localized buckling from gripper and guide bushing pressures

- Fatigue resistance after seawater conditioning to saturation

- Coupled hydrodynamic analysis of fatigue from platform motions 


\section{OJEC $\quad$ External pressure buckling}

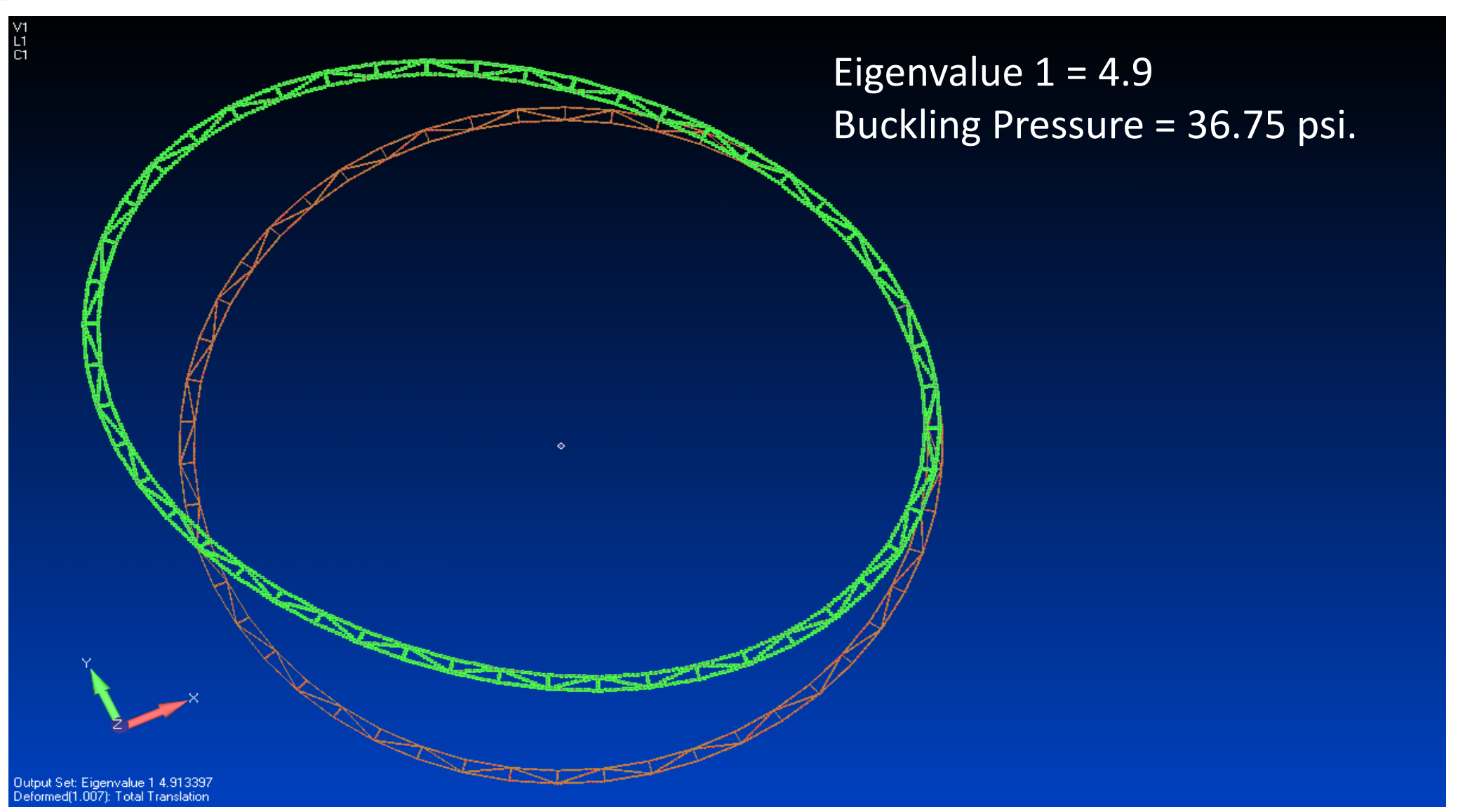

- Triangular core cell design works well for external pressure loadings

- $\quad$ FEA predicted buckling pressure of $\mathbf{3 6 . 7 5}$ psi exceeds operating pressure of 7.5 psi by a large Margin-of-Safety 


\section{OTEC Localized buckling from gripper and guide bushing pressures}

Work done at LM MS2 under LM program N62583-09-C-0083 sponsored by the US Navy Facilities Command

Pressure applied over 128" axid length
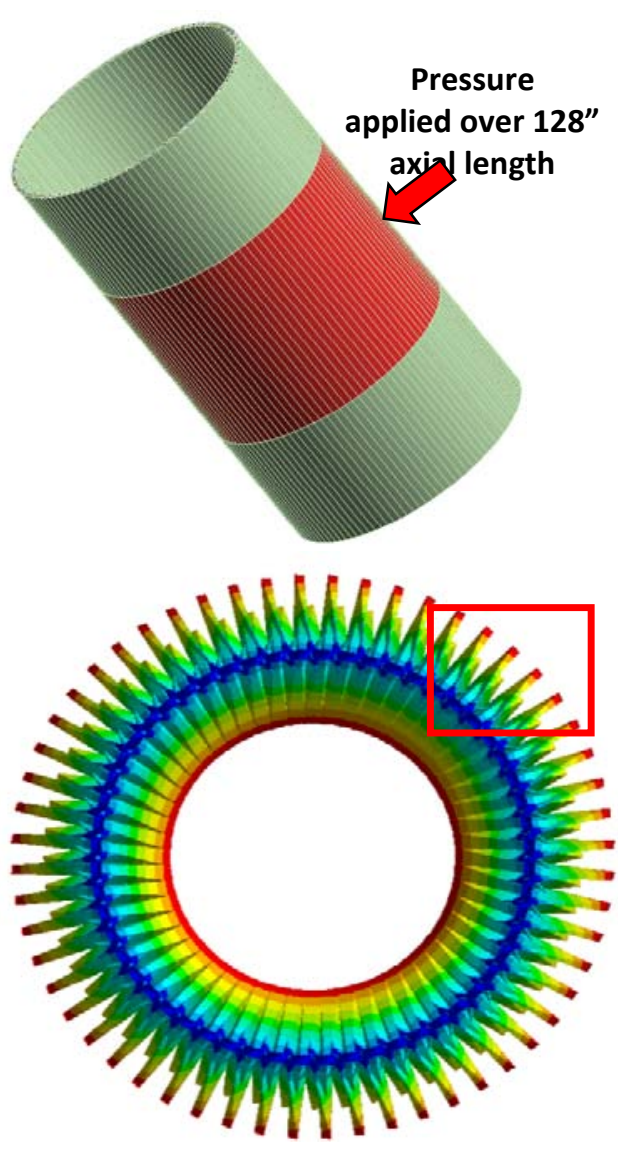

Mode 5: 163.8 psi

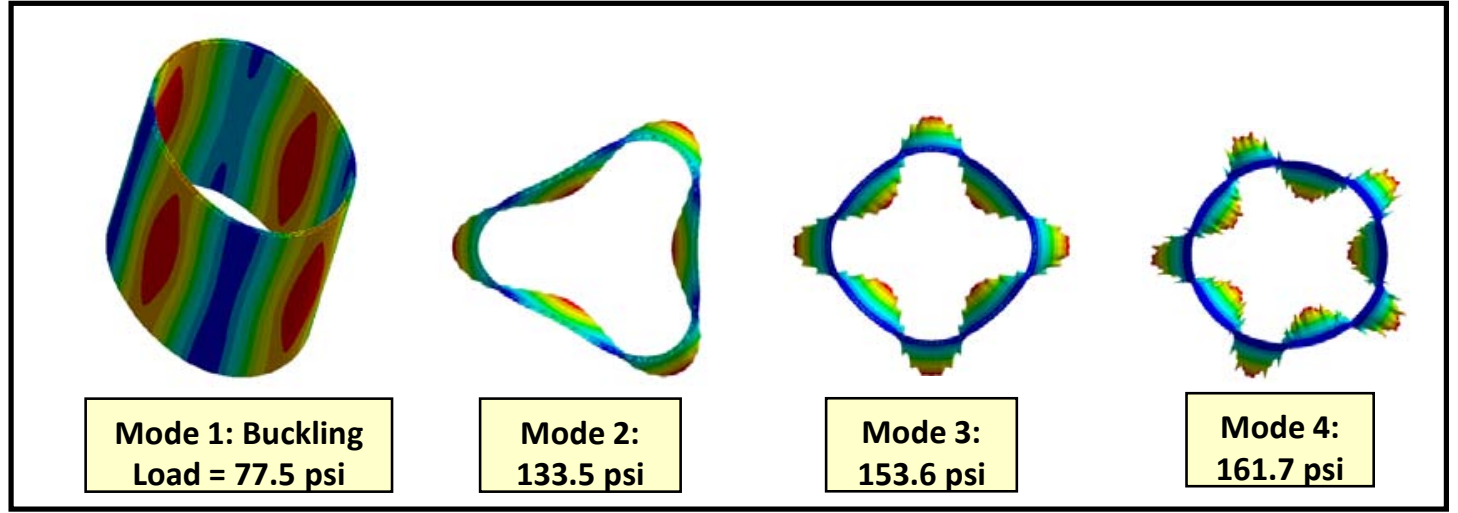

In the bushing and gripper regions, the lower modes will be prevented by the rigid circular rings of the guides and grippers

$4 m$ CWP has local buckling pressure of 164 psi, adequate for the localized forces imposed by bushings operating at 50 to 75 psi local pressure. 


\section{Fatigue resistance after seawater conditioning to saturation: Selected CWP material shows only 6\% knockdown relative to dry material}

$\mathrm{X}$-Strand/vinyl ester hot press cured laminate tension-tension fatigue resistance at ambient temperature - Dry, and wet after seawater conditioning to saturation

W.Va.U. tests: X-Strand 75\% 0's filament-wound, hot press cured laminates in air (no conditioning)

- Best fit through WVaU test data on unconditioned 75\% 0's laminate tested dry

$\square$ W.Va.U tests: X-Strand 75\% 0's filament-wound, hot press cured laminate in seawater -- after RT/1700 psi seawater conditioning to saturation

- Adjust WVaU pre-exponential constant to provide best fit through mean WVaU data on seawater conditioned $75 \%$ 0's laminate tested in seawater

- -Design minimum for 75\% 0's material after seawater conditioning (10\% below average strength per scatter in other data sets)

$\bigcirc$-WVaU 75\% 0's dry tensile test data (Strain amplitude calculated from UTS/Modulus)

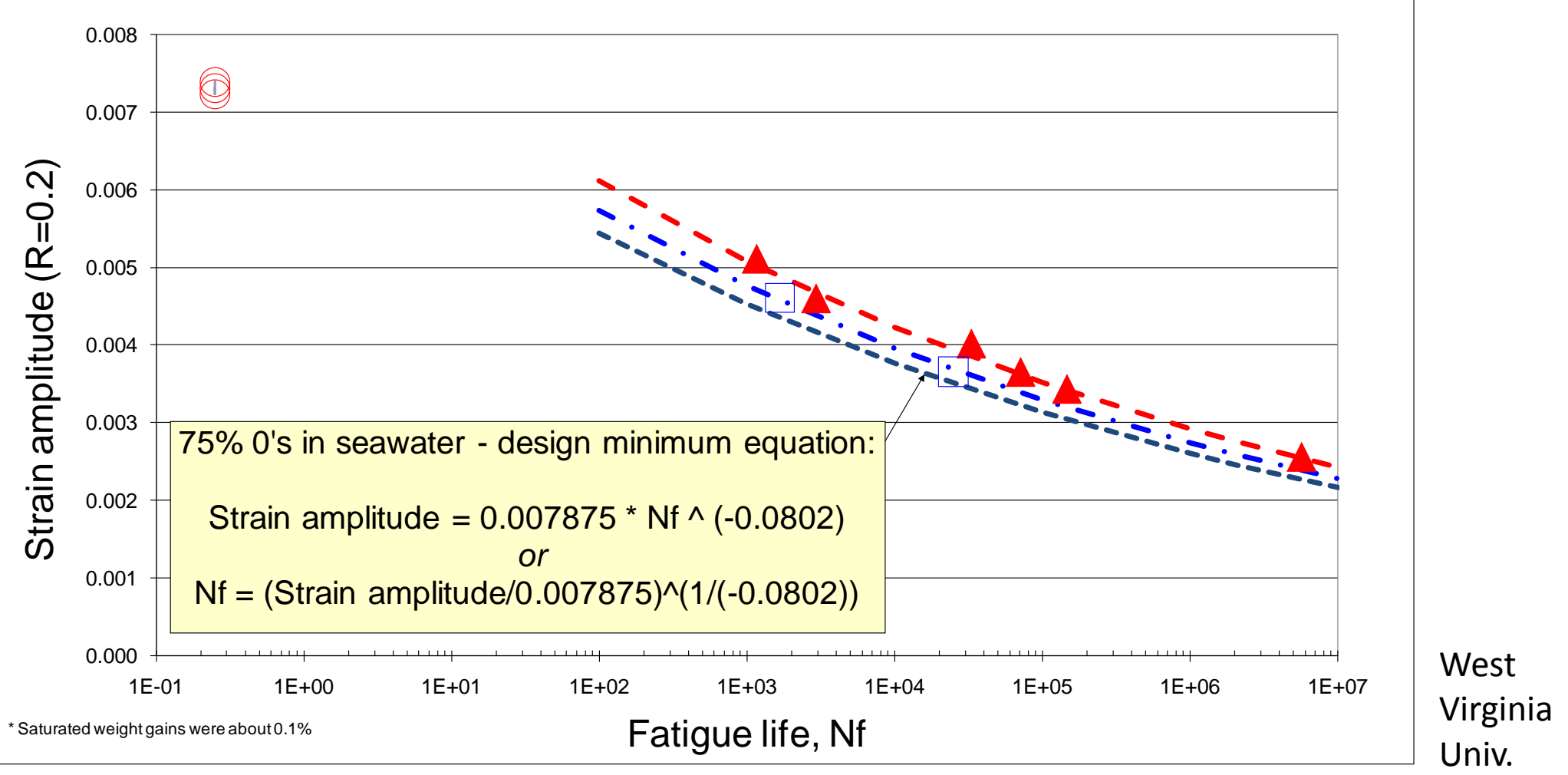

Seawater fatigue testing provides known material behavior for current work. 


\section{Coupled hydrodynamic analysis of} fatigue from platform motions

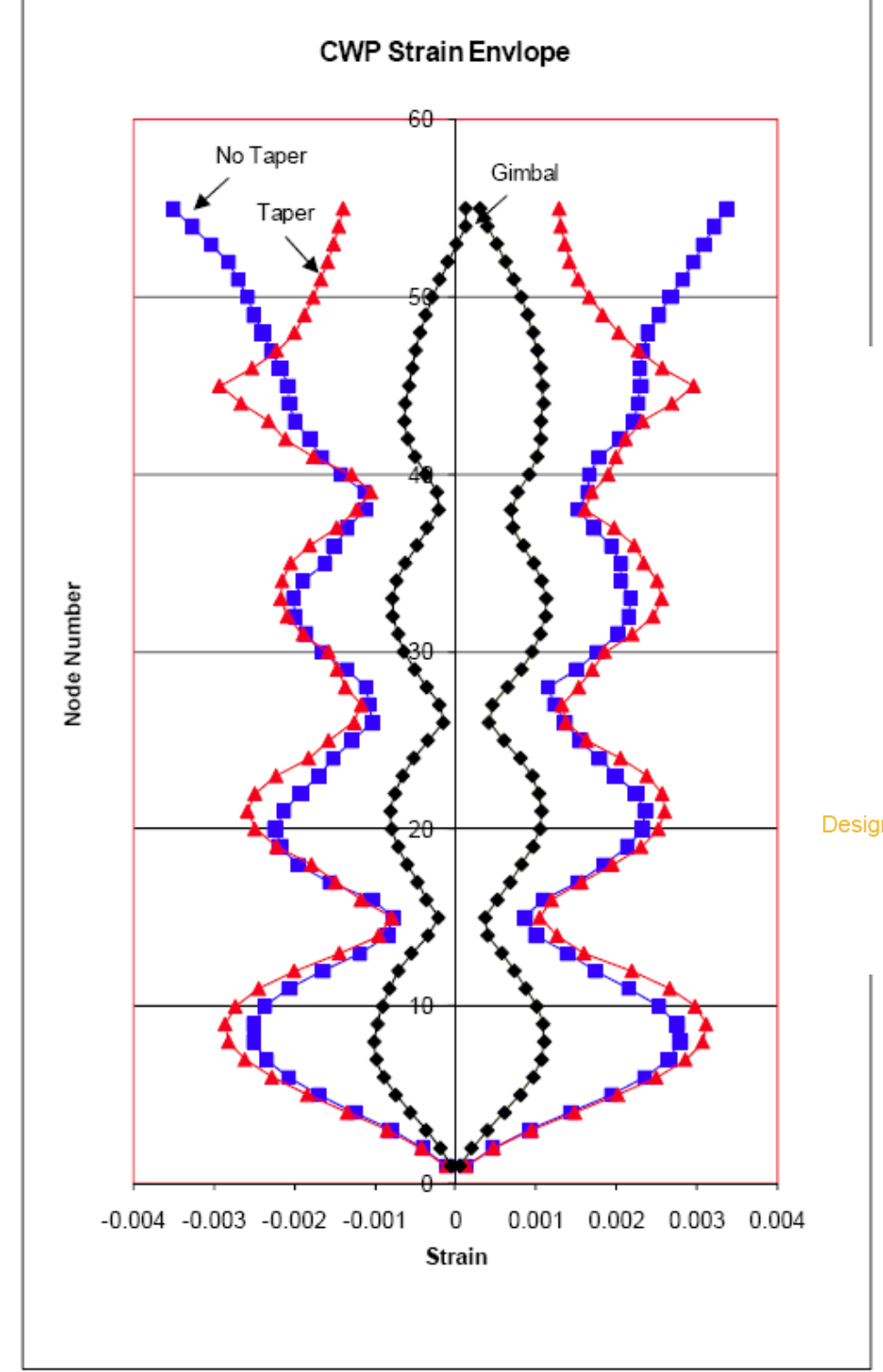

Figure 57. Strain Envelope for $10 \mathrm{~m}$ Tapered Pipe
Work done by John Halkyard and Associates and Houston Offshore Engineering under LM program N62583-09-C-0083 sponsored by the US Navy Facilities Command. Work utilized design minimum curve from the previous figure.

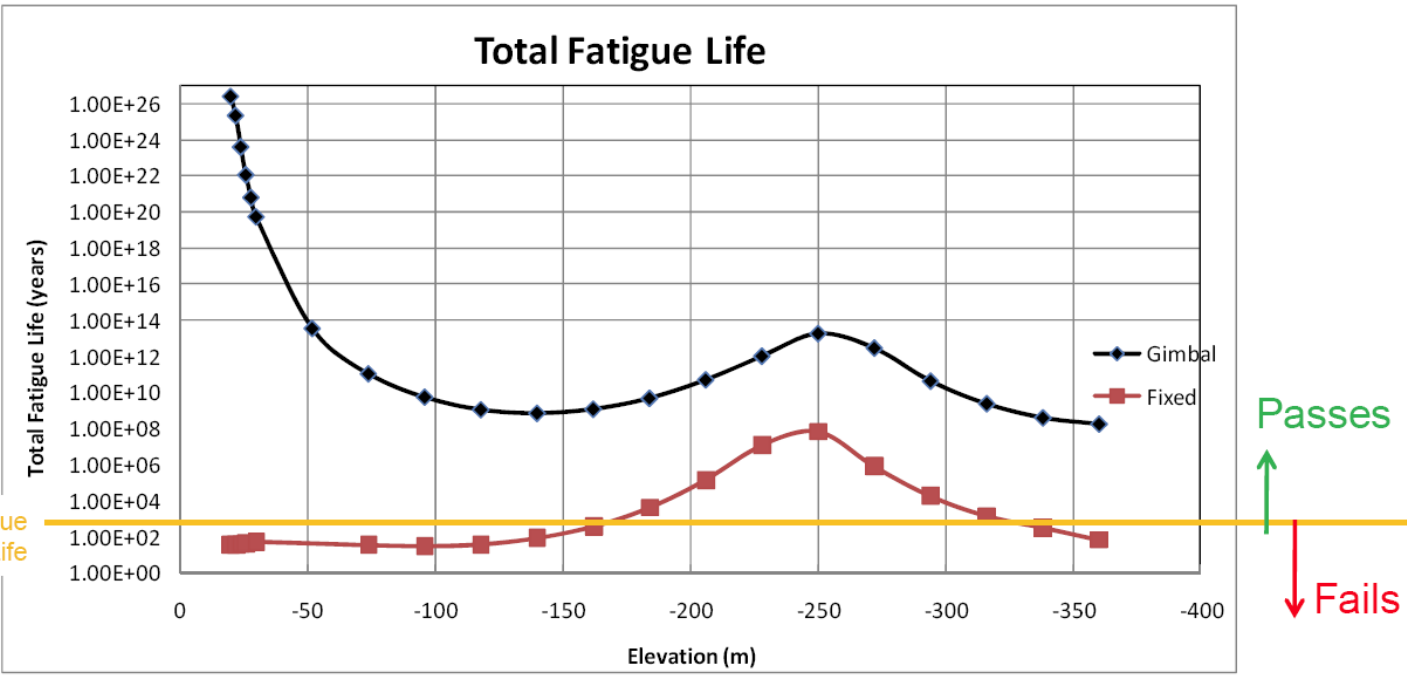

-Without a gimbal, the current 10m CWP design has a slightly negative Margin-of-Safety

-Tapering does not help much

-A gimbal brings the MOS to a strongly positive level 


\section{OJEC}

IV. Proof-of-Principles Validation of the CWP fabrication process

(Work done prior to the DoE program, under LM MS2 IRAD funding)

- Proof-of-Principles apparatus

- First Proof-of-Principles workpiece

- CWP fabrication process elements validated by the Proof-of-Principles work at 19 " scale 
The CWP fabrication process was first validated at laboratory scale (19" dia.) with a Proof-of-Principles apparatus

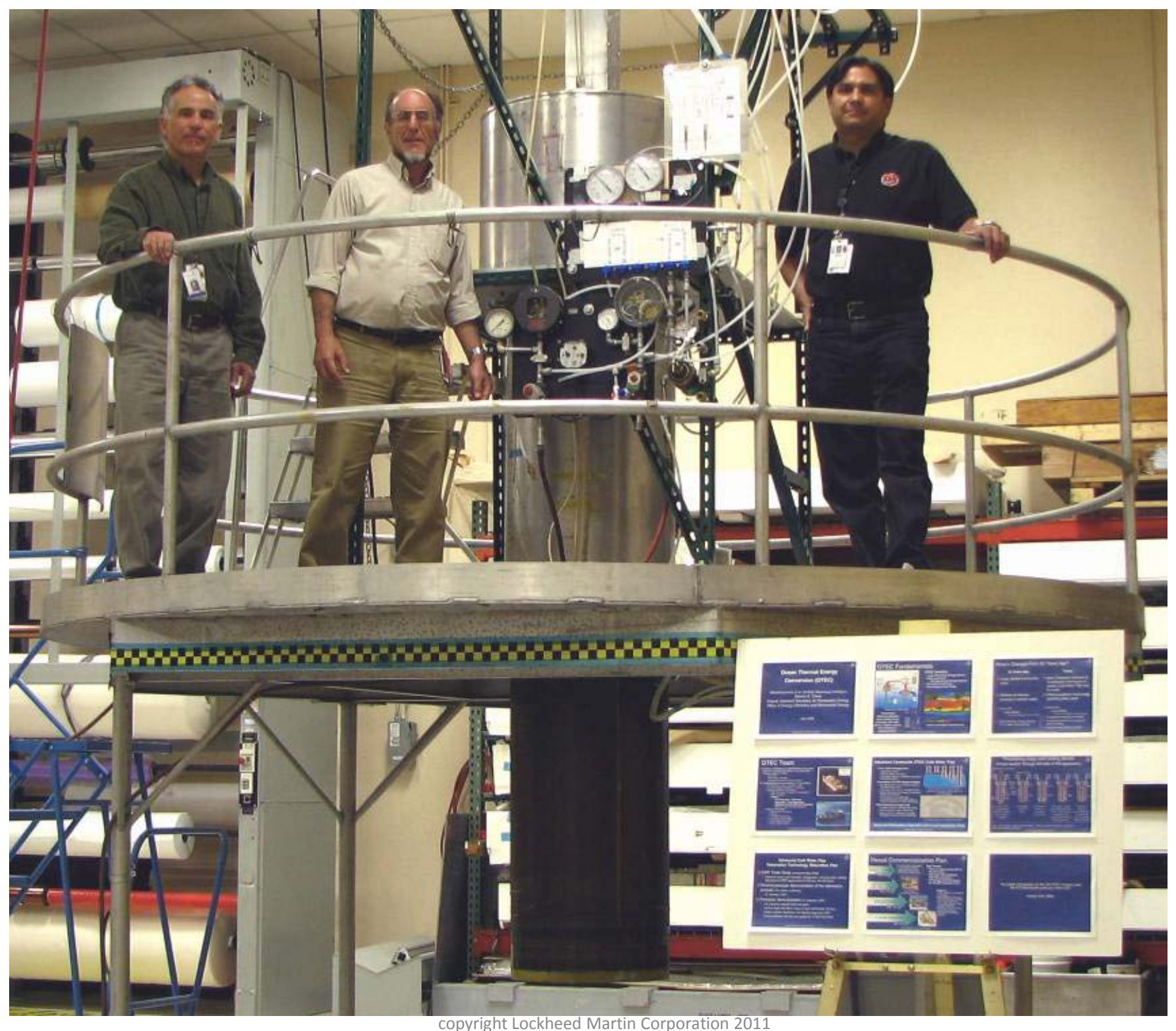




\section{OTEC First Proof-of-Principles workpiece infused by VARTM}

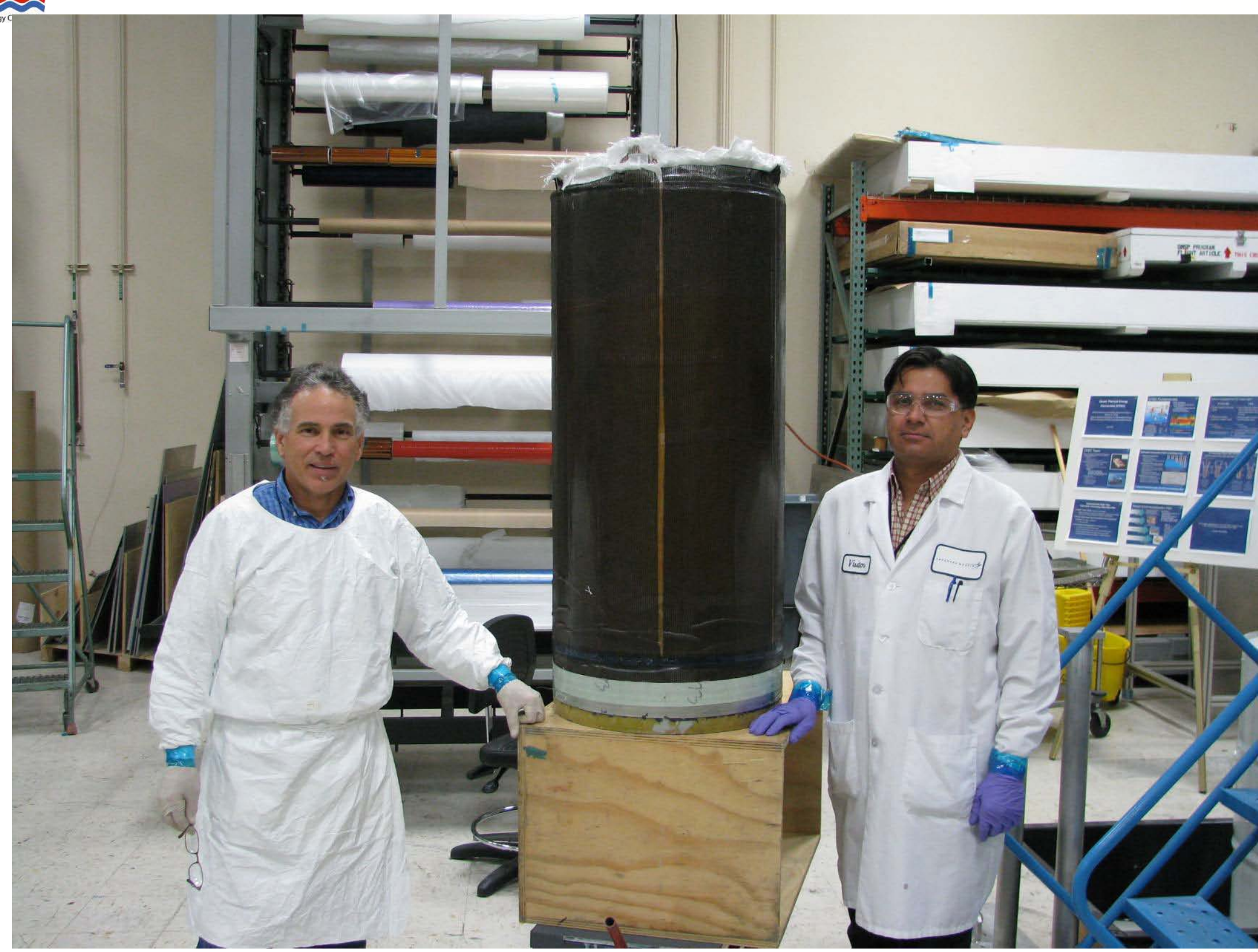


The PoP work validated behavior of the CWP fabrication process in the following areas, and provided the confidence to continue with the same approaches into the subsequent DoE-sponsored work

- Mold action

- Fabric behavior

- Sealing ends of current workpiece / pulling vacuum

-Infusion behavior

- Resin behavior

- Co-bonding behavior 


\section{Proof-of-Principles work validated the key elements at 19" scale (p. 1 of 2)}

\begin{tabular}{|c|c|c|c|}
\hline Element & Tested? & $\begin{array}{l}\text { Works as } \\
\text { expected? }\end{array}$ & $\begin{array}{l}\text { Use same approach in } \\
\text { Prototype and beyond? }\end{array}$ \\
\hline \multicolumn{4}{|l|}{ Mold action } \\
\hline Expanding/contracting soft tools & Yes & Yes & Yes \\
\hline Good compaction of FS & Yes & Yes & Yes \\
\hline Good release of soft tools from part & Yes & Yes & Yes \\
\hline \multicolumn{4}{|l|}{ Fabric behavior } \\
\hline Accurate mechanized dry fabric placement & Yes & Yes & Yes \\
\hline No unacceptable wrinkling in outer FS & Yes & Yes & $\begin{array}{c}\text { Yes - with pre-stitched unit } \\
\text { fabric }\end{array}$ \\
\hline \multicolumn{4}{|l|}{ Sealing / pulling vacuum } \\
\hline Lower inflatable seals & Yes & Yes & Yes \\
\hline Upper vacuum chamber over fabric rolls & Yes & Yes & Yes \\
\hline \multicolumn{4}{|l|}{ Infusion behavior } \\
\hline Good resin spreading (using VARTM) & Yes & Yes* & Yes \\
\hline Full wetout through-thickness & Yes & Yes & Yes \\
\hline Good wet-out at knit-line between steps & Yes & Yes & Yes \\
\hline
\end{tabular}

*After changing to a $2^{\text {nd }}$ generation resin spreading method (VARTM) based on results with the $1^{\text {st }}$ generation method 
Proof-of-Principles work validated the key elements at 19" scale (p. 2 of 2)

\begin{tabular}{|c|c|c|c|}
\hline Element & Tested? & $\begin{array}{l}\text { Works as } \\
\text { expected? }\end{array}$ & $\begin{array}{l}\text { Use same approach in } \\
\text { Prototype and beyond? }\end{array}$ \\
\hline \multicolumn{4}{|l|}{ Resin behavior } \\
\hline $\begin{array}{l}\text { Resin mixing and handling without } \\
\text { exotherm }\end{array}$ & Yes & Yes & $\begin{array}{l}\text { Yes - Using metering/ } \\
\text { mixing machine }\end{array}$ \\
\hline Rapid ambient temperature cure & Yes & Yes & Yes \\
\hline \multicolumn{4}{|l|}{ Good final properties } \\
\hline Low void content & Yes & Yes & Yes \\
\hline Uniform fiber volume & In progress & & \\
\hline Accurate fiber volume control & In progress & & \\
\hline \multicolumn{4}{|l|}{ Co-bonding behavior } \\
\hline $\begin{array}{l}\text { Good bond between infused face } \\
\text { sheets and prefabricated core }\end{array}$ & Yes & Yes & Yes \\
\hline \multicolumn{4}{|l|}{ Good dimensional control of part } \\
\hline Circularity when using core "planks" & In progress & & Yes \\
\hline Uniformity of outer diameter & In progress & & Yes \\
\hline Shear key works OK & Yes & $\begin{array}{l}\text { Did not } \\
\text { engage fully }\end{array}$ & $\begin{array}{l}\text { Yes, or use staggered } \\
\text { planks instead }\end{array}$ \\
\hline
\end{tabular}




\section{The PoP work identified the major improvements to be made in the scaled-up apparatus}

\begin{tabular}{|c|c|c|}
\hline Element & Inadequacy with PoP & Improvement in Prototype \\
\hline Soft tools & $\begin{array}{l}\text { Suspected pinhole may have led to } \\
\text { water leakage onto part and } \\
\text { incomplete cure of resin in run 3B }\end{array}$ & $\begin{array}{l}\text { Use double layer of silicone rubber with } \\
\text { monitoring between them for any water } \\
\text { leakage }\end{array}$ \\
\hline Shear key & $\begin{array}{l}\text { Suspected lack of full engagement of } \\
\text { shear key on Run 3B }\end{array}$ & $\begin{array}{l}\text { More precise tolerancing and in-process } \\
\text { checking to assure full engagement }\end{array}$ \\
\hline $\begin{array}{l}\text { Coverage with } \\
\text { RDM }\end{array}$ & $\begin{array}{l}\text { Excessive gaps between RDM strips } \\
\text { caused incomplete wet-out }\end{array}$ & Use overlap splices between RDM strips \\
\hline $\begin{array}{l}\text { Monitoring resin } \\
\text { height during } \\
\text { infusion }\end{array}$ & $\begin{array}{l}\text { External sight tube did not work } \\
\text { reliably due to air bubbles getting into } \\
\text { it from resin inlet, and shooting to top }\end{array}$ & $\begin{array}{l}\text { Use pre-calculated resin quantity for fill; } \\
\text { possibly also use embedded fiber optic as } \\
\text { cross-check }\end{array}$ \\
\hline $\begin{array}{l}\text { Resin distribution } \\
\text { line units }\end{array}$ & $\begin{array}{l}\text { Non-reusable design requires } \\
\text { excessive fabrication labor }\end{array}$ & $\begin{array}{l}\text { Develop solvent-flushable unit that can be left } \\
\text { in place }\end{array}$ \\
\hline $\begin{array}{l}\text { Fabric } \\
\text { configuration }\end{array}$ & $\begin{array}{l}\text { Some circumferential wrinkling } \\
\text { observed; one cause may be double } \\
\text { layer of fabric wound on supply rolls }\end{array}$ & $\begin{array}{l}\text { Have fabric supplier pre-stitch fabrics together } \\
\text { into a single unit (standard industry } \\
\text { technique). Track down any other causes. }\end{array}$ \\
\hline $\begin{array}{l}\text { Lower vacuum } \\
\text { seal }\end{array}$ & $\begin{array}{c}\text { Using Tygon tubing limited radial } \\
\text { travel }\end{array}$ & $\begin{array}{l}\text { Use purchased SealMaster seals designed } \\
\text { with ample radial travel }\end{array}$ \\
\hline $\begin{array}{l}\text { Access to inner } \\
\text { resin distribution } \\
\text { line unit }\end{array}$ & $\begin{array}{l}\text { Lack of center access hole in } \\
\text { cylindrical vacuum chamber makes } \\
\text { access to inner RDL awkward }\end{array}$ & $\begin{array}{l}\text { Incorporate large center access hole by } \\
\text { changing to toroidal vacuum chamber }\end{array}$ \\
\hline Vacuum leaks & $\begin{array}{l}\text { Many joints between components } \\
\text { were sealed with sealant tape }\end{array}$ & $\begin{array}{l}\text { Incorporate standard vacuum sealing methods } \\
\text { such as O-rings between components }\end{array}$ \\
\hline
\end{tabular}




\section{OIE}

\section{Design configuration of the full CWP fabrication apparatus}

- Design configuration of the full CWP fabrication apparatus

- The apparatus will go inside a weather enclosure on the floating OTEC platform 


\section{Design configuration of the full CWP fabrication} apparatus implements the process at large scale

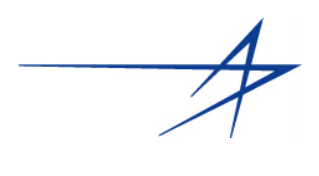

Core assembly region

Vacuum chamber with fabric dispensers inside

Molding region

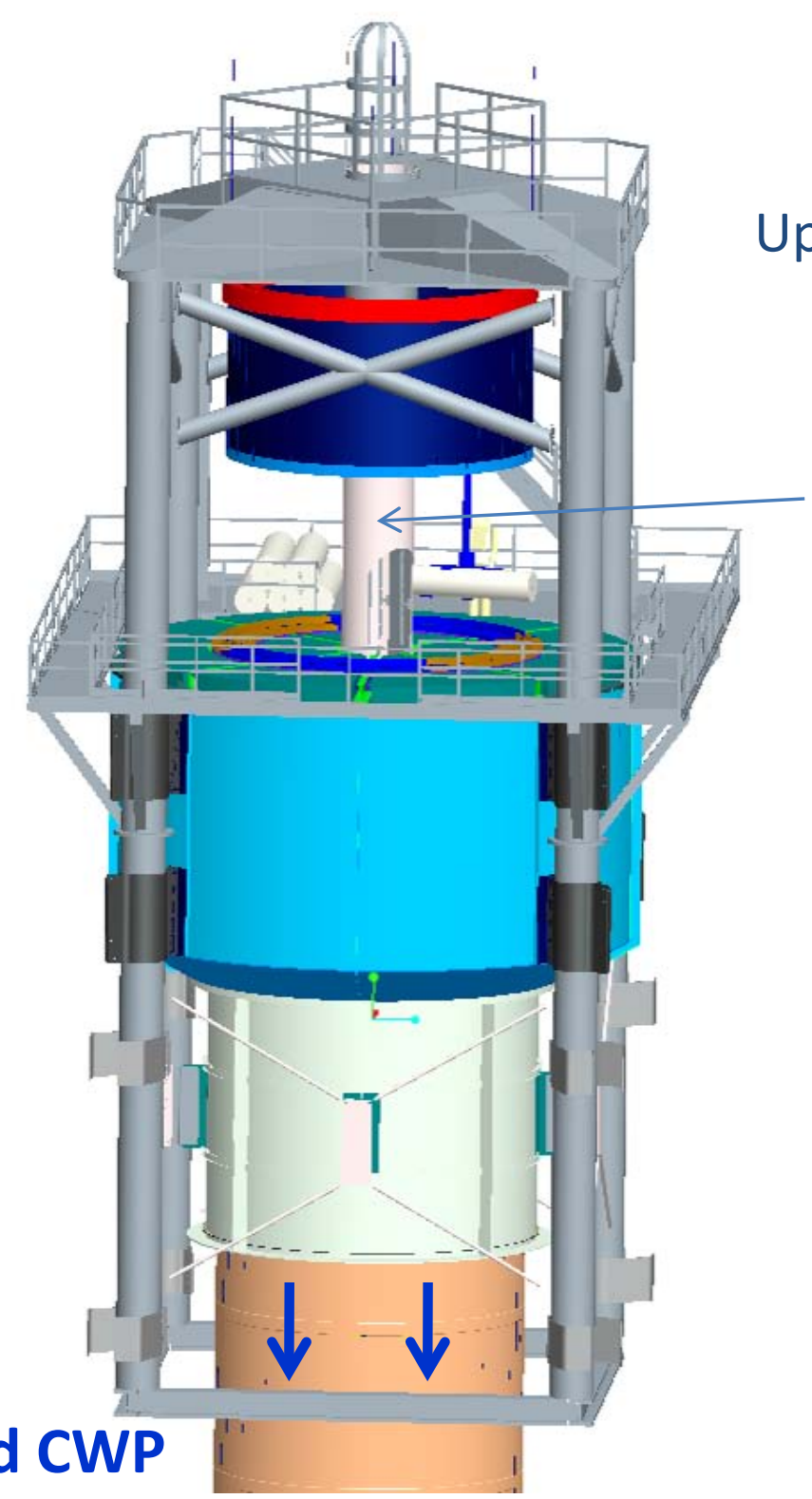

Upper support structure

Central tube supports all lower inner portions of apparatus

\section{Cured CWP}

Chad Nevills, Pat Quigley 


\section{OTEC To fabricate the CWP for the Pilot Plant and commercial plants, the}

apparatus will go inside a weather enclosure on the floating OTEC platform

Work done by Sound and Sea Technologies under an LM program sponsored by the US

Navy Facilities Command

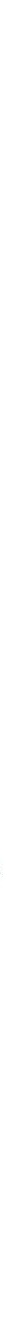


VI. Validation of the CWP fabrication

\section{process at $4 \mathrm{~m}$ diameter scale}

Work sponsored by the US Department of Energy and performed under DoE / LM MS2 Cooperative Agreement \# DE-FC36-08G018172 


\section{Validation of the CWP}

fabrication process at $4 \mathrm{~m}$

\section{diameter scale}

- Major apparatus and process elements selected for validation at 4m CWP scale under the DoE AWPP

- VI.A - Validation 1 - Core plank production and assembly into core rings

- VI.B - Validation 2 - Fabric architecture, production, overlap splice performance, and fabric dispensing process

- VI.C - Validation 3 - Stepwise infusion molding process 
Major apparatus and process elements selected for validation at 4m CWP scale under the DoE AWPP

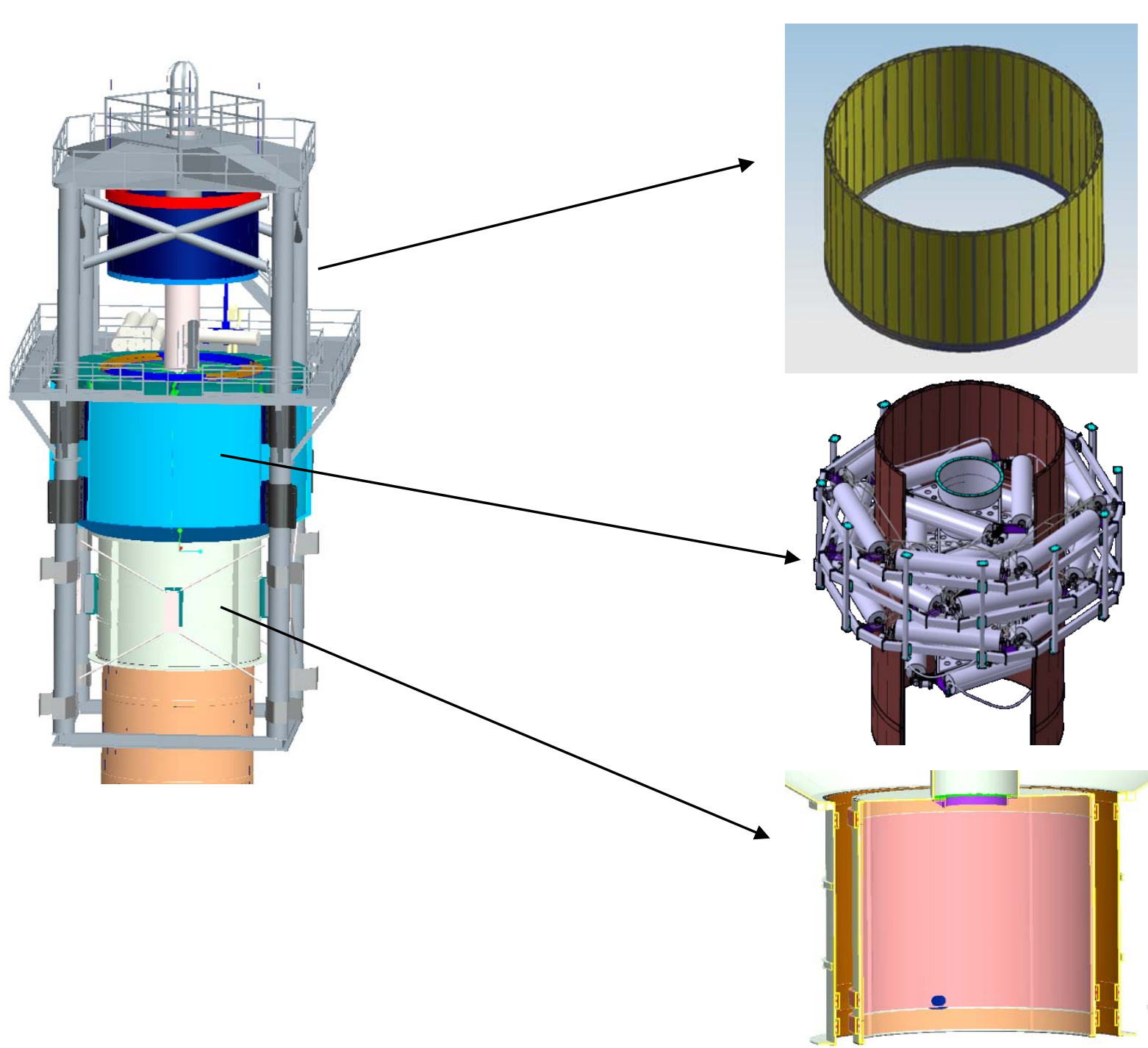

1. Core plank production and assembly into core rings

2. Fabric architecture, fabric production, and fabric dispensing mechanisms

3. Molding region and stepwise infusion validation 


\section{VI.A - Validation 1 - Core}

\section{plank production and}

\section{assembly into core rings}

- Pictorial summary of core assembly validation

- Pultruded Core Planks

- Shear keys

- Shear key tooling

- Shear key infusion

- Core assembly adhesive and application equipment

- Representative core ring assembly operations

- Assembling core ring

- First assembled core ring (still showing internal cross-section)

- Staggered planks method of joining adjacent core rings

- Tabular summary of core production and assembly validation results at $4 \mathrm{~m}$ scale 


\section{OJEC \\ Pictorial summary of core assembly validation}
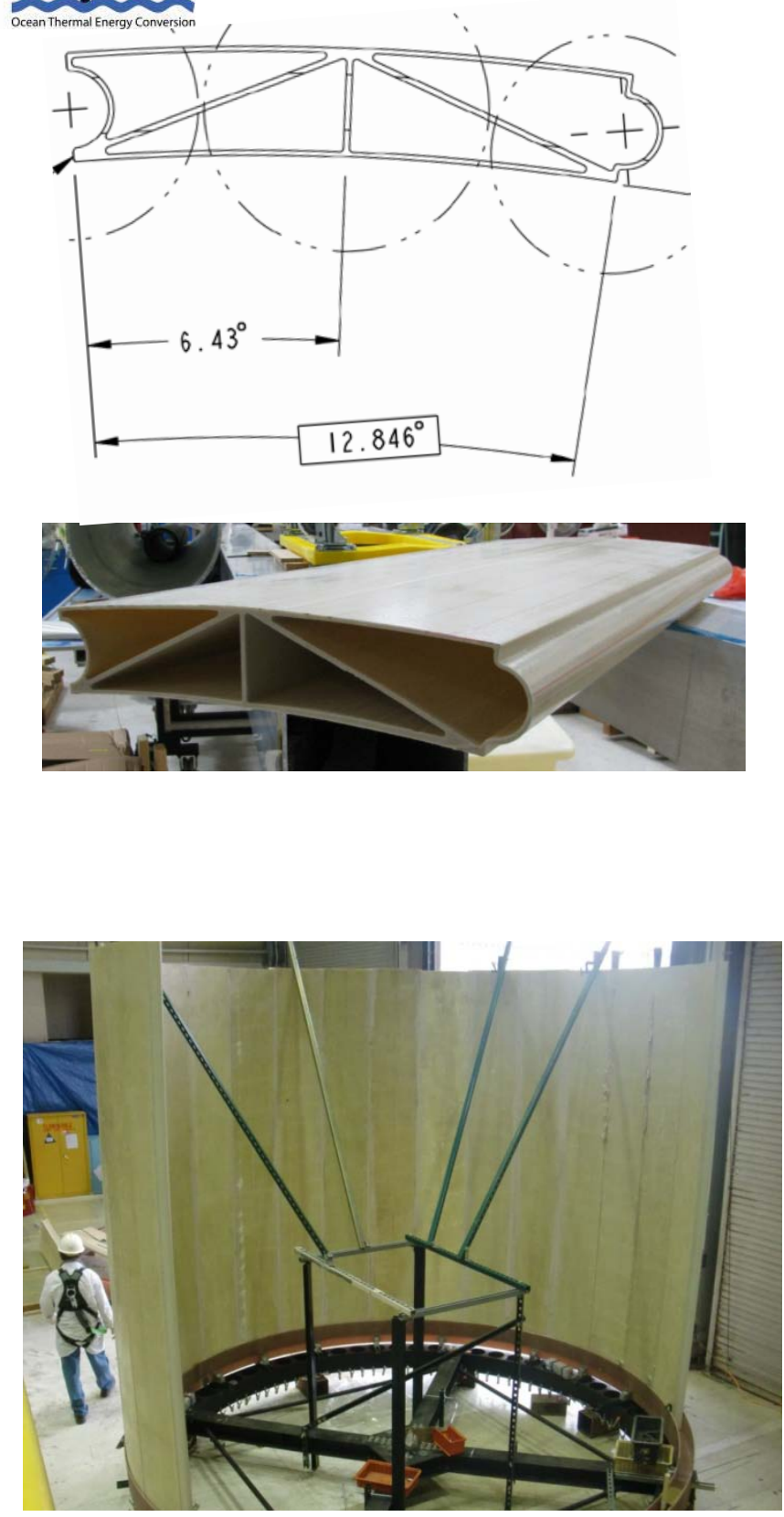
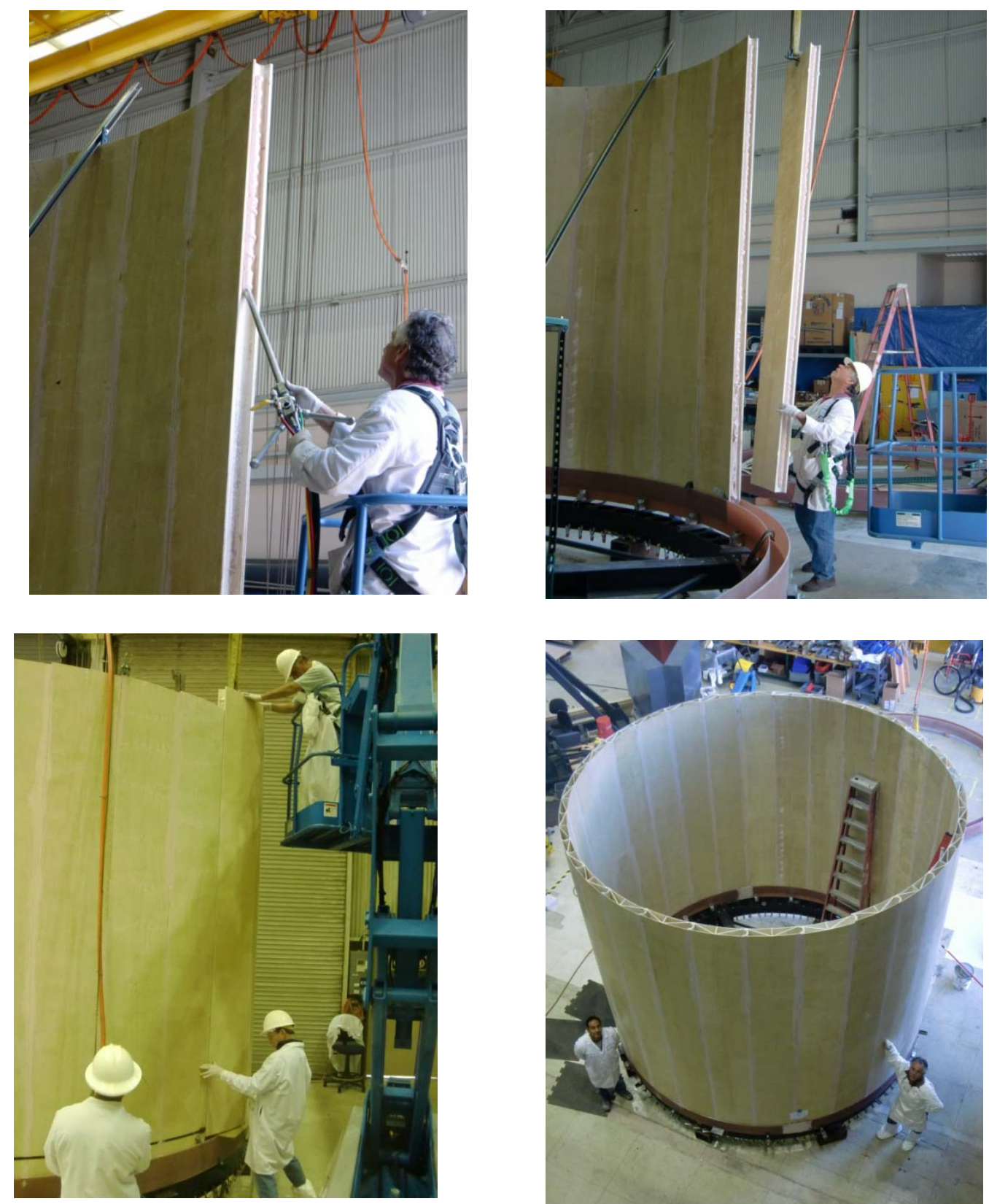

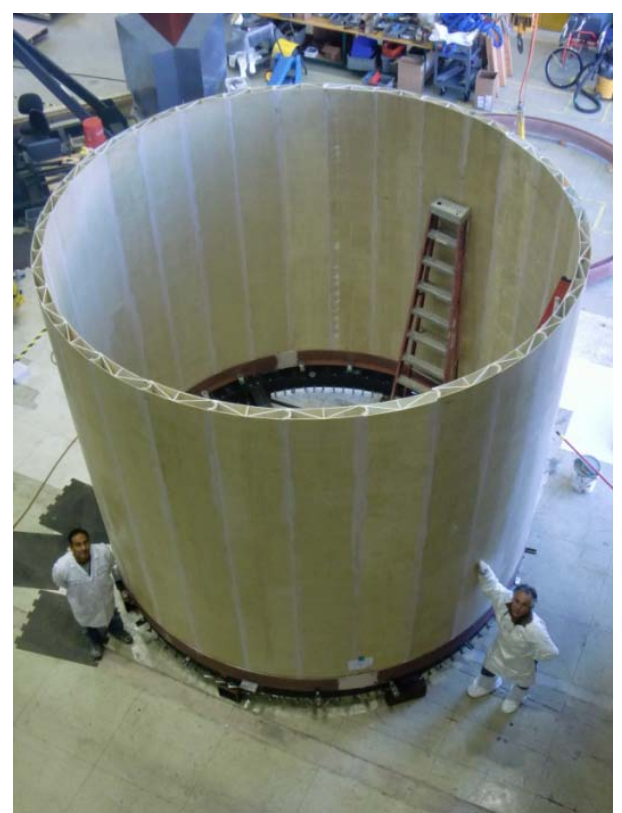




\section{Pultruded Core Planks}

Core plank design

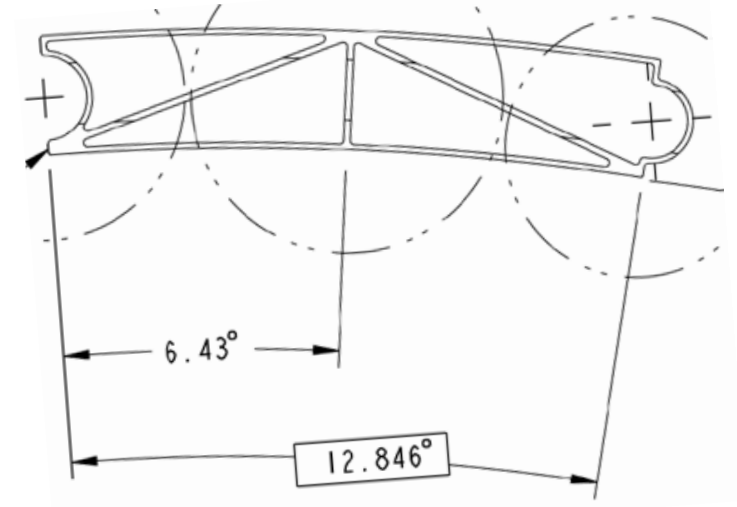

Assembled core ring (28 planks) with shear key at bottom

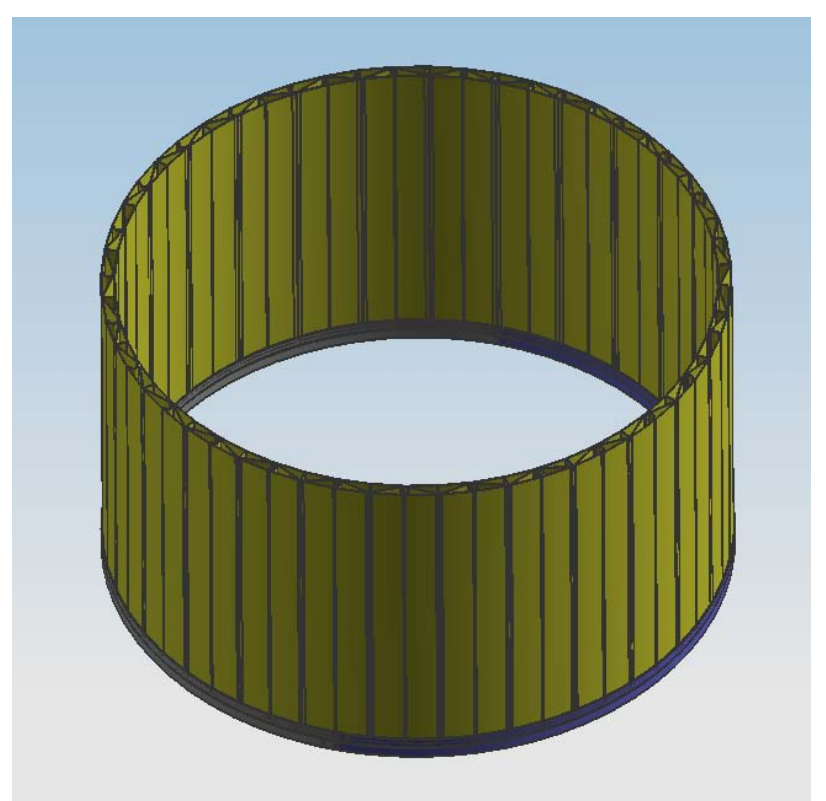

Tongue and groove edges lock adjacent core planks together radially

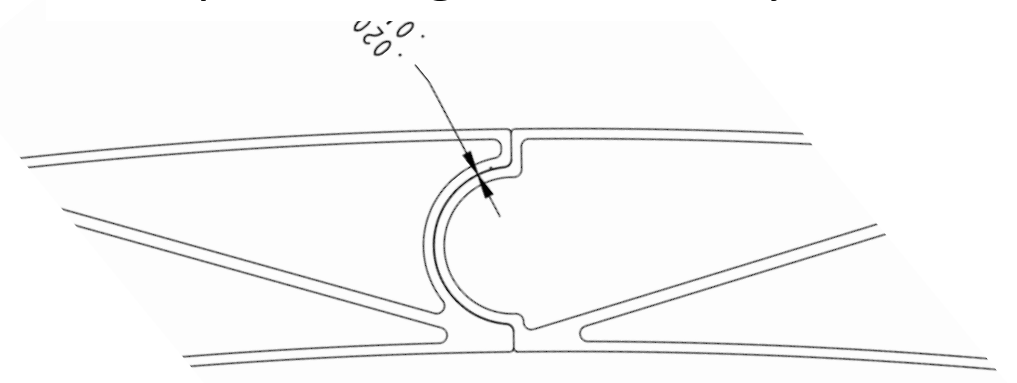

Core planks are made using the same fiberglass material, resin type, and fiber orientation distribution as face sheets -Avoids any stresses due to mismatching elastic constants

\section{Pultruded core plank}

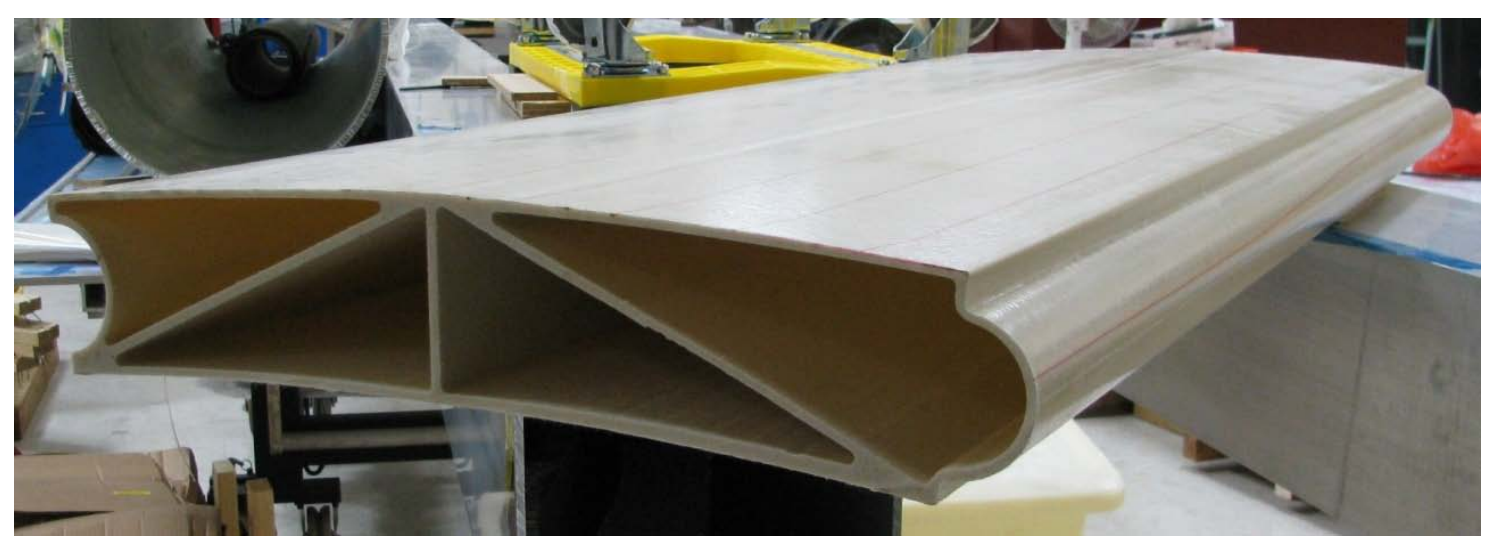

Planks manufactured by Glasforms, Inc, Birmingham, AL 

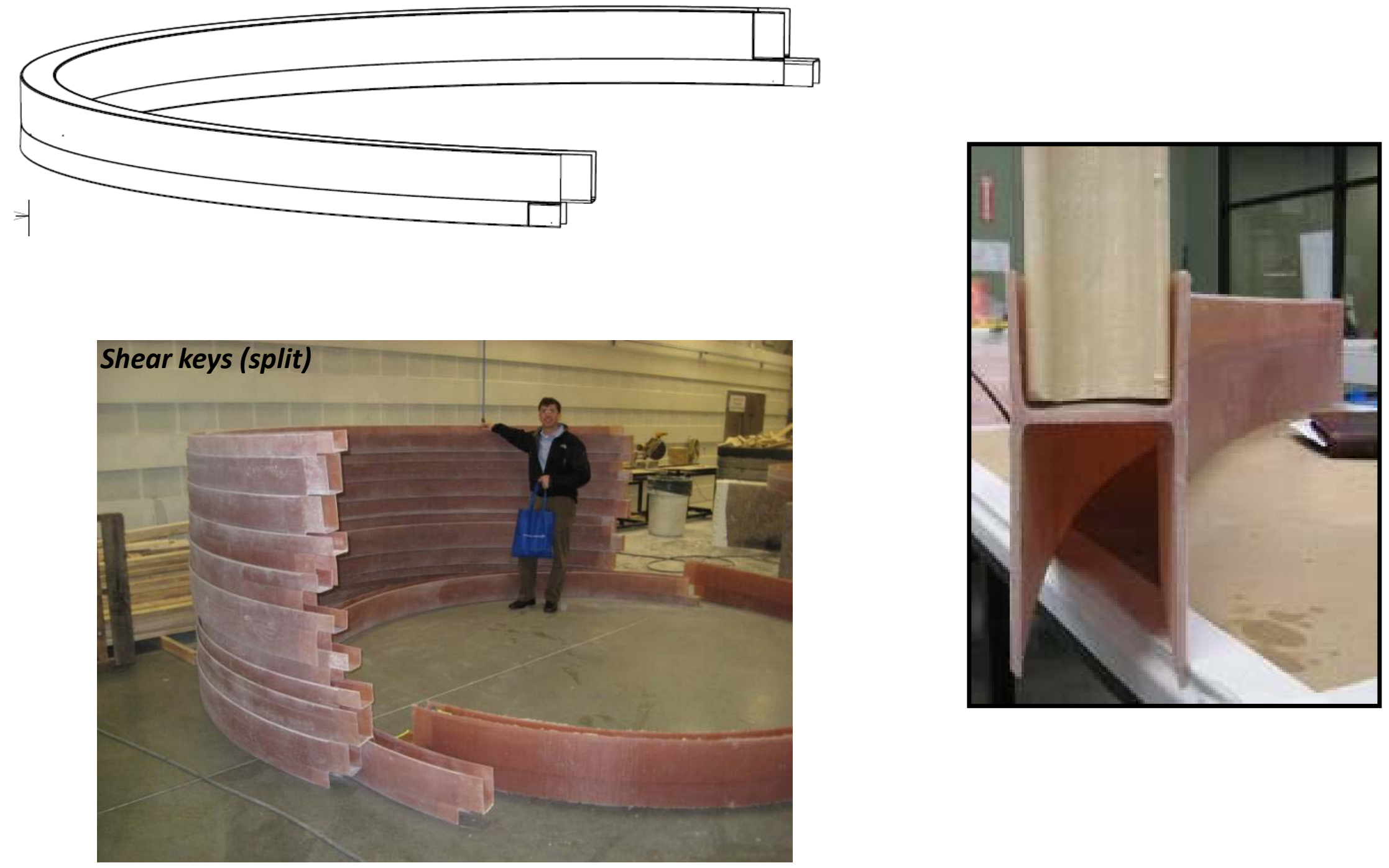

Shear keys manufactured by Janicki Industries, Sedro-Woolley, WA 


\section{Shear key tooling}

(Putty over foam over wood base on steel frame)

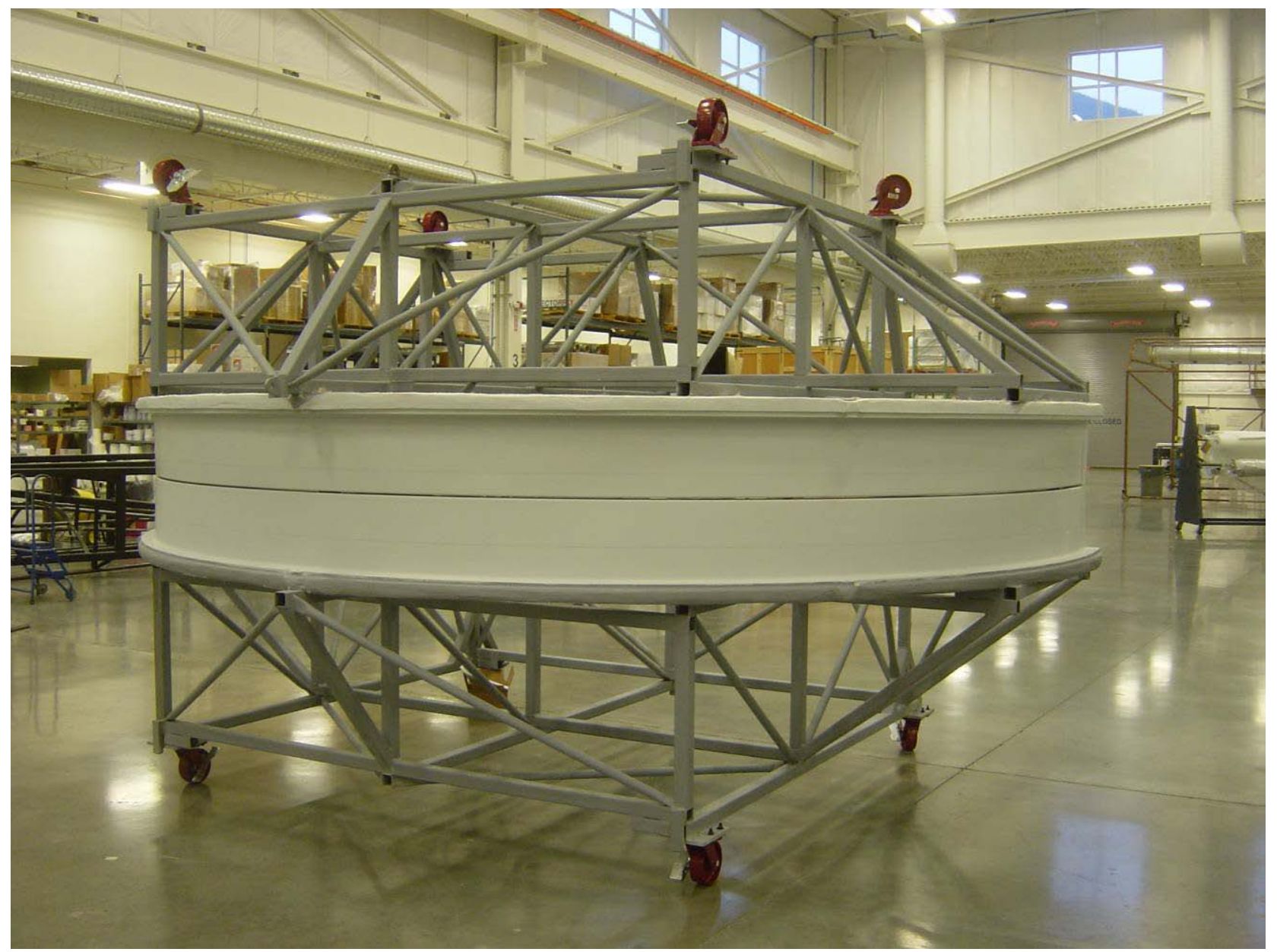

Shear key tooling designed and manufactured by Janicki Industries, Sedro-Woolley, WA 


\section{OIE}

\section{Shear key infusion}

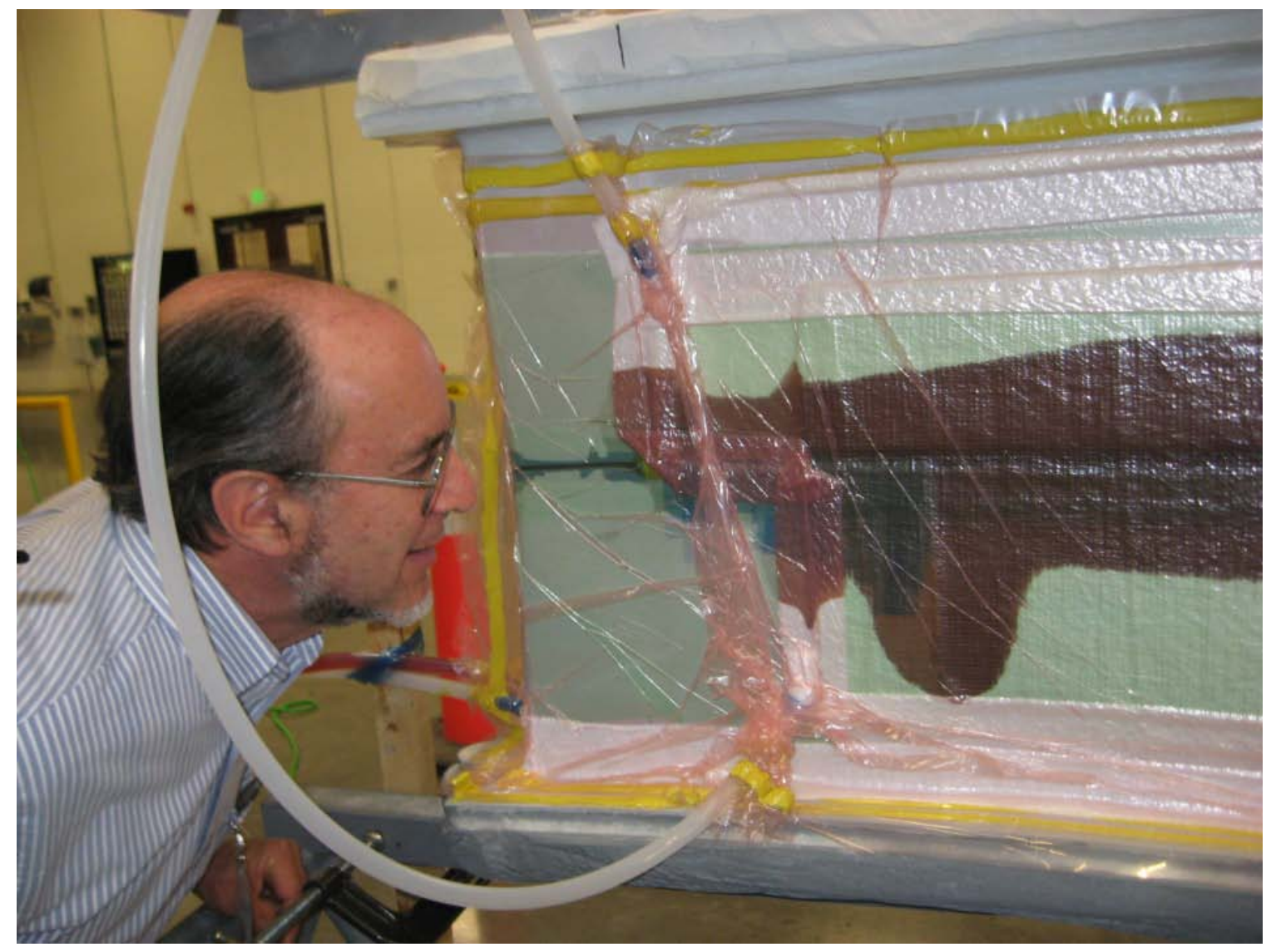

Work done at Janicki Industries, Sedro-Woolley, WA 


\section{Core assembly adhesive and application equipment}

A COTS thick putty adhesive was selected based on the following behavior *:

-Even a $1 / 2$ " bead stays in place vertically

-Squeezes out well to fill the bondlines between planks

A COTS mixing and dispensing pump designed for thick adhesives was used

* Major requirement was fabricability of large assembly, not strength, because in the final CWP the face sheets hold the planks together. 


\section{OJEC Representative core ring assembly operations}
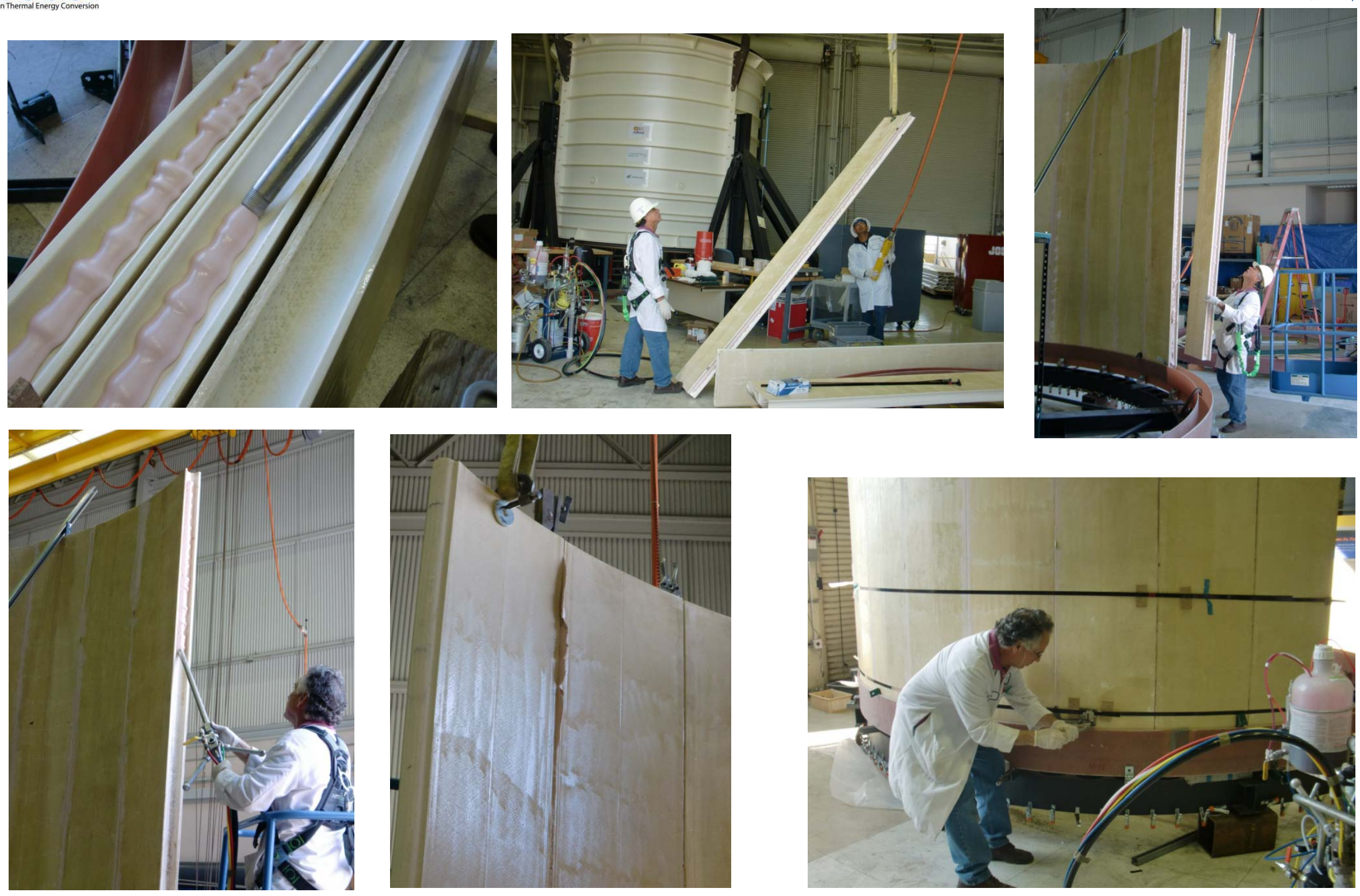


\section{OJEc}

\section{Assembling core ring}
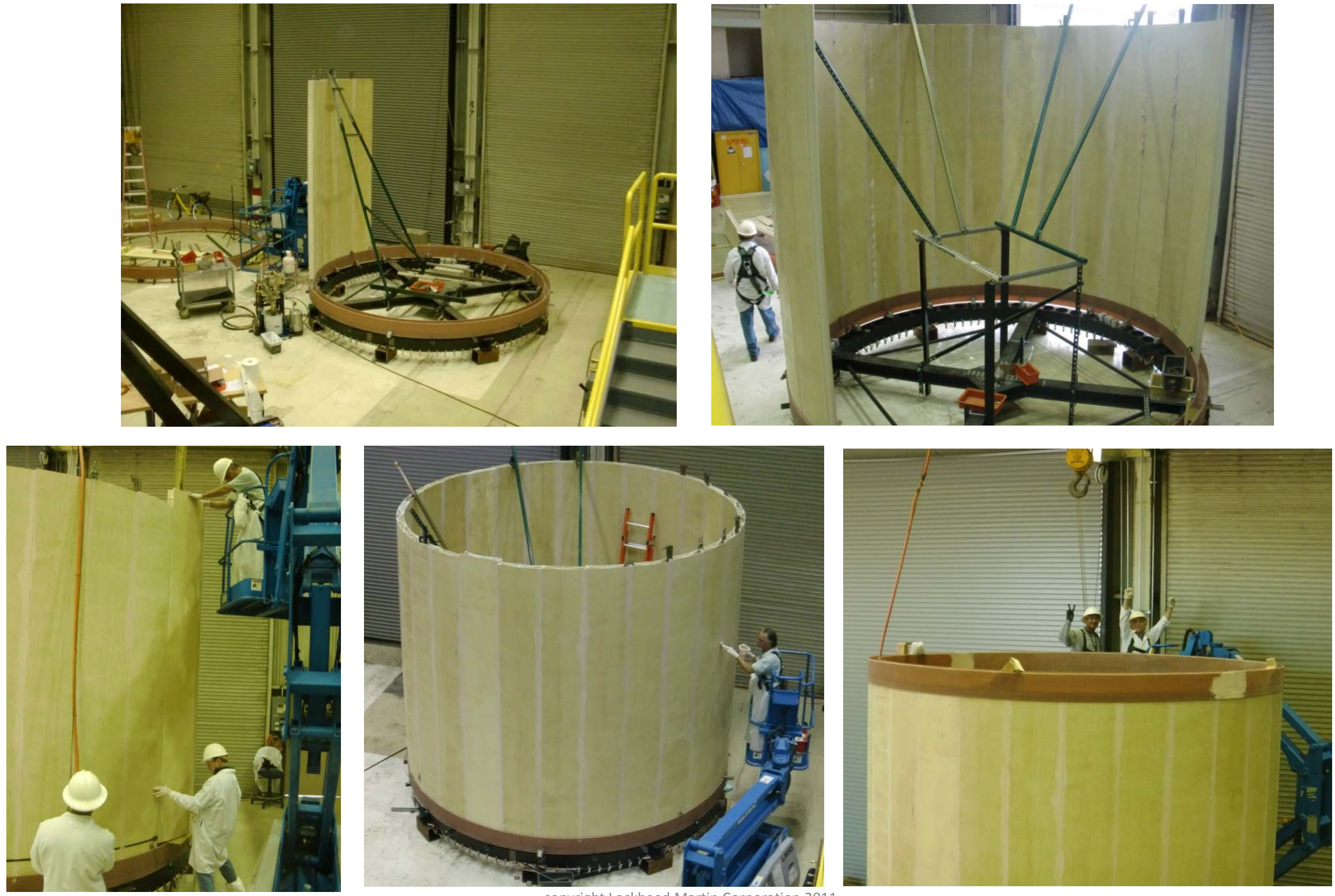
First assembled core ring (still showing internal crosssection)

October 27, 2010 


\section{Staggered planks method of joining adjacent core rings}

(instead of shear keys) - p. 1 of 2

\section{Advantages}

- Direct transfer of core axial loads through plank edges instead of through face sheets (zero stress concentration in face sheets)

- No protruding elements on inside or outside of core - Eliminates need to seal core planks to shear keys

Initial test: Forming leak-tight longitudinal plank-to-plank joints ${ }^{(1)}$

\section{$\underline{\text { Results }}$}

-Plank-to-plank joints did not leak

-Air leakage through pultrusion wall prevented demonstration of a leak-tight assembly -Some lessons were learned on details of assembly and methods of applying adhesive

\section{Notes}

(1) During face sheet infusion, interior of core will be vented to atmosphere. Any air leaks through joints or planks introduces air into fabric being infused with resin, with risk of voids
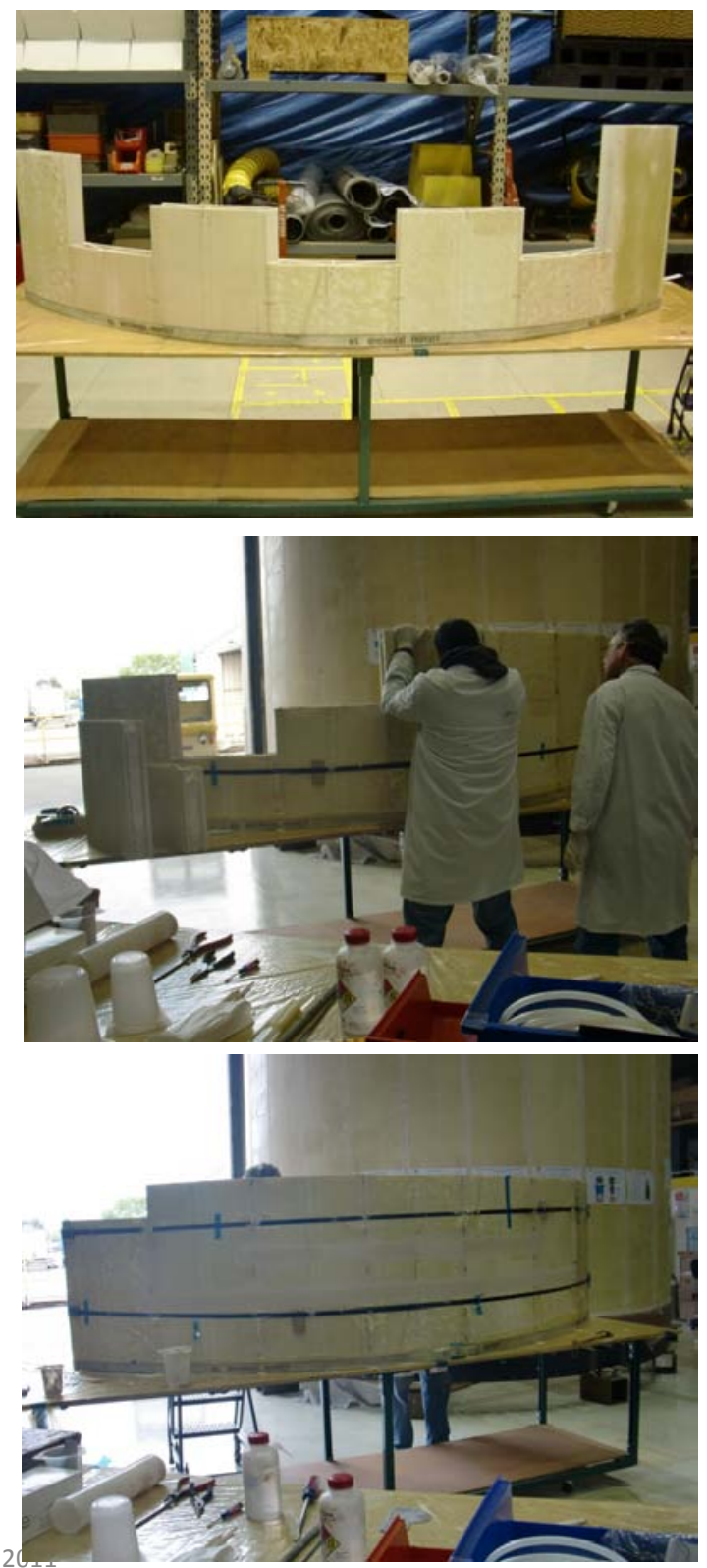


\section{Staggered planks method of joining adjacent core rings - p. 2 of 2}

\section{Second test: Demonstrate a leak-tight staggered-planks assembly}

\section{Procedures:}

- Choose a plank with relatively high surface porosity (as a severe test)

-Apply inexpensive COTS liquid sealant ("slosh compound") to the inside of the plank

- Cut plank into 4 portions

-Assemble two portions of the plank end-to-end, using same thick core assembly adhesive as earlier, incorporating configurational improvements based on lessons learned from $1^{\text {st }}$ test

-Add two continuous planks along edges, to form the staggered joint configuration

-Vacuum bag over inner and outer assembled plank surfaces, and vacuum drop test

\section{Results:}

1. Adhesive application and assembly operations worked well and required minimal labor

2. Initial test after single application of slosh compound: High leak rate

3. Apply slosh compound to cut ends of planks, and re-test: Lower leak rate

4. Apply second coat of slosh compound to insides of all plank portions:

- $\quad$ Still lower leak rate, about 6" Hg in 5 minutes (Close to an acceptable level for a VARTM tool)

- $\quad$ No air leaks were audible at the end-to-end plank joints

\section{Conclusions:}

-A configuration has been developed which enables straightforward adhesive-joining assembly of longitudinally adjacent core planks into a staggered-plank joint, eliminating the shear keys

-The joints between planks are leak-free

-Attention should be given to production of leak-tight pultruded planks for future work. If necessary as a re-work measure at the pultrusion vendor in order to pass acceptance tests, low-cost liquid sealant slosh compound can be used to seal up any porosity in the planks. 


\section{Summary of validation results at $4 \mathrm{~m}$ scale - Core production and assembly}

\begin{tabular}{|c|c|c|c|}
\hline Component and operations & Results and key challenges met & Evidence & Future Needs \\
\hline $\begin{array}{l}\text { Produce custom pultrusions } \\
\text { designed to meet all initially known } \\
\text { loads, and meeting requirements of } \\
\text { stepwise infusion fabrication } \\
\text { process (at Glasforms) }\end{array}$ & $\begin{array}{l}\text { Successful-Achieved proper } \\
\text { fabric guidance, resin wet-out, } \\
\text { and straightness in complex } \\
\text { multi-cell hollow pultruded } \\
\text { shape made from all-fabric with } \\
\text { some sparse fiber directions }\end{array}$ & $\begin{array}{l}\text { Pultruded planks; good fit-up } \\
\text { and dimensional control in } \\
\text { assembled core ring }\end{array}$ & $\begin{array}{l}\text { For fabrication of long } \\
\text { CWP on-the-water, need } \\
\text { to add more ribs to } \\
\text { increase local buckling } \\
\text { strength under pressure of } \\
\text { gripper and bushings }\end{array}$ \\
\hline $\begin{array}{l}\text { Bond pultruded planks into core } \\
\text { ring }\end{array}$ & $\begin{array}{l}\text { Successful - Achieved proper } \\
\text { spacing to fit shear keys. } \\
\text { Achieved good circularity and } \\
\text { diameter control }\end{array}$ & $\begin{array}{l}\text { Results at multiple locations: } \\
+/-1 / 8^{\prime \prime} \text { variability in } \\
\text { diameter over the } 158^{\prime \prime} \\
\text { diameter }\end{array}$ & \\
\hline $\begin{array}{l}\text { Test vacuum tightness of as- } \\
\text { received pultruded planks }\end{array}$ & $\begin{array}{l}\text { Not successful - A random } \\
\text { sample core plank was vacuum } \\
\text { bagged on its outside. Drop } \\
\text { testing showed a 6" Hg drop in } \\
5 \text { minutes. }\end{array}$ & $\begin{array}{l}\text { This was despite the plank } \\
\text { manufacturer's water-tank } \\
\text { testing of best and worst } \\
\text { planks, with application of } \\
\text { resin on the outside of all to } \\
\text { seal them. }\end{array}$ & $\begin{array}{l}\text { Need to improve the leak- } \\
\text { tightness of the core } \\
\text { planks as-pultruded, or if } \\
\text { necessary with } \\
\text { subsequent sealing }\end{array}$ \\
\hline $\begin{array}{l}\text { Test vacuum tightness of plank-to- } \\
\text { plank joints (staggered planks } \\
\text { approach) }\end{array}$ & $\begin{array}{l}\text { Successful - The assembly leak } \\
\text { tightness is as good as the } \\
\text { planks themselves }\end{array}$ & $\begin{array}{l}\text { Same vacuum drop as the } \\
\text { planks themselves. No } \\
\text { audible evidence of air } \\
\text { leakage at longitudinal joints }\end{array}$ & \\
\hline $\begin{array}{l}\text { Produce leak-tight core assembly } \\
\text { by pre-applying a commercial "slosh } \\
\text { sealing compound" inside each cell } \\
\text { of each plank, then assemble into } \\
\text { staggered-planks configuration, and } \\
\text { vacuum test }\end{array}$ & $\begin{array}{l}\text { Successful - Overall drop-test } \\
\text { leak rate of staggered-joint } \\
\text { assembly is close to acceptable } \\
\text { level for VARTM tools. }\end{array}$ & $\begin{array}{l}6 " \mathrm{Hg} \text { vacuum drop in } 5 \\
\text { minutes }\end{array}$ & $\begin{array}{l}\text { Improve the leak-tightness } \\
\text { of the core planks as- } \\
\text { pultruded, and use slosh } \\
\text { compound as a re-work } \\
\text { measure if necessary to } \\
\text { ensure leak-free } \\
\text { pultrusions. }\end{array}$ \\
\hline
\end{tabular}




\section{VI.B - Validation 2 - Fabric architecture, production, overlap splice performance, and fabric dispensing process}

- Pictorial summary of fabric dispensing validation

- VI.B.1 - Fabric architecture

- VI.B.2 - Validation of overlap splice strength

- VI.B.3-Fabric dispensing validation

- Tabular summary of fabric architecture and dispensing validation results at $4 \mathrm{~m}$ scale - 


\section{VI.B.1 - Fabric architecture}

- Custom pre-assembled 3-ply face sheet stitched preform

- Face sheet fabric architecture

- Photo of CWP segment including one fabric splice in each face sheet 


\section{Custom pre-assembled 3-ply face sheet stitched preform}

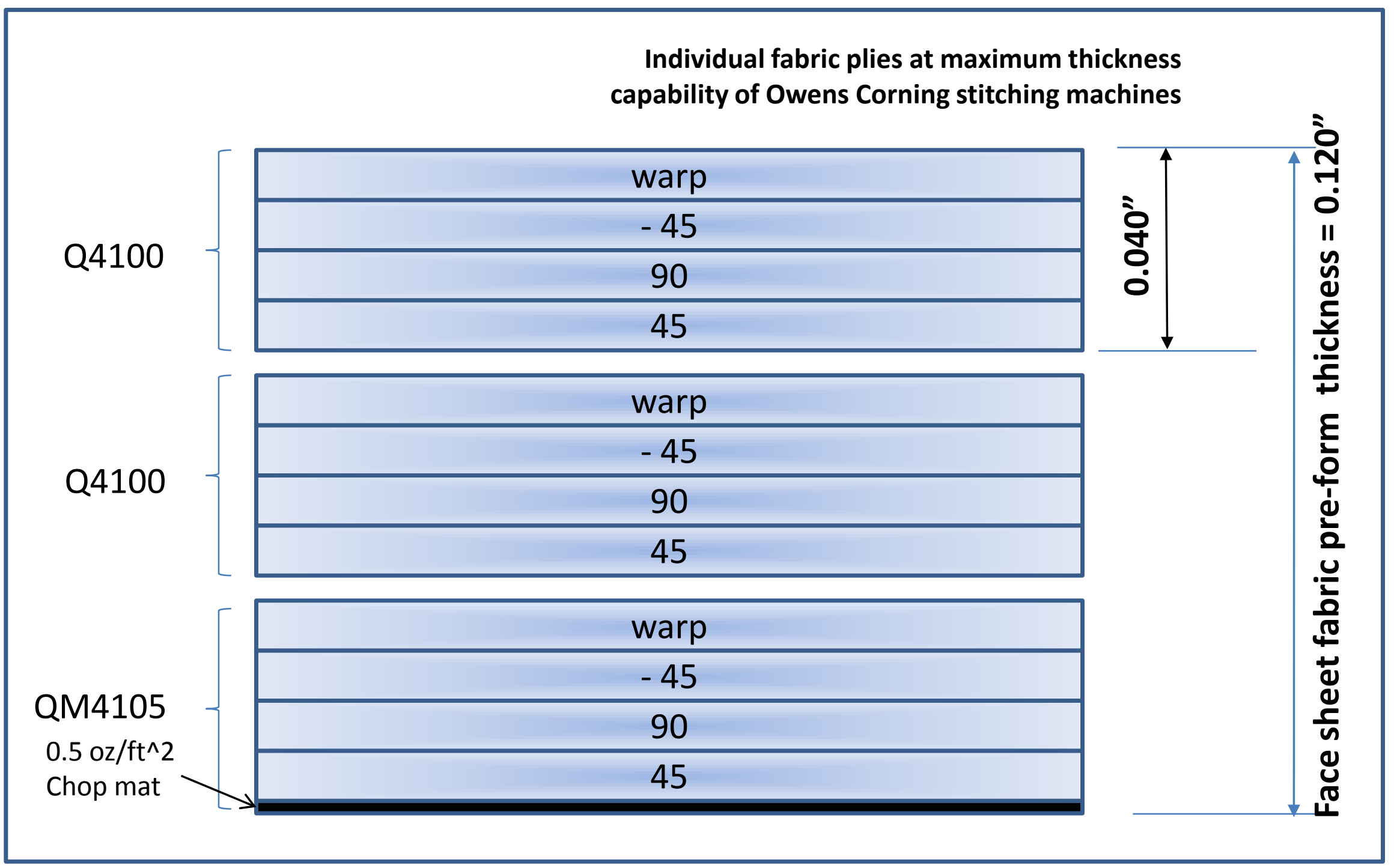

Pre-assembling the fabric into two thick preforms simplifies the fabric dispensing apparatus 


\section{Face sheet fabric architecture}

Each face sheet is divided into two major layers (preforms) of stitch-assembled face sheet fabric

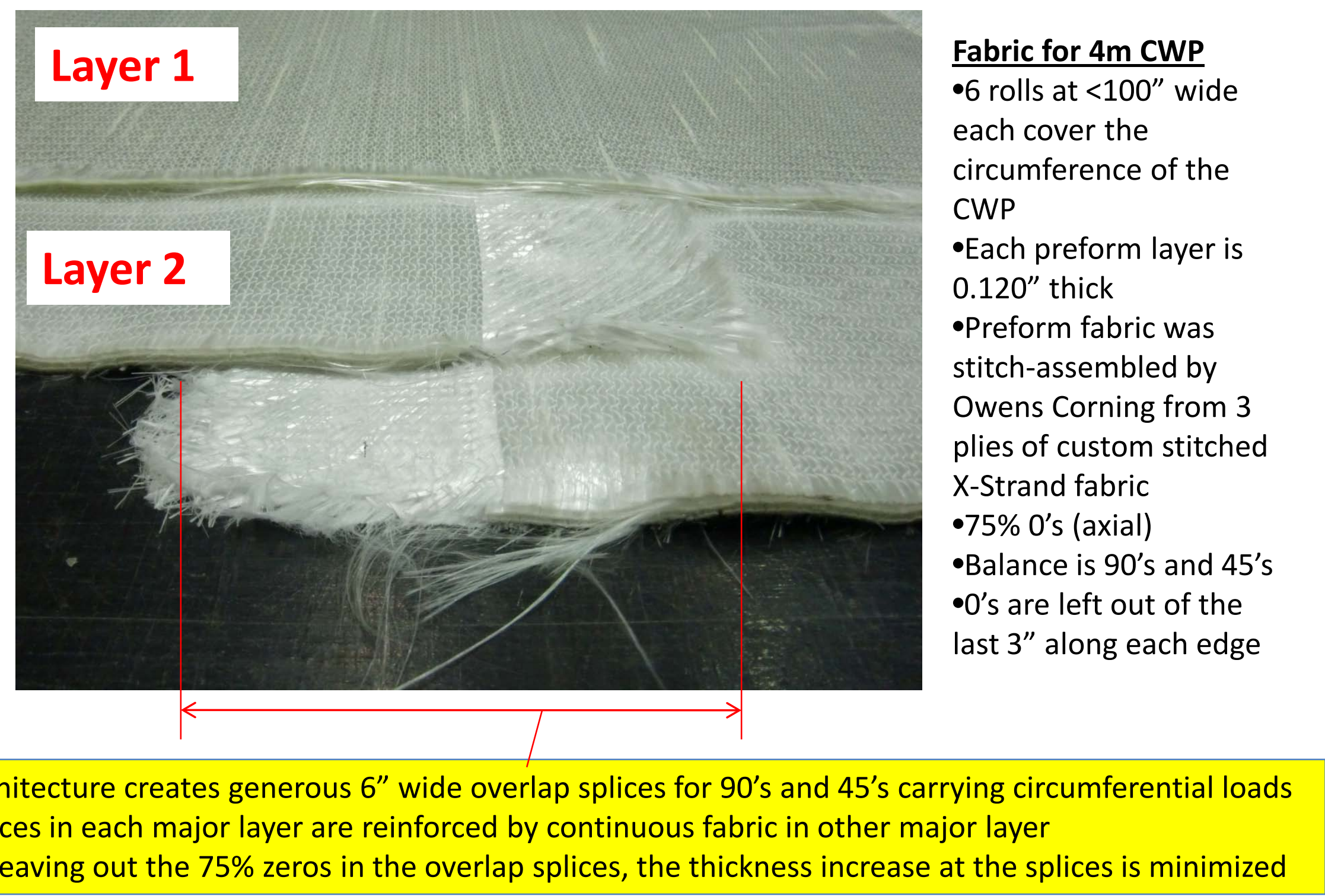

-Architecture creates generous 6" wide overlap splices for 90's and 45's carrying circumferential loads - Splices in each major layer are reinforced by continuous fabric in other major layer

-By leaving out the $75 \%$ zeros in the overlap splices, the thickness increase at the splices is minimized 


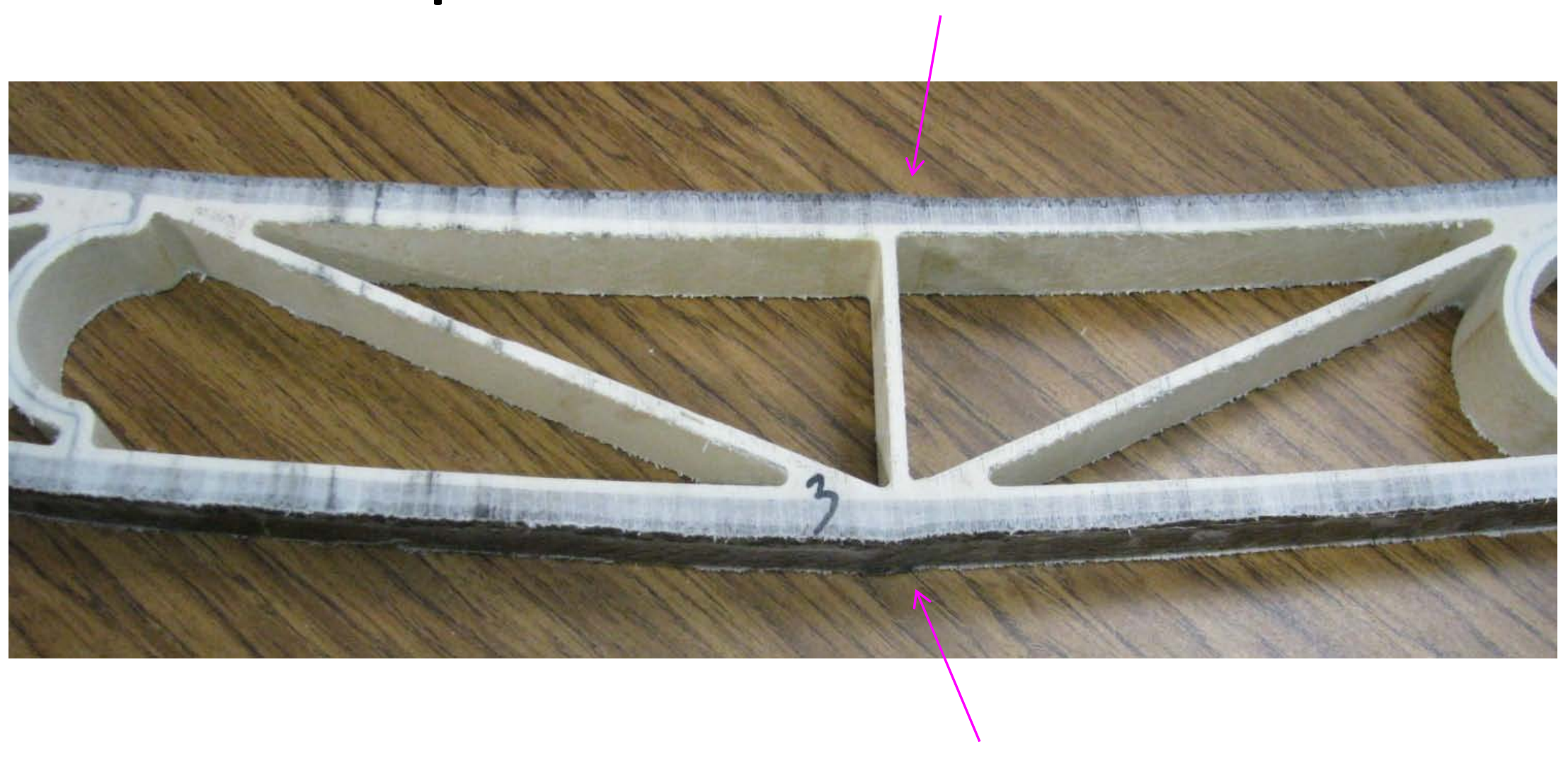

Thickness increase at face sheet fabric splices is barely detectable, and presents no problem going through apparatus, gripper, and bushings 


\section{VI.B.2 - Validation of overlap splice strength}

Under a parallel LM OTEC program sponsored by the US Naval Facilities Command, sections of our CWP design were fabricated and tested under local external pressure, to validate the predictions of its local buckling resistance. The validation was successful, and is described fully in the Technical Development Report of that program.

For one of the three fabricated specimens, we included overlap splices per our fabric architecture. As shown in the next figure, that specimen failed at a location away from the splice (and at about the predicted failure load). This indicates that the splice regions held the required in-plane compressive load successfully, and provides initial validation of our fabric architecture. 


\section{OEE Validation of fabric overlap splice strength}

Local pressure buckling test on section of $4 m C W P$
Testing done by Makai Ocean Engg. under LM program N62583-09-C-0083 sponsored by the US Navy Facilities Command

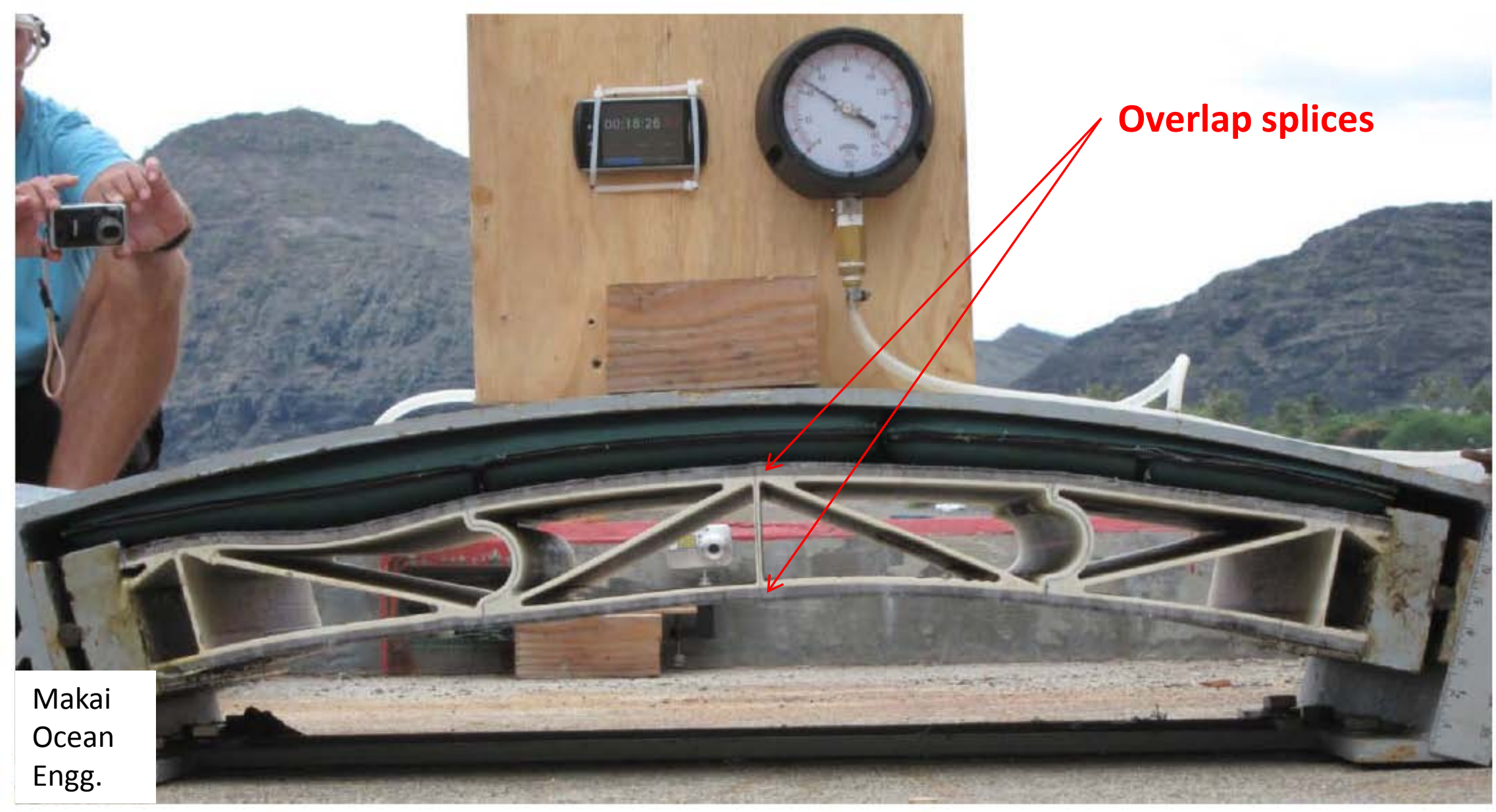

The specimen failed away from the splices, at about the expected pressure. The fabric splices held the required in-plane compressive load. The concept is validated 


\section{VI.B.3- Fabric dispensing validation}

- Configuration of fabric and RDM rolls

- Apparatus during assembly

- Assembled apparatus

- Fabric dispensers computer control system

- Testing constant-payout-tension behavior

- Outer fabric dispensers (typical)

- Outer fabric dispensing, with formation of typical overlap splice

- Inner fabric dispensers (typical)

- Inner fabric dispensing, with formation of typical overlap splice

- Validation of fabric dispensing accuracy

- Tabular summary of fabric architecture and dispensing validation results at $4 \mathrm{~m}$ scale 


\section{OJEC Configuration of fabric and RDM rolls}

\section{Inner}

4

Can put all rolls for any one layer at the same level

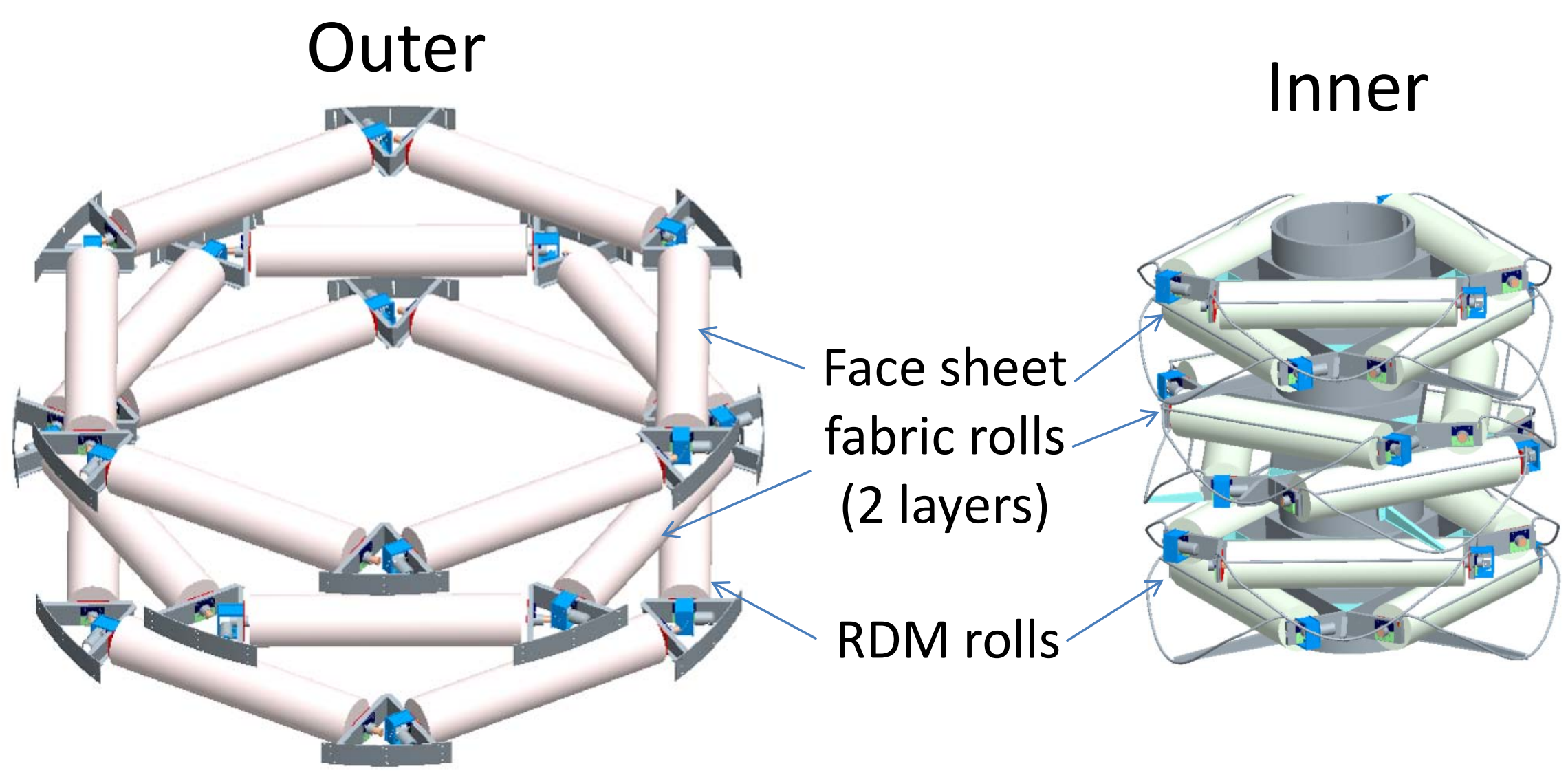

Need to put all rolls for any one layer on two adjacent levels 


\section{OIEC}

\section{Apparatus during assembly}

Outer dispensers support frame

Inner dispensers support frame

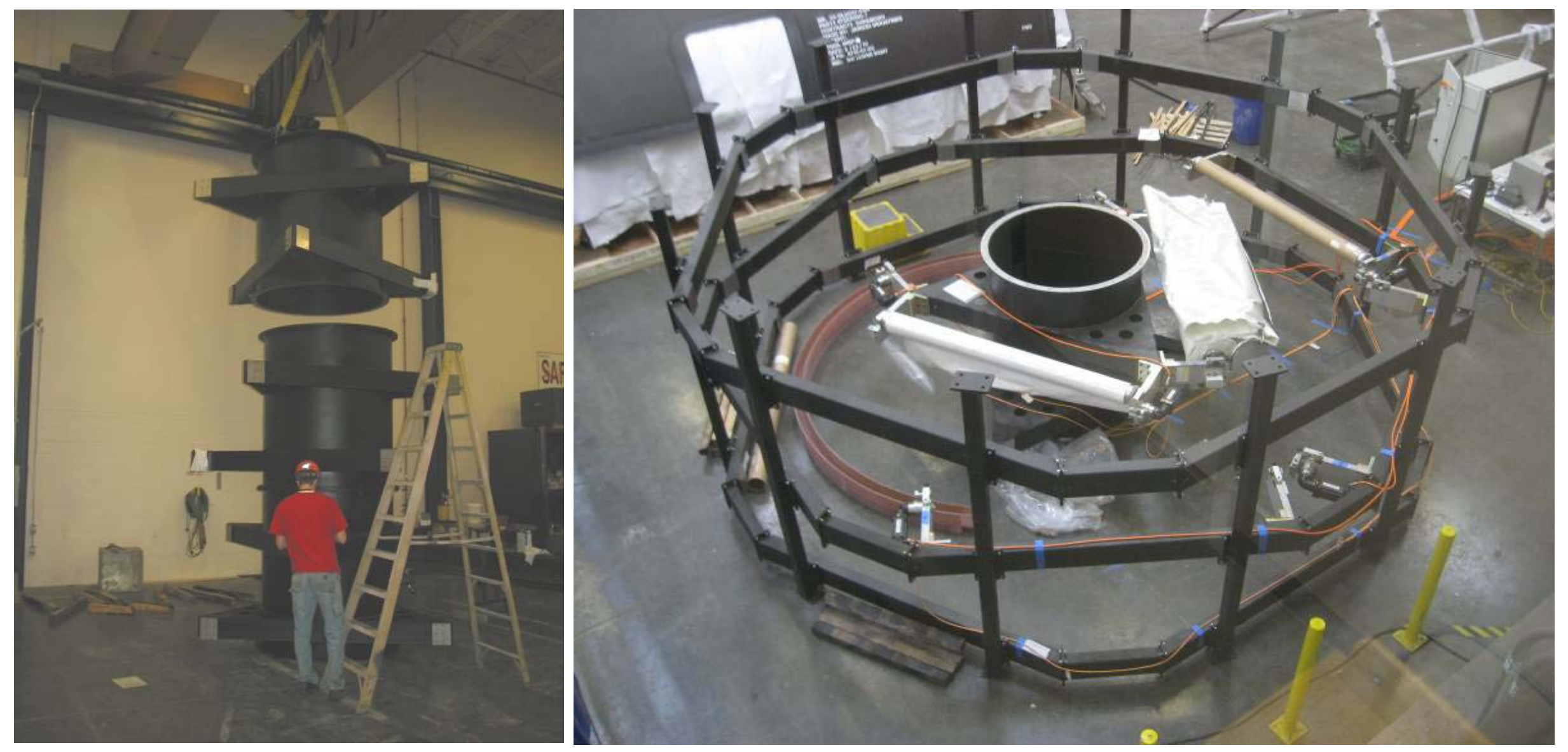




\section{Assembled apparatus}

\section{(during validation of outer face sheet dispensing)}

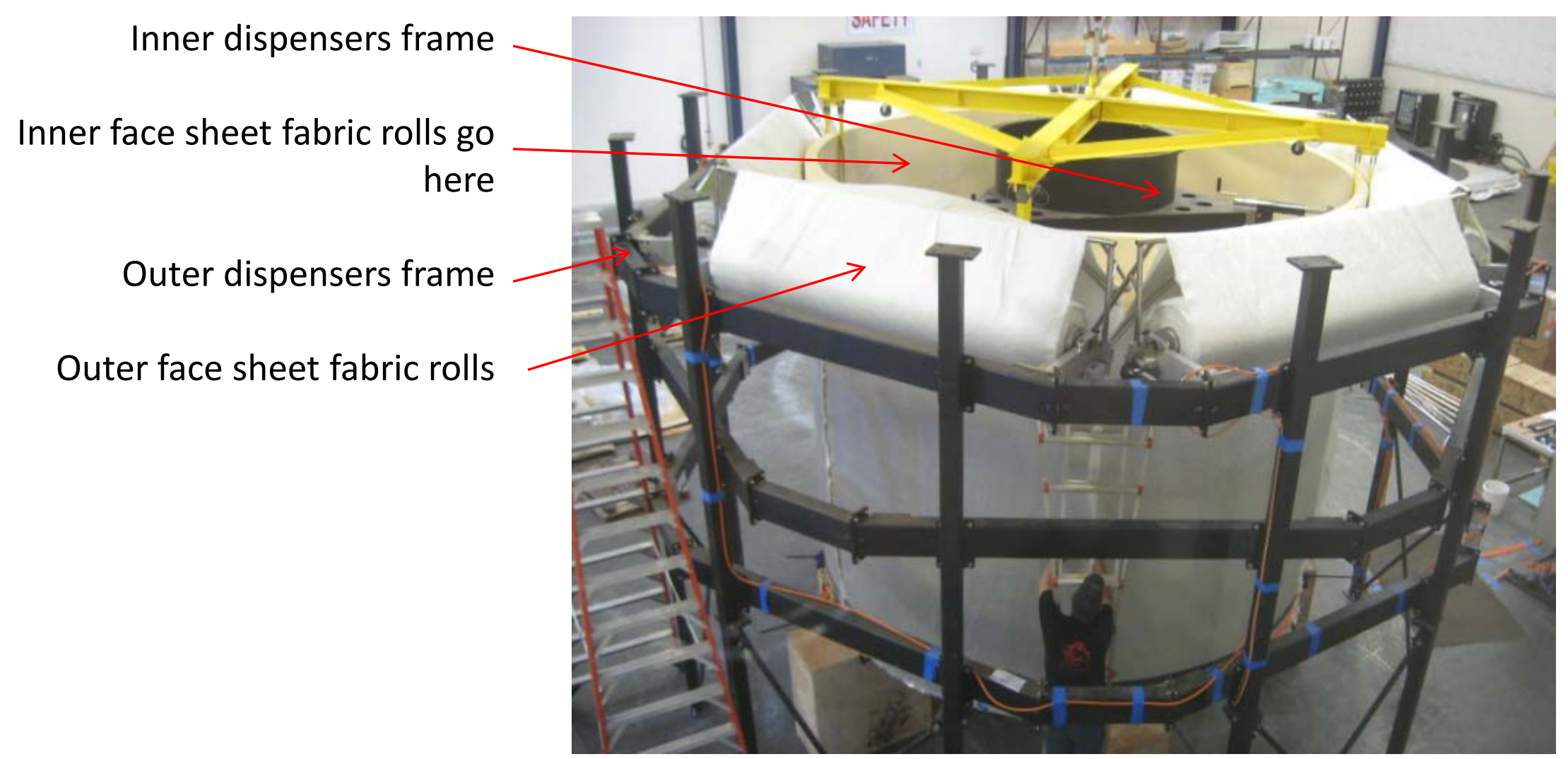

Janicki Industries photo 


\section{Fabric dispensers computer control system}

[D. IndraLogic - NWM_L65.pro - [Main]

[9.9 File Edit Project Insert Extras Online window Help

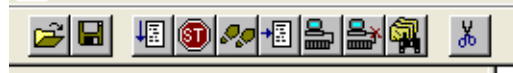

VVisualizations

Man_Config
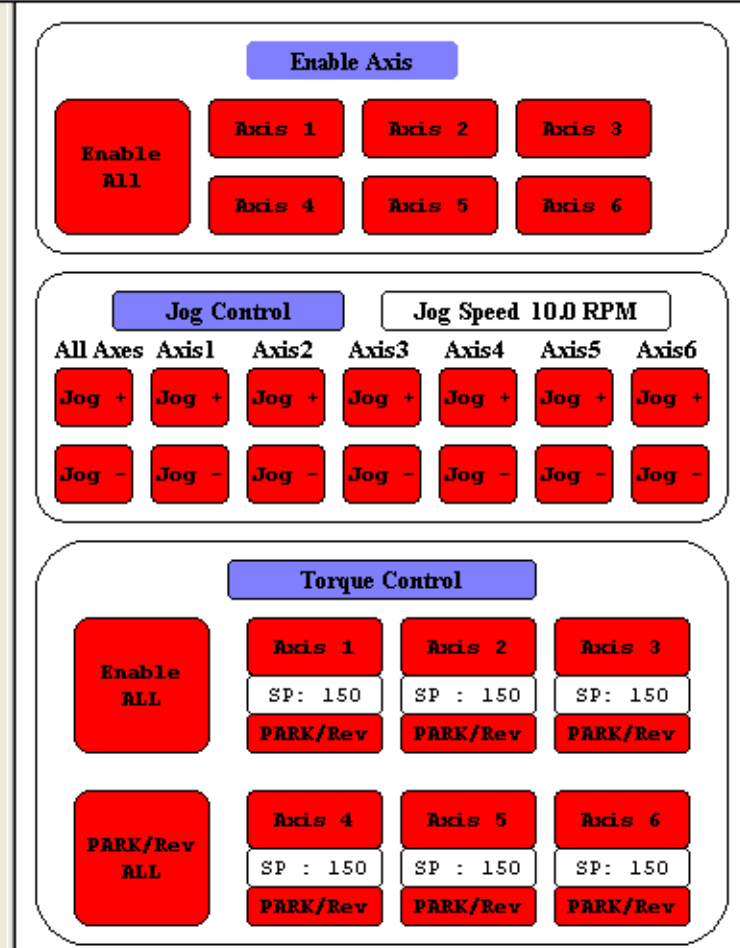
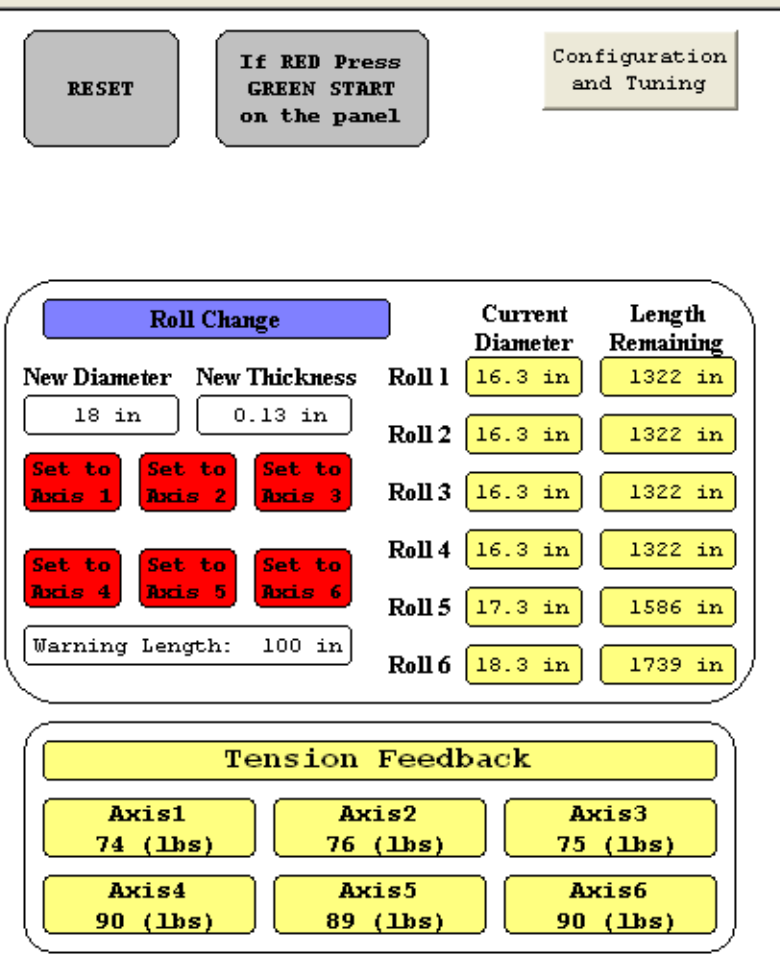

Janicki Industries graphic

Unified control system allows operation of all rolls together or any rolls separately: - Constant tension during payout (or backing up) with velocity controlled by gripper motions - Controlled rotational speed if desired

-Zero motion (braking) at all other times, including loss of power

All specified behaviors have been validated during acceptance testing 


\section{OJEC Testing constant-payout-tension behavior}

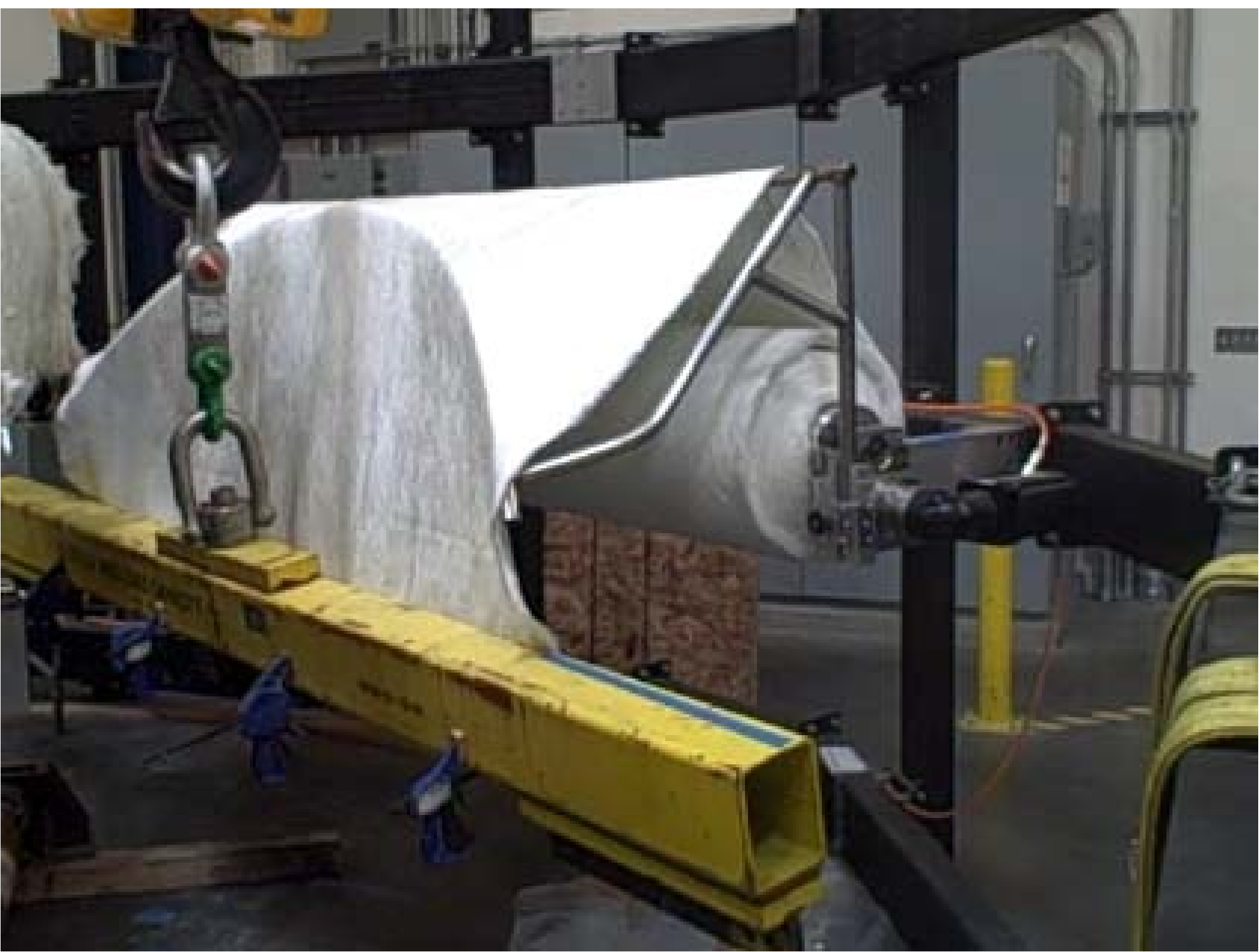




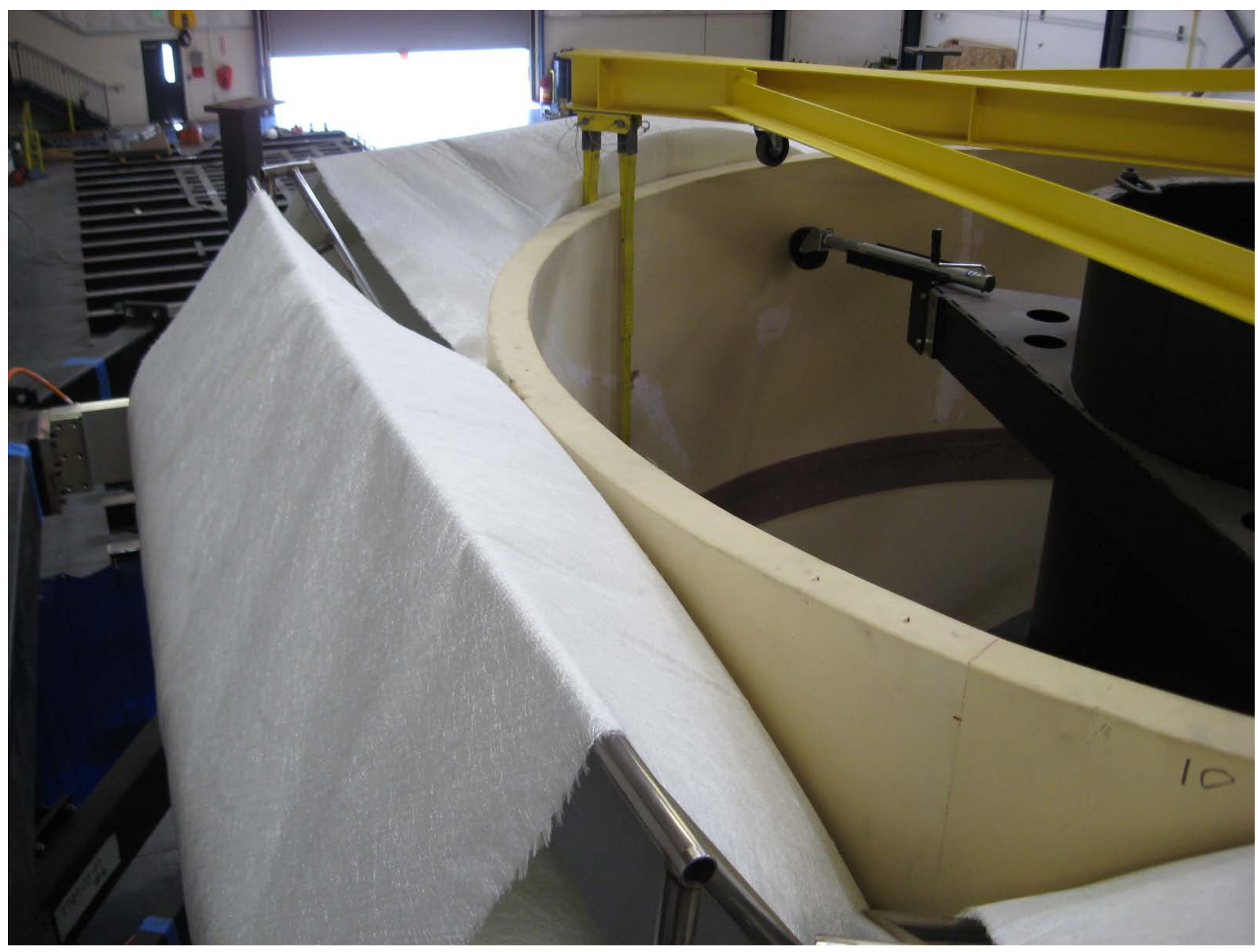



typical overlap splice

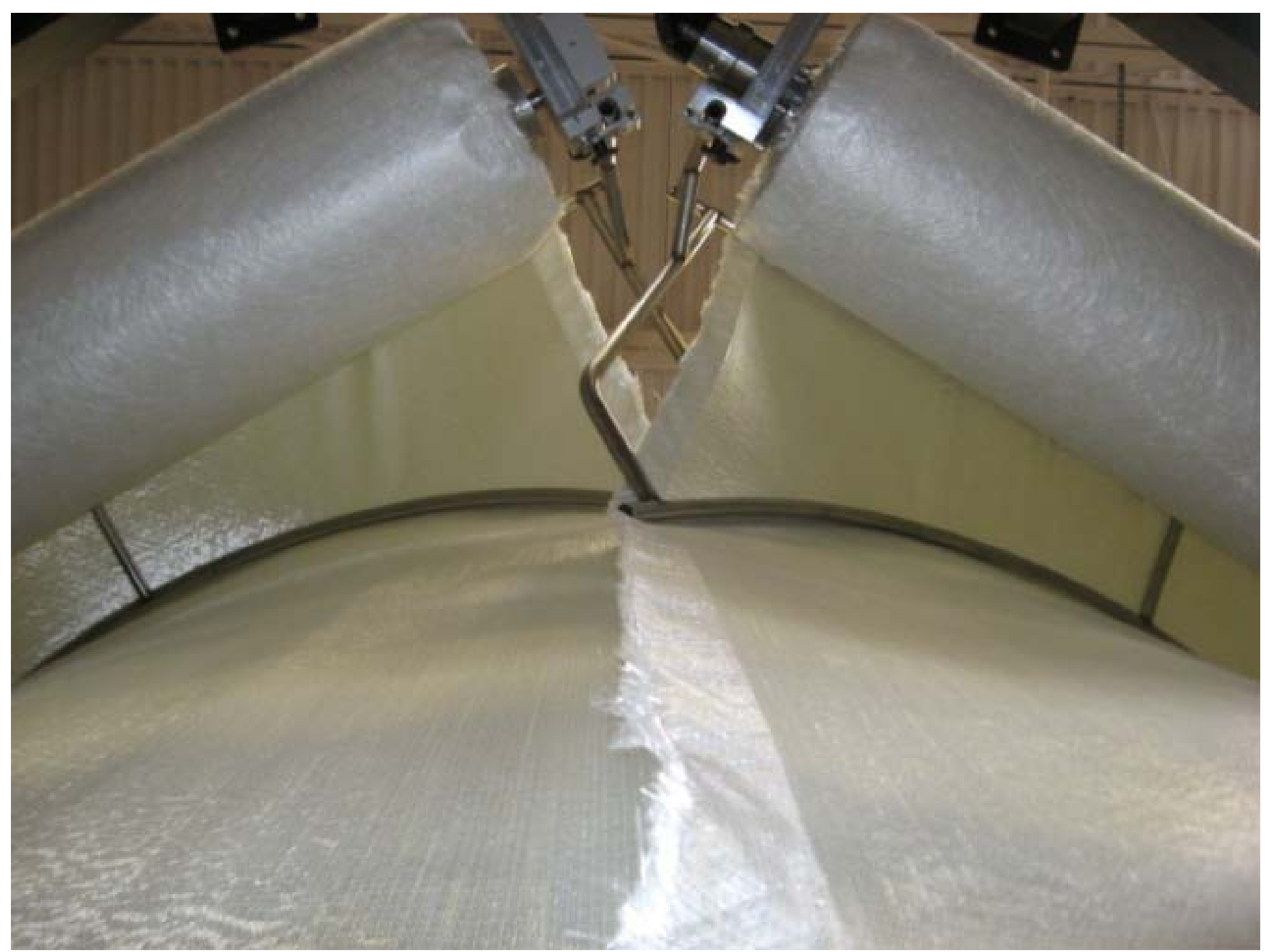




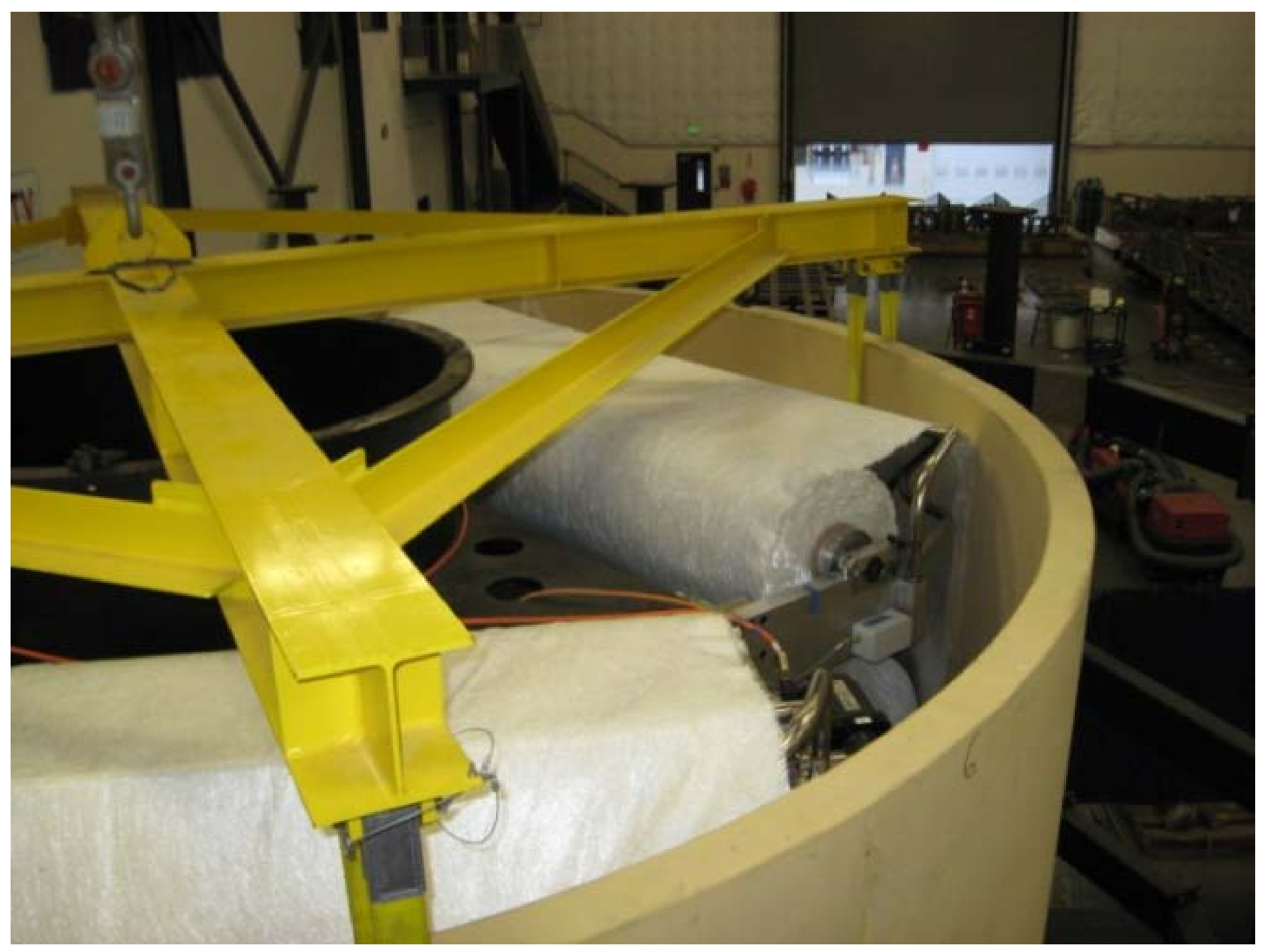



overlap splice

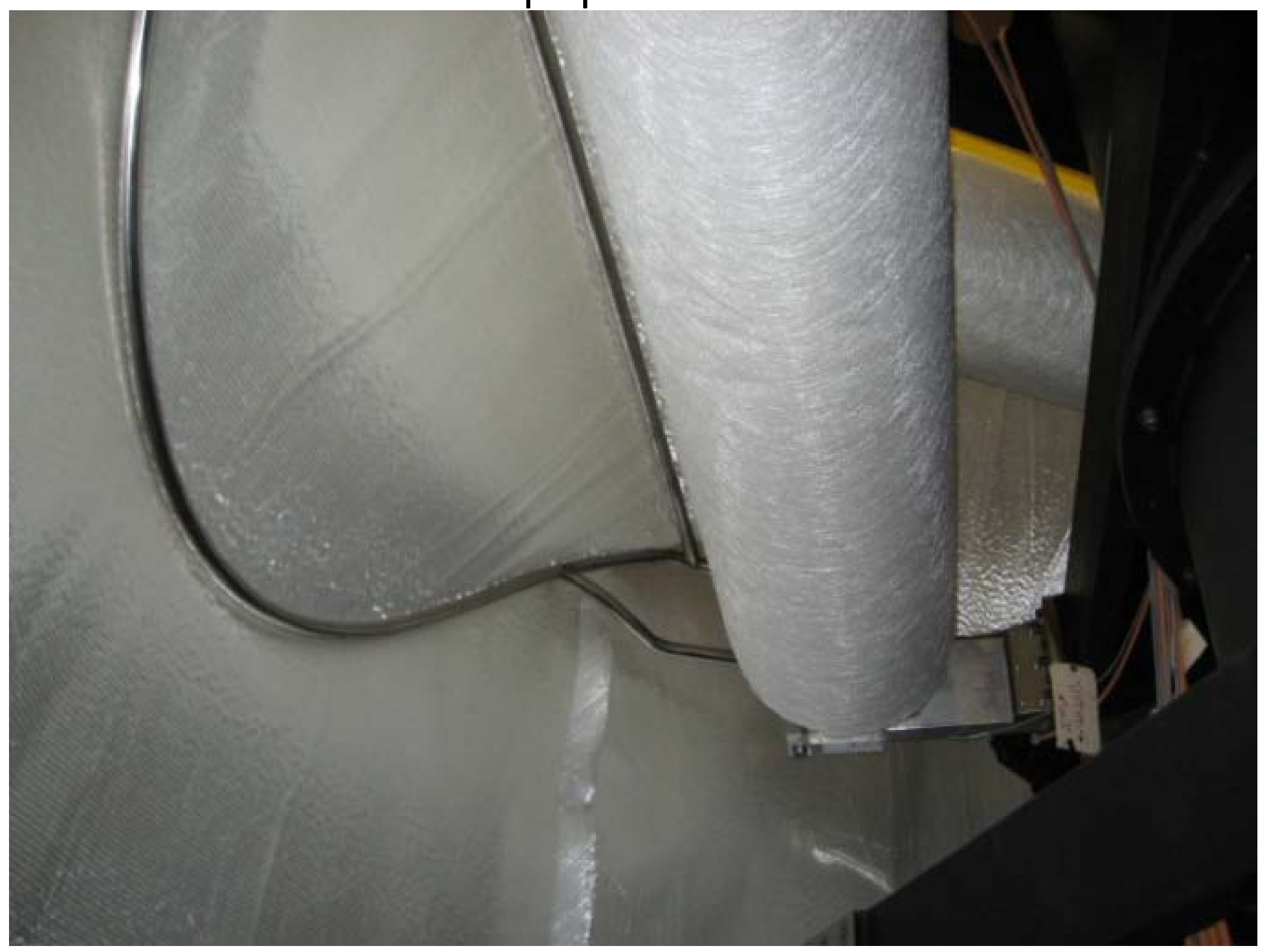




\section{OJEC Validation of fabric dispensing accuracy}

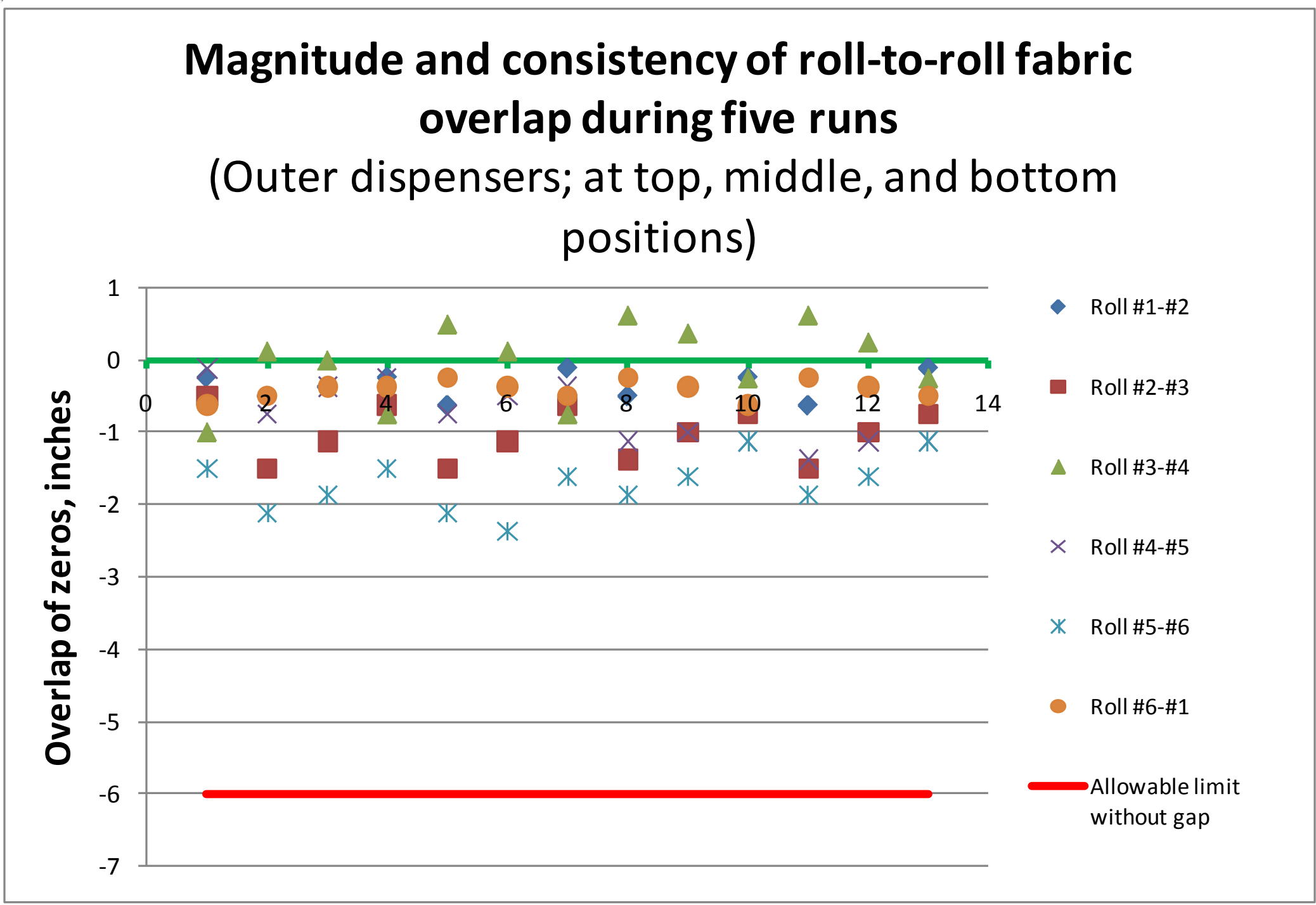

-The apparatus forms consistent overlap splices, well within required tolerances. -The fabric dispensing apparatus is validated. 

architecture and dispensing

\begin{tabular}{|l|l|l|l|}
\hline Component and operations & Results and key challenges met & \multicolumn{1}{|c|}{ Evidence } & Future Needs \\
\hline Overlap splices in face sheets & $\begin{array}{l}\text { Successful - Splice regions are as } \\
\text { strong as the base laminate }\end{array}$ & $\begin{array}{l}\text { Local buckling } \\
\text { specimen failed } \\
\text { away from the } \\
\text { splices }\end{array}$ & \\
\hline $\begin{array}{l}\text { Design and construct complex } \\
\text { apparatus (w. Janicki) }\end{array}$ & Successful & Apparatus & $\begin{array}{l}\text { Core chucks which do not require periodic } \\
\text { re-charging with air pressure }\end{array}$ \\
\hline $\begin{array}{l}\text { Acceptance testing of } \\
\text { apparatus (at Janicki) }\end{array}$ & $\begin{array}{l}\text { Successful - Maintained constant } \\
\text { payout tension despite } \\
\text { variations in "demand" payout } \\
\text { velocity imposed at free end of } \\
\text { fabric }\end{array}$ & $\begin{array}{l}\text { Acceptance } \\
\text { testing COC, } \\
\text { photos, videos }\end{array}$ & \\
\hline $\begin{array}{l}\text { Validate fabric dispensing } \\
\text { operations (at Janicki) }\end{array}$ & $\begin{array}{l}\text { Successful - Variations in width } \\
\text { of fabric overlap are well below } \\
\text { allowable }\end{array}$ & $\begin{array}{l}\text { Validation } \\
\text { testing report, } \\
\text { photos, videos }\end{array}$ & \\
\hline
\end{tabular}




\section{VI.C - Validation 3 -}

Stepwise infusion

\section{molding process}

- Pictorial summary of stepwise infusion molding validation

- VI.C.1 - Apparatus

- VI.C.2 - Initial validation workpiece

- Tabular summary of stepwise infusion molding validation results at $4 \mathrm{~m}$ scale

- Sidebar: Effects of axial forces on large seals 


\section{OYEC Pictorial summary of stepwise infusion molding validation}
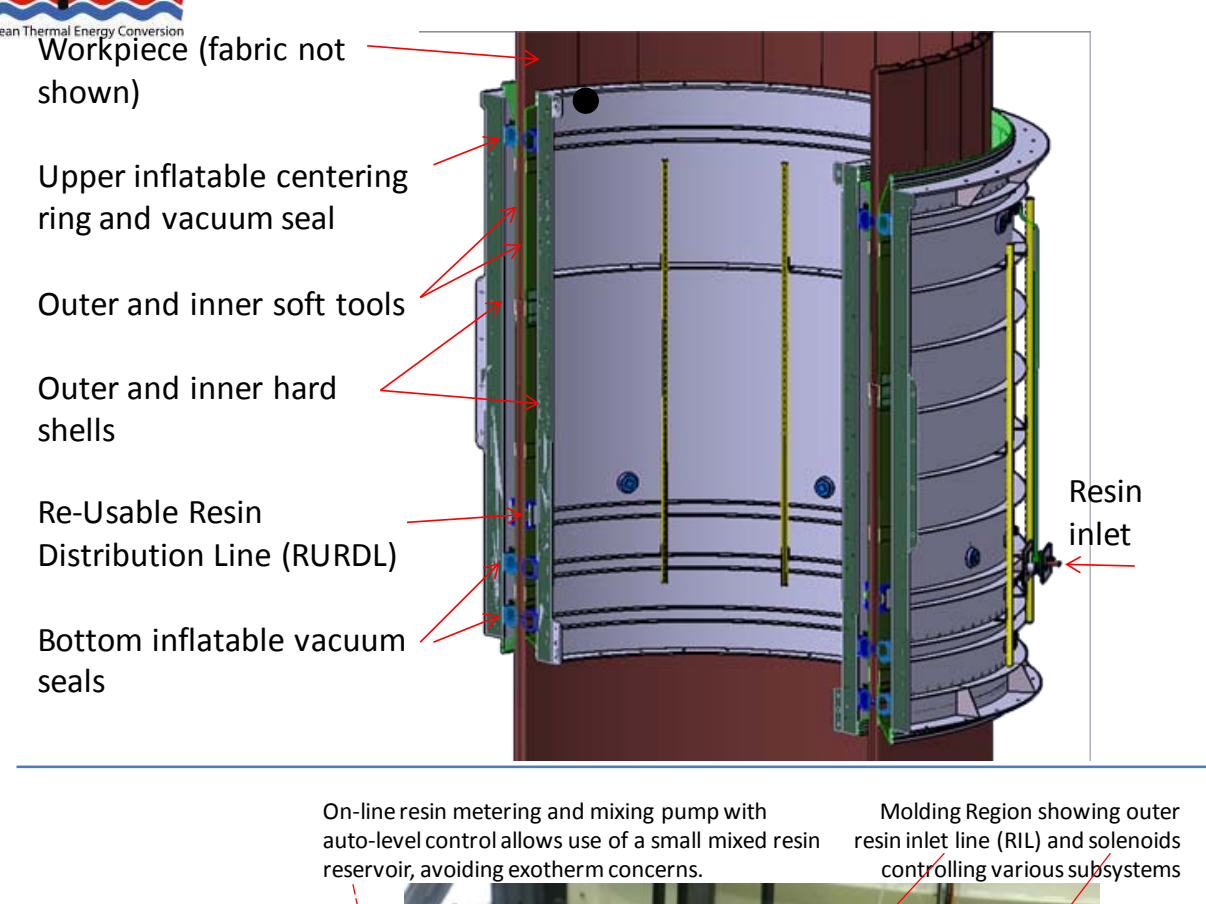

\section{Infusion of workpiece}

-About 1000 lbs. of resin was mixed and infused in 3 shots

-The fill time was within about $20 \%$ of predicted (after correcting the resin viscosity to the low temperatures in the unheated High-Bay)

-The specialized apparatus enablesinfusion to be done by a 2-person crew

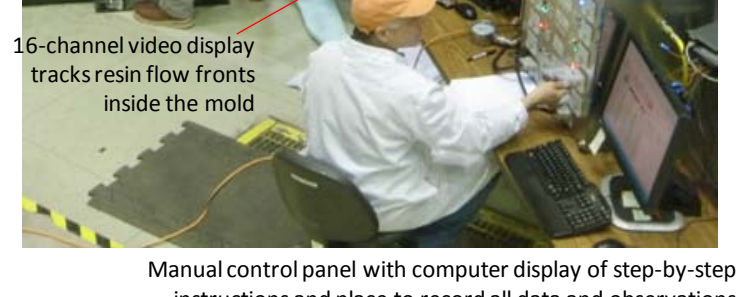

Inner and outer hard shells, soft tools, and upper seals

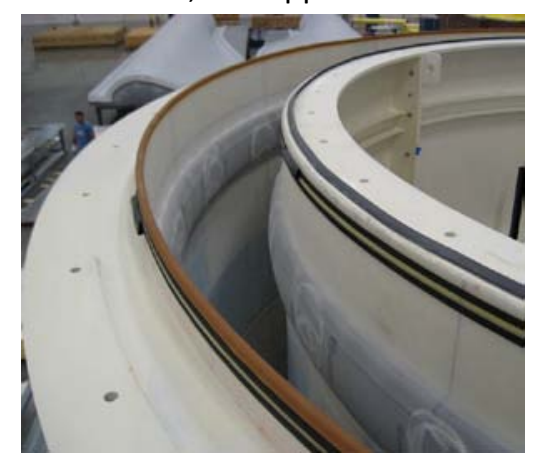

Removing infused and cured workpiece from mold

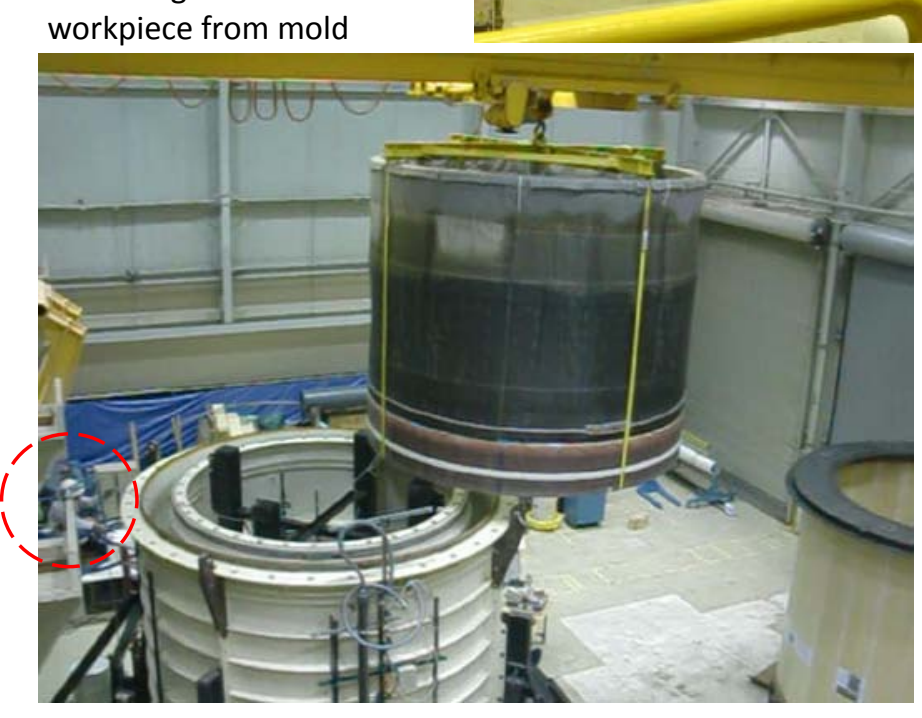

Key result: The knit-line between infusion steps is indistinguishable from the base laminate. The stepwise infusion process is validated!

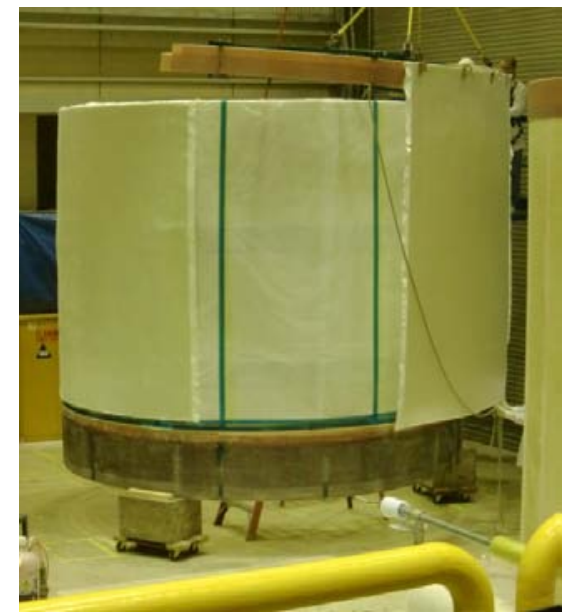

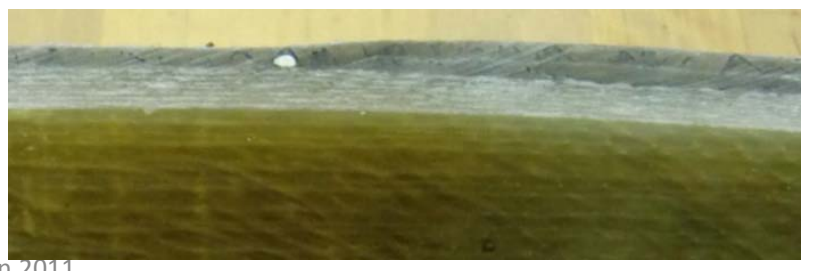

anging outer face sheet fabric on test core 


\section{VI.C.1 - Apparatus}

- Molding Region apparatus elements and subsystems

- VI.C.1.a -- Hard shells (outer and inner)

- VI.C.1.b - Soft tools including Re-Usable Resin Distribution Line (RURDL)

- VI.C.1.C - Resin and resin handling elements

- VI.C.1.d - Acceptance testing at Janicki, transport to Sunnyvale, and installation in B/132 High Bay

- VI.C.1.e - Molding region control system 
Molding Region apparatus elements and subsystems

Workpiece (fabric not shown)

Upper inflatable centering ring and vacuum seal

Outer and inner soft tools

Outer and inner hard shells

Re-Usable Resin

Distribution Line (RURDL)

Bottom inflatable vacuum seals

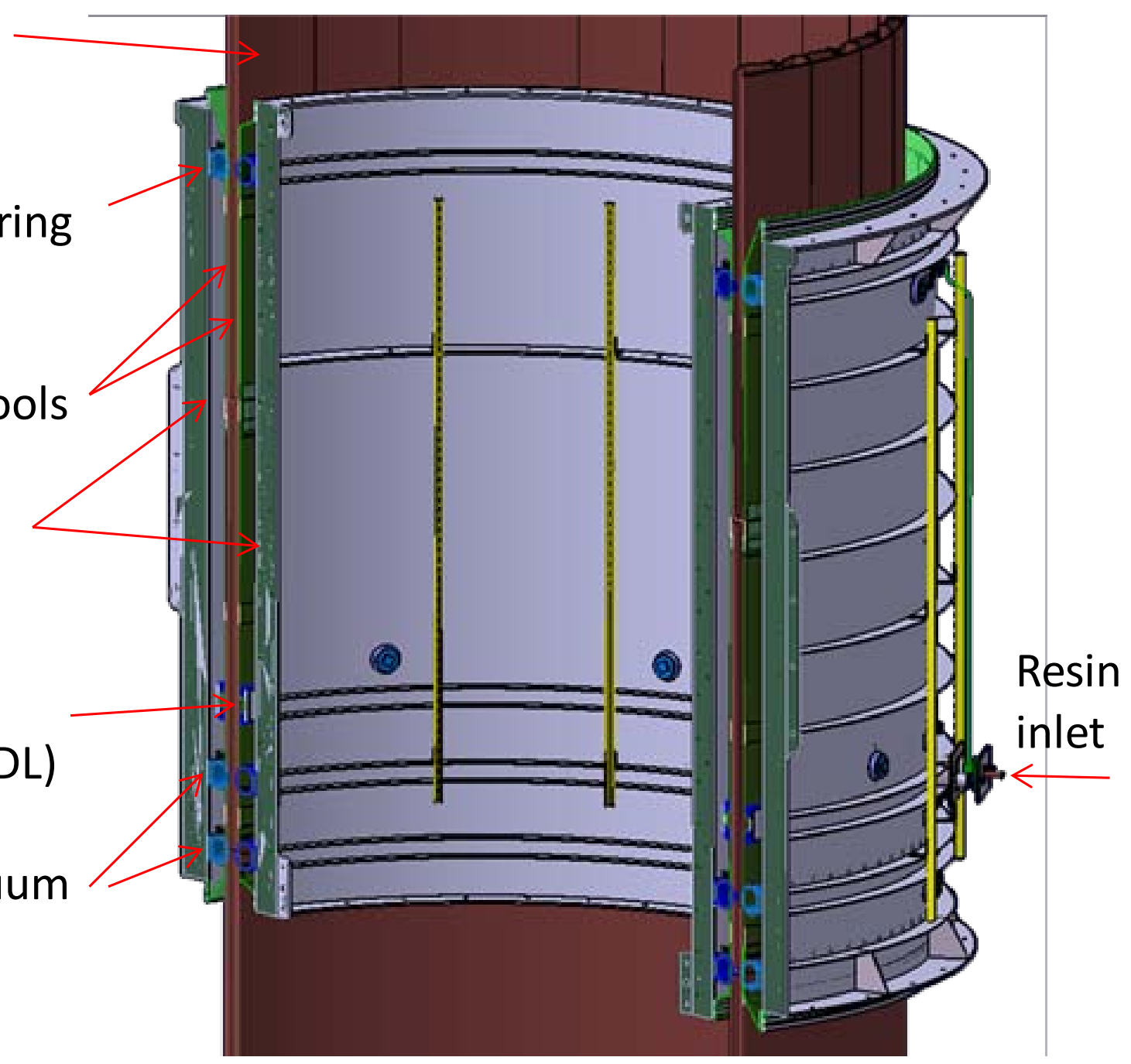


VI.C.1.a - Hard shells (outer and inner)
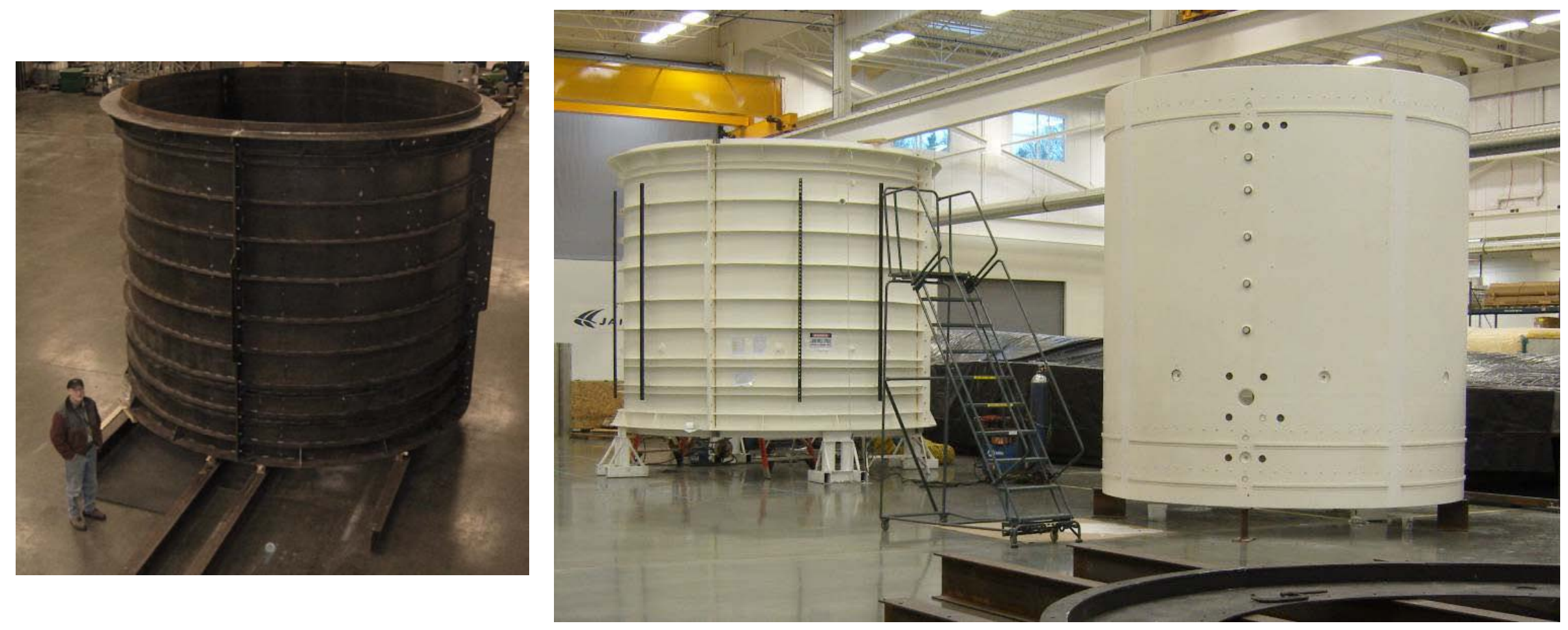


\section{VI.C.1.b - Soft tools including Re-Usable Resin Distribution Line (RURDL)}

- Achieving good sealing at the bottom of the apparatus

- Non-linear FEA was used to design key elements of the soft tools

- Re-usable Resin Distribution Line (RURDL)

- RURDL action

- Installing inner soft tool and RURDL around inner hard shell

- Photos of other elements of the Molding Region

- Durability of soft tool material 


\section{Achieving good sealing at the bottom of the apparatus}

\section{Approach:}

Mechanical ingredients that seat the soft tool firmly against the protruding cured end of the workpiece

\section{Results:}

-Robust sealing from the start

-Apparatus vacuum level rises to source vacuum level (to within gauge accuracy) without any corrective actions

-Excellent vacuum is the key to achieving a non-discernable knitline* during stepwise infusion

-No resin leakage whatsoever

*The knitline is the boundary between the resin cured in successive steps 

soft tools

Main bottom seals analysis is shown here

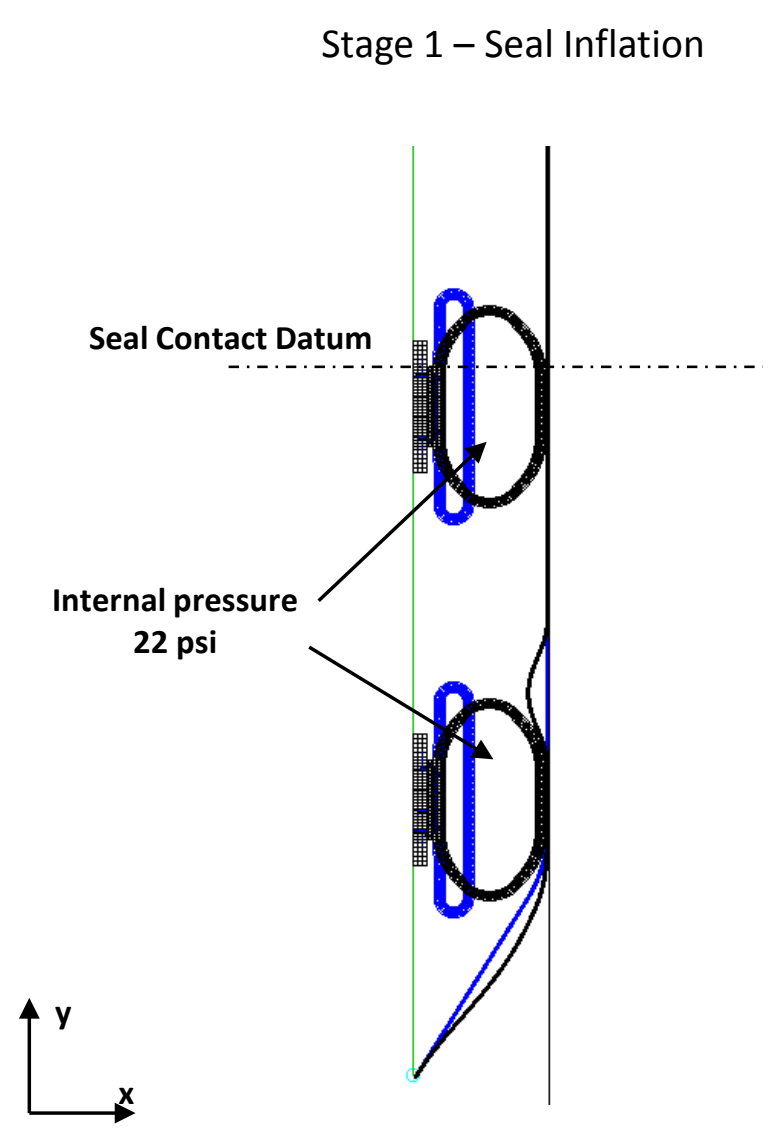

Stage 2 - Fluid Pressure

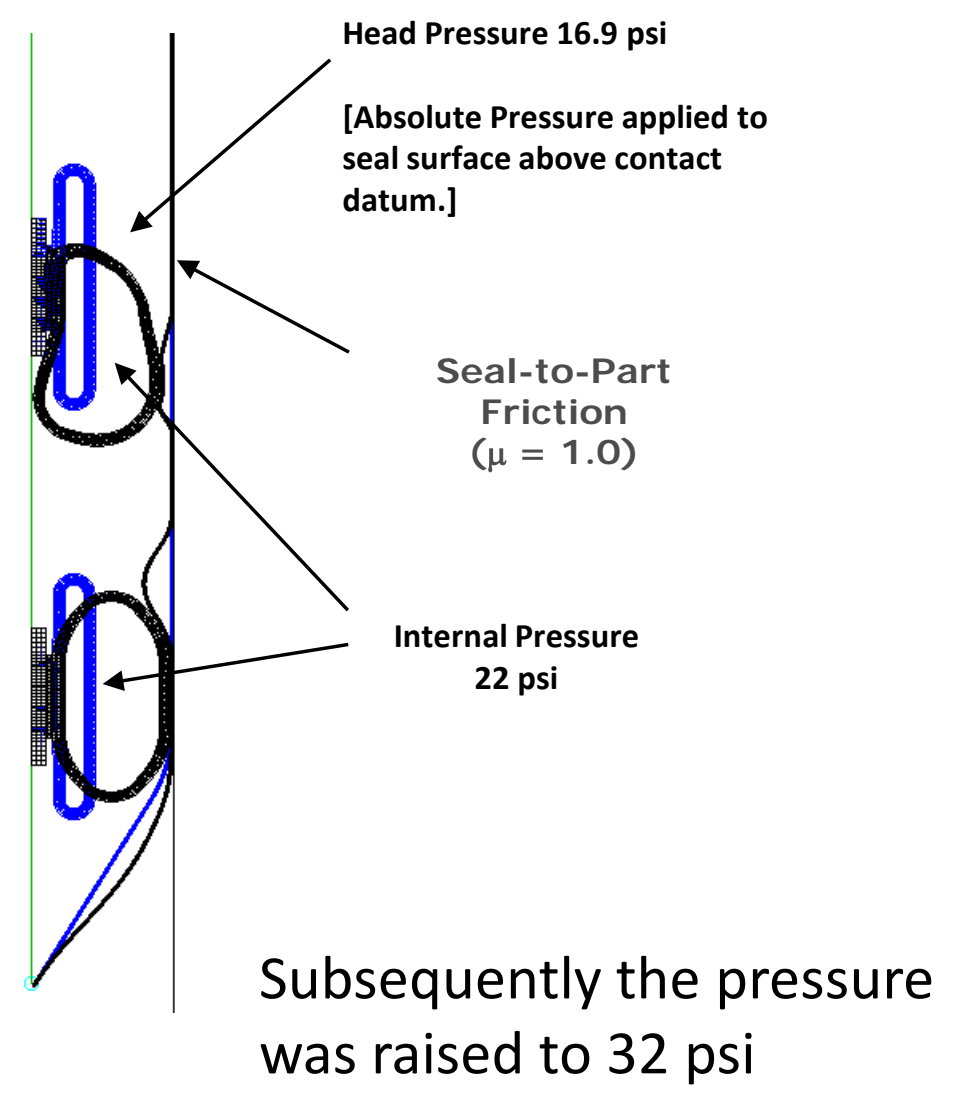

Janicki Industries subcontractor analysis 


\section{Re-usable Resin Distribution Line (RURDL)}

Inflate tubes during infusion

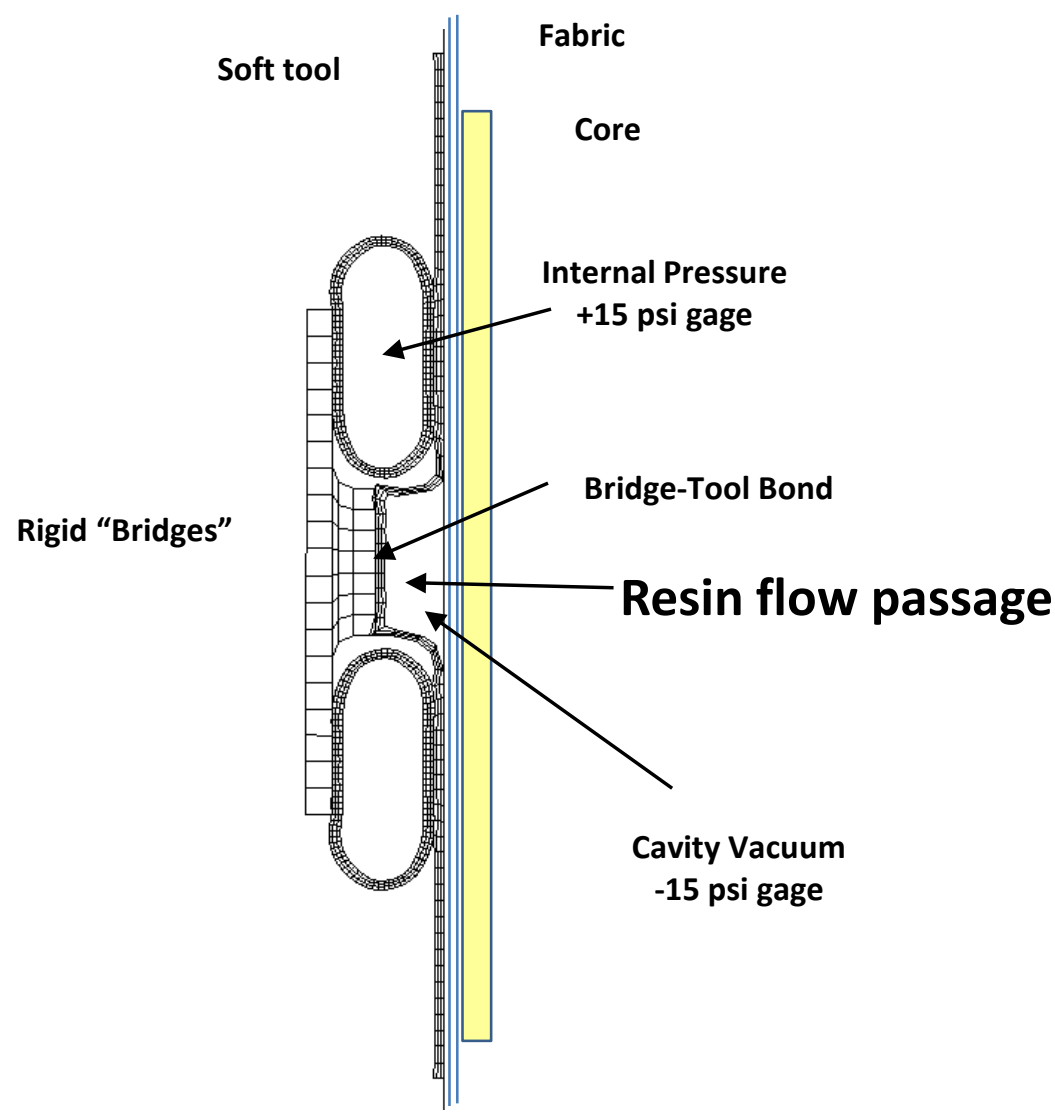

Collapse tubes during cure

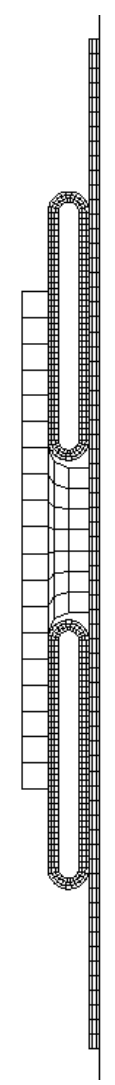

\section{Excess resin is} squeezed out of flow passage

Design of RURDL creates large passage for resin flow when air tubes are inflated, but passage collapses completely when air tubes are deflated 


\section{RURDL action}

Tubes inflated to $15 \mathrm{psi}$; RURDL

Tubes not inflated passage (on other side of black "bridges") opens up as planned

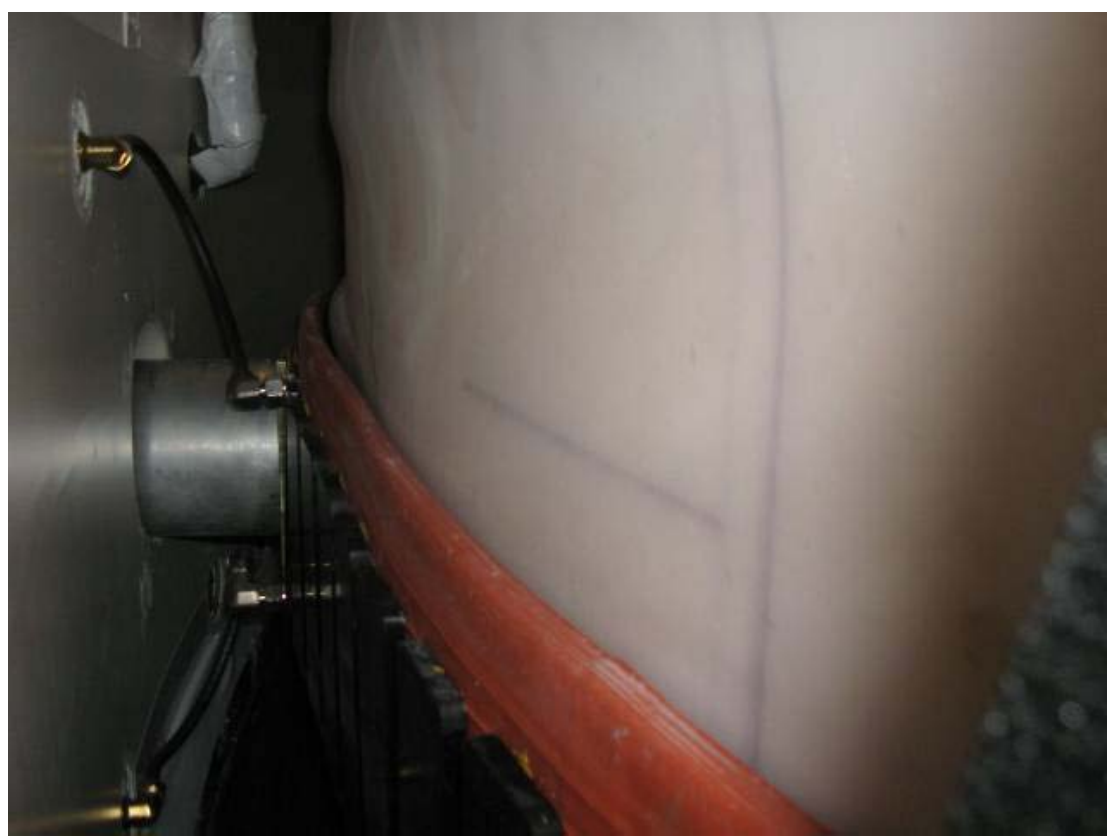



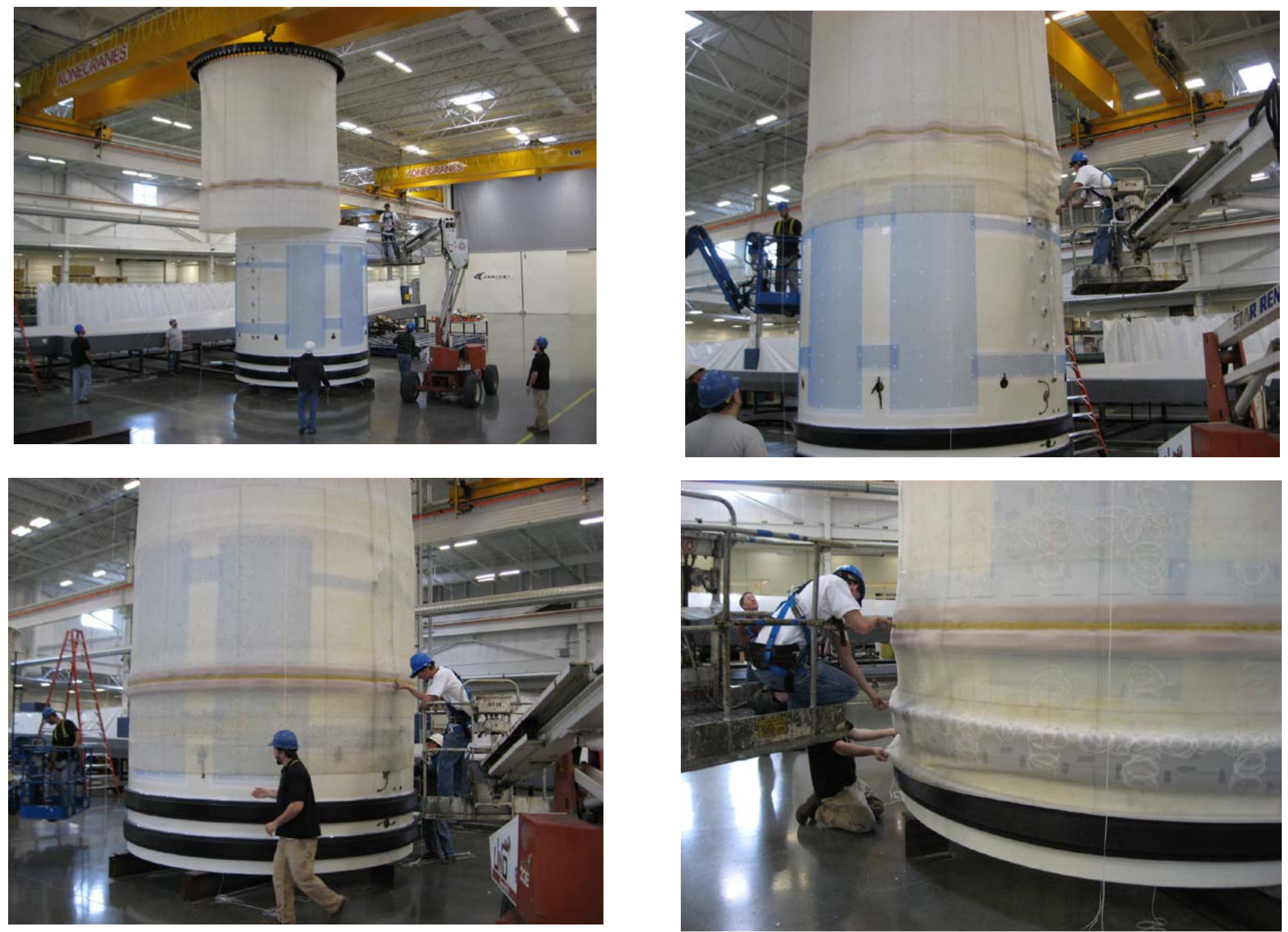

Janicki Industries photos 
Inflatable seals

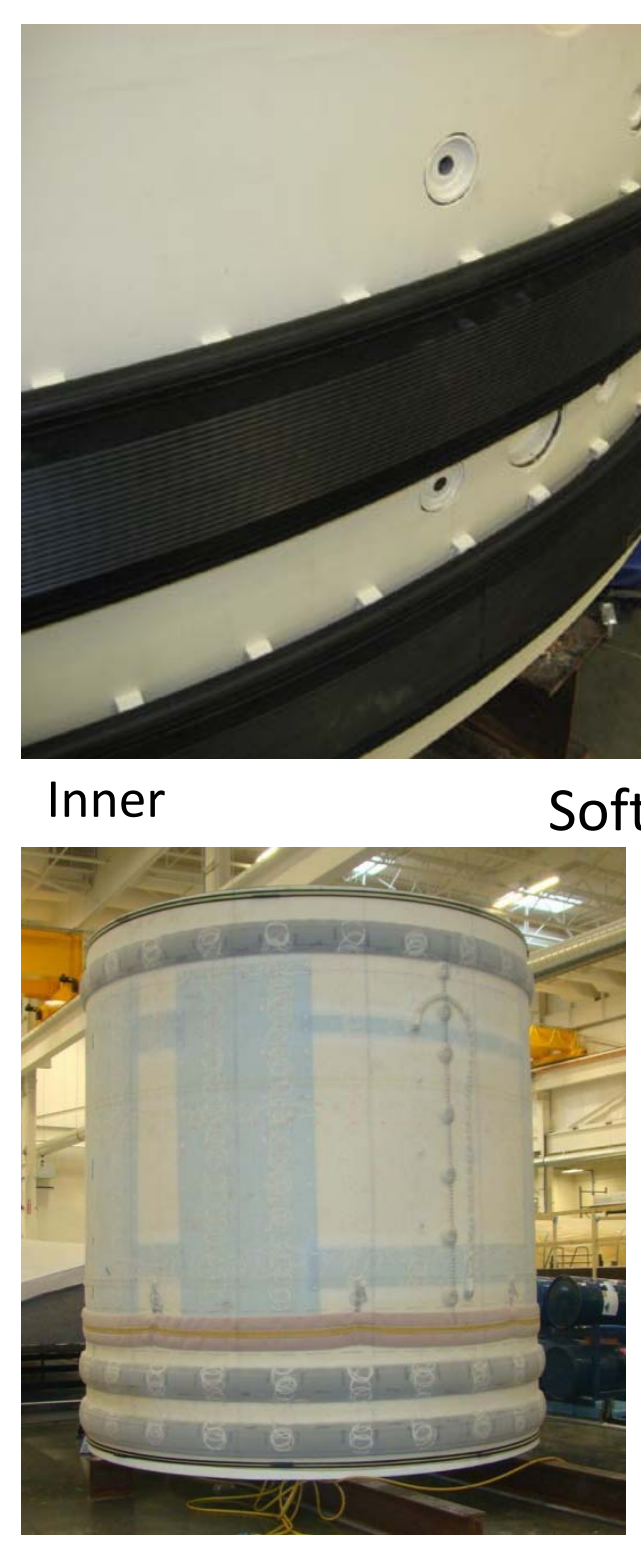

Flow front monitoring system LED lighting

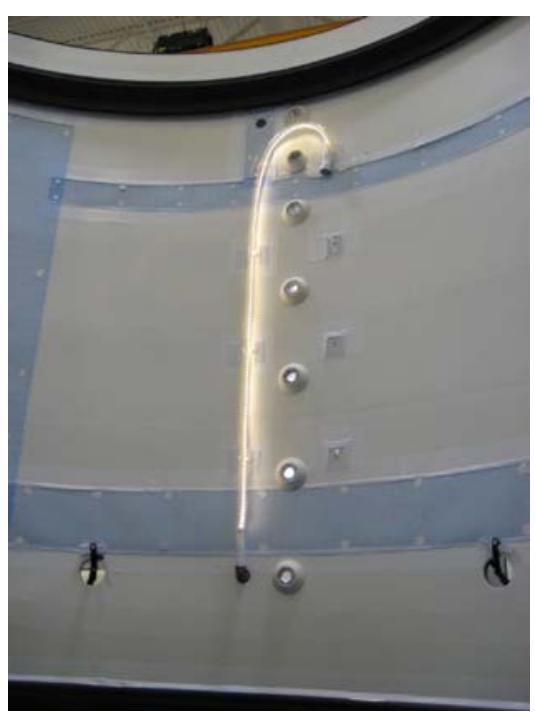

Outer video camera port

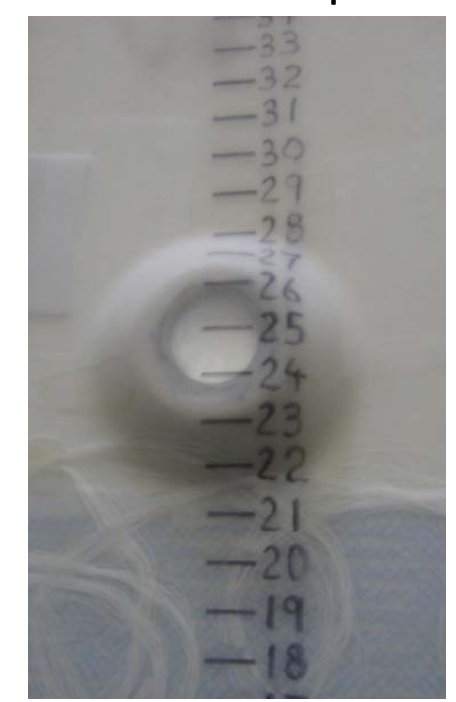

RURDL

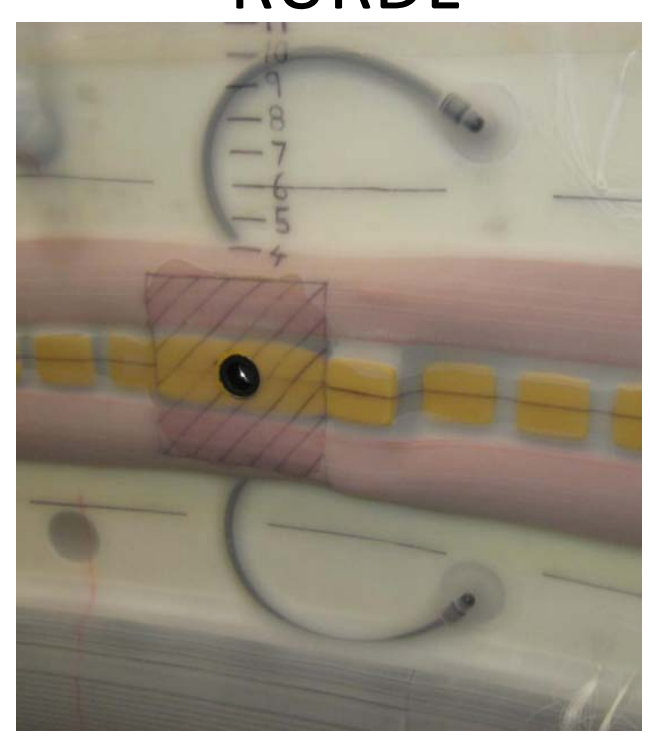

Janicki Industries photos 
"Flying" the soft tools prove-out test core (foam rings held together with fiberglass shear keys) into the Molding Region
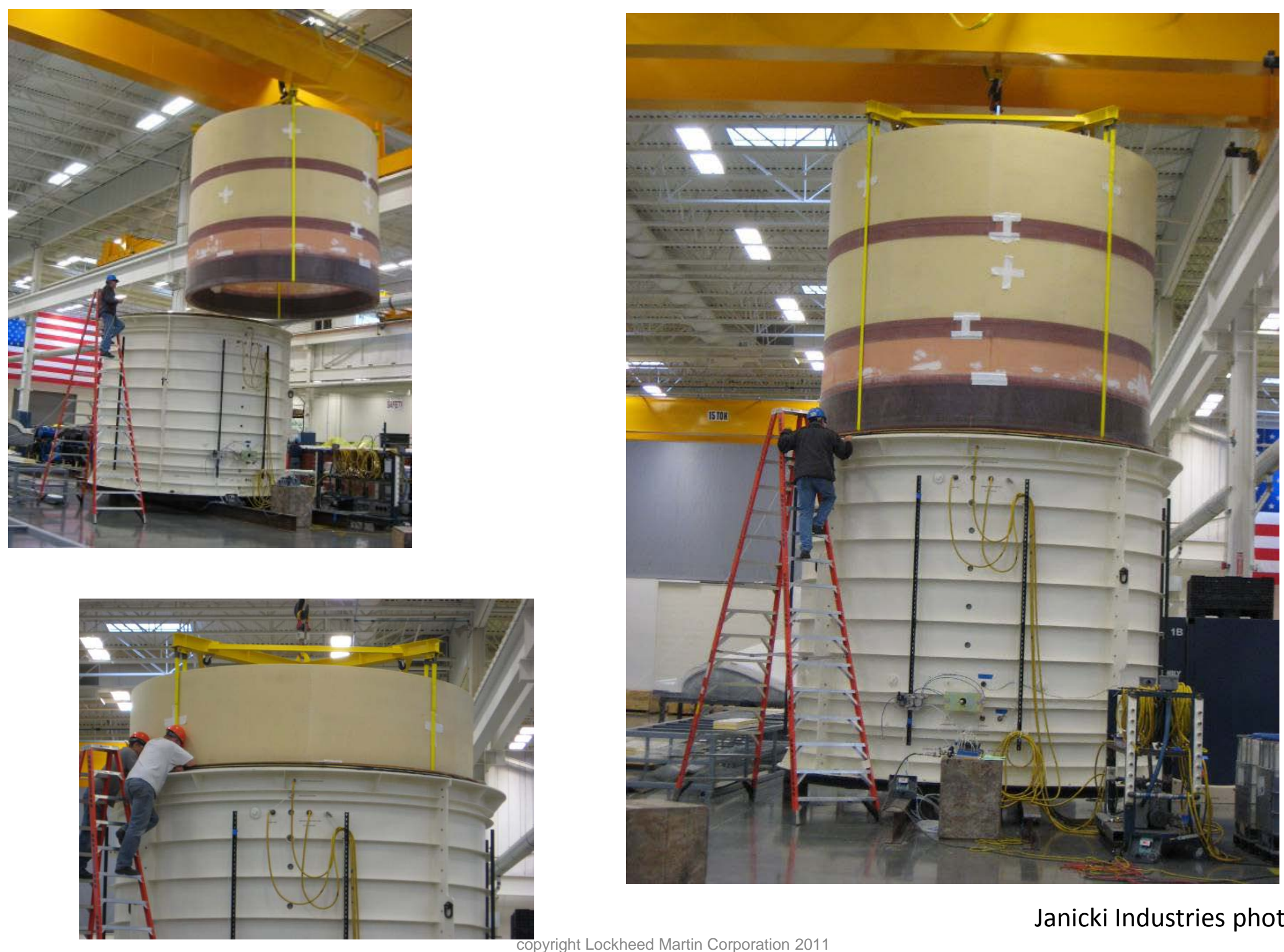

Janicki Industries photos 


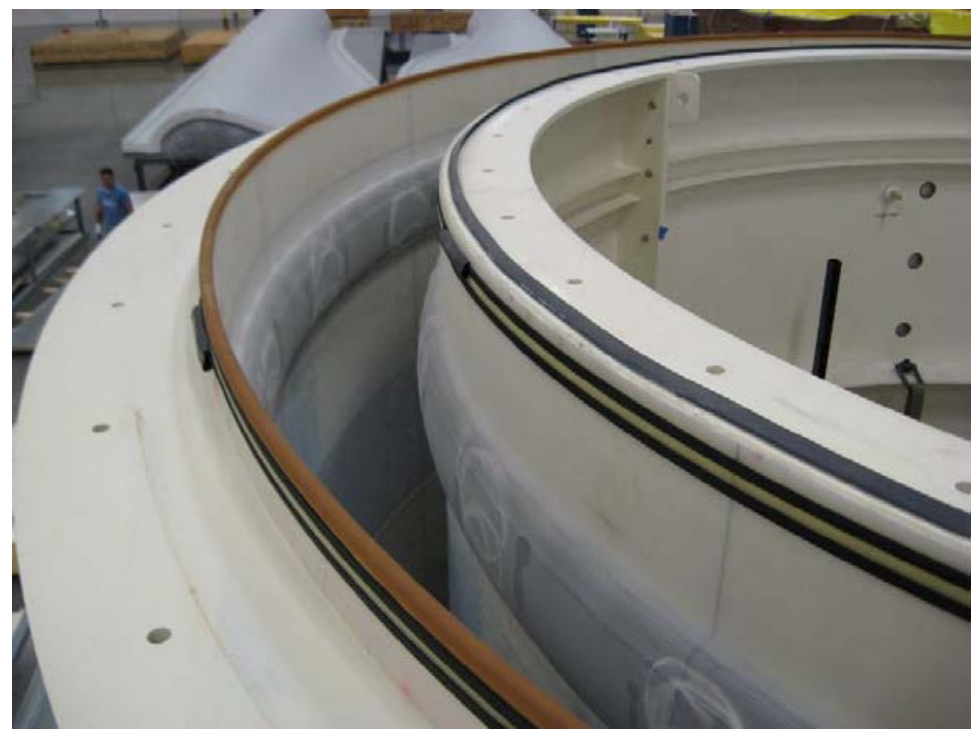

Top seals Pressurized lightly

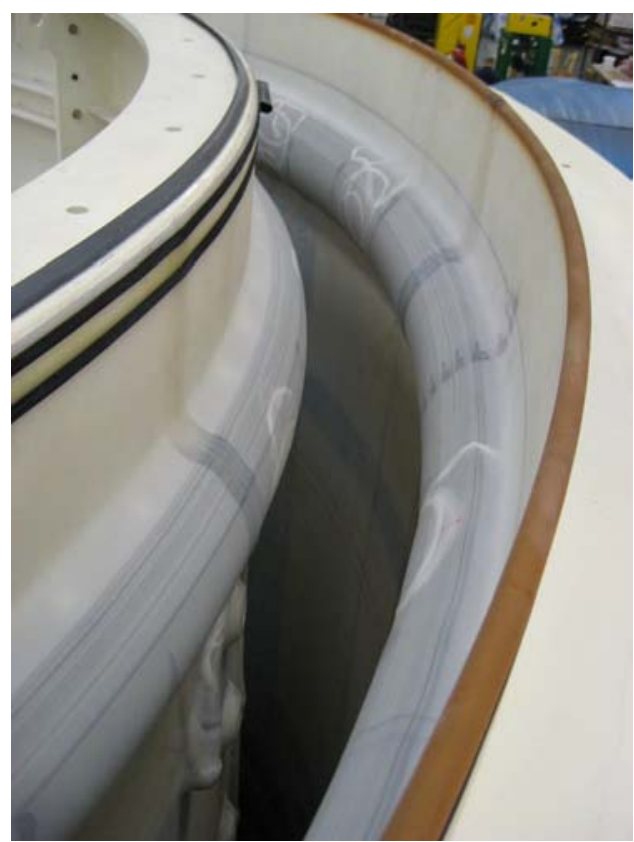

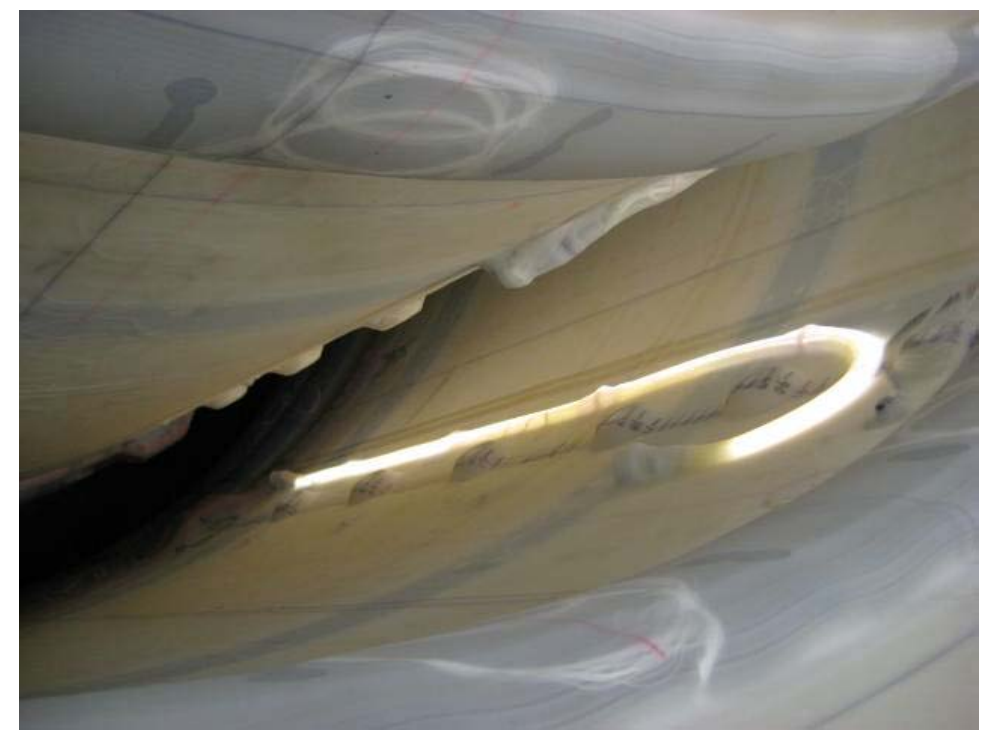

Top seals engaged with test core

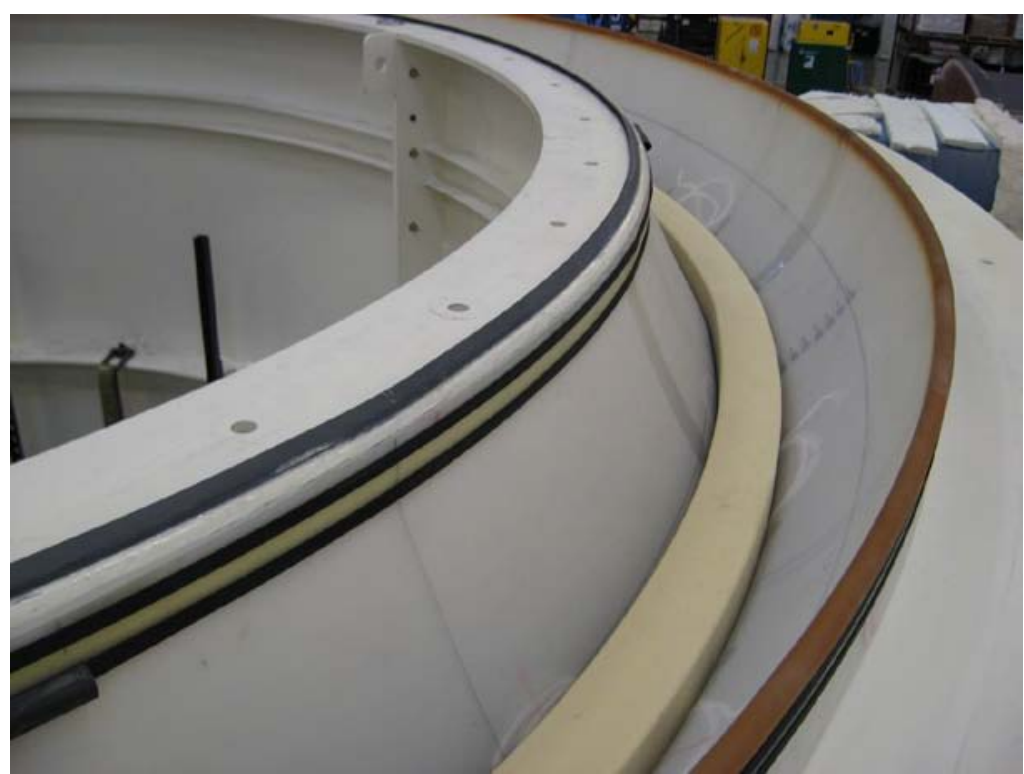




\section{Tests to evaluate durability of soft tool material}

\section{Purpose}

- The soft tools are re-usable vacuum bags against which the resin cures during each step of the fabrication process

- If the length per fabrication step is $39 \mathrm{ft}$. (current baseline), one Cold Water Pipe requires 80 steps

- Replacement of the soft tools during CWP fabrication is difficult

- Therefore tests were run in which samples of the soft tool material (silicone rubber) were repeatedly cured against laminates made with the Derakane 8084 vinyl ester resin of the CWP

- After each cure, the silicone rubber was peeled away from the cured laminate while the release force was measured.

- The purpose is to ascertain whether or not one set of soft tools is likely to survive for one CWP fabrication.

Various possible cure cycles were investigated

- Until seawater fatigue testing for various cure cycles is completed, it is not definite which of the following cure cycles typical for 8084 will be adequate:

1. Ambient-temperature cure only

2. Ambient-temperature cure + elevated-temperature $(175 \mathrm{~F})$ post-cure (most likely cycle)

3. Elevated-temperature only (220F)

- Accordingly, the repeated release behavior was evaluated for these three cure cycles.

- The 220F cure produced release forces much higher than the others, and was discontinued.

- Behavior for the other cure cycles is shown in the following two slides 


\section{Durability of soft tool material}

\section{-Perform repeated} layup/cure/release on samples of soft tool material

-Compare:

o Room temperature (RT) cure + 175F postcure

vs.

ORT cure only

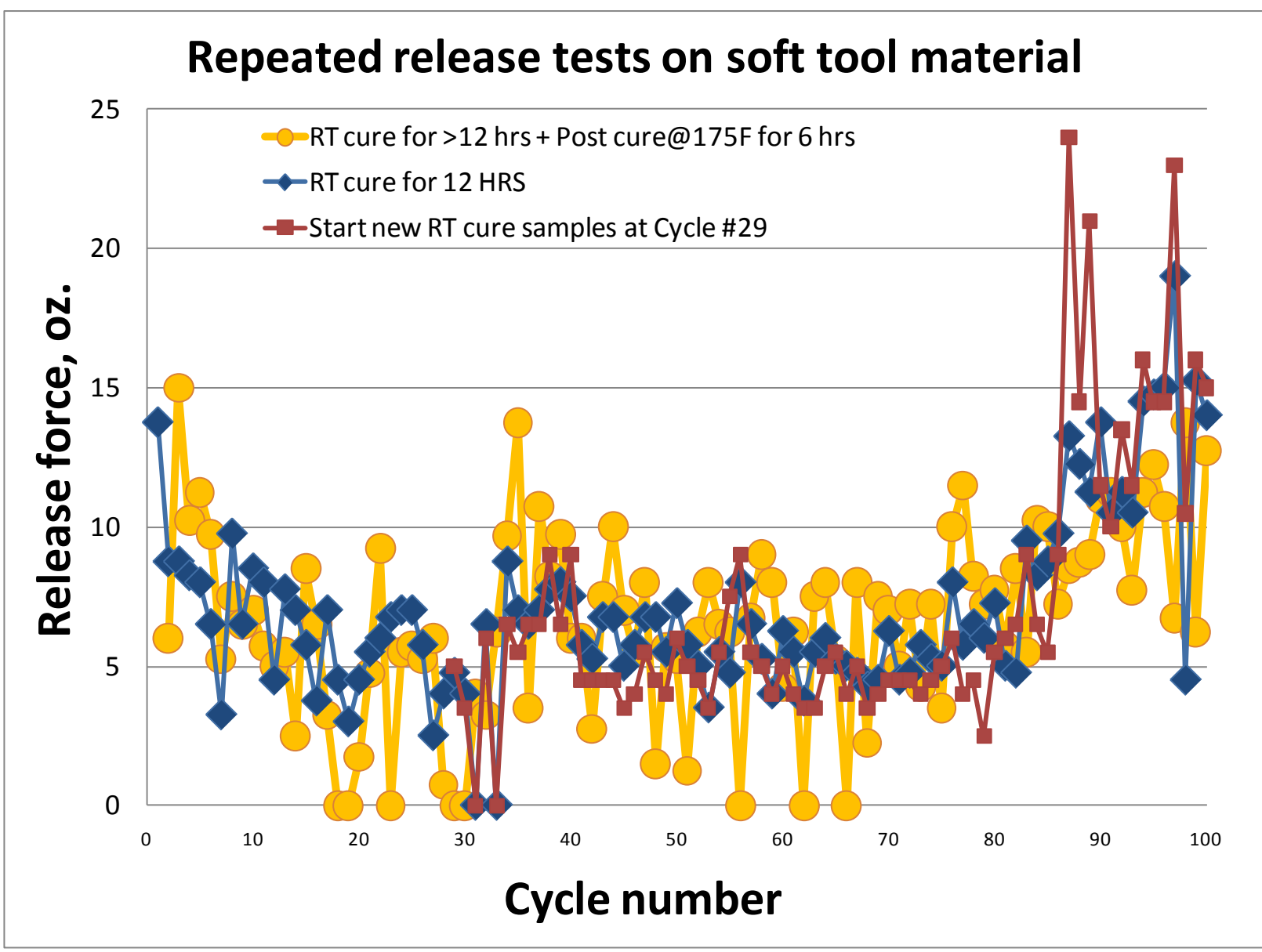

-After 100 cycles, release forces in baseline samples are no higher than at the start - See next slide for interpretation of anomalous upswing in release forces over last 15 cycles -Maximum release force with RT cure $+175 \mathrm{~F}$ post-cure is very similar to RT cure only - Conclusion: We can use RT cure $+175 F$ post cure for on-the-water CWP fabrication with no detrimental effect on soft tool life compared to RT cure only 


\section{Anomalous behavior seen during last 15 cycles}
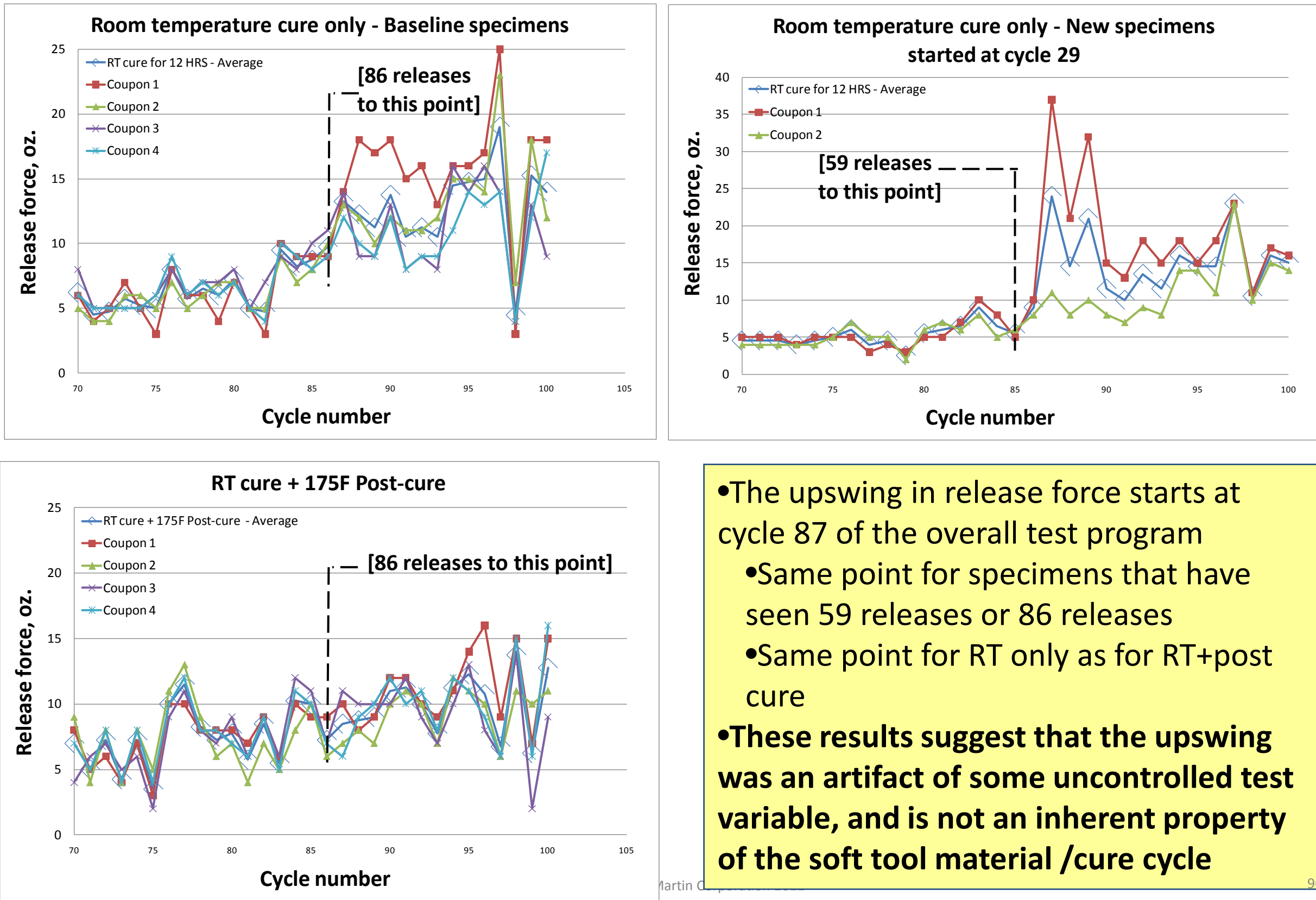

-The upswing in release force starts at cycle 87 of the overall test program

-Same point for specimens that have seen 59 releases or 86 releases -Same point for RT only as for RT+post cure

-These results suggest that the upswing was an artifact of some uncontrolled test variable, and is not an inherent property of the soft tool material /cure cycle 


\section{VI.C.1.C - Resin and resin handling elements}

- Resin system

- Resin Inlet Line (RIL) and actuators

- Resin mixing system

- Catalyzed resin supply system

- Catalyzed resin reservoir 


\section{Resin system}

DERAKANE 8084 Epoxy Vinyl Ester Resin

January, 2006

High Elongation Tough Epoxy Vinyl Ester Resin

Typical Liquid Resin Properties
DERAKANE 8084 epoxy vinyl ester resin is an elastomer modified resin designed to offer increased adhesive strength, superior resistance to abrasion and severe mechanical stress, while giving greater toughness and elongation. DERAKANE 8084 and DERAKANE 8090 resins are the only vinyl esters available that offer this exceptional combination of properties.

\begin{tabular}{|c|c|}
\hline Property ${ }^{(1)}$ & Value \\
\hline Density, $25^{\circ} \mathrm{C} / 77^{\circ} \mathrm{F}$ & $1.02 \mathrm{~g} / \mathrm{mL}$ \\
\hline Dynamic Viscosity, $25^{\circ} \mathrm{C} / 77^{\circ} \mathrm{F}$ & $360 \mathrm{mPa} \cdot \mathrm{s}$ \\
\hline Kinematic Viscosity & $350 \mathrm{cSt}$ \\
\hline Styrene Content & $40 \%$ \\
\hline Shelf Life ${ }^{(2)}$, Dark, $25^{\circ} \mathrm{C} / 77^{\circ} \mathrm{F}$ & 6 months \\
\hline
\end{tabular}




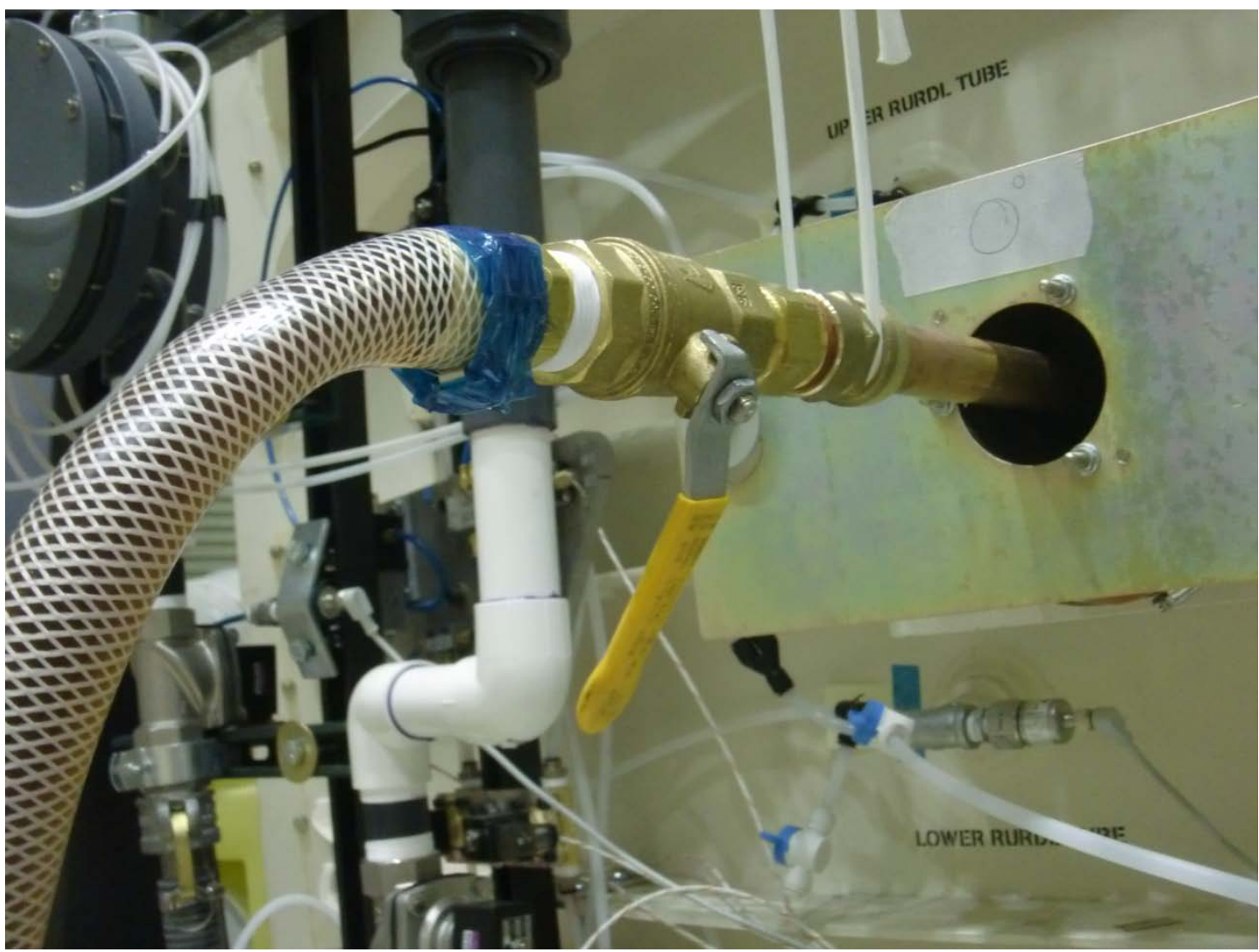

-The only non-reusable element is the RIL itself

-Inexpensive leak-tight fittings and mechanical valves are used

-Shape of the fitting at the end of the RIL causes it to break off at the workpiece.

-Air cylinders press end of RIL against workpiece during cure, to ensure no stub is left. 


\section{OIE}

Resin mixing system
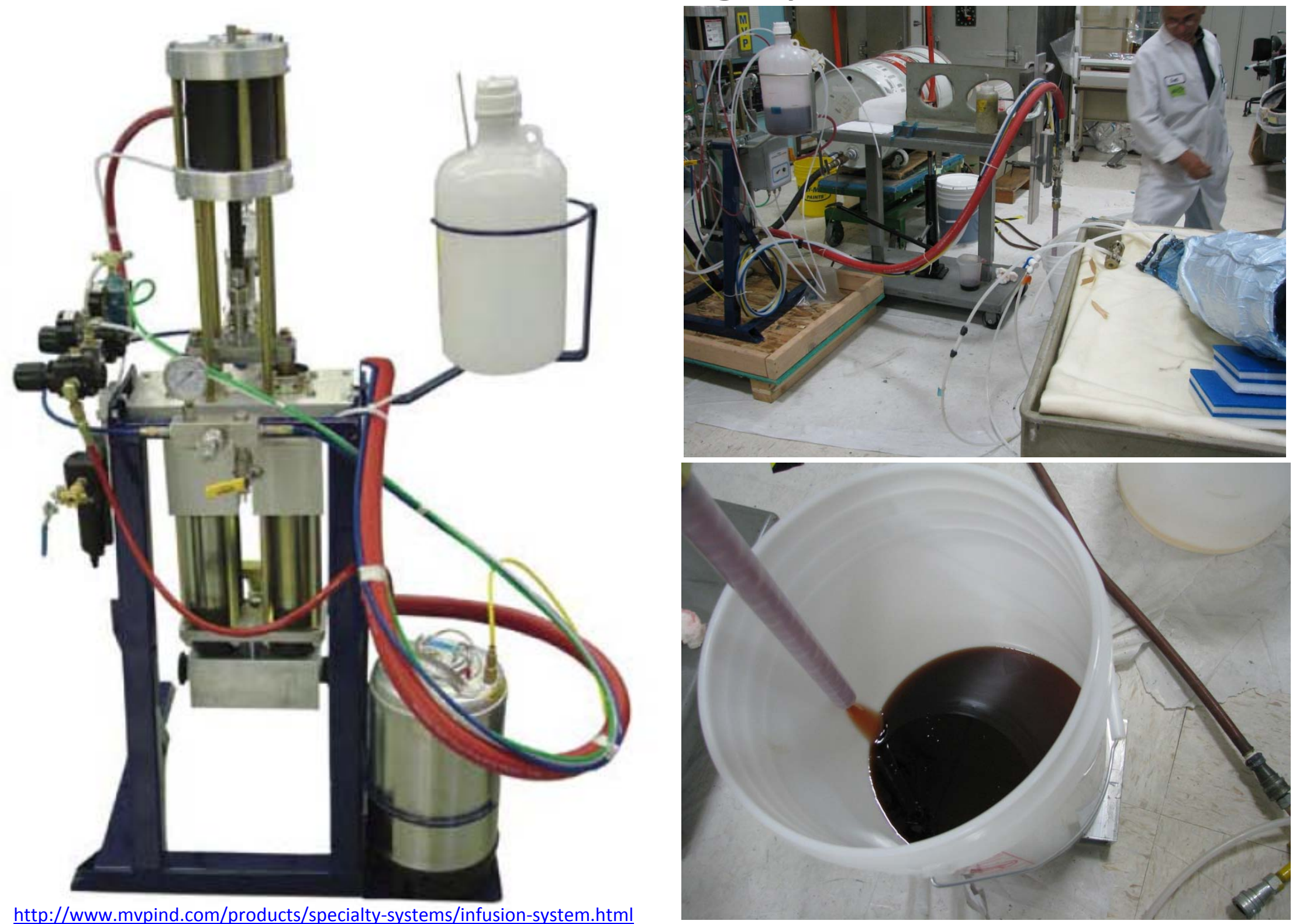
During infusion

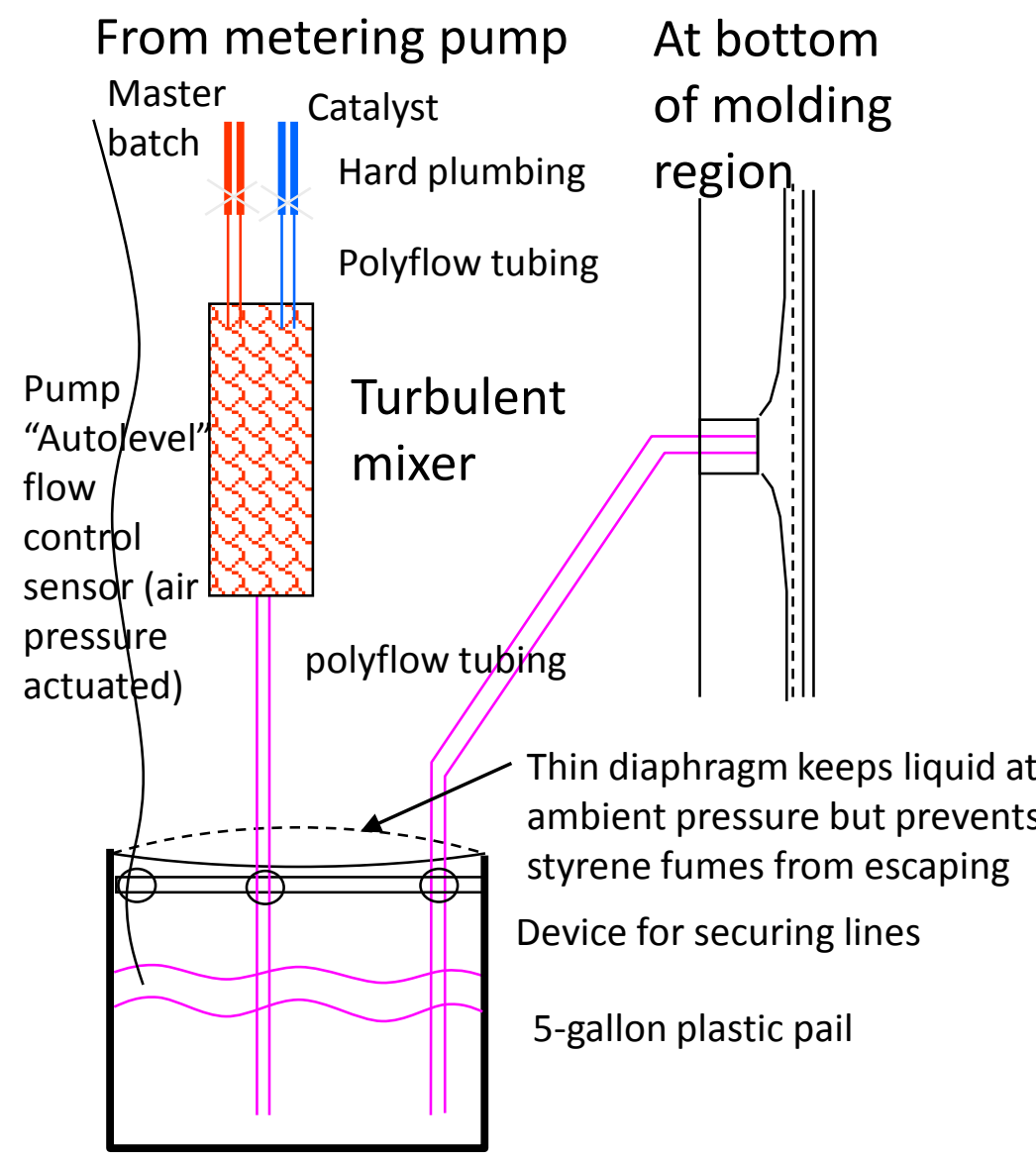

On lower platform

\section{During cure}

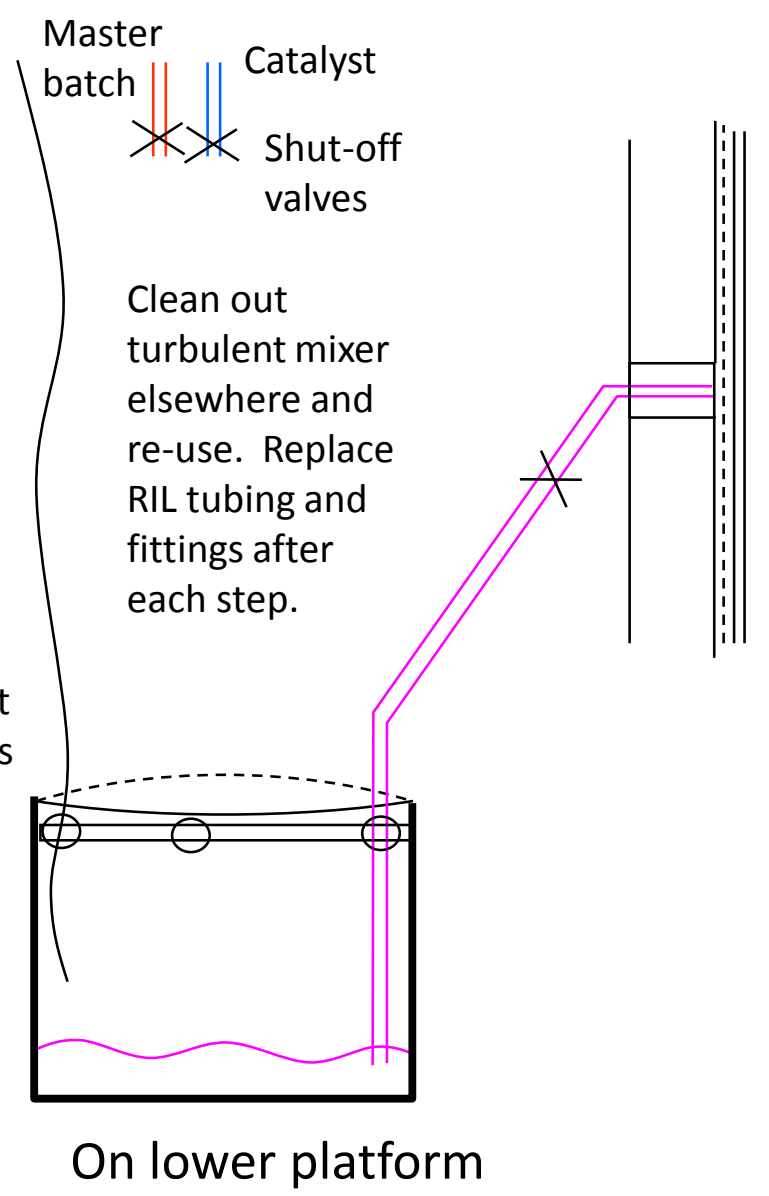

Design of resin supply system allows huge workpiece to be filled quickly without requiring large batches of catalyzed resin that might be prone to exotherm. About 1000 lbs. of resin was mixed and infused in 3 shots, with no problems. 


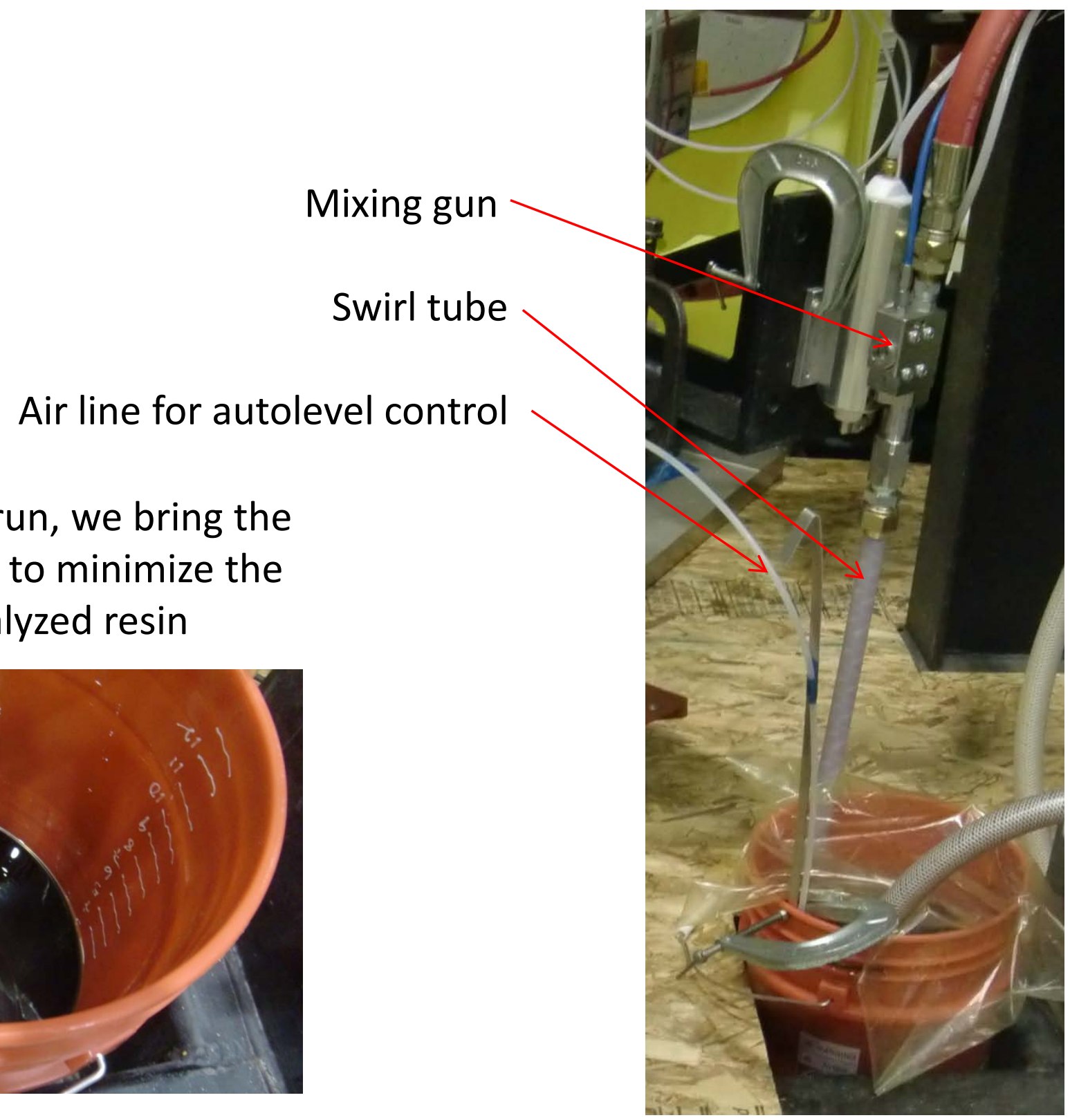

At the end of the run, we bring the liquid level down to minimize the leftover catalyzed resin

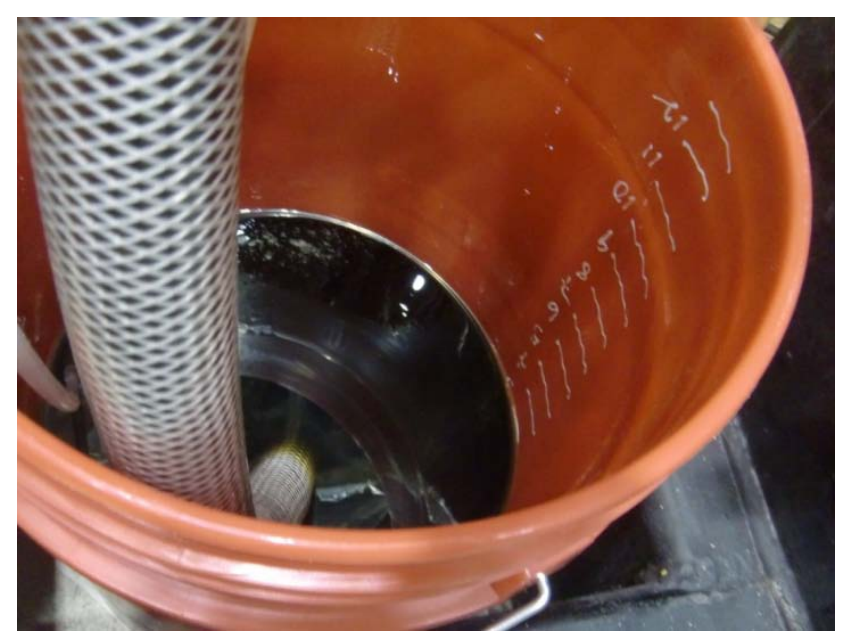




\section{VI.C.1.d - Acceptance testing at} Janicki, transport to Sunnyvale,

\section{and installation in B/132 High Bay}

- Molding Region during acceptance test at Janicki Industries

- Molding region arrives in Sunnyvale for installation in B/132

- Getting a 16'5" wide part through a 16' wide rollup door

- "Lab supports" for inner and outer molding regions

- Installing outer lab supports

- Lifting inner mold back into outer mold

- Installing inner lab supports 
Molding Region during acceptance test at Janicki Industries (8-11-2010)

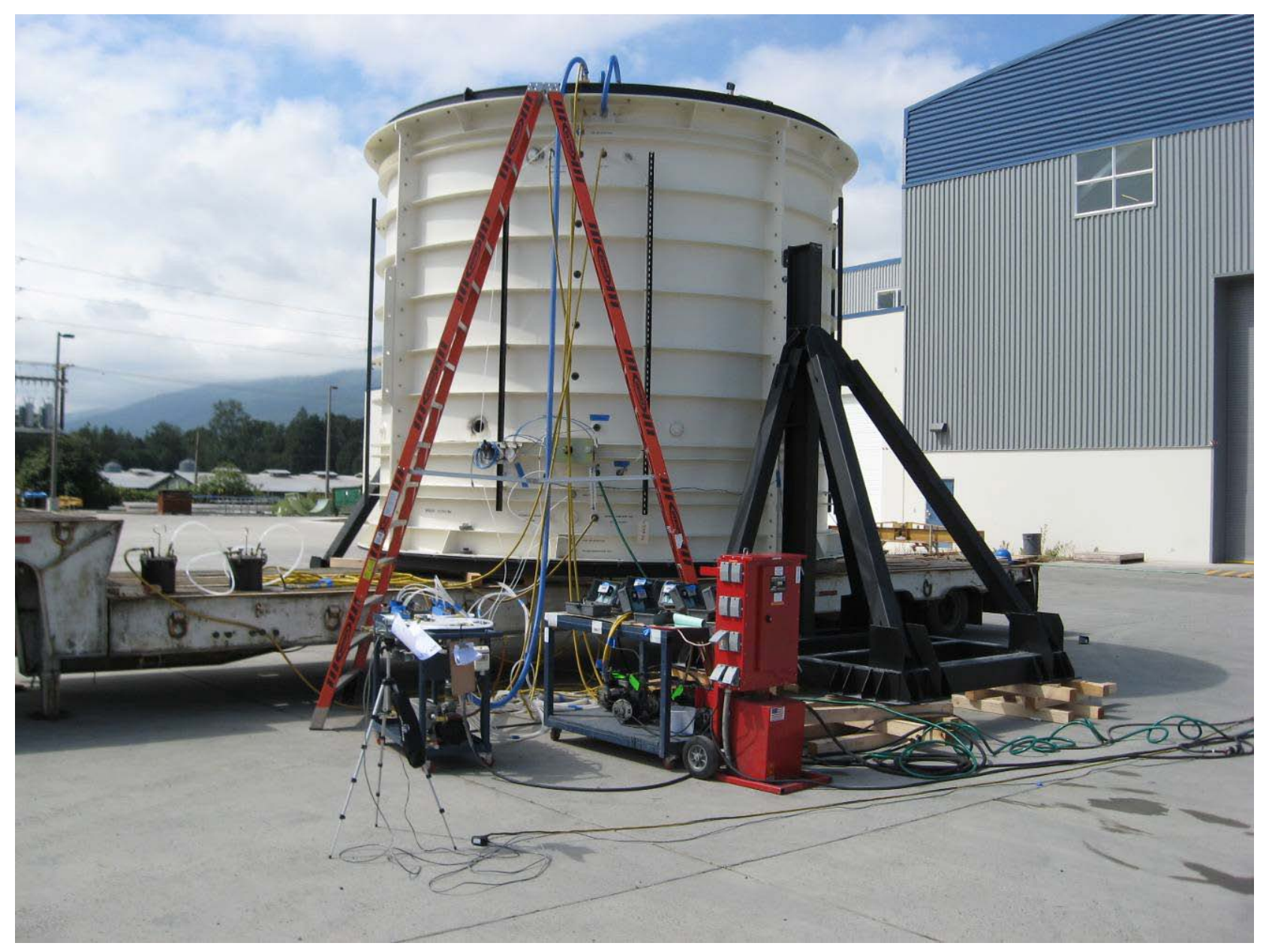

Final half of test was conducted outside to avoid possible damage to other work in Janicki's Hamilton facility just in case any water leaked out. It didn't.

OMR lab supports were used to help stabilize the molding region on the bed of the low boy truck. 

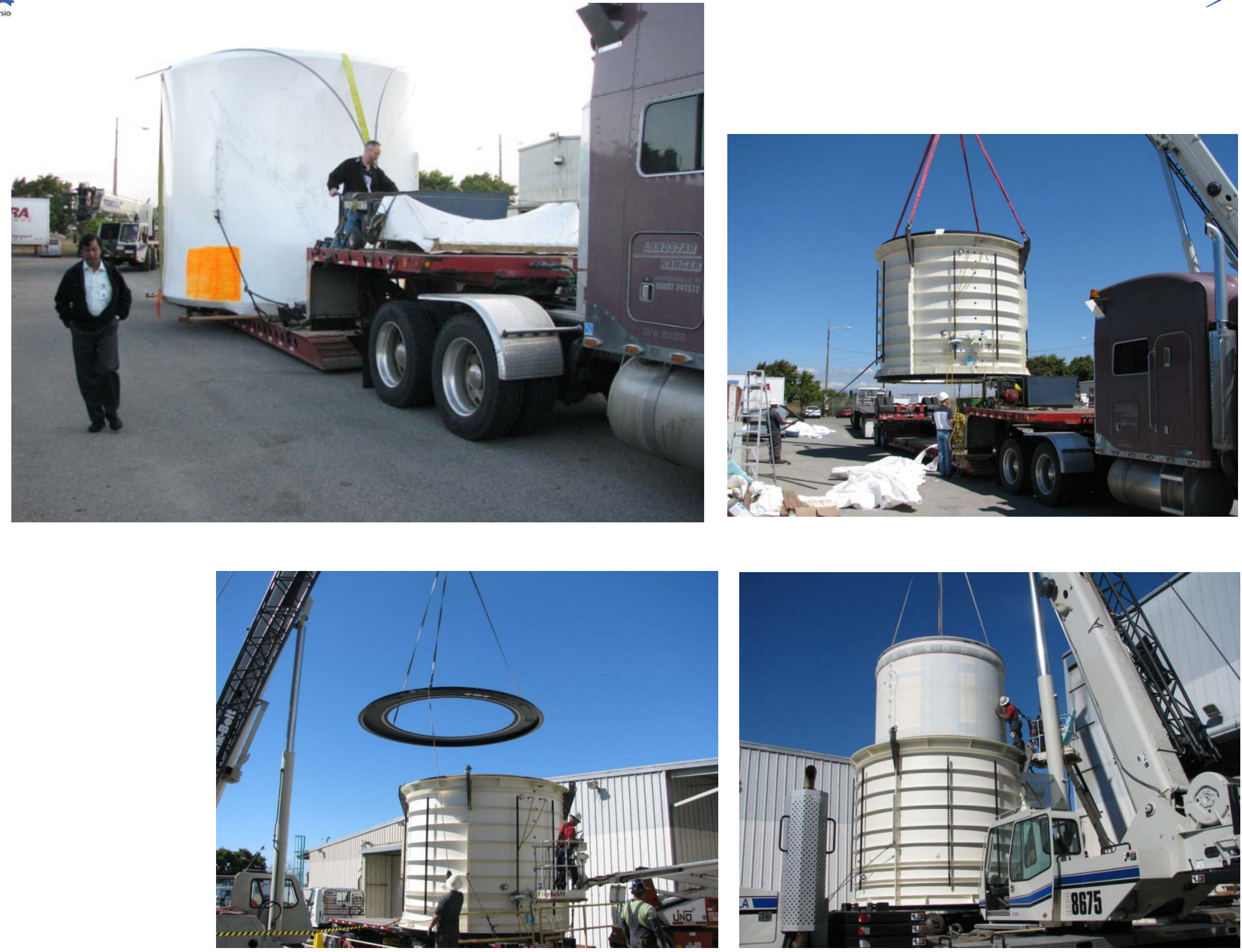

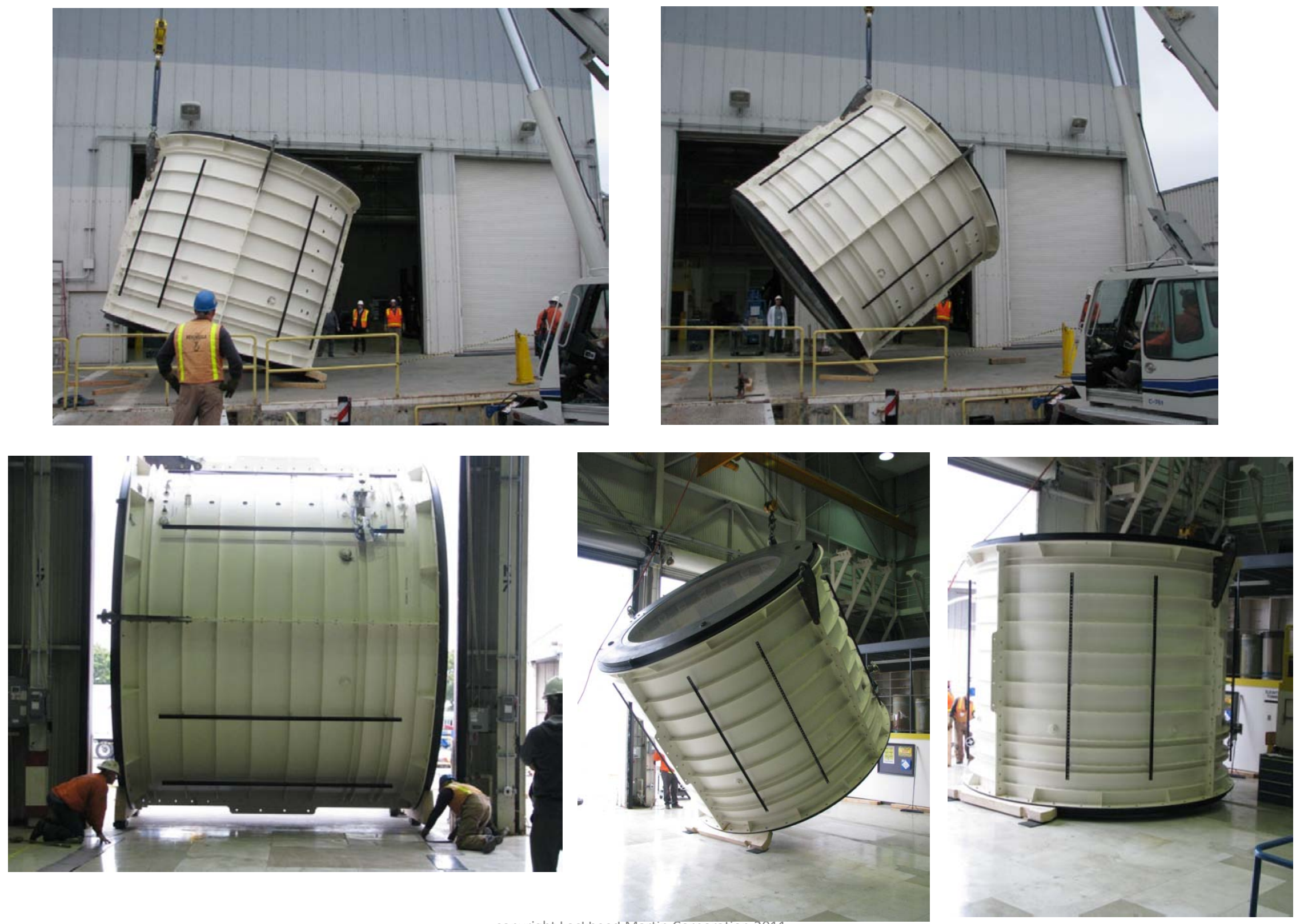


\section{OJEc}

"Lab supports" for inner

and outer molding

regions
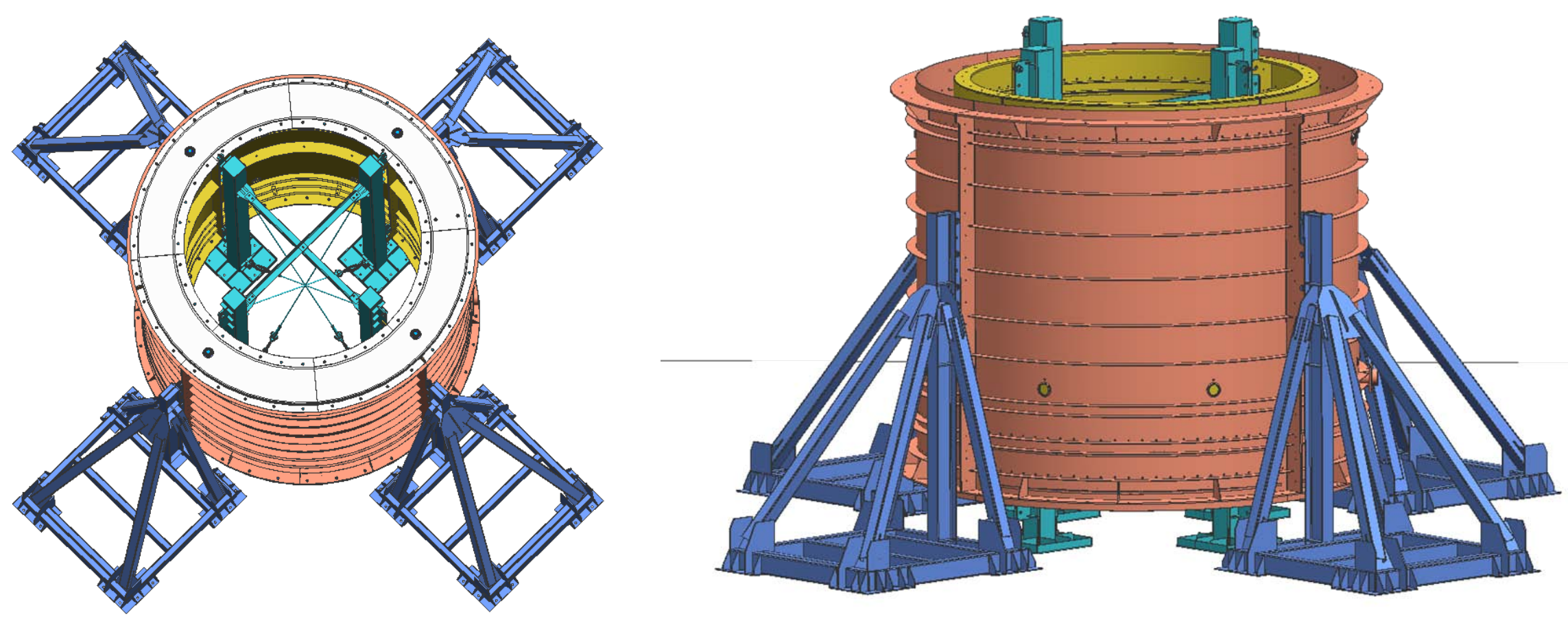

Janicki Industries graphic 


\section{OJEc}

Installing outer lab supports
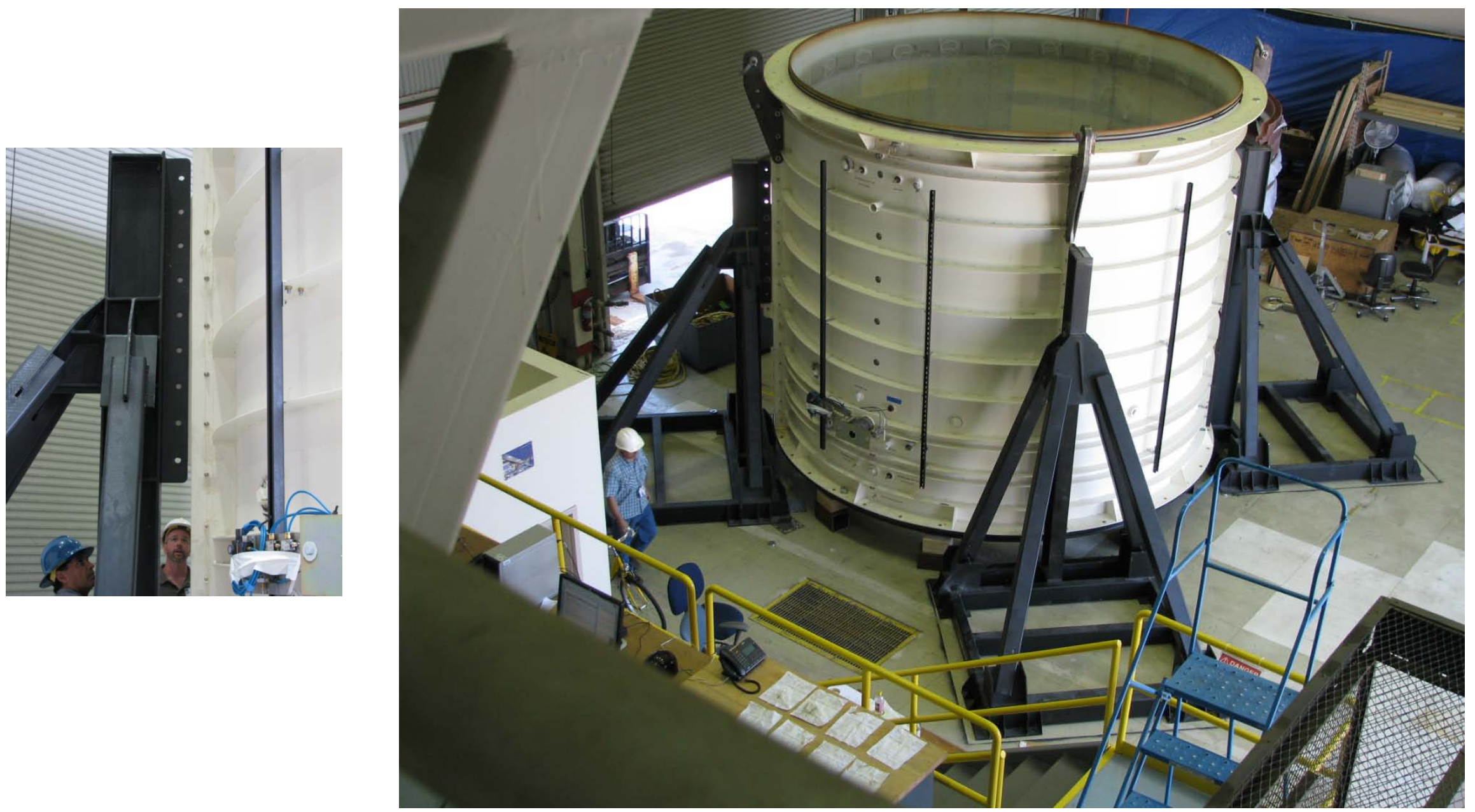


\section{OJEC}

Lifting inner mold back into outer mold
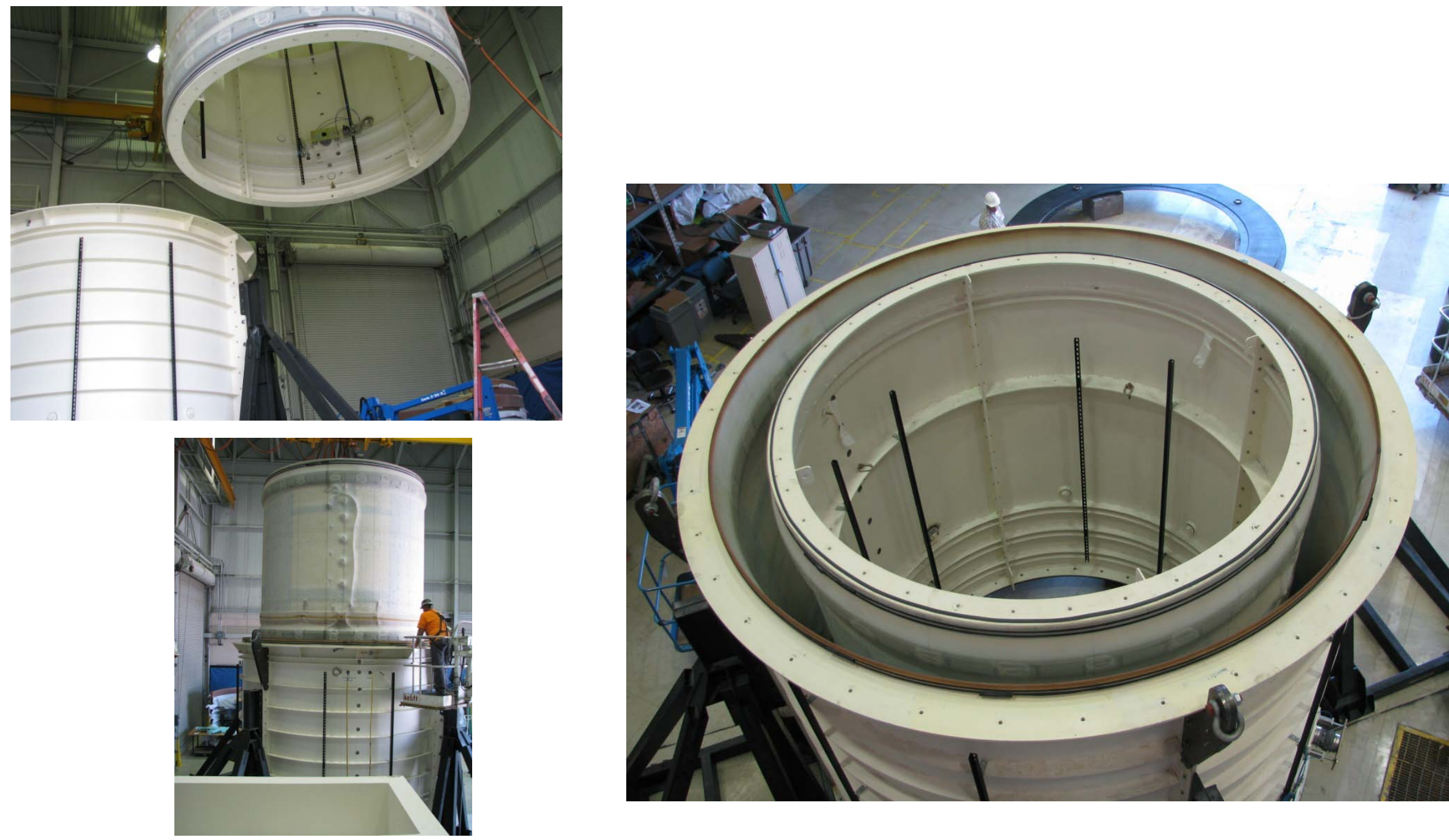


\section{OIEC \\ Installing inner lab supports}
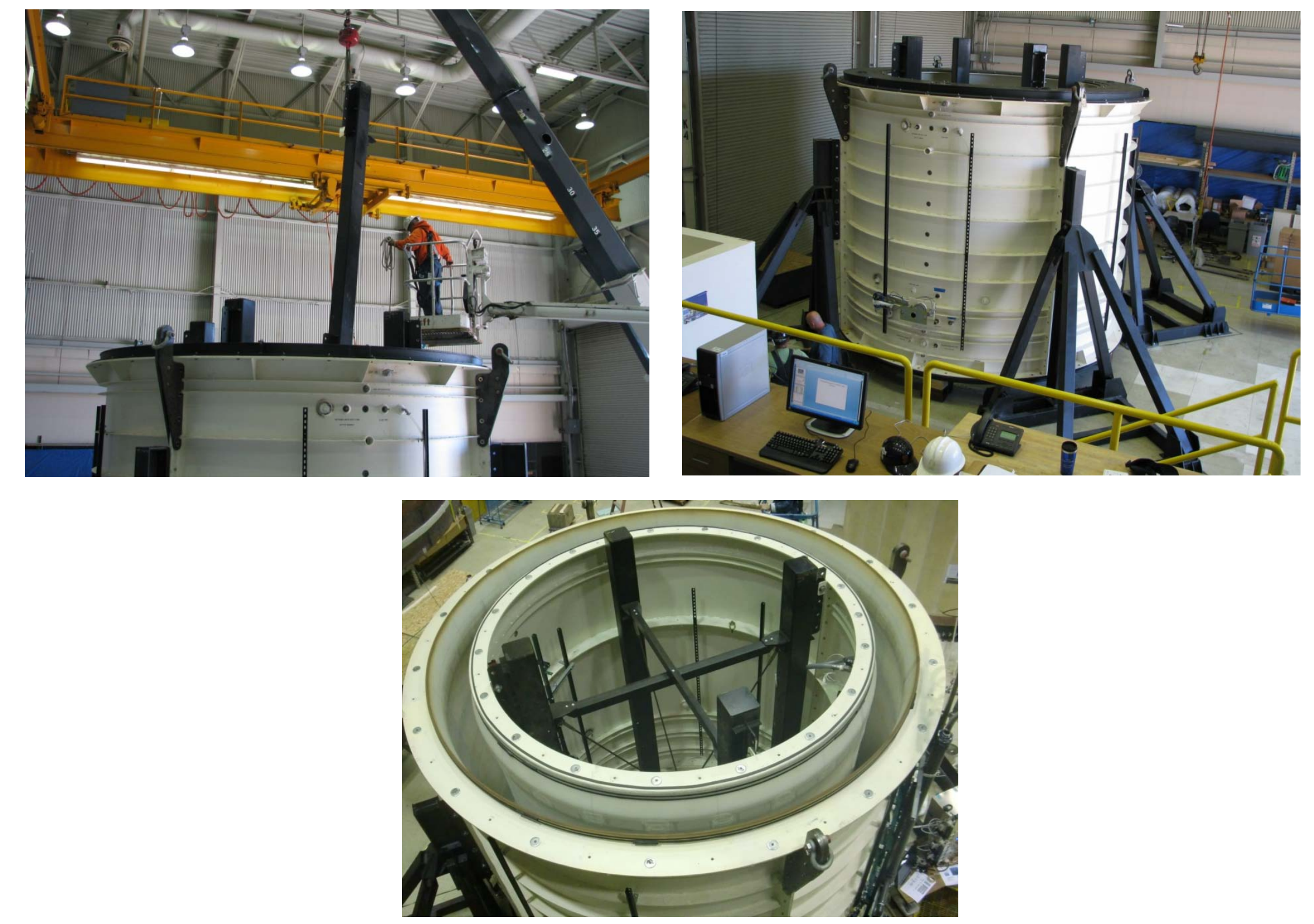


\section{VI.C.1.e - Molding region control system}

- Control system approach for current program

- Control system components

- Resin flow-front height visual sensing system

- Installation of control system elements

- Control system - Installed 


\section{Control system approach for current program}

- Control all principal subsystems from a centralized location using clear, easyto-follow step-by-step settings

- Install and use actuators and sensors that will become part of the full integrated CWP fabrication apparatus in the future

- Control these actuators manually by simple and inexpensive toggle switches mounted in a panel. Read out the sensors by simple and inexpensive analog voltmeters.

- Provide step-by-step instructions for operation of the control system by a computer next to the control panel

- The graphical and macro-based features of this Excel program were written by Matt Ascari

- Use the same computer for logging in of data, results, and comments during the runs

The alternative would have been a full computer control system for the Molding Region, and this was judged to be out-of-scope and not needed for the current program, in which flexibility was preferred over automation.

When the Molding Region is combined with the Fabric Dispensing System, we may expand the latter's computer control system to also cover the molding operations 
Control system components

Solenoid valves

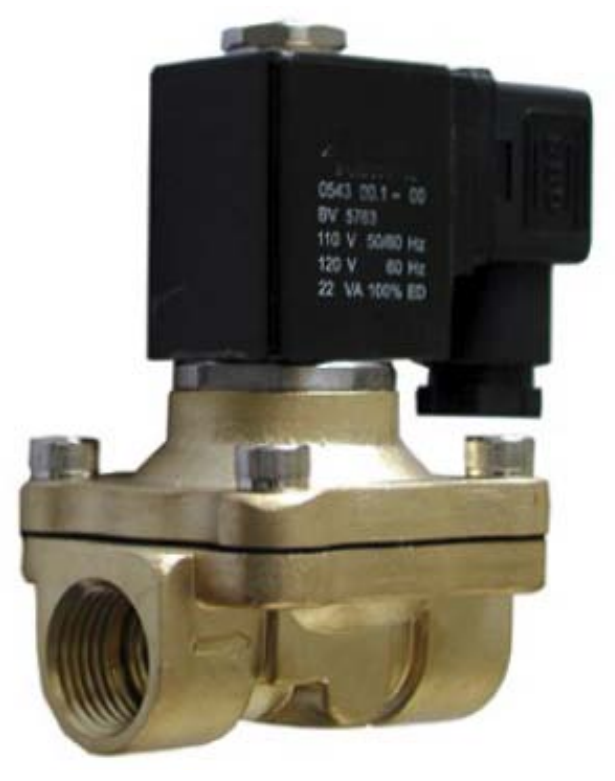

Panel meters

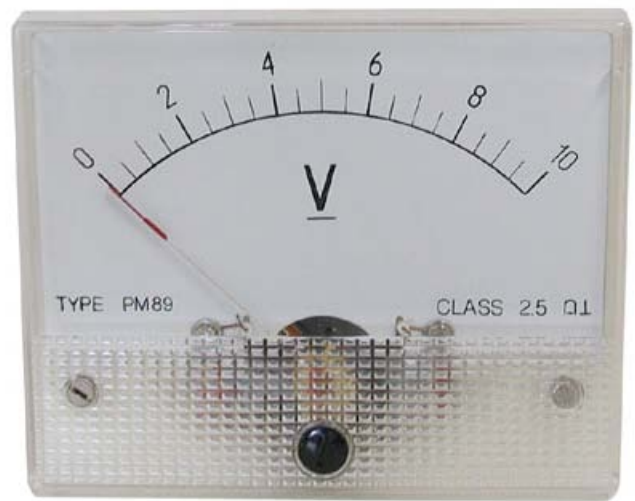

Vacuum regulators

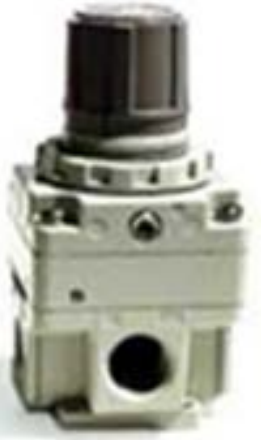

$1 / 2^{\prime \prime}$

NPT

Air pressure regulators

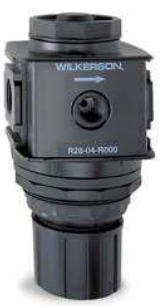

Toggle switches

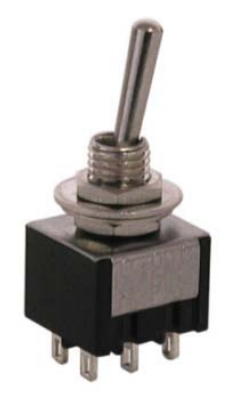

2"

NPT
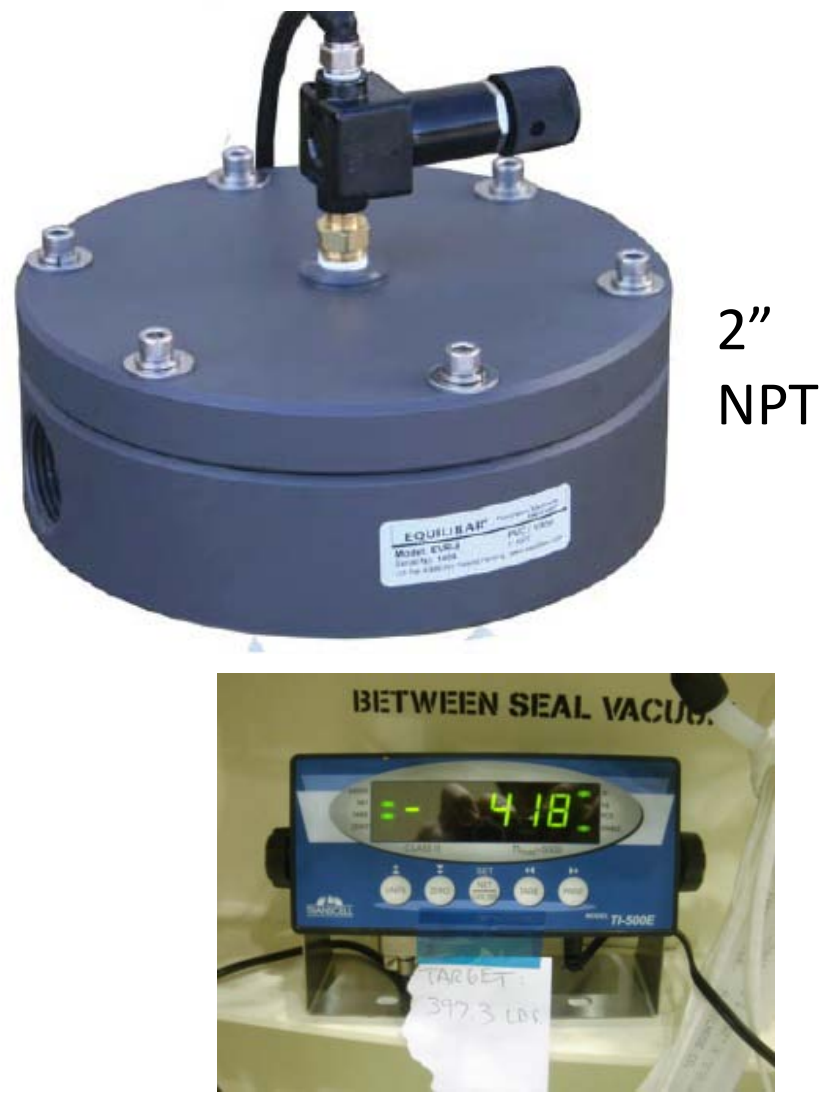

Platform scale 


\section{OJEC \\ Resin flow-front height visual}

sensing system

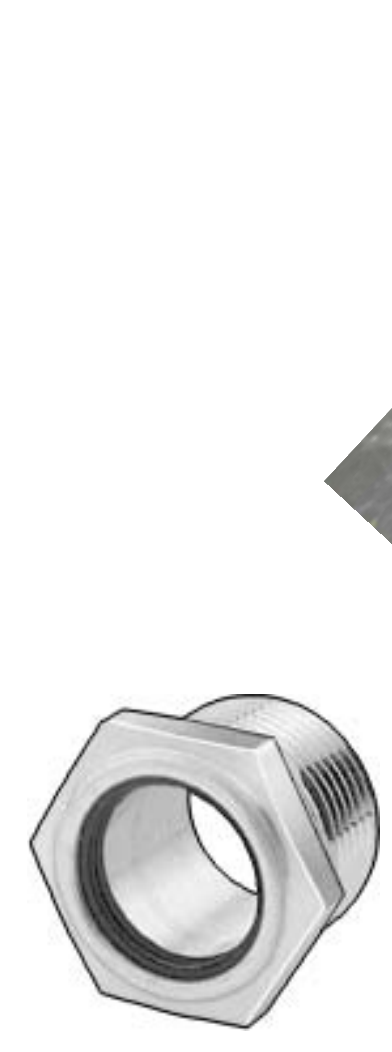

Sight glasses built into hard shells of molding region

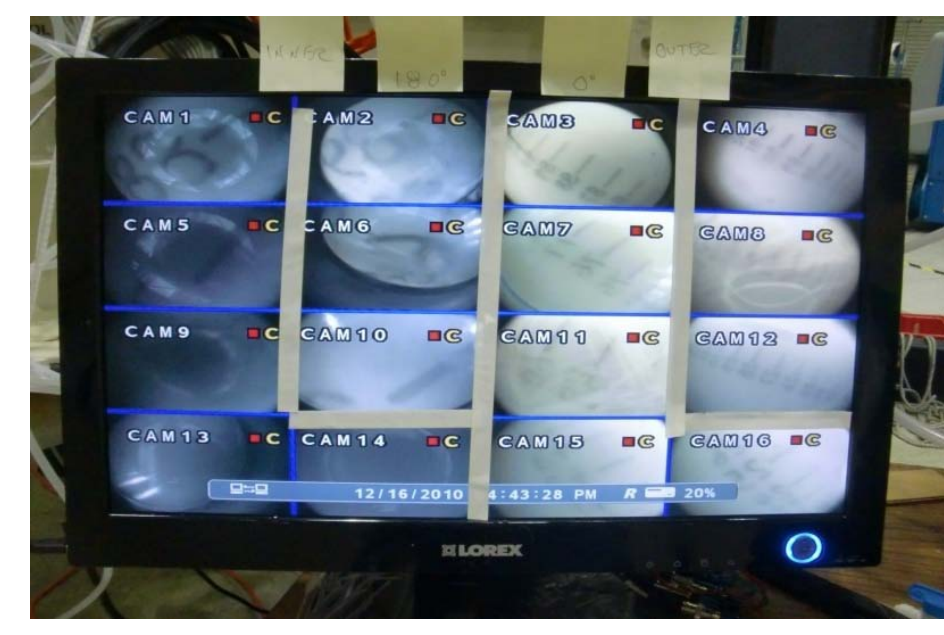

16-channel video display and recorder 


\section{OJEC \\ Installation of control system elements}
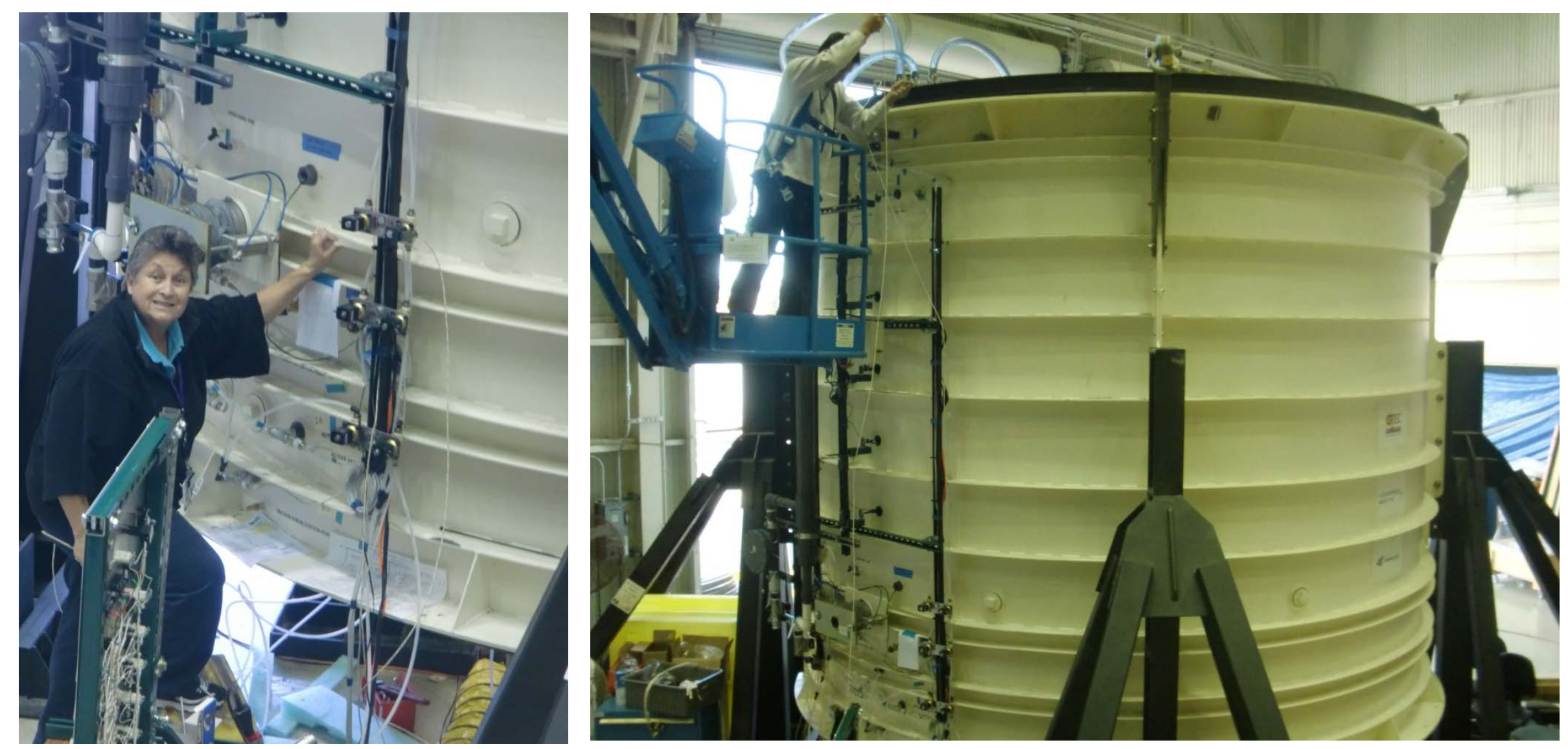


\section{Control system - Installed}

OJEC
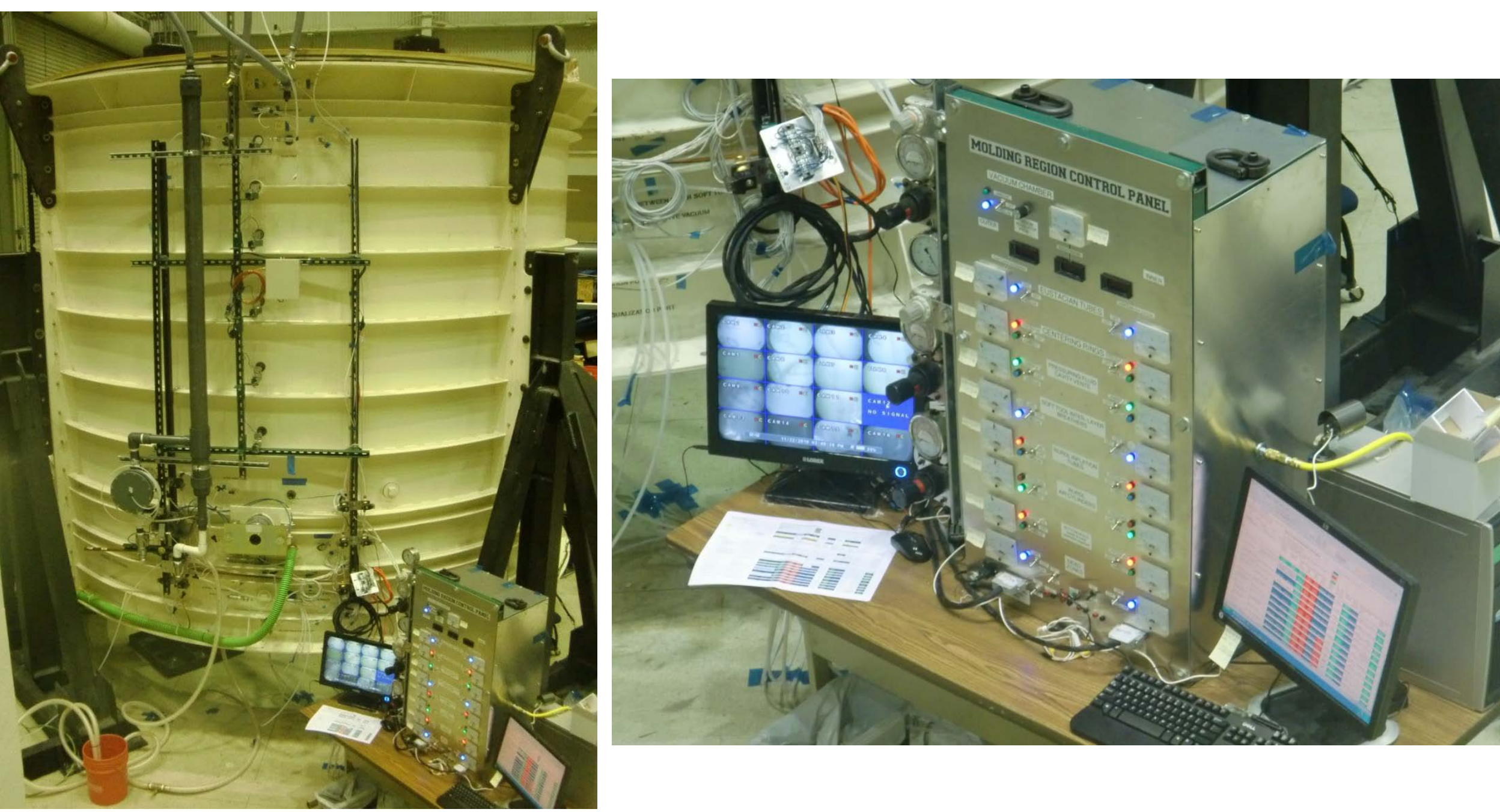


\section{VI.C.2 - Initial validation workpiece}

- VI.C.2.a - Layup and insertion into Molding Region

- VI.C.2.b - Infusion of workpiece

- VI.C.2.c - Results on infused workpiece

- VI.C.2.d - Validation of analytical tools for predicting infusion behavior 


\section{OIEC VI.C.2.a - Layup and insertion}

into Molding Region

- Manual fabric layup on foam core

- Inner fabric layup

- Resin distribution medium

- Adding Resin Distribution Medium (RDM)

- Lift workpiece into mold

- Installing core stoppers and temporary upper seal-flip-prevention devices

- Install lid 


\section{OFEC Initial validation workpiece -- Manual fabric layup on foam core*}

Hang fabric plies (over nylon release film - allows re-use of foam core just in case)

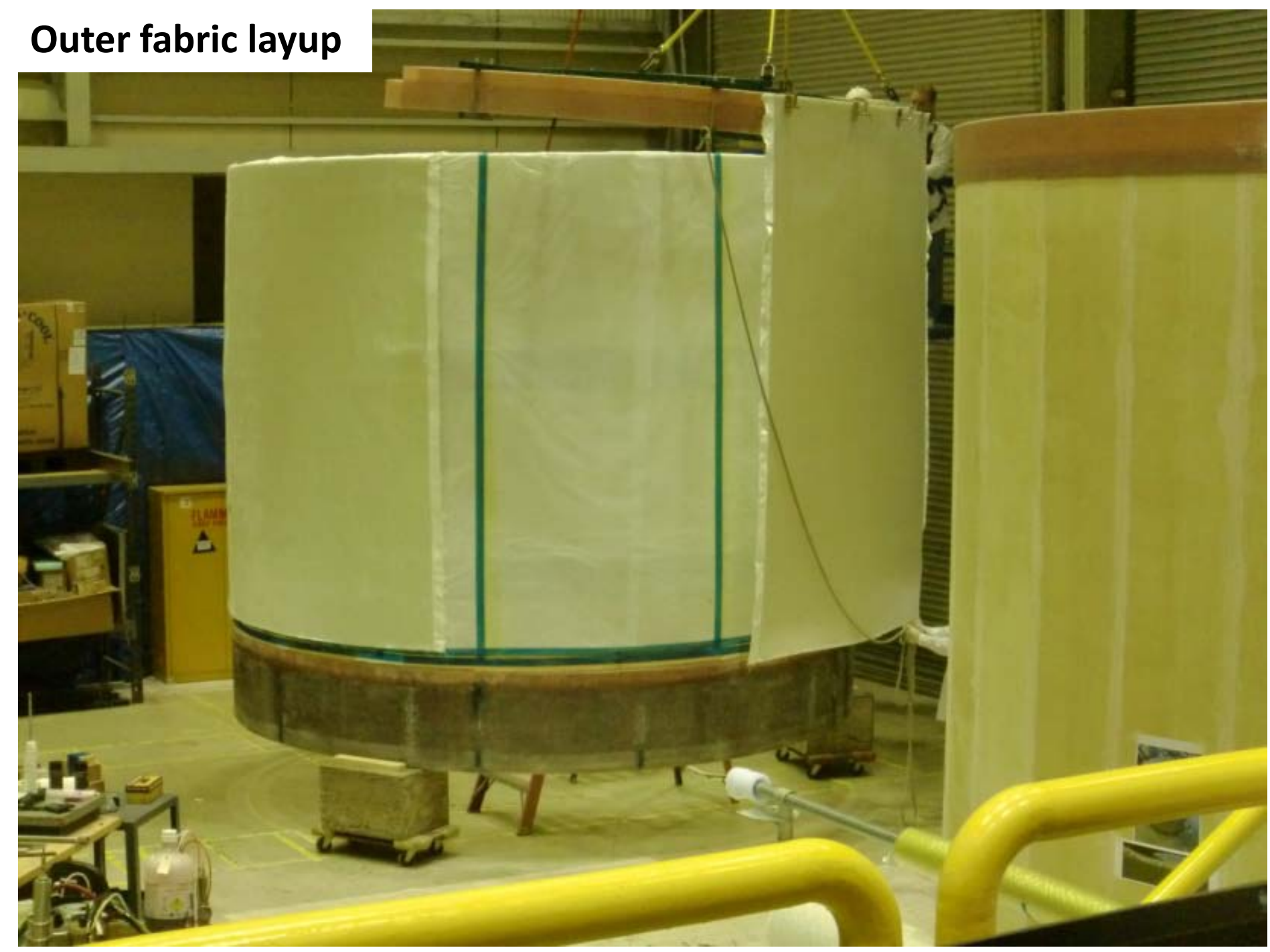

*Because of delays receiving acceptable pultruded planks, the foam core that had been used in Molding Region acceptance testing was used for the first Molding Region infusion trials instead of the pultruded plank core ring 


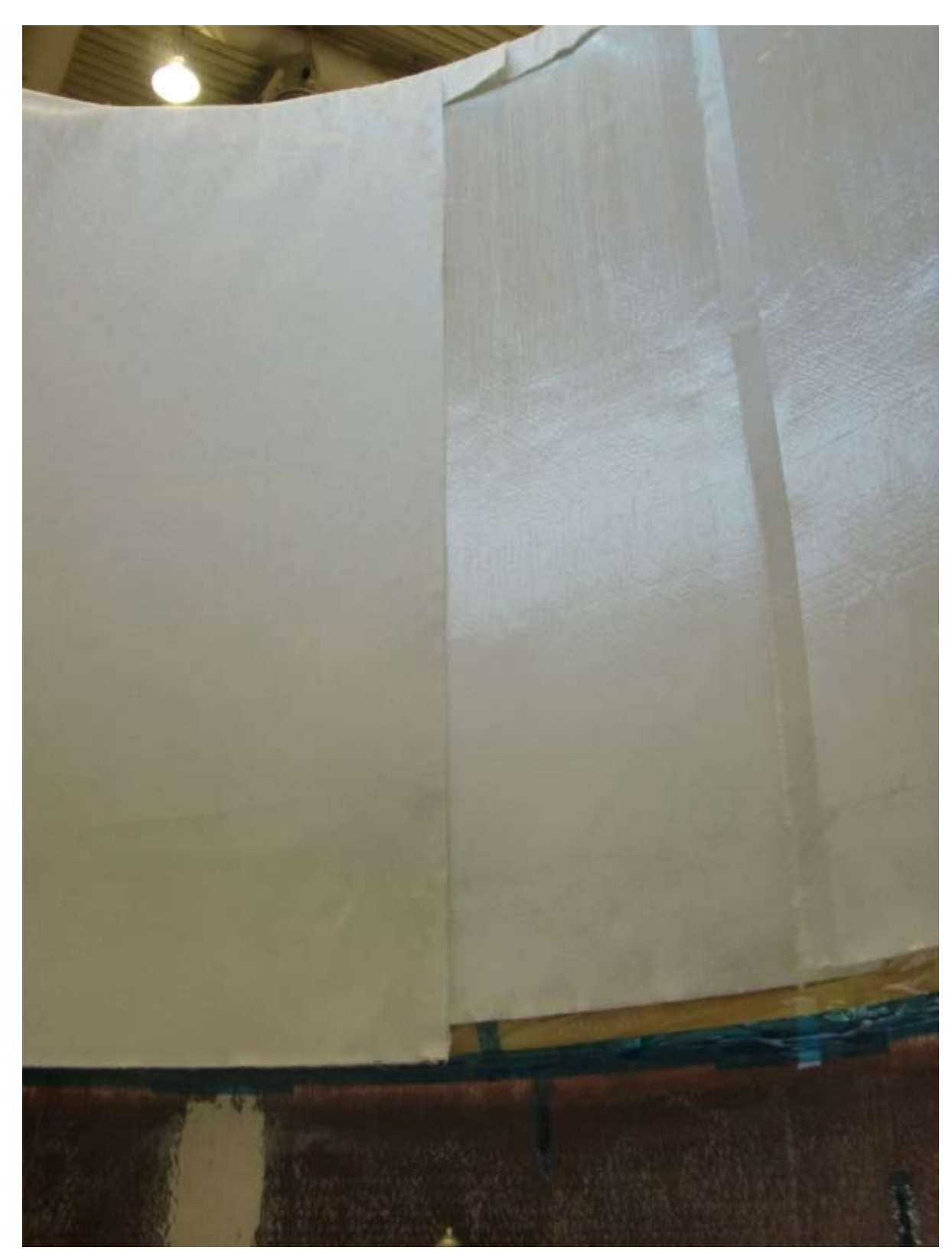




\section{OJEC \\ Add Resin Distribution Medium (RDM)}

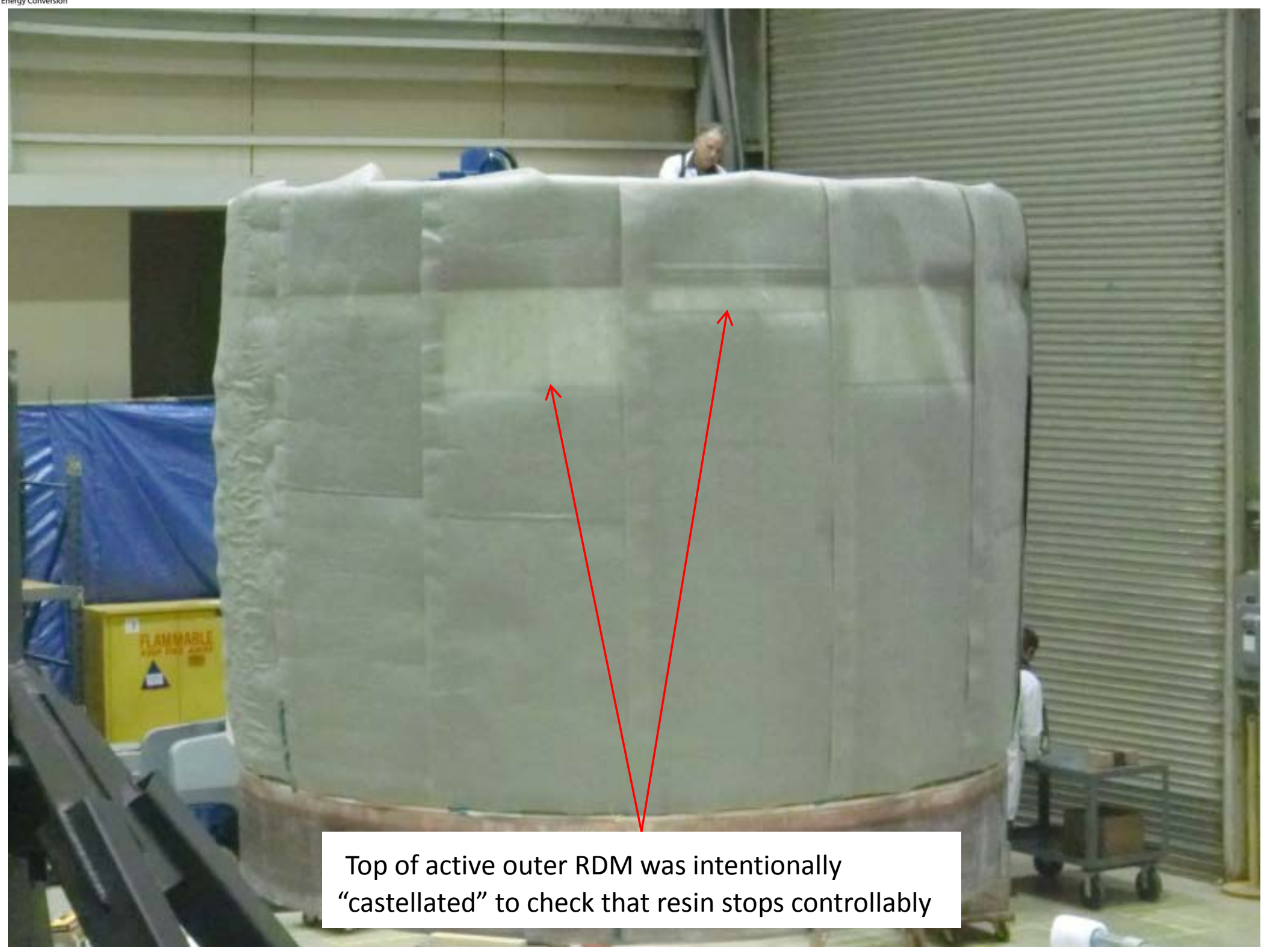




\section{OJEC \\ Lift workpiece into mold}
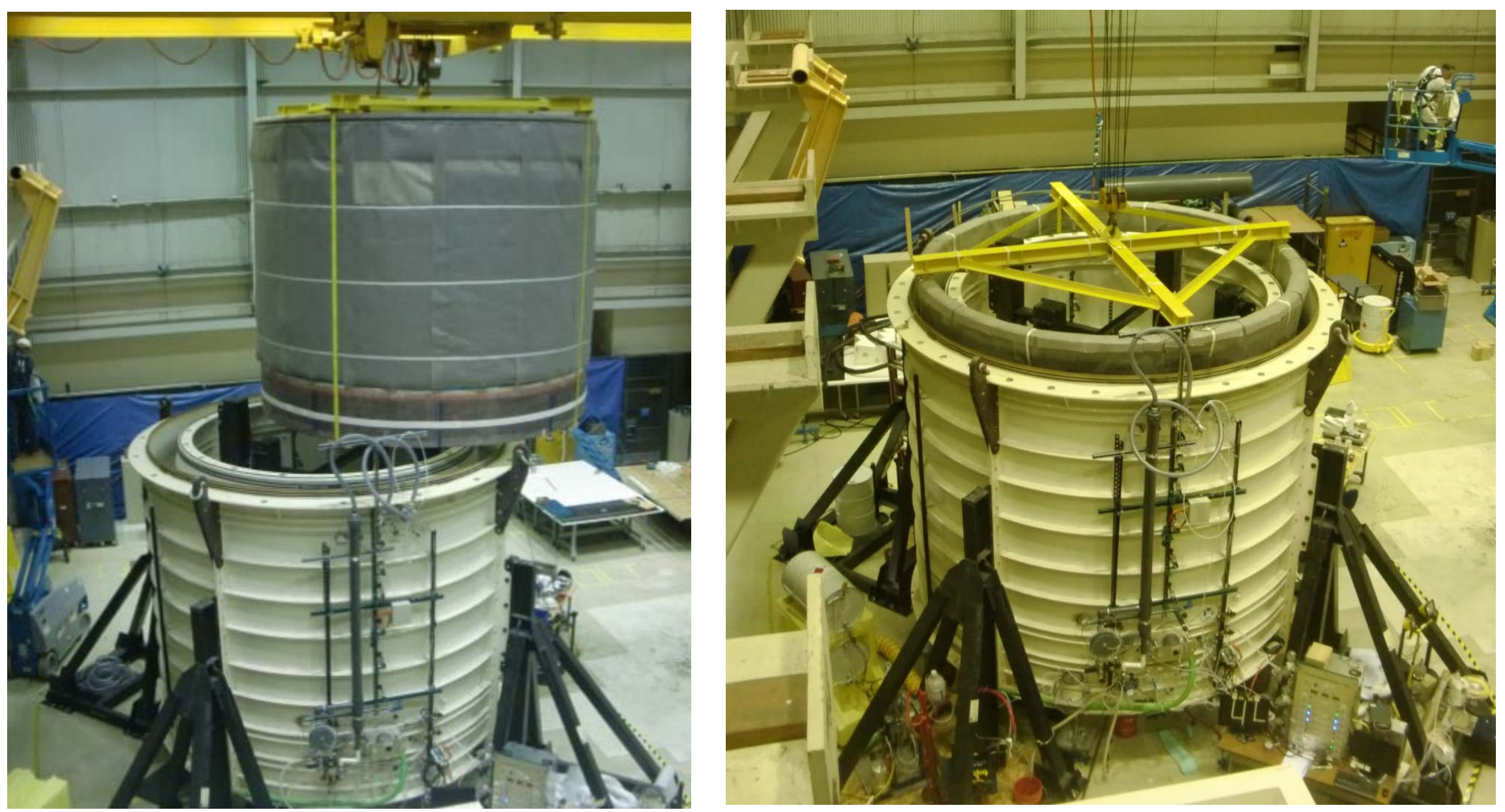

devices (foam blocks and foam strips) on top of workpiece
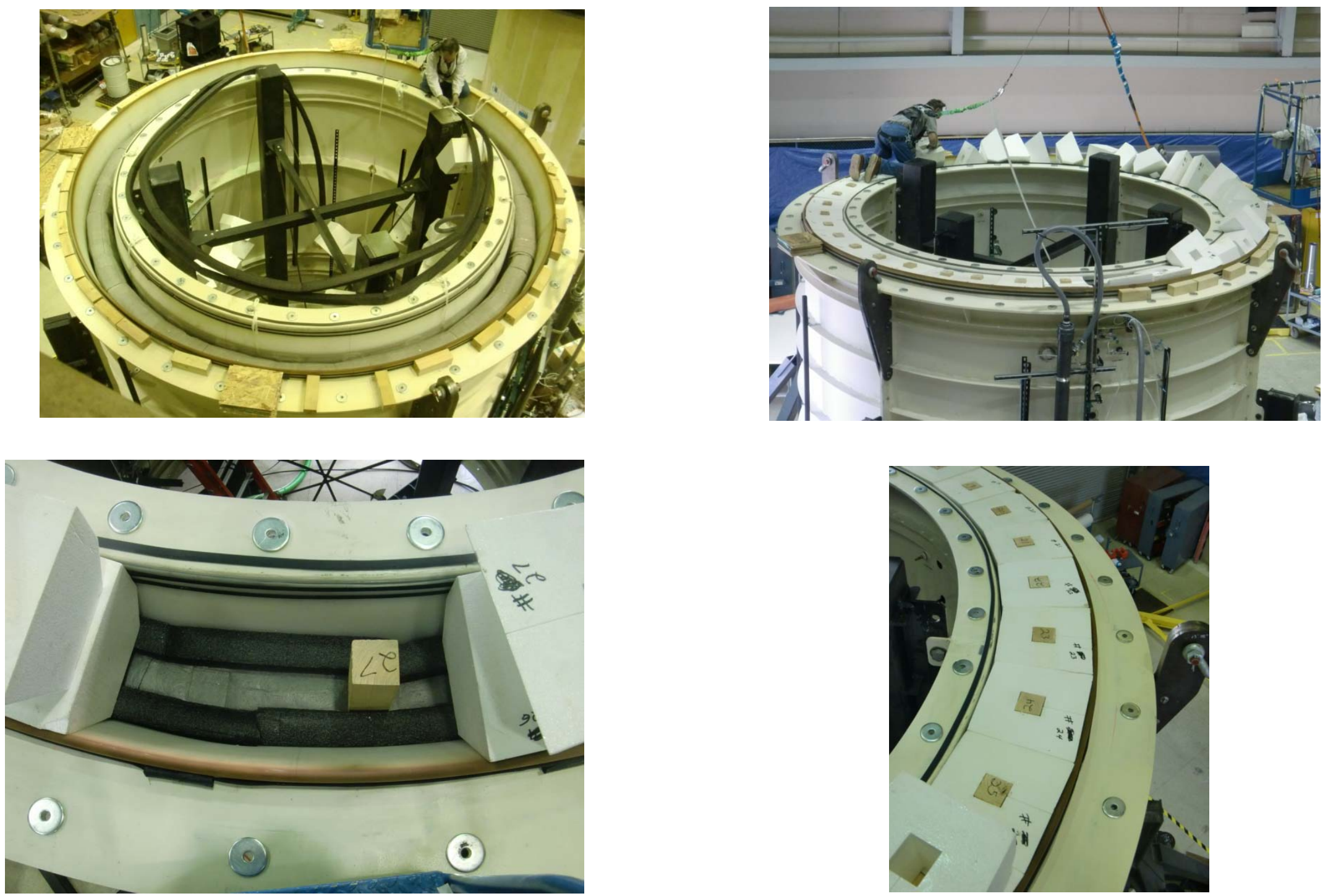


\section{OJEC}

Install lid

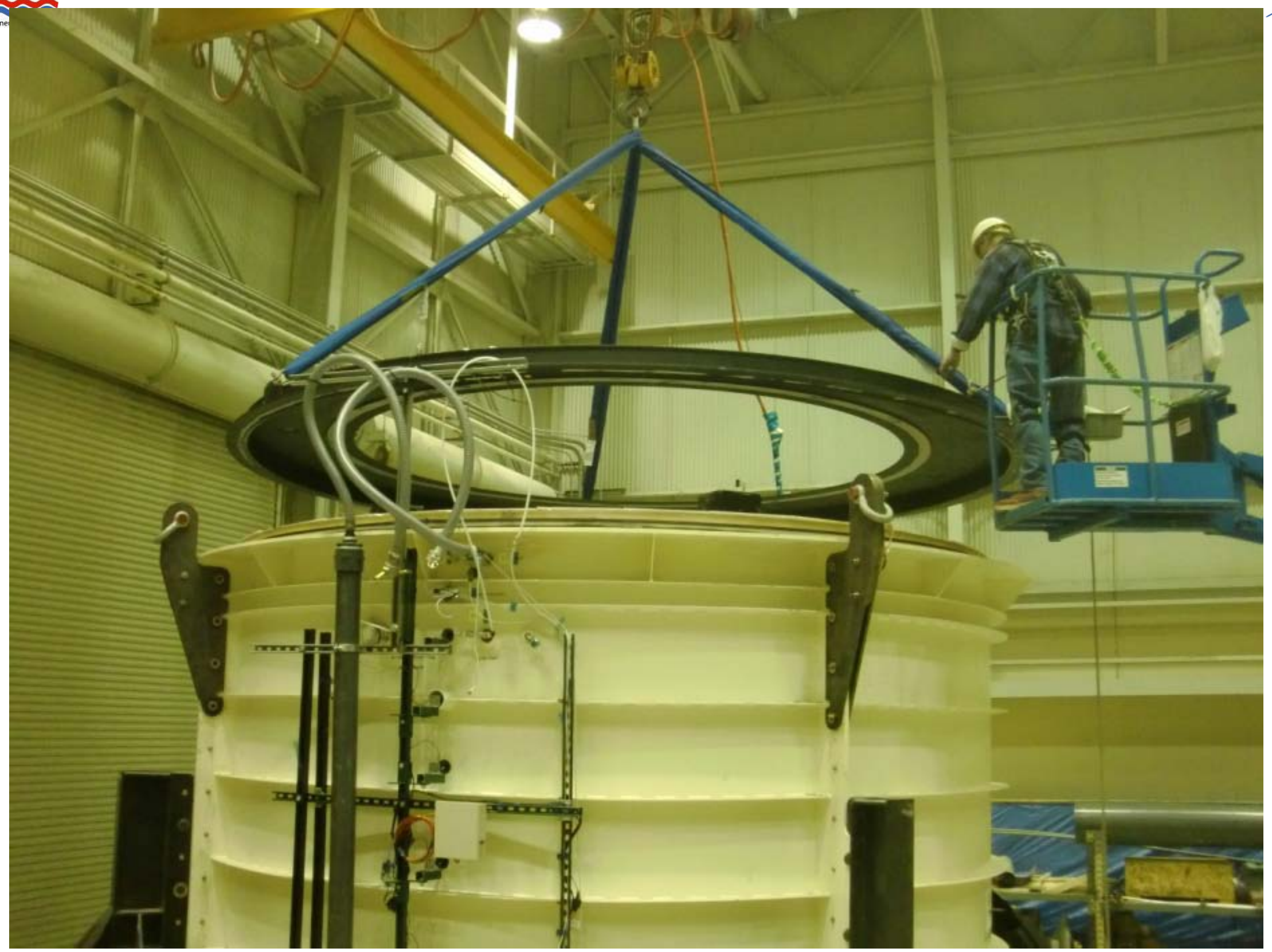




\section{VI.C.2.b - Infusion of workpiece}

- Labor requirements for infusion of workpieces

- Video monitor, regulators and gages, control panel, and computer that provides step-by-step running procedures and data note-taking

- Vacuum levels achieved

- Configuration of the three infusions

- Photos concerning the infusion process

- Infusion \#1: Inner facesheet - Cured lower portion

- Infusion \#2: Inner facesheet - Preparation to infuse remainder

- Infusion \#3: Outer facesheet, full height - Monitoring flow front position 


\section{Labor requirements for infusion of workpieces}

-The specialized apparatus enables infusion to be done by a 2-person crew

-About 1000 lbs. of resin was mixed and infused in 3 shots

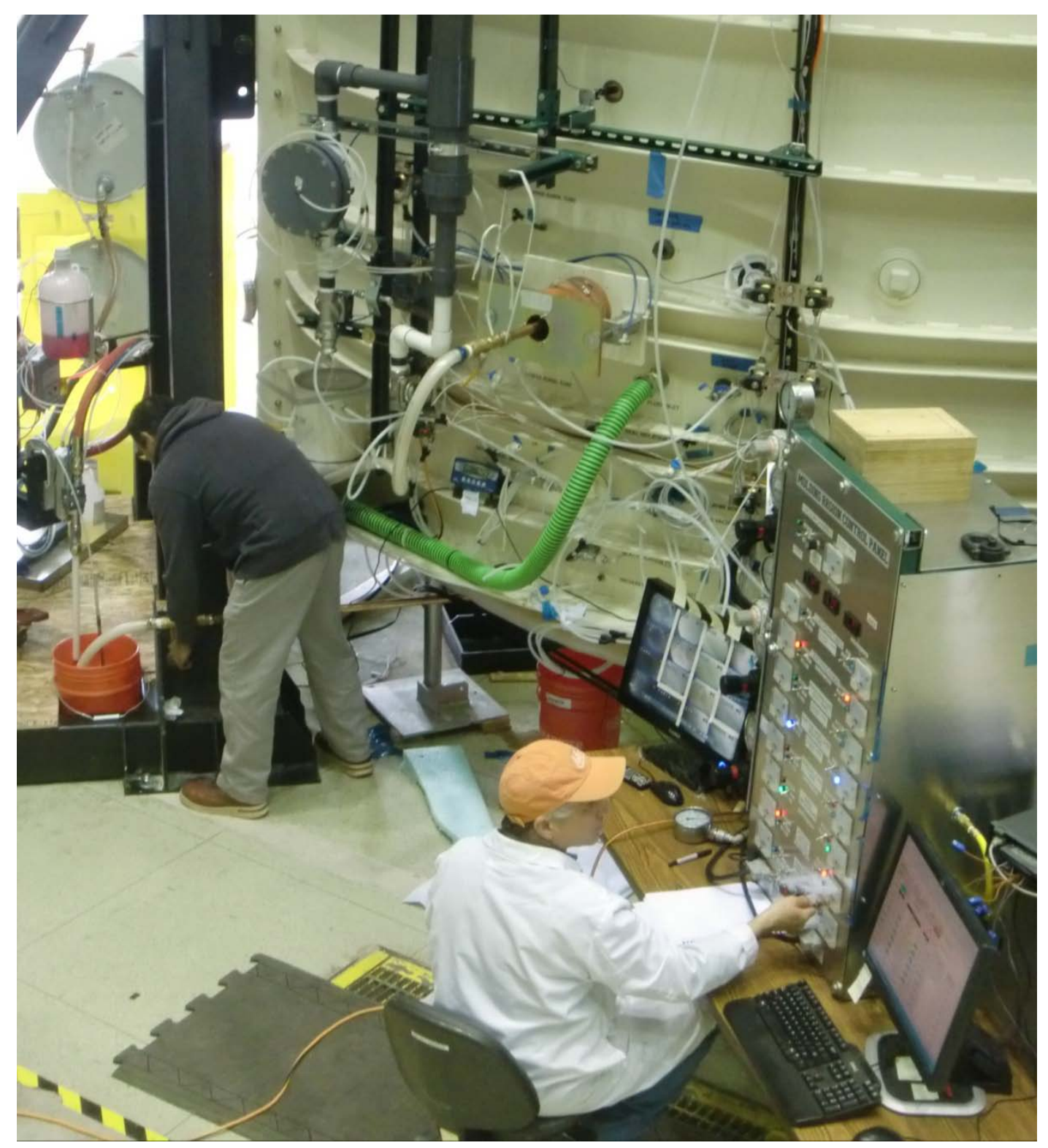




\section{OTEC Video monitor, regulators and gages, control panel, and}

computer that provides step-by-step running procedures and data note-taking

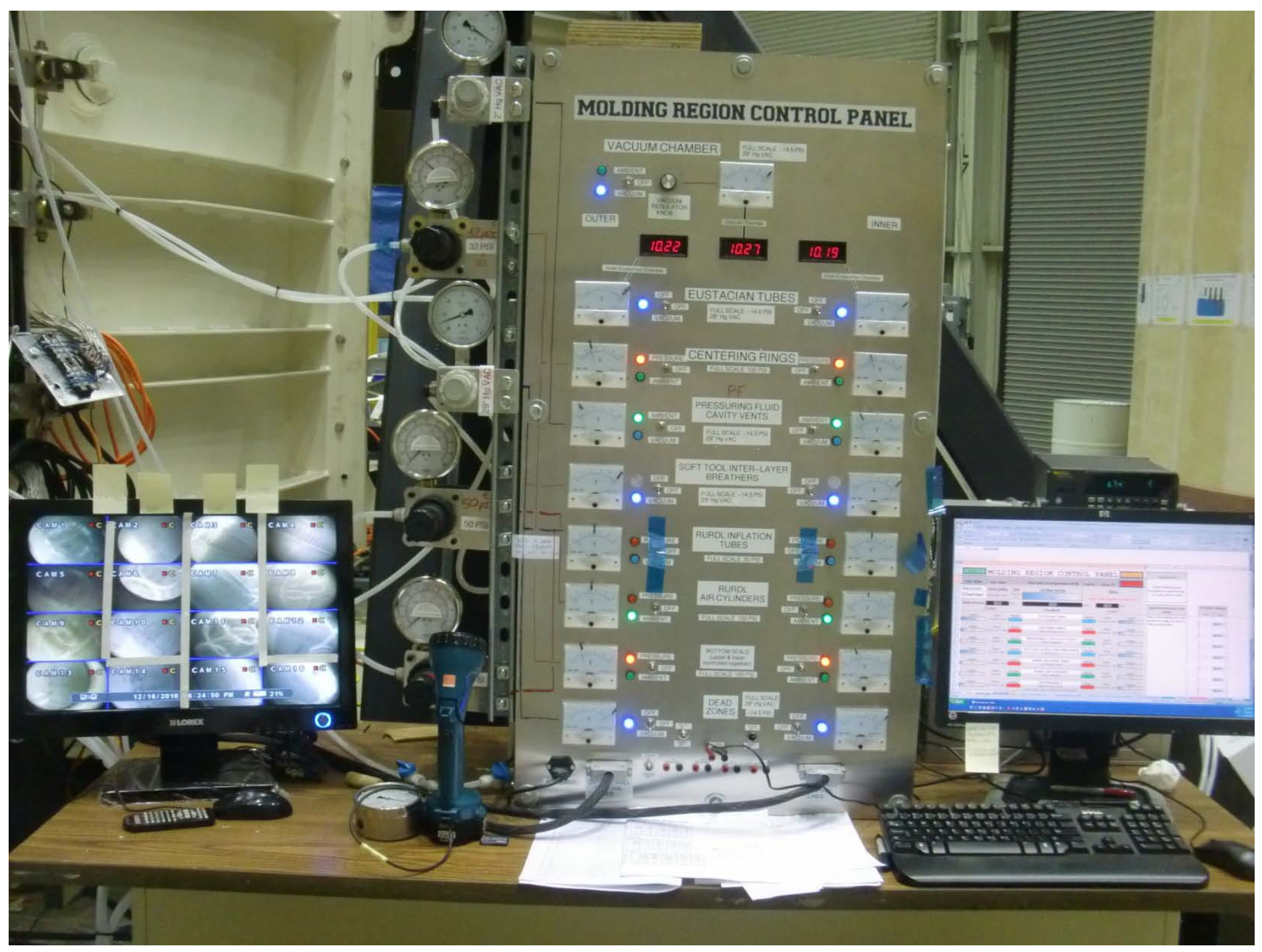




\section{OJEC \\ Vacuum levels achieved}

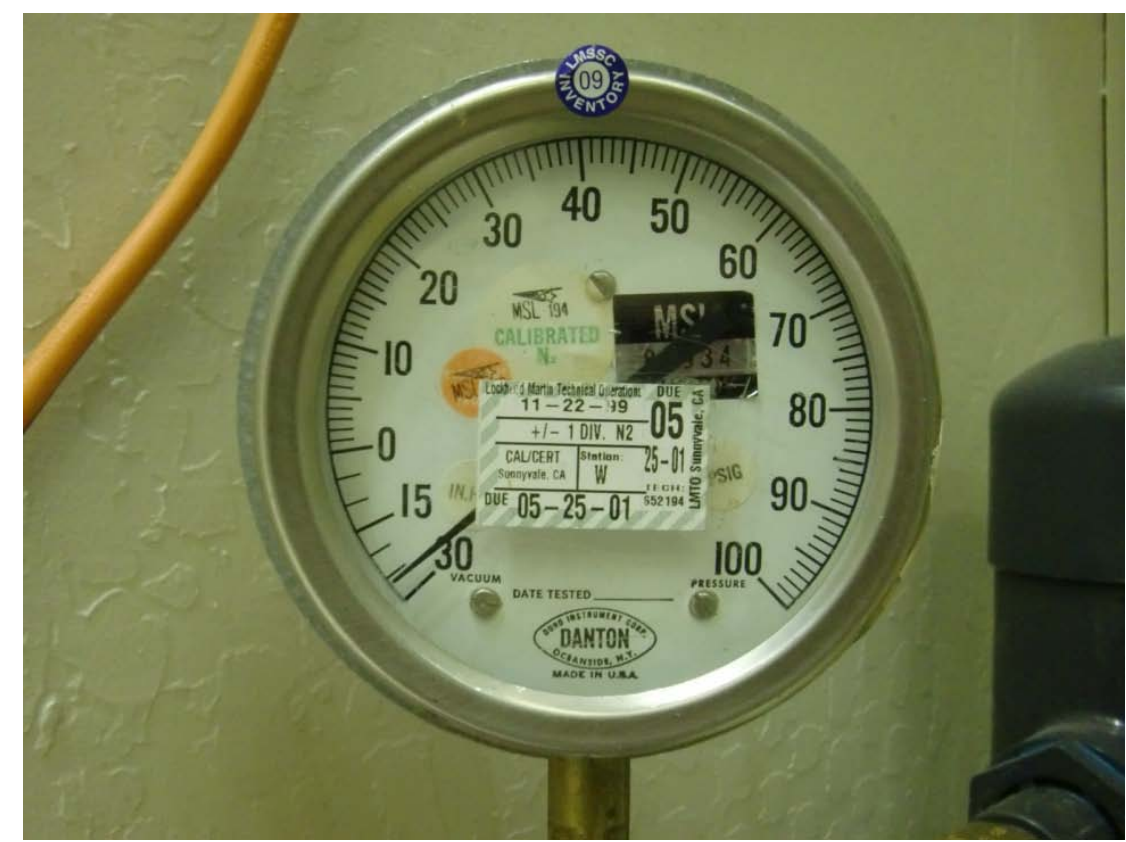

Source vacuum gage reads $26^{\prime \prime} \mathrm{Hg}$

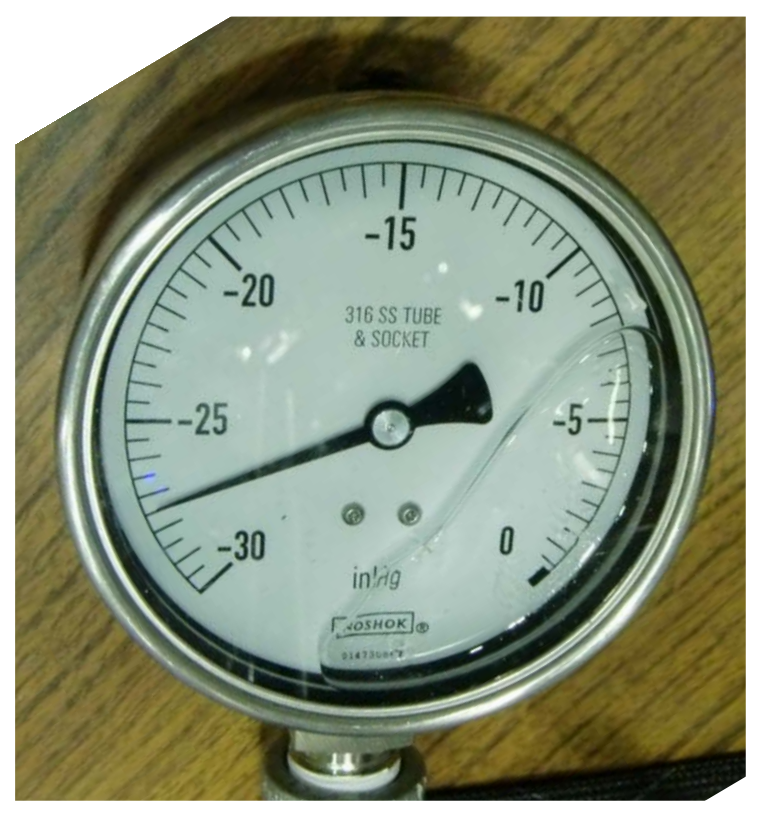

Vacuum chamber gage reads $27.5^{\prime \prime} \mathrm{Hg}$

Excellent vacuum achieved is the key to high-quality VARTM with no visible knitline 


\section{OJEC Configuration of the three infusions}

(only one side is shown)

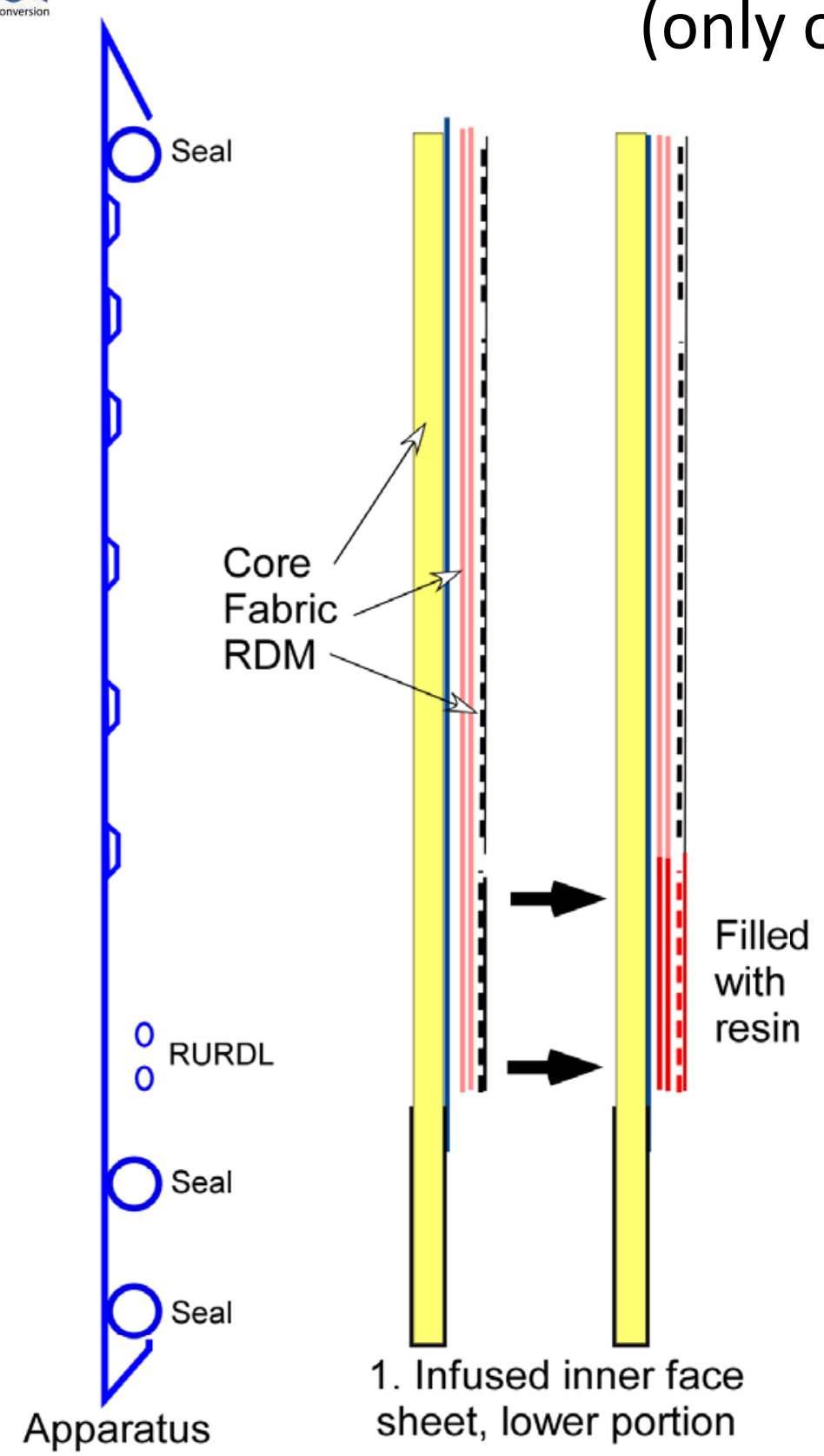

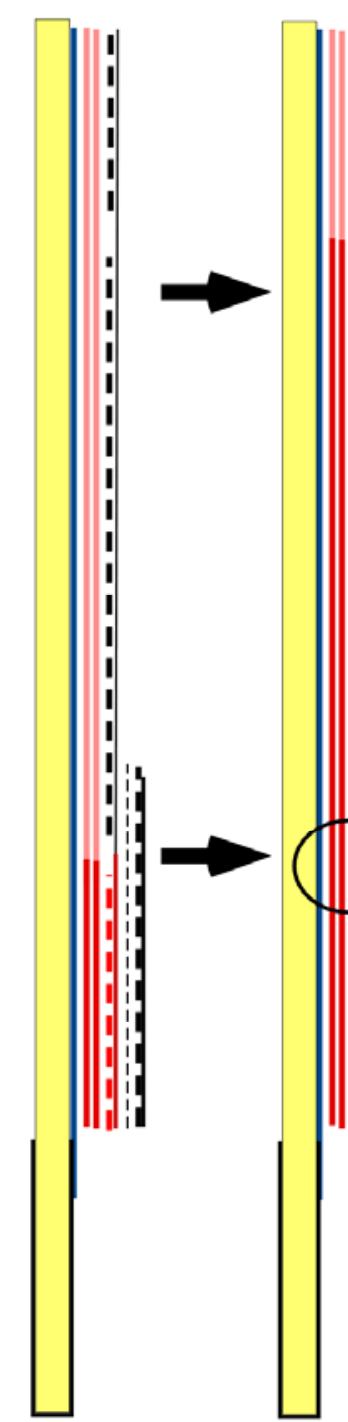

2. Infused inner face sheet, remainder
Knitline

Added extra RDM after first infusion to convey resin from RURDL up to uninfused portion of inner face sheet

Allowed stepwise infusion without having to lower the workpiece

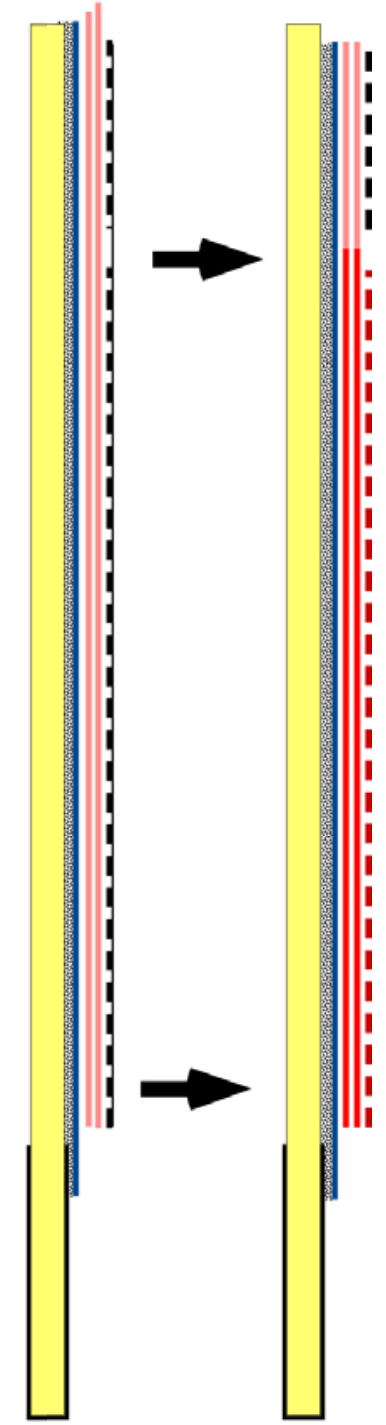

3. Infused outer face sheet 


\section{OTEC

Photos concerning the infusion process 
Cured lower portion

-This edge becomes the "knitline" after the rest of the inner facesheet is infused

-Face sheet filled to a uniform height all around

\section{et}
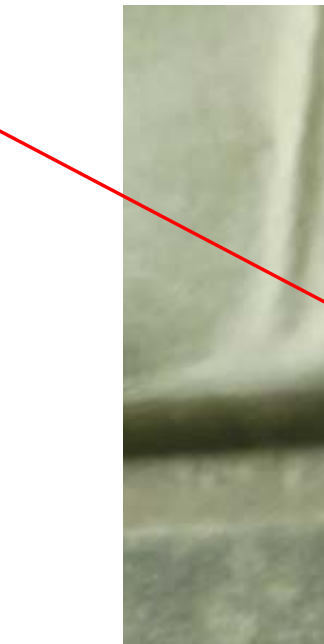


\section{OJEC}

\section{Infusion \#2: Inner facesheet - Preparation to infuse remainder}

Insertion of extra RDM to carry resin from the RURDL up to the not-yet infused region
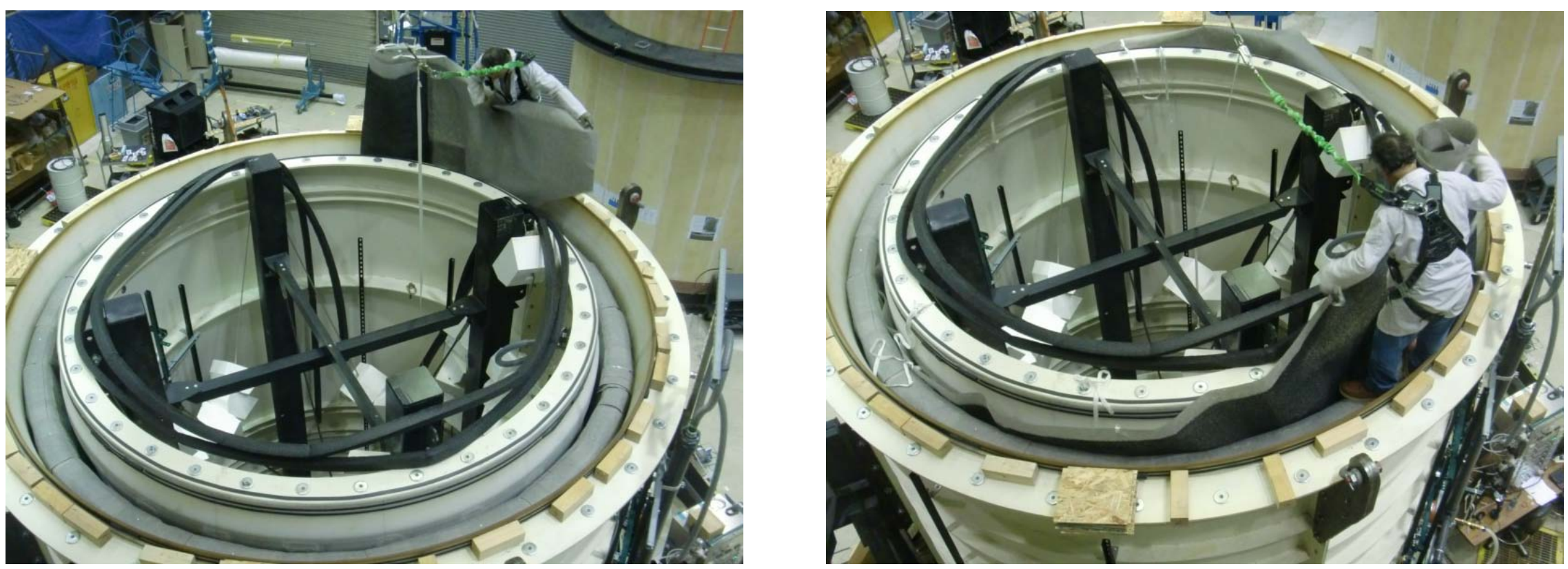
Infusion \#3: Outer facesheet, full height Monitoring flow front position

Before infusion

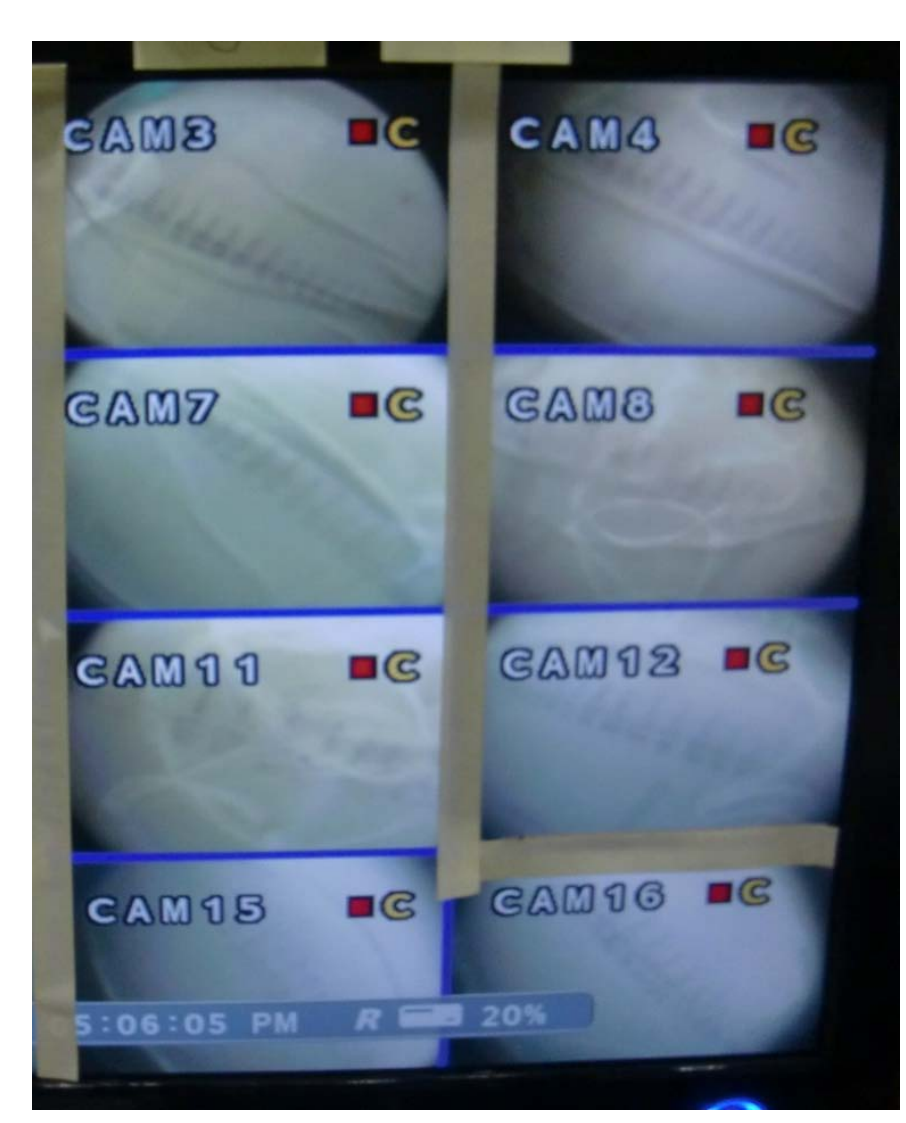

0 deg completing

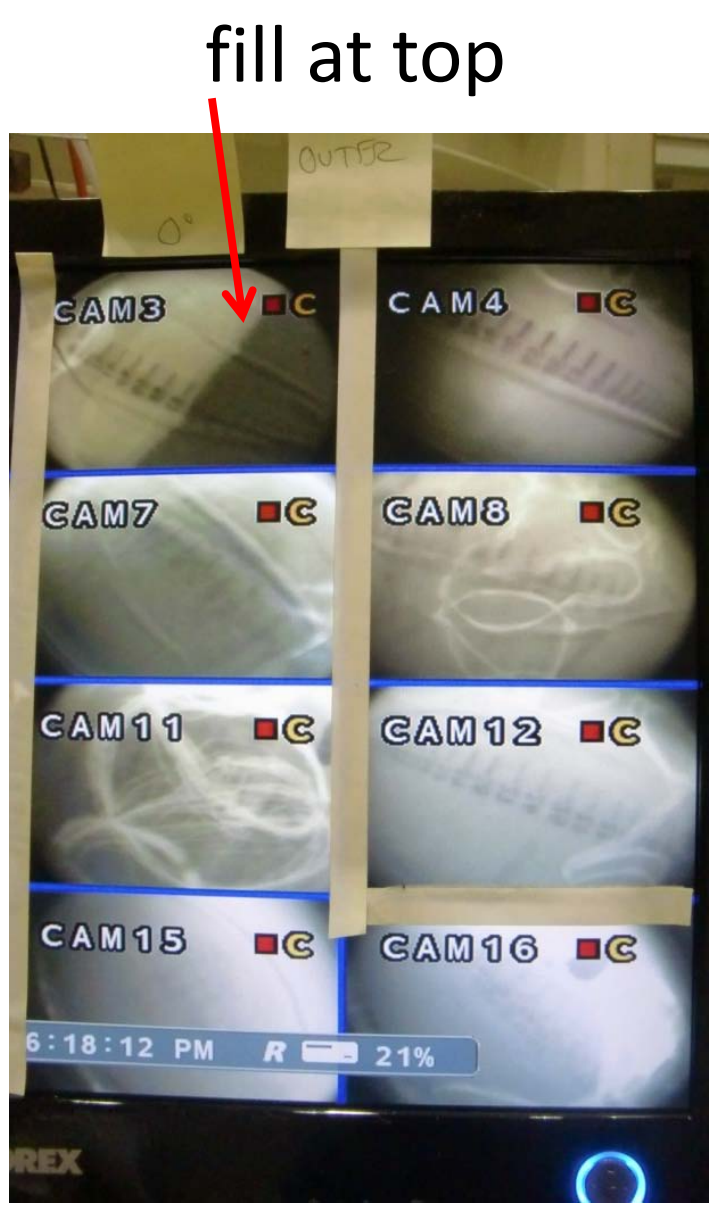

180 deg completing fill at top

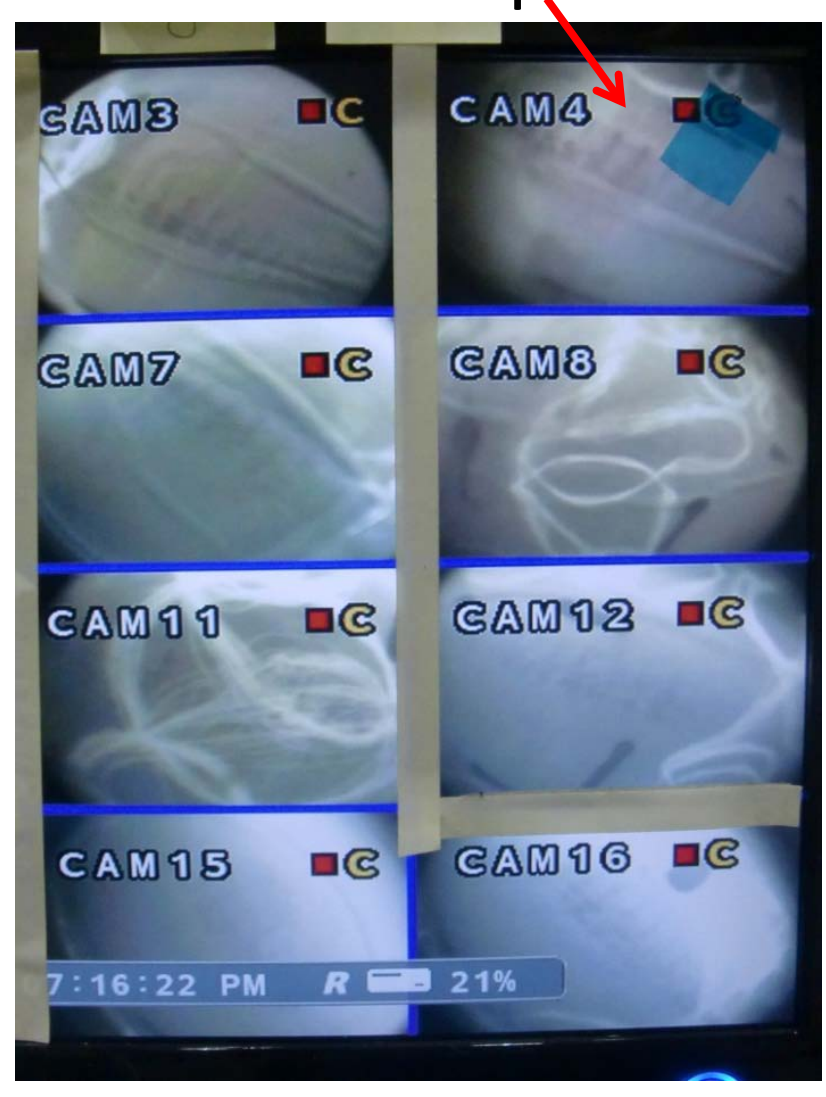


- Removing infused and cured workpiece from mold

- Inner face sheet showing uniform wet-out height

- Control of wet-out height

- Observations concerning longitudinal wrinkling in outer face sheet (only) of $4 \mathrm{~m}$ validation workpiece fabricated on foam core

- Understanding wrinkling observed in outer face sheet of $4 \mathrm{~m}$ workpiece, and path forward that should eliminate it

- Inner face sheet shows successful operation of RURDL and RIL mechanism

- Samples cut from finished $4 \mathrm{~m}$ diameter validation workpiece

- Results at knitline 
Removing infused and cured workpiece from mold

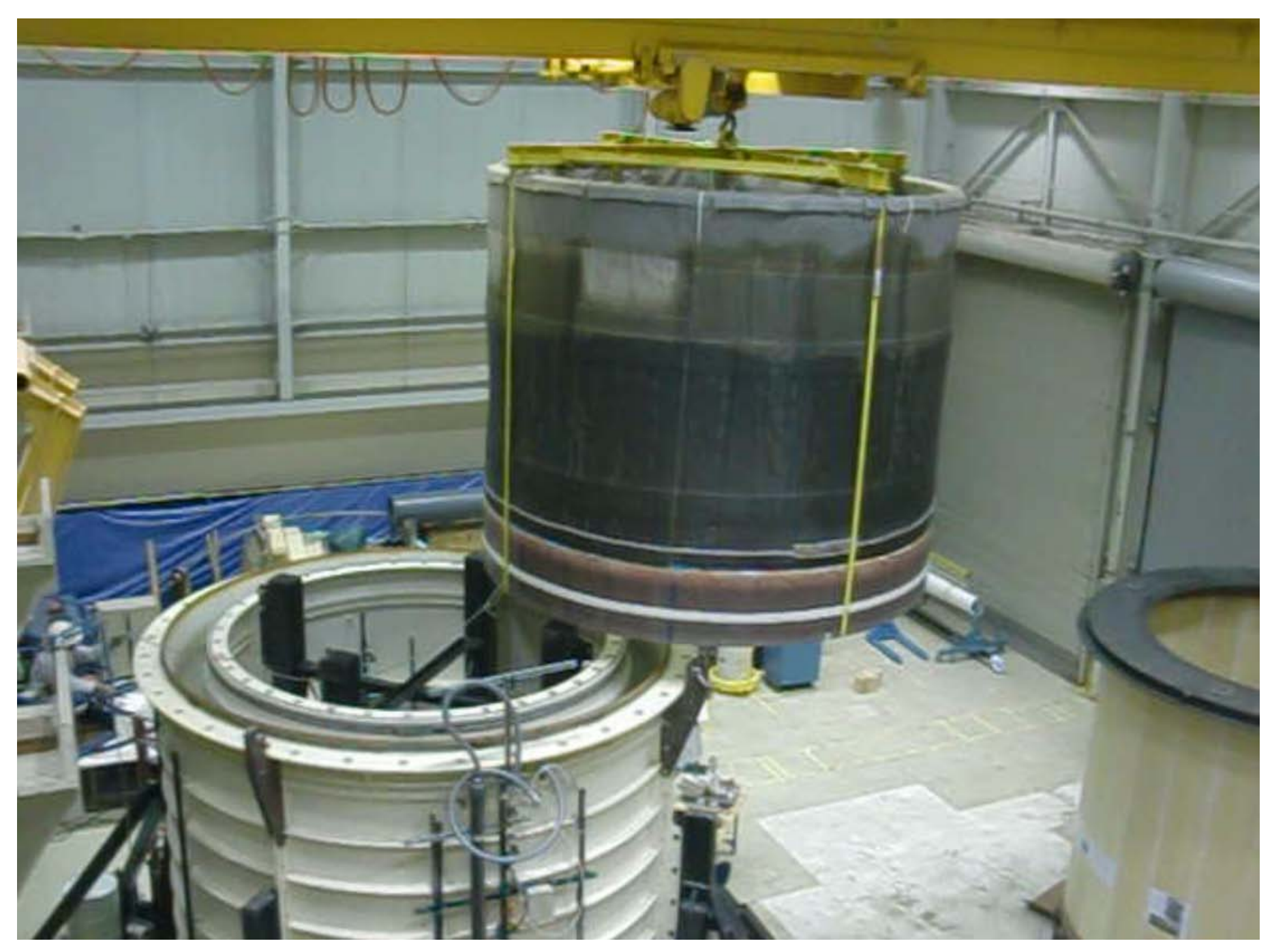




\section{Inner face sheet showing uniform wet-out height}

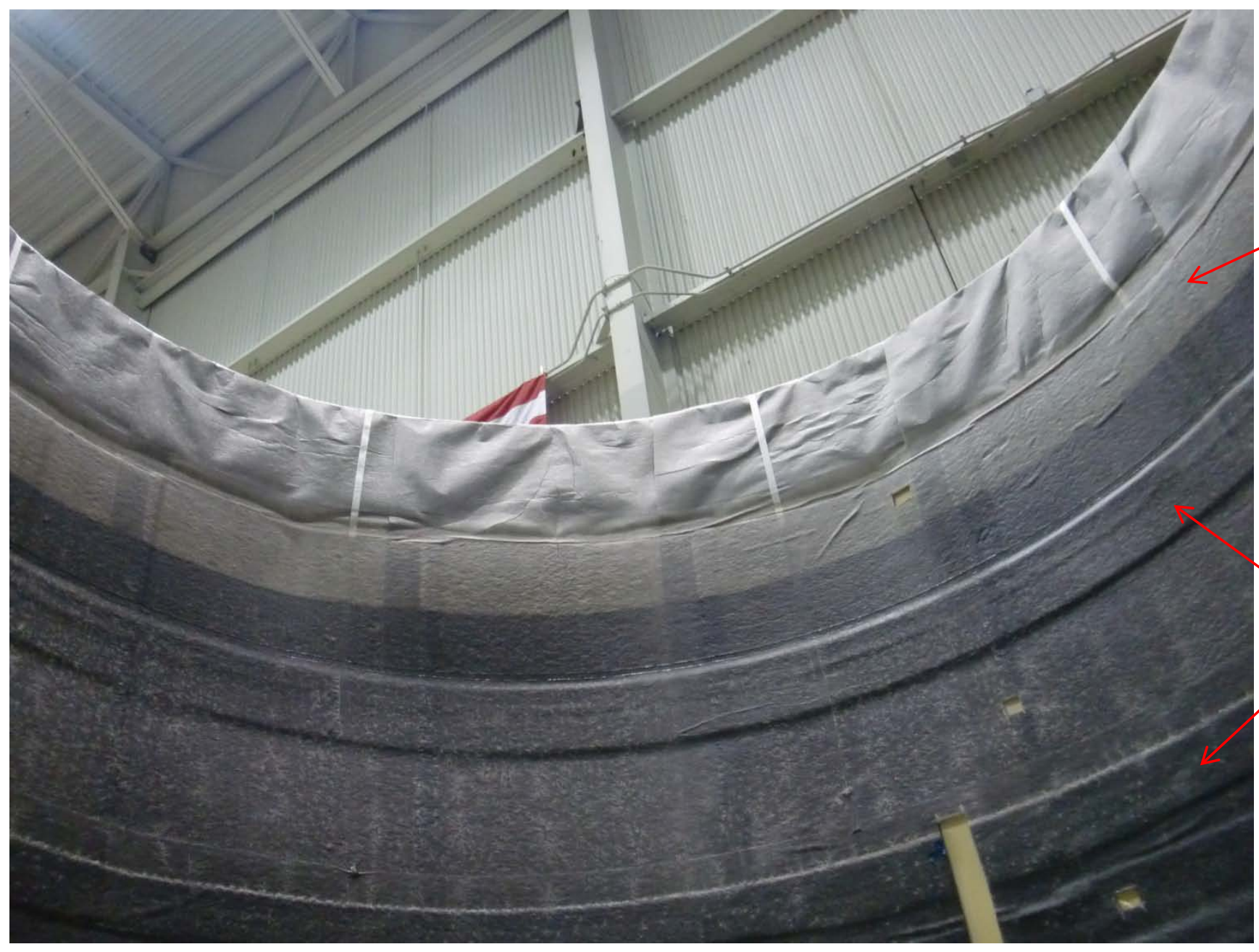

-As individual fabric tows continue to soak up resin after fill valve is closed, the resin in the RDM drops to a common liquid level, but the structural fabric stays filled at the maximum resin height. The RDM appearance can probably be improved by keeping the fill valve open longer than we did on this run.

-Ring patterns are from shear keys holding the foam core rings together, and overlaps of the double RDM. These are not part of the CWP design

-The flow front stops at a uniform height all around the circumference -This validates our method of controlling the flow front height for stepwise infusion 
 \\ Control of wet-out height}

Boundary of wet-out in the fabric

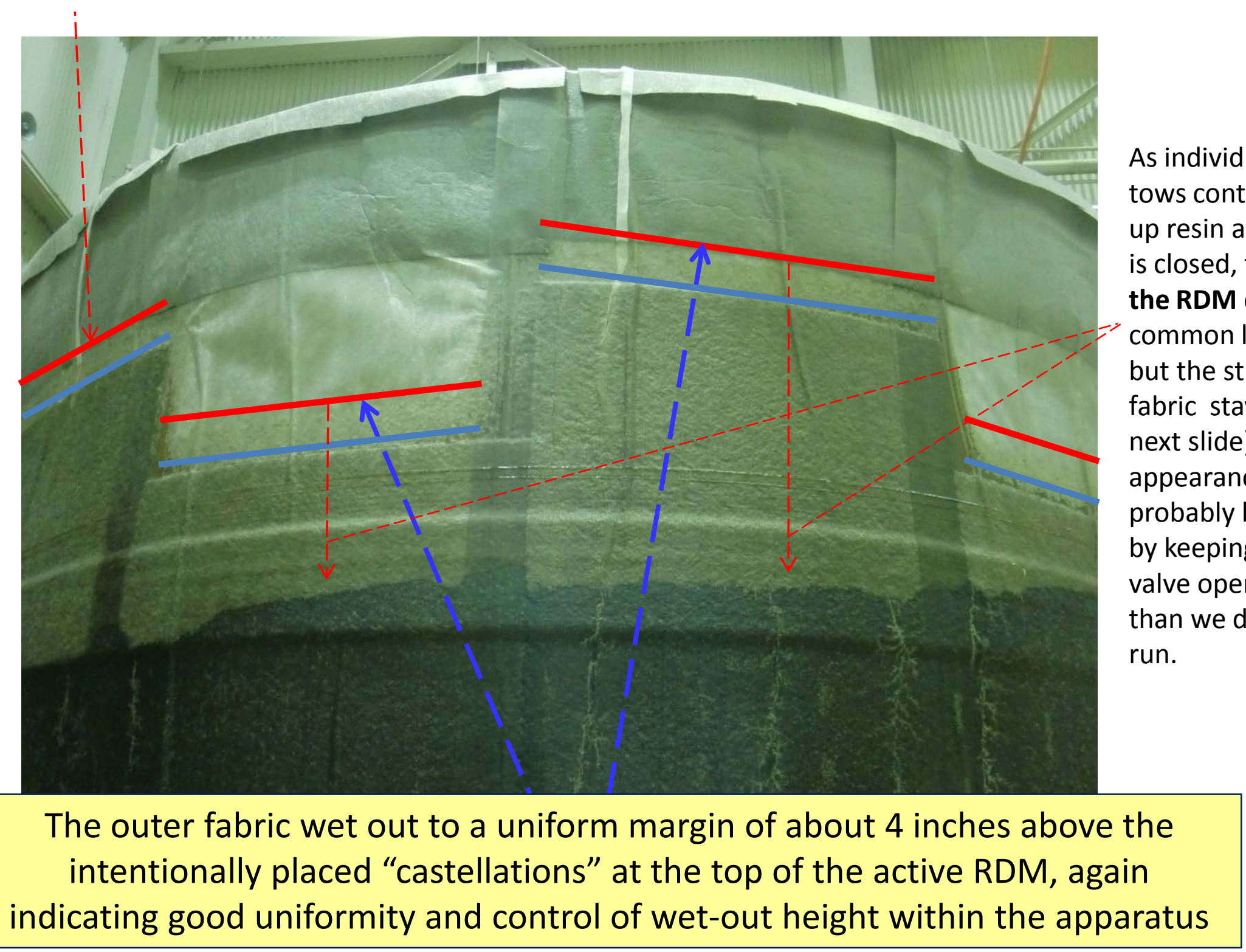

As individual fabric

tows continue to soak up resin after fill valve is closed, the resin in the RDM drops to a common liquid level, but the structural fabric stays filled (see next slide). The appearance can probably be improved by keeping the fill valve open longer than we did on this run. 

sheet (only) of $4 \mathrm{~m}$ validation workpiece fabricated on foam core

Proof-of-principles workpiece:

No longitudinal wrinkling

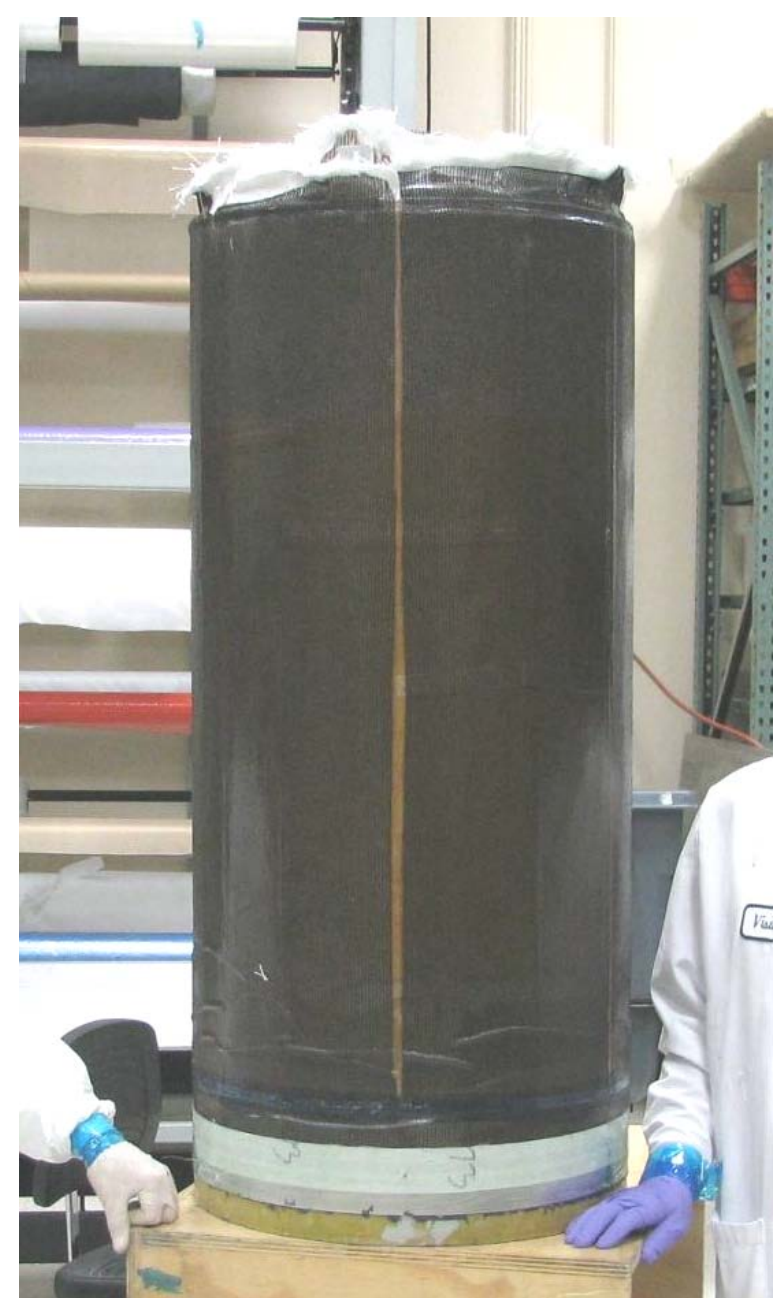

$4 \mathrm{~m}$ validation workpiece:

Got longitudinal wrinkling 
 workpiece, and path forward that should eliminate it}

\begin{tabular}{|c|c|c|c|c|}
\hline $\begin{array}{l}\text { Component } \\
\text { and } \\
\text { operations }\end{array}$ & $\begin{array}{l}\text { Prior and } \\
\text { current } \\
\text { results }\end{array}$ & Details of prior or current operations & Interpretation & Path forward \\
\hline $\begin{array}{l}\text { Outer fabric } \\
\text { dispensing } \\
\text { and molding }\end{array}$ & $\begin{array}{l}\frac{199^{\prime \prime} \text { Proof- }}{\text { of-Principles }} \\
\frac{\text { apparatus: }}{\text { No }} \\
\text { longitudinal } \\
\text { wrinkles }\end{array}$ & $\begin{array}{l}\text { 1. Bottom edges of all fabric rolls were } \\
\text { attached to a "pull ring" and were } \\
\text { pulled into the molding region axially } \\
\text { from fabric rolls and directly in contact } \\
\text { with the core. No tackifier was needed } \\
\text { or used. }\end{array}$ & $\begin{array}{l}\text { 1. Individual fabric strips } \\
\text { started out very close to } \\
\text { their final diameter, and } \\
\text { were free to slide over } \\
\text { each other } \\
\text { circumferentially as they } \\
\text { debulked onto the core } \\
\text { when vacuum was } \\
\text { pulled. }\end{array}$ & \\
\hline $\begin{array}{l}\text { Outer fabric } \\
\text { support } \\
\text { materials } \\
\text { and layup }\end{array}$ & $\begin{array}{l}\frac{4 \mathrm{~m} \text { Molding }}{\text { Region }} \\
\text { tested by } \\
\text { itself: } \\
\text { Got } \\
\text { longitudinal } \\
\text { wrinkles in } \\
\text { outer face } \\
\text { sheet }\end{array}$ & $\begin{array}{l}\text { 1. We used an available foam core because } \\
\text { the pultrusions were late. } \\
\text { 2. To be sure we didn't crush the weak } \\
\text { foam core by possible resin shrinkage } \\
\text { effects, we put breather cloth under the } \\
\text { outer face sheet. This inadvertently } \\
\text { created excess circumference in the } \\
\text { fabric and RDM. } \\
\text { 3. Because this was a standalone } \\
\text { workpiece, individual fabric strips were } \\
\text { draped over the top of the foam core. } \\
\text { They billowed out, creating additional } \\
\text { excess circumference. } \\
\text { 4. Fabric also hung away from workpiece in } \\
\text { between the intermediate shear keys, } \\
\text { creating additional excess circumference } \\
\text { 5. Some sprayable tackifier was used to } \\
\text { help hold the fabric strips in place. }\end{array}$ & $\begin{array}{l}\text { 1. The breather debulks } \\
\text { substantially when } \\
\text { vacuum bag pressure is } \\
\text { applied, forming } \\
\text { wrinkles in the overlaid } \\
\text { fabric and RDM. } \\
\text { 2. The billowing from } \\
\text { draping probably also } \\
\text { contributed to wrinkling } \\
\text { 3. Circumference changes } \\
\text { at shear keys may have } \\
\text { contributed to wrinkling } \\
\text { 4. The tackifier may have } \\
\text { prevented the fabric } \\
\text { strips from sliding over } \\
\text { each other at their } \\
\text { edges, contributing to } \\
\text { wrinkling. }\end{array}$ & $\begin{array}{l}\text { 1. There will not be any } \\
\text { breather fabric with } \\
\text { regular pultruded core. } \\
\text { 2. Fabric dispensing bibs } \\
\text { should keep fabric } \\
\text { against core as it is } \\
\text { dispensed vertically, and } \\
\text { tension in dispensing } \\
\text { mechanisms should } \\
\text { tend to keep it from } \\
\text { wrinkling. } \\
\text { 3. We plan to get rid of } \\
\text { shear keys by going to } \\
\text { staggered core planks. } \\
\text { This will get rid of } \\
\text { excess circumference } \\
\text { there. } \\
\text { 4. No tackifier will be used }\end{array}$ \\
\hline
\end{tabular}


Inner face sheet shows successful operation of RURDL and RIL mechanism

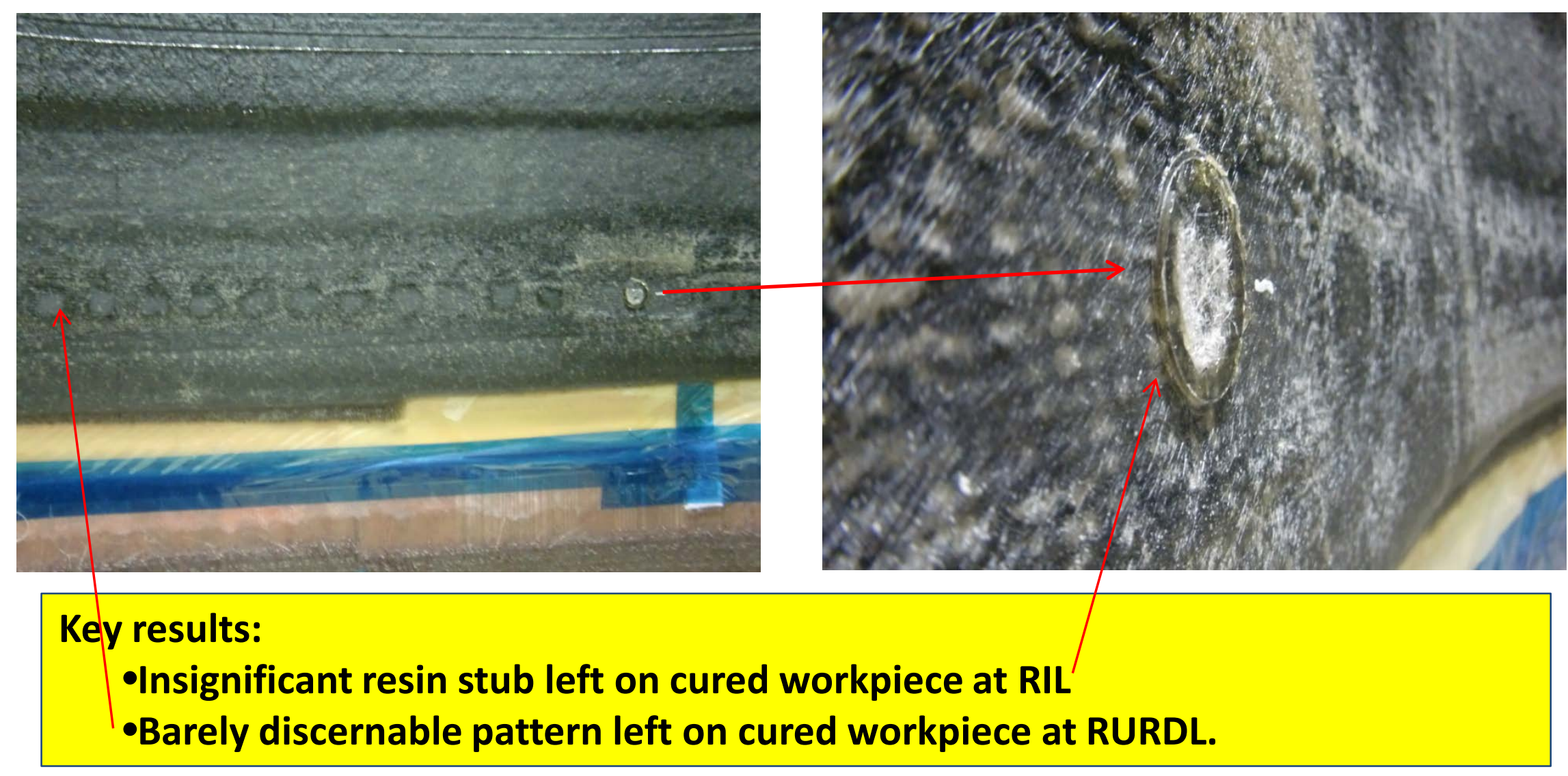

Behavior of the apparatus is validated for repeated infusions with minimal expendable material replacement (only the RIL itself) between infusions 

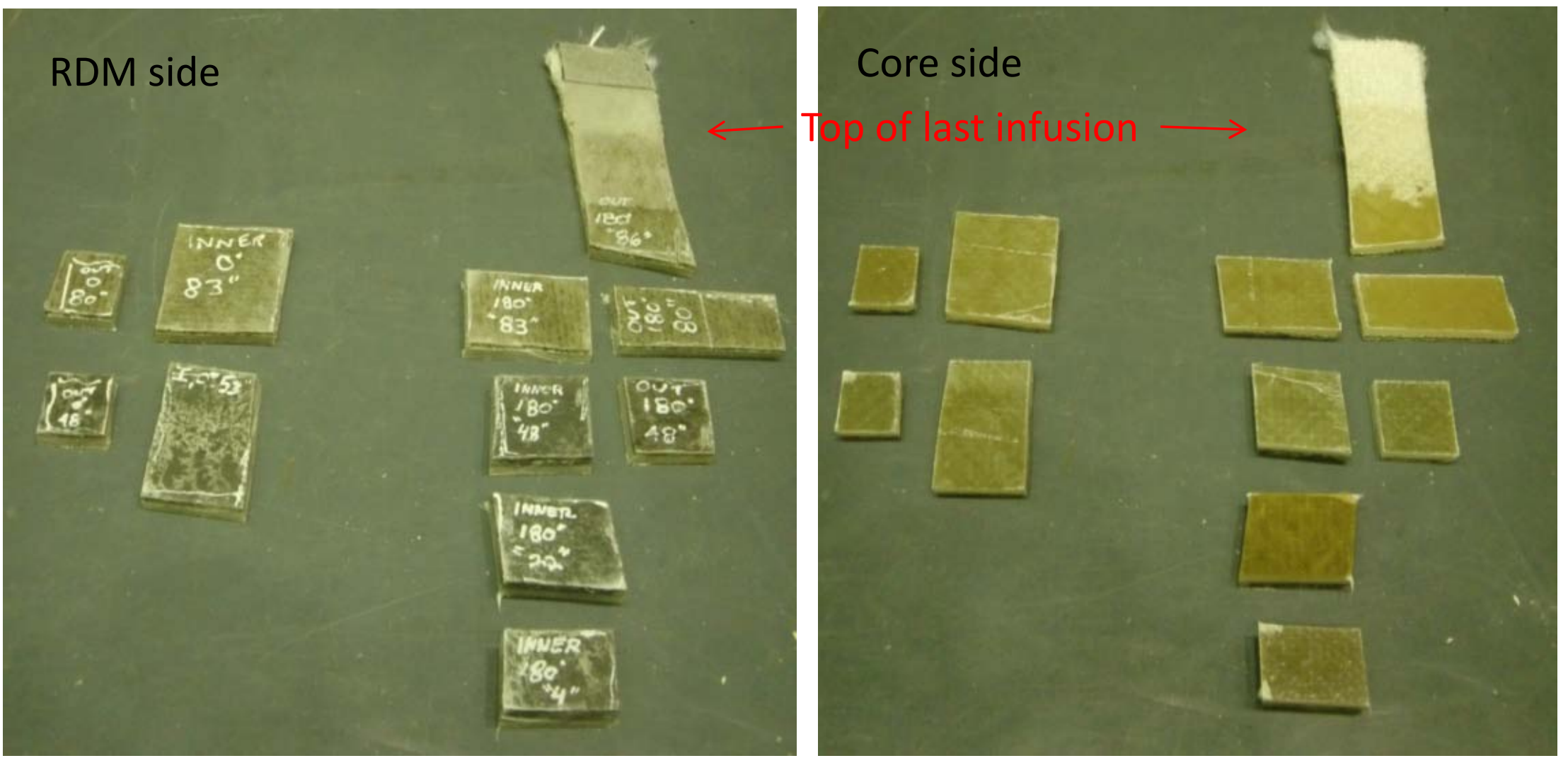

Laminate is fully wet-out everywhere, including regions where resin level dropped in the RDM during cure 


\section{Results at knitline}

Key result: The knit-line between infusion steps is indistinguishable from the base laminate.

A slight color change on the external surface of the laminate (due to different catalyst \% on two infusions due to lab temperature differences) serendipitously reveals where the knitline is.

The stepwise infusion molding process is validated 


\section{VI.C.2.d - Validation of analytical tools for predicting infusion behavior (fill time and resin consumption)}

- Predicting resin quantity and fill time including lines and valves

- Fill pattern and resin consumption

- Fill time corrected for viscosity vs. temperature, compared to prediction 


\begin{tabular}{|c|c|c|c|}
\hline Number of panels & 1 & Mixture, in & Mixture, cc \\
\hline Panel length, in & 82.00 & & \\
\hline \begin{tabular}{|l|} 
Panel width, in \\
\end{tabular} & 501.39936 & & \\
\hline Fabric thickness, in & 0.237 & & \\
\hline $\begin{array}{l}\text { Margin in bottom of reservoir: } 1 / 2 " \text { depth } \times 2 " \\
\text { diameter: in^3 }\end{array}$ & & 0.0 & 0 \\
\hline RIL inside diam., in. & 1.000 & & \\
\hline RIL inside area, in^2 & 0.785 & & \\
\hline RIL length, in. & 184 & & \\
\hline RIL volume, in^3, cc & & 144.4 & 2366.9 \\
\hline RDL length, ID, in. & 501.40 & & \\
\hline RDL ID, in & 1.316 & & \\
\hline RDL area (in^2) & 1.360 & & \\
\hline RDL vol in^3, cc & & 681.9 & 11174.3 \\
\hline Active RDM thickness, in & 0.12 & & \\
\hline Active RDM porosity & 0.88 & & \\
\hline Active RDM mixture quantity, in^3 & & 4347.3 & 71239.0 \\
\hline Outer RDM thickness, in & 0.02 & & \\
\hline Outer RDM porosity & 0.67 & & \\
\hline Outer RDM mixture quantity, in^3 & & 550.9 & 9028.2 \\
\hline VDM mixture quantity, in^33 & & 0.0 & 0 \\
\hline Fabric mixture content & 0.49328 & & \\
\hline Fabric mixture volume, in^3, cc & & 4806.6 & \begin{tabular}{|l|l|}
78766.19093 \\
\end{tabular} \\
\hline Resin in gaps between planks, in^3 & & 0.0 & \\
\hline VDL length, in., vol in^3 & 0 & 0.0 & 0 \\
\hline VEL's: How many? & 0 & & \\
\hline VEL inside diam, in. & 0.170 & & \\
\hline Total VEL length, volume & 48 & 0.0 & 0 \\
\hline Fill time, Upper reservoir volume, fabric fraction u & 0 & 0.0 & $0 \%$ \\
\hline Total calculated mixture: in^3, cc & & 10531.2 & 172575 \\
\hline \begin{tabular}{|l} 
Flushing margin and mixture required: \\
\end{tabular} & $0 \%$ & 0.0 & 0 \\
\hline Contingency and mixture required: & $0 \%$ & 0.0 & 0 \\
\hline Total mixture to be mixed, $\mathrm{lb}, \mathrm{in}^{\wedge} 3, \mathrm{cc}$ & 380.1 & 10531.2 & 172575 \\
\hline Catalyst PHMB by wgt; Catalyst PHMB by vol & 1.986097319 & & 1.899705173 \\
\hline Density $(g / c c)$-Master batch, avg, hardener & 1.01305008 & 1.020 & 1.039 \\
\hline Master batch $(g)$ & 169214 & Natalyst (g) & 3361 \\
\hline Master batch (Ib) & 373 & Catalyst (Ib & 7.403 \\
\hline Master batch (cc) & 167034 & Tatalyst (cd & 3235 \\
\hline Master batch (gallons) & 44.1 & Catalyst (ga & 0.9 \\
\hline
\end{tabular}

\section{Input from LMSSC flat panel VARTM model}

$\frac{\text { Calculate acceptable size of resih inlet line, subfeeds, and fill valve }}{\text { Expected fill time without }}$

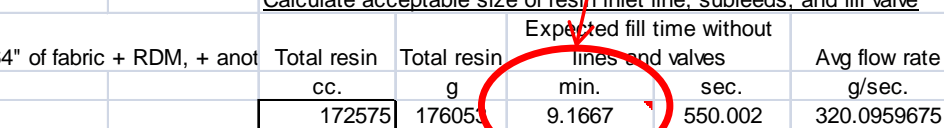

\begin{tabular}{|c|c|c|c|}
\hline cc. & g & min. & sec. \\
\hline 172575 & 17605: & 9.1667 & 550.002 \\
\hline & & & \\
\hline
\end{tabular}

$1.020 \mathrm{E}+06 \mathrm{~g} / \mathrm{m}^{\wedge} 3$

$1.00 \mathrm{E}+02 \mathrm{~g} /\left(\mathrm{Pa}-\mathrm{sec}^{\wedge} 2-\mathrm{m}\right)$

8084

Pressure drop through main feed tube a inches

Tube length

wall thickness, outer dial $\quad 0.0675$

Inside diameter, inches "=D9-2*C9"

Flow area

Fluid viscosity

Average mass flow rate $320.0959675 \mathrm{~g} / \mathrm{sec}$

$184^{7}$ meters 4.67360

$\begin{array}{ll} & 4.67360 \\ 1 & 0.02540\end{array}$

\begin{tabular}{r|r}
1 & 0.02540 \\
\hline 0.7850 & $5.06 \mathrm{E}-04$ \\
\hline
\end{tabular}

\begin{tabular}{|l|l|} 
Reynolds number & 340.6000932 Per Shepard \\
\hline
\end{tabular}

\begin{tabular}{l|l|l|l} 
Friction factor $f$ & 0.187903648 Per Marks p. Friction factor prime $(=f / 4)$ & 0.046976 Per Marks p. 4-66
\end{tabular}

\begin{tabular}{|l|r|}
\hline Estimated pressure drop for feed tube & $4.17 \mathrm{E}+04 \mathrm{~Pa}$ \\
\hline
\end{tabular}

\begin{tabular}{llll} 
Feed tube mass $(\mathrm{g})$, flow & 301.57 & 767.36 & 0.39 \\
\hline
\end{tabular}

Pressure drop through fill valve

$\begin{array}{rlll}\text { Measure laminate fiber v/o } & \text { Pength of flow passage inside valve bod: } & 1 & 0.02540 \text { was }=2^{*} 0.75 * \mathrm{D} 20 / 0.375\end{array}$

Tube nomina size, OD, inches

\begin{tabular}{|l|r|r|}
\hline Flow passage inside diameter, inches & 0.75 & 0.01905 \\
\hline
\end{tabular}

\begin{tabular}{|l|r|r|}
\hline Flow area & 0.4416 & $2.85 \mathrm{E}-04$ \\
\hline
\end{tabular}

Fluid viscosity

\begin{tabular}{|l|r|} 
Average mass flow rate $320.0959675 \mathrm{~g} / \mathrm{sec}$ \\
\hline
\end{tabular}

\begin{tabular}{l|l} 
Reynolds number & $4.54 \mathrm{E}+02$ Per Shepard \\
\hline
\end{tabular}

Friction factor $f \quad 0.140927736$ Per Marks $p$. Friction factor prime $(=f / 4)$ Estimated pressure drop for valve $\quad 7.17 \mathrm{E}+02 \mathrm{~Pa}$

Pressure drop through RDL inches meters

Number of sub-feed tube 2

\begin{tabular}{|l|l|l|}
\hline Tube length & 250.69968 \\
\hline Lall
\end{tabular}

\begin{tabular}{|l|l|l|}
\hline wall thickness, outer dial & 0 & 1.31590339 \\
\hline
\end{tabular}

\begin{tabular}{ll|l|l|} 
Inside diameter, inches $"=\mathrm{D} 31-2^{*} \mathrm{C} 31 "$ & 1.316 & 0.03342 \\
\hline
\end{tabular}

\begin{tabular}{|l|l|l|r}
\hline Flow area & 1.360 & $8.77 \mathrm{E}-04$ \\
\hline
\end{tabular}

Fluid viscosity

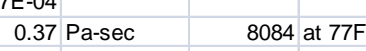

\begin{tabular}{|l|l|l|l|} 
Average mass flow rate & $160.0479838 \mathrm{~g} / \mathrm{sec}$ & Fluid velocity & $1.404 \mathrm{E}-01 \mathrm{~m} / \mathrm{sec}$
\end{tabular}

\begin{tabular}{l|l|l} 
Reynolds number & $1.29 \mathrm{E}+02$ Per Shepard
\end{tabular}

\begin{tabular}{|l|l|l|l}
\hline Friction factor $f$ & 0.494526095 Per Marks p. Friction factor prime $(=f / 4)$ & 0.123632 Per Marks p. 4-66
\end{tabular}

\begin{tabular}{|l|r}
\hline Estimated pressure drop for subfeed & $9.48 \mathrm{E}+03 \mathrm{~Pa}$ \\
\hline
\end{tabular}

\begin{tabular}{llll} 
subfeed tube mass $(\mathrm{g}), \mathrm{fl}$ & 1992 & 625.29 & 3.19 \\
\hline
\end{tabular}

$\begin{array}{ll}\text { Total pressure drop for valve, feed, subfeeds } & \text { 5.19E+04 } \mathrm{Pa}\end{array}$

Atmospheric pressure

Total Pressure to fill part in same time

Corrected fill time for 1 atm avail pressur

Estimated pot life of resin
$1.00 \mathrm{E}+05 \mathrm{~Pa}$

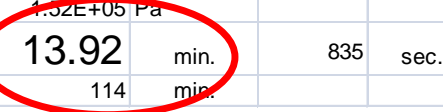




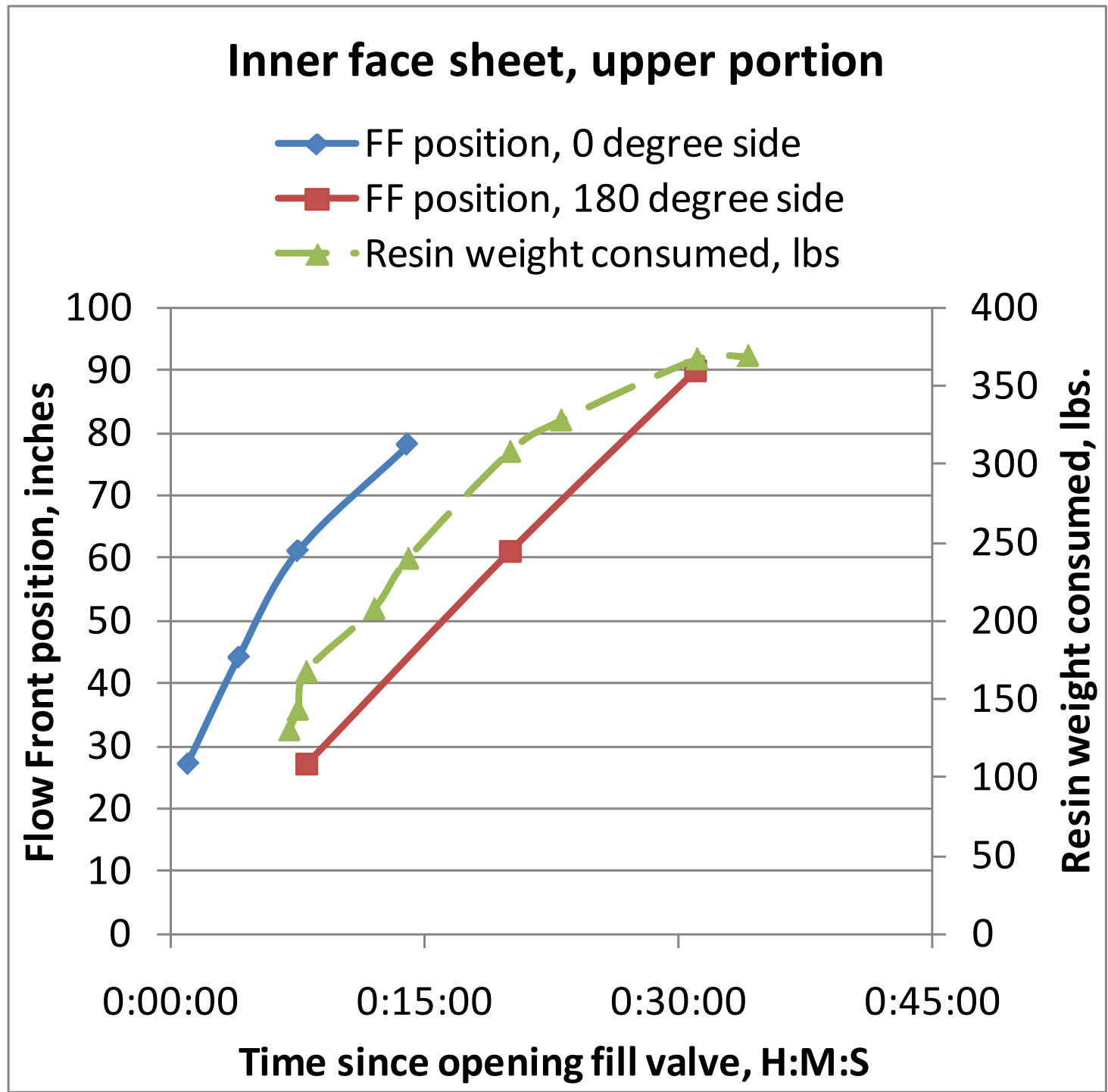

-Actual resin consumed (360 lb) agrees almost exactly with predicted (373 lb) -Rapid fill at 180 degrees (247 inches) away from RIL indicates that RURDL worked as planned 

temperature, compared to prediction

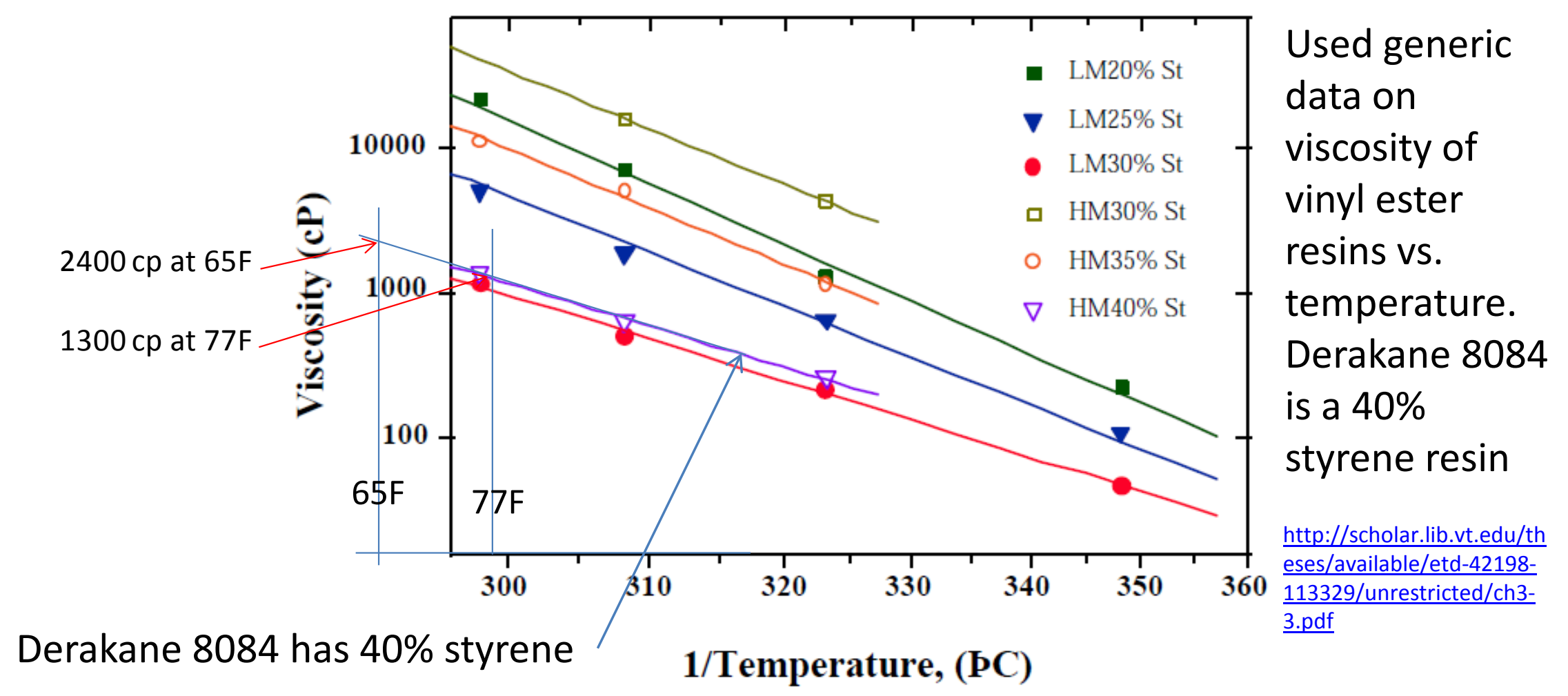

-Predicted fill time at 77F = 14 minutes (LMSSC VARTM model; panel data) -Fill time increase due to viscosity increase at 65F temperature $=2400 / 1300=1.85$ - Predicted fill time corrected to $65 \mathrm{~F}=1.85 \times 14=25.9$ minutes

-Actual fill time $=31$ minutes 

Stepwise infusion molding

\begin{tabular}{|c|c|c|}
\hline Component and operations & Results and key challenges met & Evidence \\
\hline $\begin{array}{l}\text { Vacuum testing of hard shells } \\
\text { (at Janicki) }\end{array}$ & $\begin{array}{l}\text { Successful - Achieved good vacuum in assembly after } \\
\text { welding quadrants together }\end{array}$ & Acceptance testing $\mathrm{COC}$ \\
\hline $\begin{array}{l}\text { Acceptance testing of basic } \\
\text { apparatus (at Janicki) }\end{array}$ & $\begin{array}{l}\text { Successful - Achieved good vacuum; operated RURDL's; } \\
\text { filled fully with pressurizing fluid (water) }\end{array}$ & Acceptance testing COC, photos, videos \\
\hline $\begin{array}{l}\text { Resin height monitoring system } \\
\text { (at LMSSC) }\end{array}$ & Successful-Can see resin through soft tools & $\begin{array}{l}\text { Photos and clips from 16-channel video } \\
\text { recorder }\end{array}$ \\
\hline Control system (at LMSSC) & $\begin{array}{l}\text { Successful - Operates all sub-systems from a central control } \\
\text { panel }\end{array}$ & $\begin{array}{l}\text { Notes within control system software } \\
\text { records }\end{array}$ \\
\hline $\begin{array}{l}\text { Resin supply, on-line mixing, } \\
\text { and resin feed system (at } \\
\text { LMSSC) }\end{array}$ & $\begin{array}{l}\text { Successful - Mixes and feeds large quantities without } \\
\text { exotherm }\end{array}$ & $\begin{array}{l}\text { Complete fill and cure of workpiece as } \\
\text { planned, negligible temperature rise in } \\
\text { curing workpiece }\end{array}$ \\
\hline $\begin{array}{l}\text { Functional test of RURDL and } \\
\text { RIL (at LMSSC) }\end{array}$ & $\begin{array}{l}\text { Successful - RURDL spreads resin circumferentially, then } \\
\text { collapses. RIL breaks off as planned. }\end{array}$ & $\begin{array}{l}\text { 2-step infusion filled as planned, leaving } \\
\text { negligible trace of excess cured resin on } \\
\text { workpiece }\end{array}$ \\
\hline $\begin{array}{l}\text { Pull good vacuum on } \\
\text { workpiece (at LMSSC) }\end{array}$ & $\begin{array}{l}\text { Successful - Double lower seals arrangement was } \\
\text { extremely effective in avoiding any air leakage past "cured } \\
\text { CWP" }\end{array}$ & $\begin{array}{l}\text { Vacuum gage readings at apparatus are } \\
\text { very close to supply vacuum }\end{array}$ \\
\hline $\begin{array}{l}\text { Infuse large workpiece (at } \\
\text { LMSSC) }\end{array}$ & $\begin{array}{l}\text { Successful - Infused about } 1000 \text { lbs. of resin in } 3 \text { "shots". } \\
\text { Got full wetout of fabric everywhere planned, in about } \\
\text { the planned time (correcting for temperature). Flow front } \\
\text { stopped at expected locations }\end{array}$ & $\begin{array}{l}\text { Overall visual inspection of workpiece. } \\
\text { Data on flow front position vs. time. }\end{array}$ \\
\hline $\begin{array}{l}\text { Cure shrinkage behavior of } \\
\text { large workpiece }\end{array}$ & $\begin{array}{l}\text { Successful - Inner face sheet stays in close contact with } \\
\text { core and does not pull away }\end{array}$ & Small cut-out samples \\
\hline $\begin{array}{l}\text { Stepwise infusion molding (at } \\
\text { LMSSC) }\end{array}$ & $\begin{array}{l}\text { Successful - "Knit-line" between infusion steps is not } \\
\text { discernable visually. }\end{array}$ & Knit-line cut-out sample \\
\hline
\end{tabular}




\section{Sidebar: Effects of axial forces on large seals}

\begin{tabular}{|c|c|c|c|}
\hline $\begin{array}{c}\text { Component } \\
\text { and operations }\end{array}$ & Results & Evidence and diagnosis & Future Needs \\
\hline \multicolumn{4}{|l|}{$\frac{3 . \text { Infusion }}{\underline{\text { molding }}}$} \\
\hline $\begin{array}{l}\text { Large inflatable } \\
\text { seals under } \\
\text { axial forces } \\
\text { from water } \\
\text { column and } \\
\text { vacuum (at } \\
\text { LMSSC) }\end{array}$ & $\begin{array}{l}\text {-Outer bottom } \\
\text { seal leaked while } \\
\text { filling with water } \\
\text { to the top (before } \\
\text { second step of } \\
\text { inner stepwise } \\
\text { infusion). } \\
\text { It had held just } \\
\text { fine during first } \\
\text { step, which was to } \\
\text { a lower water } \\
\text { elevation. } \\
\text { It had held just } \\
\text { fine during Janicki } \\
\text { acceptance } \\
\text { testing. } \\
\text {-Outer RURDL } \\
\text { disbonded from } \\
\text { outer soft tool. }\end{array}$ & $\begin{array}{l}\text { Outer seals flipped out of position axially, causing major } \\
\text { water leakage. Both outer bottom seals were "flipped" over } \\
\text { about } 90 \text { degrees of arc. Outer RURDL disbonded from outer } \\
\text { soft tool. } \\
\text { LMSSC preliminary diagnosis (concurred with by Janicki) is } \\
\text { that outer soft tool slipped downward on the RDM of the } \\
\text { workpiece under the large axial forces induced by the water } \\
\text { column, in a way that did not happen during acceptance } \\
\text { testing at Janicki because during that test, the soft tools were } \\
\text { pressing directly on the foam test core, not the more slippery } \\
\text { RDM. } \\
\text { Downward slippage of the outer soft tool tore it from the } \\
\text { outer RURDL, which was supported by straps from the outer } \\
\text { hard shell. } \\
\text { Upper "centering ring" seals, also under axial forces because } \\
\text { of } 1 \text { atm vacuum pressure differential across them, did not } \\
\text { flip out because of foam blocks inserted above them to } \\
\text { protect against such an event. (Note: One upper seal had } \\
\text { flipped out at Janicki before foam blocks were inserted.) }\end{array}$ & $\begin{array}{l}\text { Janicki and LMSCC convened a } \\
\text { telecon including all individuals } \\
\text { familiar with the work. All agreed } \\
\text { that the root cause was the } \\
\text { instability in the large inflatable } \\
\text { seals under strong axial forces, } \\
\text { and that an improvement was } \\
\text { needed to stabilize them. } \\
\text { Two possibilities were identified, } \\
\text { both designed to prevent axial } \\
\text { movement of their non-anchored } \\
\text { sides: } \\
\text { a. Add diagonal straps over } \\
\text { seals, connected to hard } \\
\text { shells } \\
\text { b. Mold } 2^{\text {nd }- \text { generation axial }} \\
\text { seals to a triangular shape }\end{array}$ \\
\hline
\end{tabular}

Despite this fairly major failure of one mechanical element of the apparatus, we were able to recover and complete the molding region validation. The inner soft tool and inner RURDL were undamaged, and we validated the RURDL behavior and stepwise infusion process on the inner face sheet. To complete the outer face sheet molding validation, we installed an ad-hoc disposable RDL consisting of several turns of standard "spiral-wrap" RDL, with some extra spiral wrap at the RIL to form a large open interface. Infusion of the outer face sheet was then successful. 


\section{Path forward}

The next figure summarizes the overall CWP roadmap in terms of past and recently completed steps, and future planned steps. 


\section{OTEC LM OTEC CWP development and implementation roadmap}

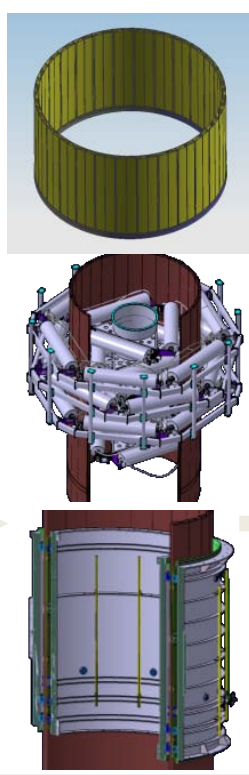

\section{CWP Trade study}

Complete

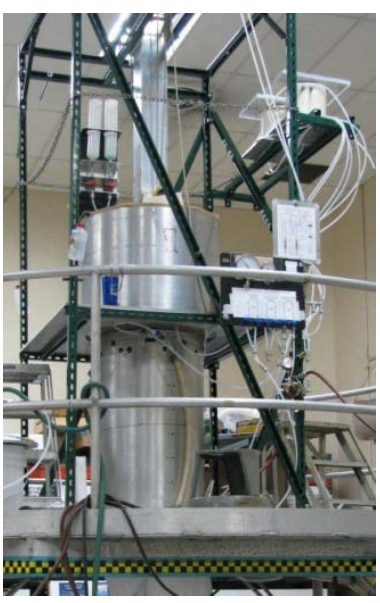

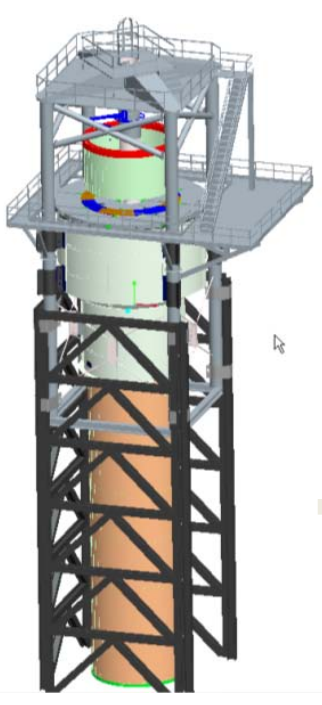

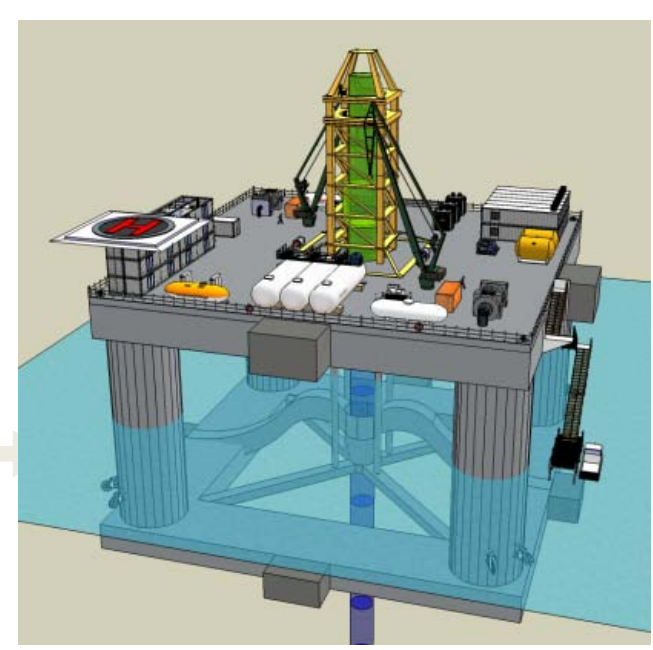

\begin{tabular}{|c|c|c|c|c|c|}
\hline complete & Complete & & & & \\
\hline Jan-May 2008 & June-Dec. 2008 & Jan 2009 to Dec. 2010 & TBD & TBD & TBD \\
\hline $\begin{array}{l}\text { Activity: Select } \\
\text {-Material } \\
\text {-Configuration } \\
\text {-Fabrication process }\end{array}$ & $\begin{array}{l}\text {-Small-scale (18" } \\
\text { ID) validation of } \\
\text { fabrication process }\end{array}$ & $\begin{array}{l}\text { - Large-scale (4m ID) } \\
\text { validation of critical } \\
\text { elements } \\
\text {-Complete }\end{array}$ & $\begin{array}{l}\text {-Large-scale } \\
\text { validation of } \\
\text { integrated process } \\
\text {-Collect recurring } \\
\text { labor cost data }\end{array}$ & $\begin{array}{l}\cdot 1000 m \text { CWP } \\
\text { attached to } \\
\text { TBD platform }\end{array}$ & $\begin{array}{l}\cdot 1000 m \text { CWP } \\
\text { attached to } 100 \\
\text { MW platform }\end{array}$ \\
\hline $\begin{array}{l}\text { Basis and size: } \\
10 \mathrm{~m} \text { ID } \times 1000 \mathrm{~m} \text { long } \\
\text { CWP for } 100 \mathrm{MW}\end{array}$ & $\begin{array}{l}0.5 \mathrm{~m} \text { ID x 34" per } \\
\text { step }\end{array}$ & $4 \mathrm{~m} \mathrm{ID} \times 7.5 \mathrm{ft}$ per step & $\begin{array}{l}4 \mathrm{~m} \text { ID } \times 19 \mathrm{ft} \text { per } \\
\text { step, } 3 \text { or more } \\
\text { successive steps }\end{array}$ & $\begin{array}{l}4 \mathrm{~m} \text { ID } \times 19 \text { or } \\
39 \mathrm{ft} . \text { per step }\end{array}$ & $\begin{array}{l}10 \mathrm{~m} \text { ID } \times 19 \text { or } \\
39 \mathrm{ft} . \text { per step }\end{array}$ \\
\hline $\begin{array}{l}\text { Location: LMSSC-ATC } \\
\text { and Sunnyvale }\end{array}$ & $\begin{array}{l}\text { LMSSC-ATC and } \\
\text { Sunnyvale }\end{array}$ & $\begin{array}{l}\text { LMSSC Sunnyvale } \\
\text { B/132 }\end{array}$ & TBD & Hawaii & Hawaii \\
\hline $\begin{array}{l}\text { Funding: } \\
\text { MS2 LTTI IRAD }\end{array}$ & MS2 LTTI IRAD & $\begin{array}{l}\text { AWPP-DoE/MS2 } \\
\text { CRADA copyright Locl }\end{array}$ & $\begin{array}{c}\text { TBD } \\
\text { ed Martin Corporation } 2011\end{array}$ & TBD & $\begin{array}{l}\text { Commercial }_{152} \\
\text { project }\end{array}$ \\
\hline
\end{tabular}




\section{Executive Summary}

Critical elements of the LM OTEC CWP design and

fabrication apparatus and process have been validated at a $4 \mathrm{~m}$ diameter scale. These elements include:

- Core plank production and assembly into core rings -Fabric architecture, fabric dispensing, and overlap splice performance -Stepwise infusion molding

The following slides summarize the major results and conclusions, at the level of one photo montage and one table per validation element. 


\section{OIEC Pictorial summary of LM Advanced Composite Cold Water Pipe Approach}

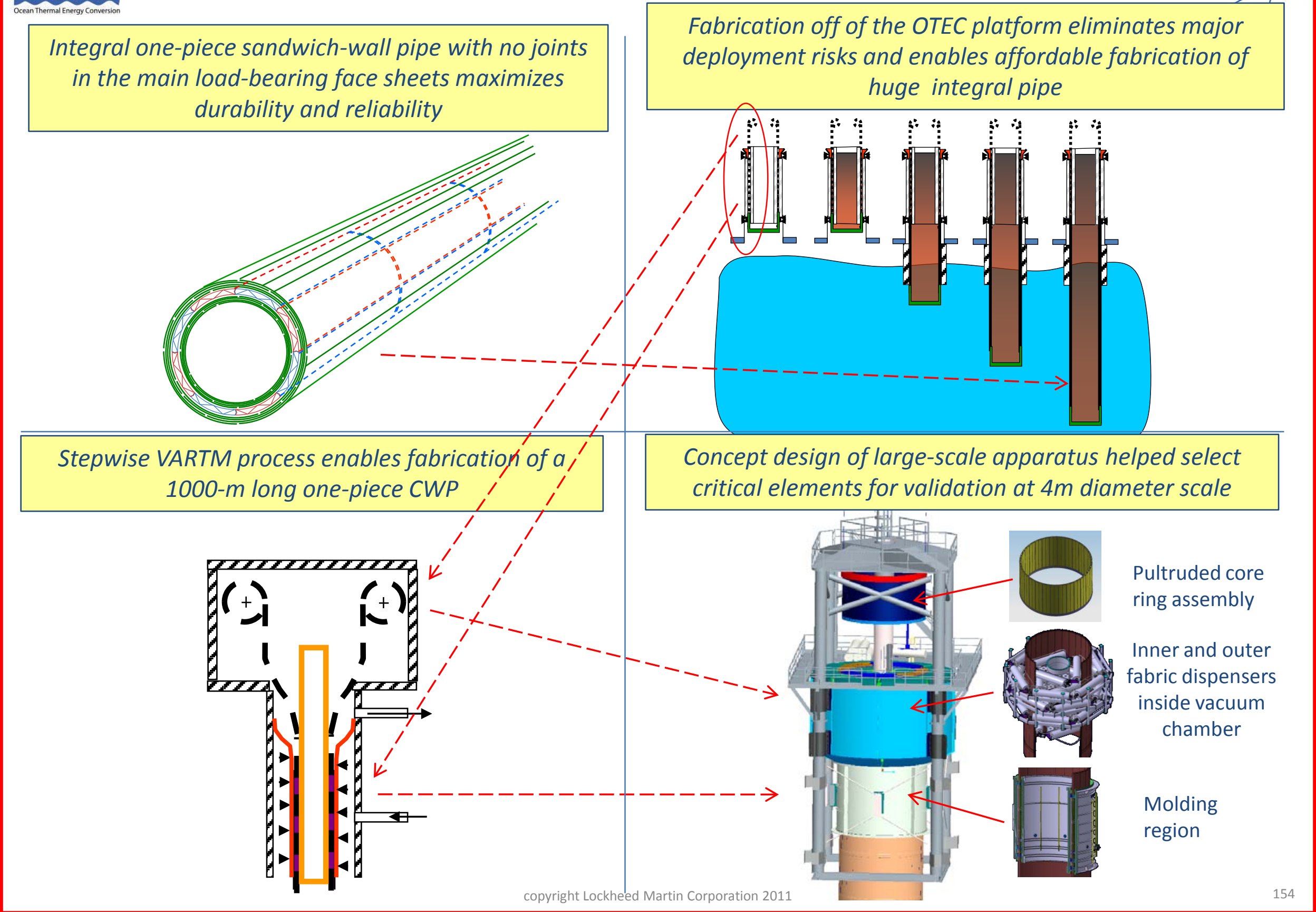




\section{OJEC}
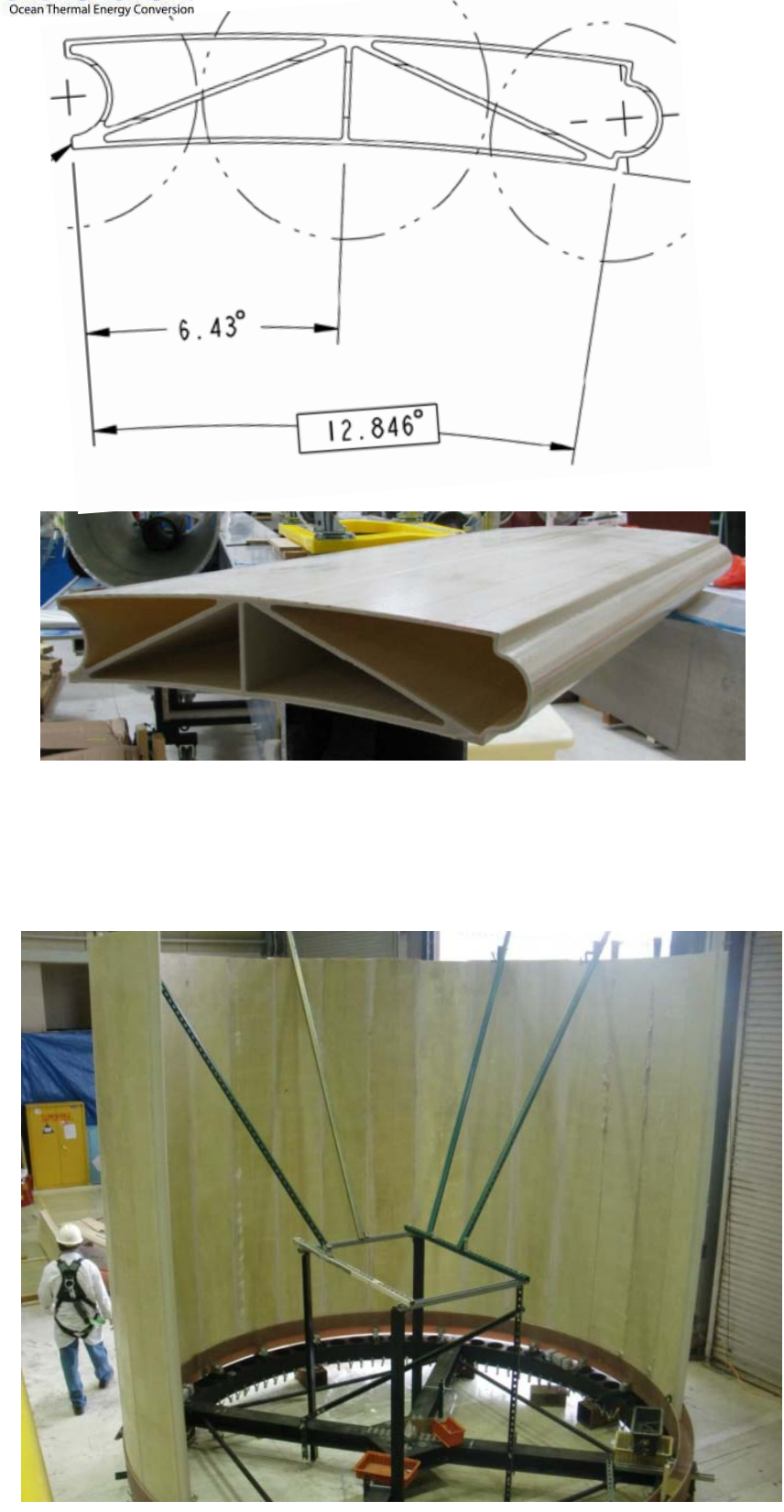
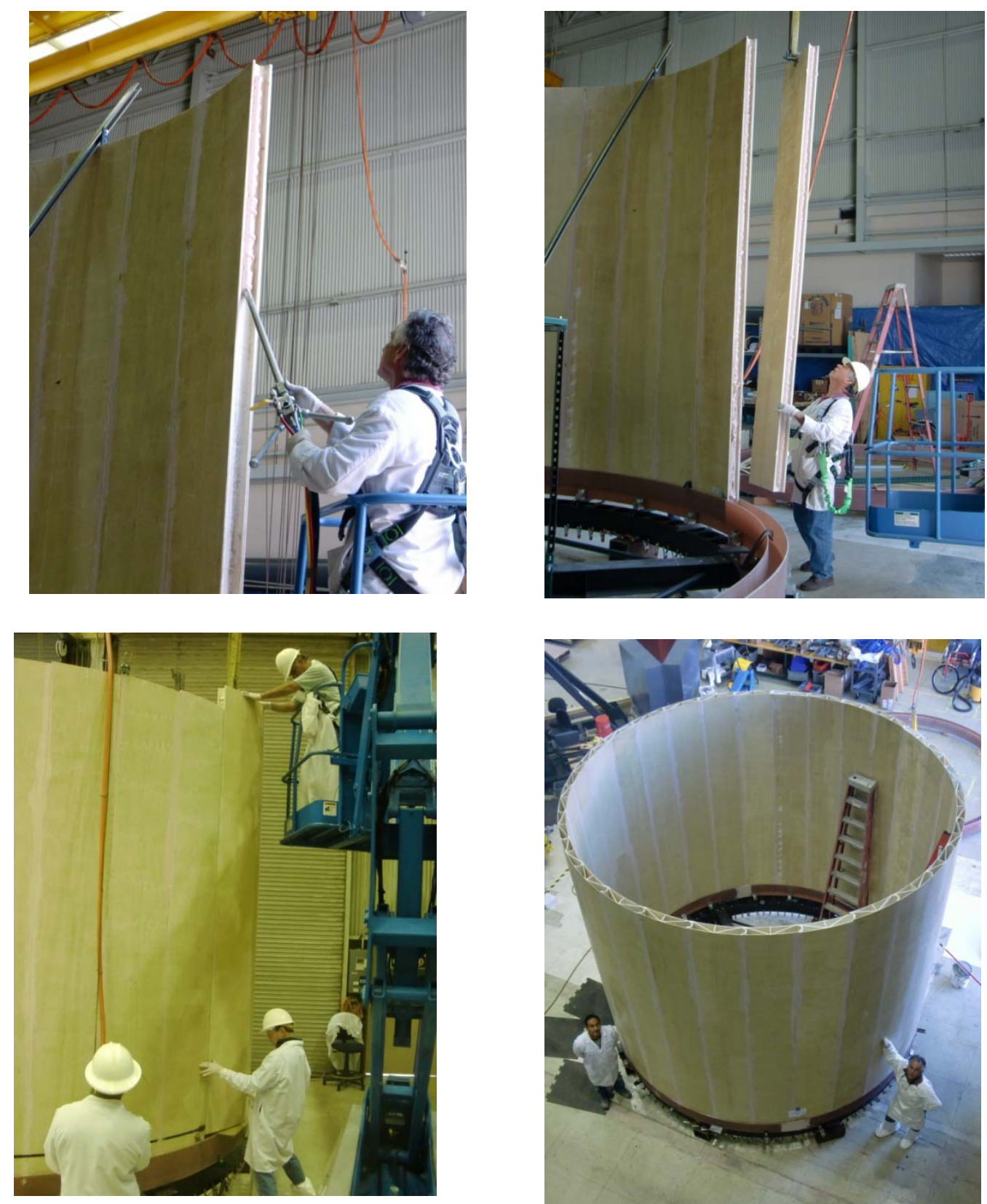

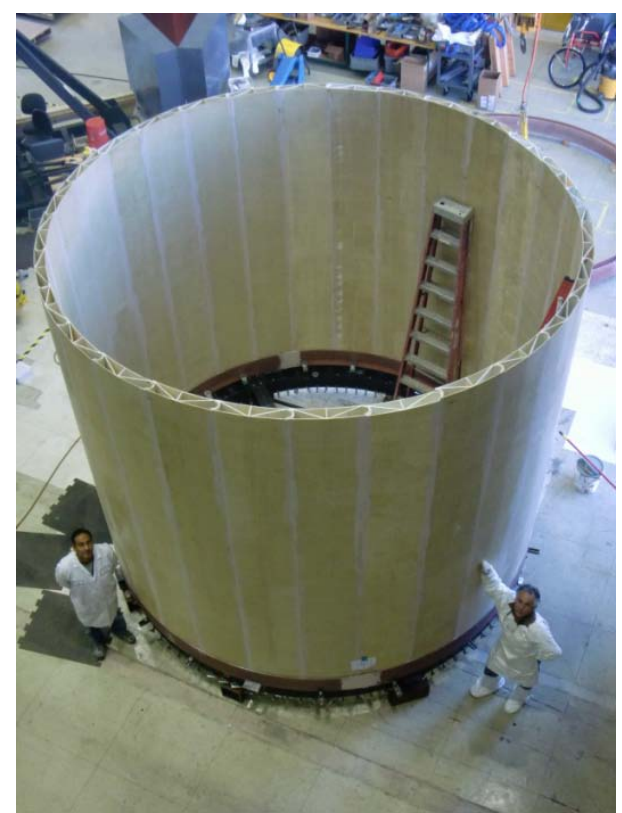




\section{Tabular summary of validation results at $4 \mathrm{~m}$ scale - Core production and assembly}

\begin{tabular}{|c|c|c|c|}
\hline Component and operations & Results and key challenges met & Evidence & Future Needs \\
\hline $\begin{array}{l}\text { Produce custom pultrusions } \\
\text { designed to meet all initially known } \\
\text { loads, and meeting requirements of } \\
\text { stepwise infusion fabrication } \\
\text { process (at Glasforms) }\end{array}$ & $\begin{array}{l}\text { Successful - Achieved proper } \\
\text { fabric guidance, resin wet-out, } \\
\text { and straightness in complex } \\
\text { multi-cell hollow pultruded } \\
\text { shape made from all-fabric with } \\
\text { some sparse fiber directions }\end{array}$ & $\begin{array}{l}\text { Pultruded planks; good fit-up } \\
\text { and dimensional control in } \\
\text { assembled core ring }\end{array}$ & $\begin{array}{l}\text { For fabrication of long } \\
\text { CWP on-the-water, need } \\
\text { to add more ribs to } \\
\text { increase local buckling } \\
\text { strength under pressure of } \\
\text { gripper and bushings }\end{array}$ \\
\hline $\begin{array}{l}\text { Bond pultruded planks into core } \\
\text { ring }\end{array}$ & $\begin{array}{l}\text { Successful - Achieved proper } \\
\text { spacing to fit shear keys. } \\
\text { Achieved good circularity and } \\
\text { diameter control }\end{array}$ & $\begin{array}{l}\text { Results at multiple locations: } \\
+/-1 / 8^{\prime \prime} \text { variability in } \\
\text { diameter over the } 158^{\prime \prime} \\
\text { diameter }\end{array}$ & \\
\hline $\begin{array}{l}\text { Test vacuum tightness of as- } \\
\text { received pultruded planks }\end{array}$ & $\begin{array}{l}\text { Not successful - A random } \\
\text { sample core plank was vacuum } \\
\text { bagged on its outside. Drop } \\
\text { testing showed a 6" Hg drop in } \\
5 \text { minutes. }\end{array}$ & $\begin{array}{l}\text { This was despite the plank } \\
\text { manufacturer's water-tank } \\
\text { testing of best and worst } \\
\text { planks, with application of } \\
\text { resin on the outside of all to } \\
\text { seal them. }\end{array}$ & $\begin{array}{l}\text { Need to improve the leak- } \\
\text { tightness of the core } \\
\text { planks as-pultruded, or if } \\
\text { necessary with } \\
\text { subsequent sealing }\end{array}$ \\
\hline $\begin{array}{l}\text { Test vacuum tightness of plank-to- } \\
\text { plank joints (staggered planks } \\
\text { approach) }\end{array}$ & $\begin{array}{l}\text { Successful - The assembly leak } \\
\text { tightness is as good as the } \\
\text { planks themselves }\end{array}$ & $\begin{array}{l}\text { Same vacuum drop as the } \\
\text { planks themselves. No } \\
\text { audible evidence of air } \\
\text { leakage at longitudinal joints }\end{array}$ & \\
\hline $\begin{array}{l}\text { Produce leak-tight core assembly } \\
\text { by pre-applying a commercial "slosh } \\
\text { sealing compound" inside each cell } \\
\text { of each plank, then assemble into } \\
\text { staggered-planks configuration, and } \\
\text { vacuum test }\end{array}$ & $\begin{array}{l}\text { Successful - Overall drop-test } \\
\text { leak rate of staggered-joint } \\
\text { assembly is close to acceptable } \\
\text { level for VARTM tools. }\end{array}$ & $\begin{array}{l}\text { 6" Hg vacuum drop in } 5 \\
\text { minutes }\end{array}$ & $\begin{array}{l}\text { Improve the leak-tightness } \\
\text { of the core planks as- } \\
\text { pultruded, and use slosh } \\
\text { compound as a re-work } \\
\text { measure if necessary to } \\
\text { ensure leak-free } \\
\text { pultrusions. }\end{array}$ \\
\hline
\end{tabular}




\section{OJEC \\ Pictorial summary of Fabric Dispensing validation}

Function: Fabric is dispensed by machine under constant tension maintained by servomotor-driven rollers, and is guided by special "bibs" into its curved configuration.

Machine-based fabric placement eliminates hand layup labor and is the key to low recurring costs. Status: Validation proved that the apparatus forms consistent overlap splices, well within required tolerances.

Outer face sheets

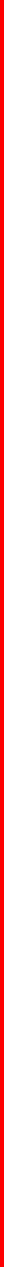



Fabric architecture and dispensing

\begin{tabular}{|l|l|l|l|}
\hline Component and operations & Results and key challenges met & \multicolumn{1}{|c|}{ Evidence } & Future Needs \\
\hline Overlap splices in face sheets & $\begin{array}{l}\text { Successful - Splice regions are as } \\
\text { strong as the base laminate }\end{array}$ & $\begin{array}{l}\text { Local buckling } \\
\text { specimen failed } \\
\text { away from the } \\
\text { splices }\end{array}$ & \\
\hline $\begin{array}{l}\text { Design and construct complex } \\
\text { apparatus (w. Janicki) }\end{array}$ & Successful & Apparatus & $\begin{array}{l}\text { Core chucks which do not require periodic } \\
\text { re-charging with air pressure }\end{array}$ \\
\hline $\begin{array}{l}\text { Acceptance testing of } \\
\text { apparatus (at Janicki) }\end{array}$ & $\begin{array}{l}\text { Successful - Maintained constant } \\
\text { payout tension despite } \\
\text { variations in "demand" payout } \\
\text { velocity imposed at free end of } \\
\text { fabric }\end{array}$ & $\begin{array}{l}\text { Acceptance } \\
\text { testing COC, } \\
\text { photos, videos }\end{array}$ & \\
\hline $\begin{array}{l}\text { Validate fabric dispensing } \\
\text { operations (at Janicki) }\end{array}$ & $\begin{array}{l}\text { Successful - Variations in width } \\
\text { of fabric overlap are well below } \\
\text { allowable }\end{array}$ & $\begin{array}{l}\text { Validation } \\
\text { testing report, } \\
\text { photos, videos }\end{array}$ & \\
\hline
\end{tabular}




\section{OYEC Pictorial summary of stepwise infusion molding validation}
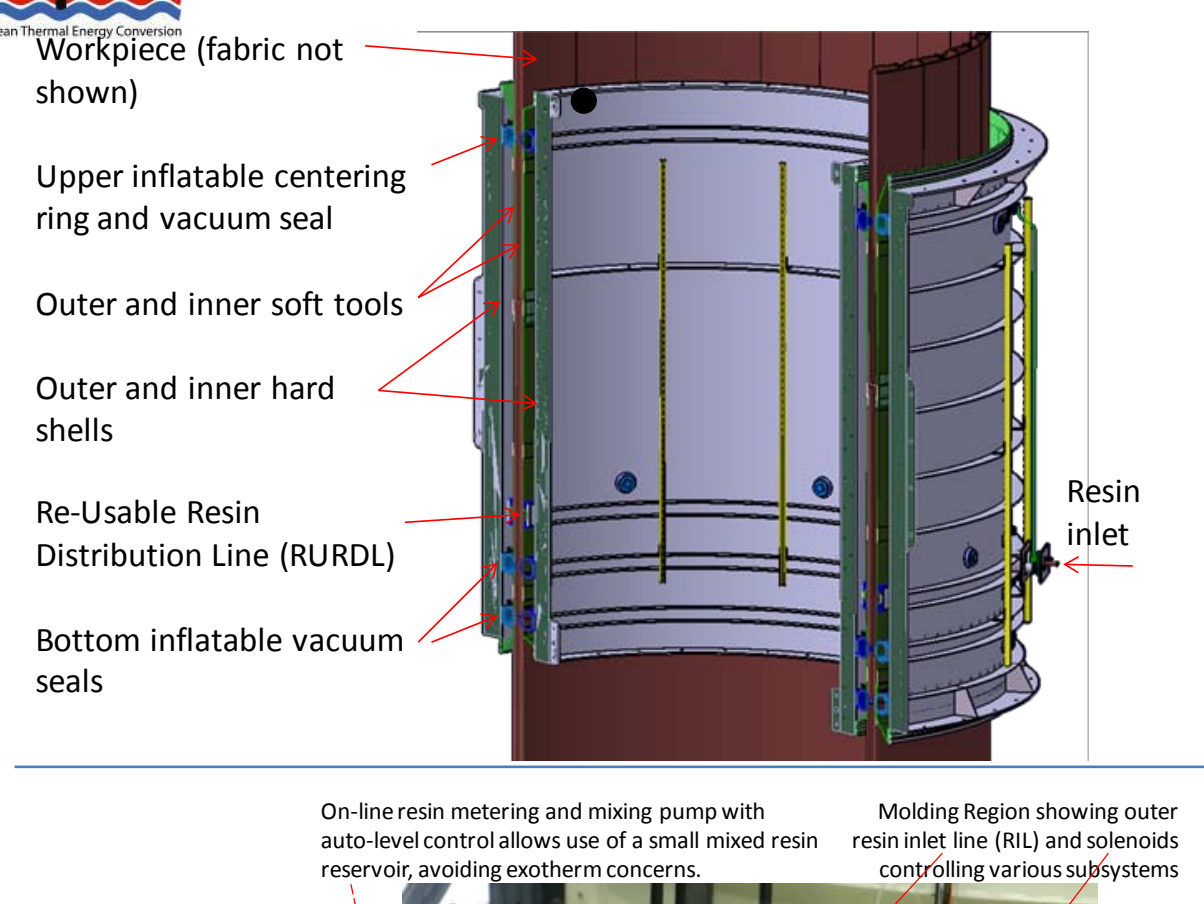

\section{Infusion of workpiece}

-About $1000 \mathrm{lbs}$. of resin was mixed and infused in 3 shots

-The fill time was within about $20 \%$ of predicted (after correcting the resin viscosity to the low temperatures in the unheated High-Bay)

-The specialized apparatus enablesinfusion to be done by a 2-person crew

On-line resin metering and mixing pump with Molding Region showing outer reservoir, avoiding exotherm concerns. controlling various subsystem

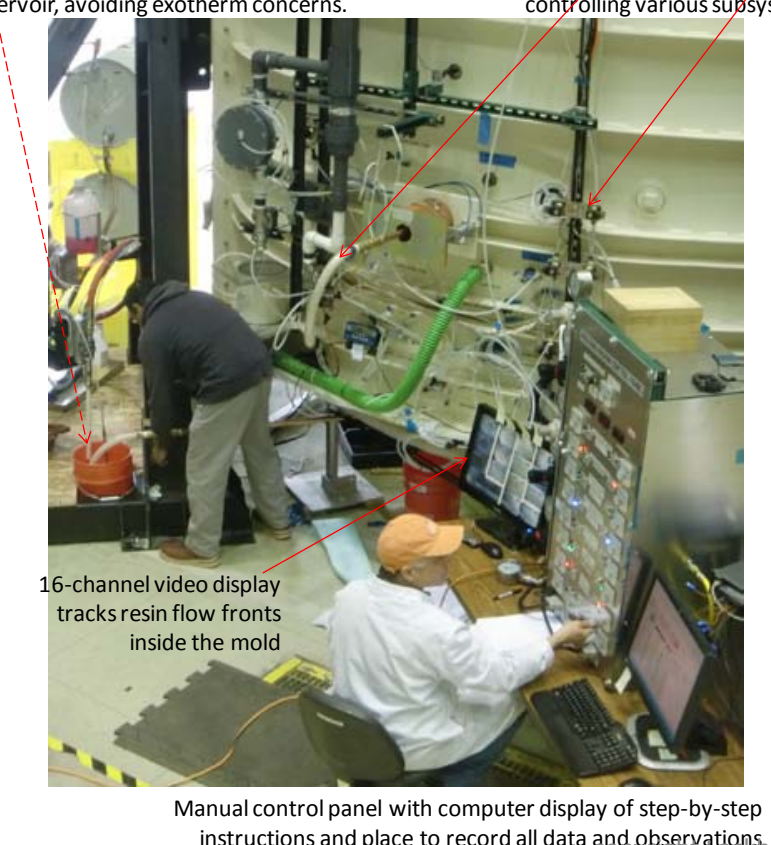

Inner and outer soft tools and upper seals

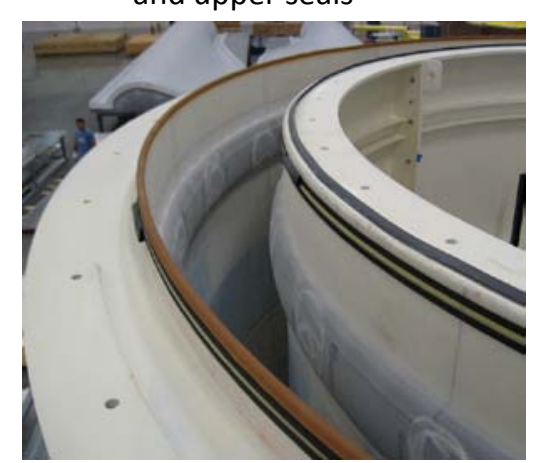

Removing infused and cured workpiece from mold
Hanging outer face sheet fabric on test core

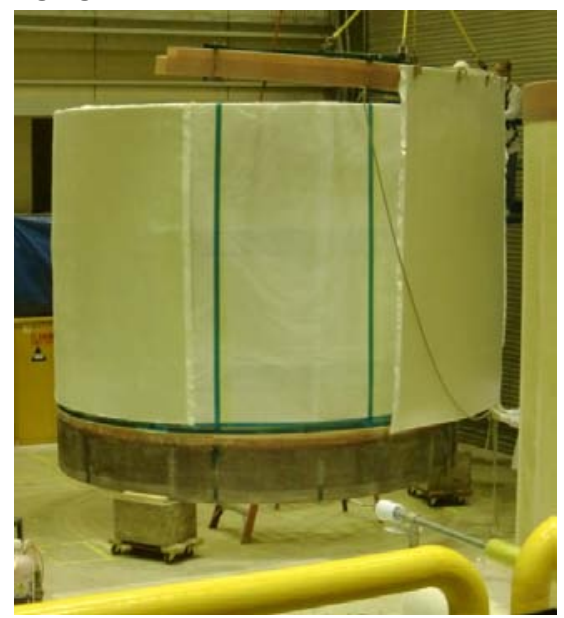

Key result: The knit-line between infusion steps is indistinguishable from the base laminate. The stepwise infusion process is validated!

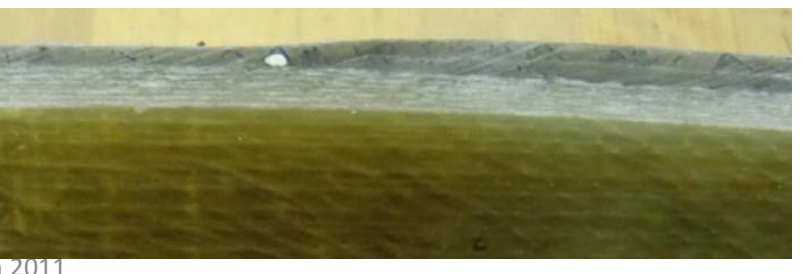



Stepwise infusion molding

\begin{tabular}{|c|c|c|}
\hline Component and operations & Results and key challenges met & Evidence \\
\hline $\begin{array}{l}\text { Vacuum testing of hard shells } \\
\text { (at Janicki) }\end{array}$ & $\begin{array}{l}\text { Successful - Achieved good vacuum in assembly after } \\
\text { welding quadrants together }\end{array}$ & Acceptance testing $\mathrm{COC}$ \\
\hline $\begin{array}{l}\text { Acceptance testing of basic } \\
\text { apparatus (at Janicki) }\end{array}$ & $\begin{array}{l}\text { Successful - Achieved good vacuum; operated RURDL's; } \\
\text { filled fully with pressurizing fluid (water) }\end{array}$ & Acceptance testing COC, photos, videos \\
\hline $\begin{array}{l}\text { Resin height monitoring system } \\
\text { (at LMSSC) }\end{array}$ & Successful-Can see resin through soft tools & $\begin{array}{l}\text { Photos and clips from 16-channel video } \\
\text { recorder }\end{array}$ \\
\hline Control system (at LMSSC) & $\begin{array}{l}\text { Successful - Operates all sub-systems from a central control } \\
\text { panel }\end{array}$ & $\begin{array}{l}\text { Notes within control system software } \\
\text { records }\end{array}$ \\
\hline $\begin{array}{l}\text { Resin supply, on-line mixing, } \\
\text { and resin feed system (at } \\
\text { LMSSC) }\end{array}$ & $\begin{array}{l}\text { Successful - Mixes and feeds large quantities without } \\
\text { exotherm }\end{array}$ & $\begin{array}{l}\text { Complete fill and cure of workpiece as } \\
\text { planned, negligible temperature rise in } \\
\text { curing workpiece }\end{array}$ \\
\hline $\begin{array}{l}\text { Functional test of RURDL and } \\
\text { RIL (at LMSSC) }\end{array}$ & $\begin{array}{l}\text { Successful - RURDL spreads resin circumferentially, then } \\
\text { collapses. RIL breaks off as planned. }\end{array}$ & $\begin{array}{l}\text { 2-step infusion filled as planned, leaving } \\
\text { negligible trace of excess cured resin on } \\
\text { workpiece }\end{array}$ \\
\hline $\begin{array}{l}\text { Pull good vacuum on } \\
\text { workpiece (at LMSSC) }\end{array}$ & $\begin{array}{l}\text { Successful - Double lower seals arrangement was } \\
\text { extremely effective in avoiding any air leakage past "cured } \\
\text { CWP" }\end{array}$ & $\begin{array}{l}\text { Vacuum gage readings at apparatus are } \\
\text { very close to supply vacuum }\end{array}$ \\
\hline $\begin{array}{l}\text { Infuse large workpiece (at } \\
\text { LMSSC) }\end{array}$ & $\begin{array}{l}\text { Successful - Infused about } 1000 \text { lbs. of resin in } 3 \text { "shots". } \\
\text { Got full wetout of fabric everywhere planned, in about } \\
\text { the planned time (correcting for temperature). Flow front } \\
\text { stopped at expected locations }\end{array}$ & $\begin{array}{l}\text { Overall visual inspection of workpiece. } \\
\text { Data on flow front position vs. time. }\end{array}$ \\
\hline $\begin{array}{l}\text { Cure shrinkage behavior of } \\
\text { large workpiece }\end{array}$ & $\begin{array}{l}\text { Successful - Inner face sheet stays in close contact with } \\
\text { core and does not pull away }\end{array}$ & Small cut-out samples \\
\hline $\begin{array}{l}\text { Stepwise infusion molding (at } \\
\text { LMSSC) }\end{array}$ & $\begin{array}{l}\text { Successful - "Knit-line" between infusion steps is not } \\
\text { discernable visually. }\end{array}$ & Knit-line cut-out sample \\
\hline
\end{tabular}

